UNIVERSIDADE DE SÃO PAULO

FACULDADE DE FILOSOFIA, LETRAS E CIÊNCIAS HUMANAS DEPARTAMENTO DE GEOGRAFIA

VILMA APARECIDA DA SILVA

A campesinidade presente na construção do espaço geográfico da cidade de Cubatão

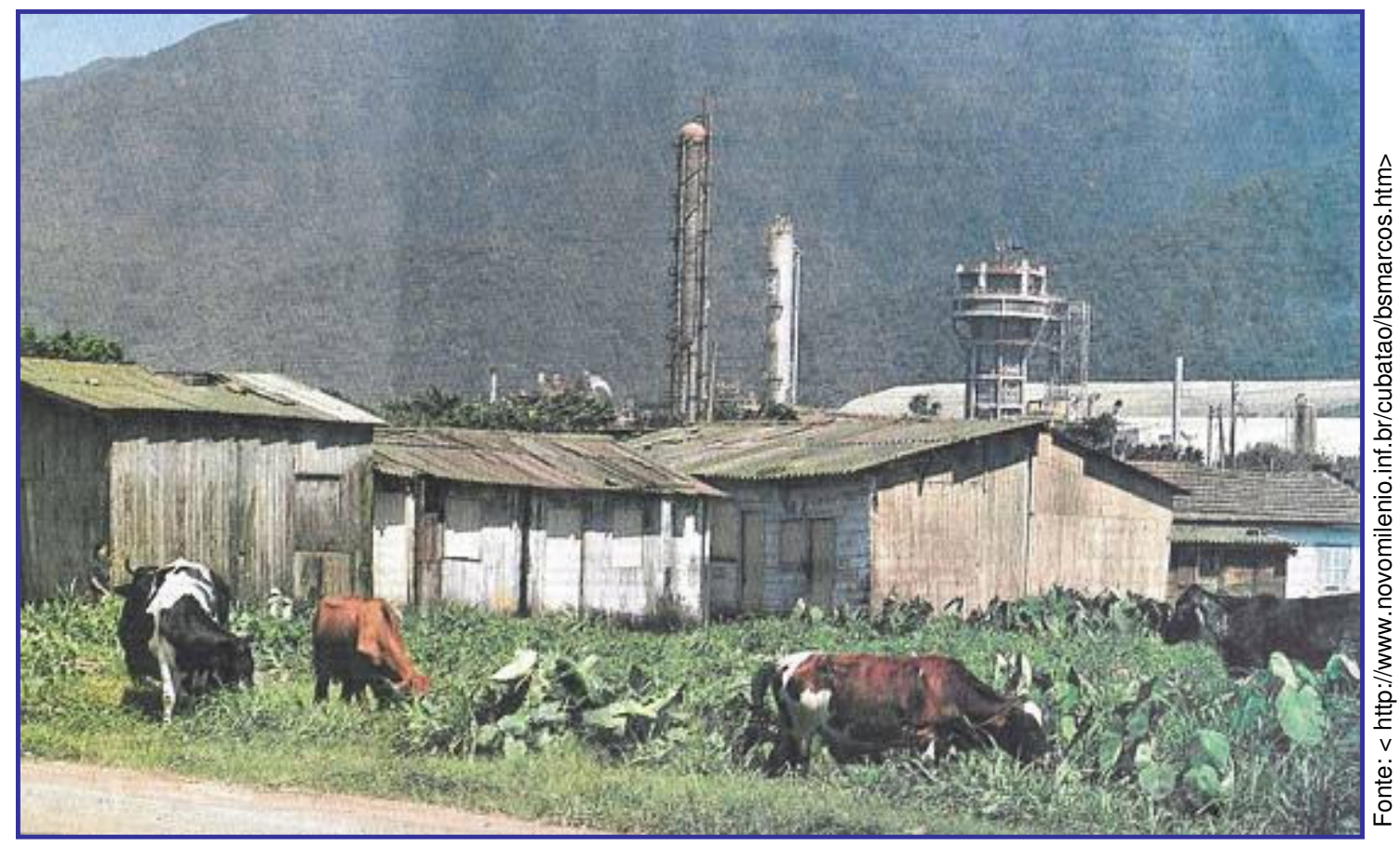

São Paulo 


\title{
A campesinidade presente na construção do espaço geográfico da cidade de Cubatão
}

\author{
Dissertação apresentada ao Departamento de Geografia da \\ Faculdade de Filosofia Letras e Ciências Humanas da \\ Universidade de São Paulo para obtenção do título de Mestre \\ em Geografia Humana. \\ Área de Concentração: Geografia Humana \\ Orientadora: Profa. Dra. Marta Inez Medeiros Marques
}

São Paulo 


\section{Vilma Aparecida da Silva}

\section{A campesinidade presente na construção do espaço geográfico da cidade de Cubatão}

Dissertação apresentada ao Departamento de Geografia da Faculdade de Filosofia Letras e Ciências Humanas da Universidade de São Paulo para obtenção do título de Mestre em Geografia Humana.

Área de Concentração: Geografia Humana

Aprovado em:

Banca Examinadora

Prof. Dr.

Instituição:

Assinatura:

Prof. Dr.

Instituição:

Assinatura:

Prof. Dr.

Instituição:

Assinatura:

Prof. Dr.

Instituição:

Assinatura:

Prof. Dr.

Instituição:

Assinatura: 
A Deus e a Virgem Maria, pelo dom da vida e pela fé; Ao José Maurício, pelo amor, incentivo e apoio; Ao Vanderson, meu irmão e companheiro; A Antônio e Erci, meus queridos pais pelo amor verdadeiro e por me apresentarem ao modo de vida camponês. 


\section{Agradecimentos}

Gostaria de expressar minha gratidão a todas as pessoas que contribuíram para a realização desse trabalho.

A todos os migrantes que sacrificaram tantas coisas para viver em Cubatão.

A todos os meus entrevistados, pela partilha de momentos de suas vidas, pela confiança em mim depositada e solicitude com que prestaram seus depoimentos.

A todos aqueles que com suas orações e incentivo me deram força na caminhada. Em especial à minha grande amiga Sueli Solange Pereira, à Vera Archanjo, à Rosana Garzi, Rosânia Araújo, Dona Fabíola, Cátia Pereira, Alexandra Oliveira e Raildo.

Aos meus amigos que com sinceridade e amor souberam me ajudar com tantas questões...

A Ariovaldo Umbelino de Oliveira, por saber compartilhar sua sabedoria. Minha admiração.

Aos professores José de Souza Martins, Heinz Dieter Heidemann, Ana Fani e Júlio Suzuki.

Às funcionárias da Secretaria de Pós-Graduação da USP, pelo carinho e solicitude.

À Marilene pelas discussões e colaborações.

Ao Marcos, à Carina Bernini, à Flavia, Pedro, Júlia, Herbert e Aderbau Gama.

Aos colegas do Laboratório de Geografia Agrária da USP.

Aos funcionários da Prefeitura Municipal de Cubatão, do Arquivo Histórico, do Corpo de Bombeiros, da Polícia Militar de Cubatão e da Casa Brasil.

À família do José Maurício pelo incentivo e carinho.

À Pró-Reitoria de Pesquisa da Universidade de São Paulo pela concessão de bolsa de mestrado pelo período de seis meses. 
Ao CNPq (Conselho Nacional de Desenvolvimento Científico e Tecnológico) pela bolsa de mestrado concedida, que possibilitou a realização desse trabalho.

À professora Marta Inez Medeiros Marques pela orientação dedicada e competente. Agradeço sua paciência e sinceridade. 


\section{Resumo}

O presente estudo tem o objetivo de analisar a ampla ocorrência de práticas rurais na cidade de Cubatão atualmente. Para tanto, considera o processo de urbanização dessa cidade, iniciado com a industrialização. Nesse sentido, o conceito de campesinidade de Woortmann (1990) assume importância central para a análise do contexto cultural que envolve a realização dessas práticas e o significado que elas apresentam para os sujeitos sociais nelas envolvidos. Cubatão se destacou por muitos anos como local estratégico de ligação entre o planalto e o litoral (Baixada Santista), exercendo a função de porto e posto fiscal. Com a instalação de colonos açorianos em suas terras em 1803, deu-se início a algumas atividades agrícolas no município. A partir da instalação da Estrada de Ferro Santos-Jundiaí, as atividades comerciais entraram em declínio e Cubatão passou a se dedicar à cultura da banana - que se tornou uma importante atividade econômica até 1950, quando a cidade se tornou industrial. A produção agrícola foi drasticamente reduzida, ao passo que a indústria passou a atrair uma grande massa de trabalhadores migrantes, sendo muitos provenientes do campo. O tipo de urbanização advinda dessa industrialização produziu um espaço fragmentado, em sua maioria composto por favelas. A partir da realização de atividades agrícolas, a espacialização do migrante de raiz camponesa revela uma tentativa de apropriação do espaço através da lógica do uso. No entanto, essa prática é atravessada pela racionalidade do capital, através da ação estatal. Esse embate é vivenciado pelo migrante no plano do vivido, onde as insurgências do uso se impõem como o irredutível, não sucumbindo à opressão da equivalência; ou seja, as atividades realizadas por esse sujeito social são praticadas independente de serem permitidas, toleradas, proibidas ou negadas. Dessa forma, a cidade expõe suas contradições relativas à sua forma e seu conteúdo.

Palavras-chaves: Campesinidade; Agricultura Urbana; Urbanização; Proletarização; Migração. 


\section{Abstract}

The aim of this study is to analyse the widespread incidence of rural practices that currently take place in the city of Cubatão. For this purpose, it considers the city's urbanization process, which began following the industrialization process. In this context, Woortmann's concept of peasant moral order (1990) assumes central importance in the analysis of the cultural context involving the accomplishment of these practices and its significance given by the social actors involved. For many years, due to its strategic localization, Cubatão played a relevant role in linking the plateau and the coastline (Baixada Santista), operating as a port and fiscal site. With the settlement of Azorean colonists in its land, in 1803, agriculture was introduced in the city. After the Santos-Jundiai Railway was built, commerce declined and Cubatão started concentrating on the culture of banana - which became an important economic activity up to 1950 , when the city became industrial. The agricultural production was then drastically reduced at the same time that the industry began to attract a great mass of migrant workers, constituted mainly by peasant individuals. The type of urbanization created by the industrialization process produced a fragmented space, formed in majority by slums quarters. As a result of rural practices, the spacialization of the migrant from a peasant background, discloses an attempt of spacialization through the logic of the use. However, these practices are crossed by the rationality of the capital, supported by State action. This conflict is experienced by the migrant in the realm of the lived, where the insurgencies of the use impose themselves as the irreducible, not succumbing to the oppression of equivalence; that is, the activities carried out by this social actor are practised independently of being allowed, tolerated, forbidden or denied. In this way, the city displays its contradictions relating to its form and content.

Key-words: Peasant moral order; Urban Agriculture; Urbanization; Proletarization; Migration. 


\section{Sumário}

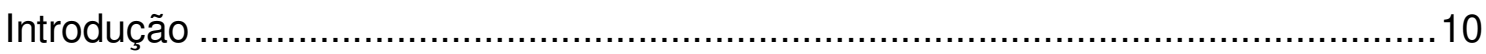

Capítulo 1. Da condição de Porto à Cidade Industrial .............................................19

$1.1 \mathrm{O}$ caminho de ligação com o Planalto …………............................................19

$1.2 \mathrm{O}$ início do povoamento e o desenvolvimento da agricultura...........................25

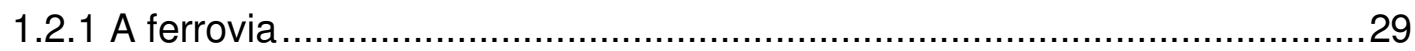

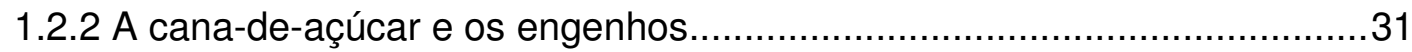

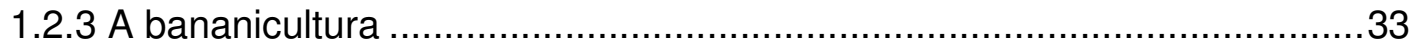

1.3 As primeiras indústrias e as Vilas Operárias …………………………......... 42

1.3.1 Companhia Curtidora Marx e a Vila Colônia ………………………........4

1.3.2. Companhia J. B. Duarte e a Vila Química ............................................46

1.3.3 Companhia Fabril de Cubatão e a Vila Fabril.........................................49

1.3.4 Usina Henry Borden e a Vila Light ....................................................52

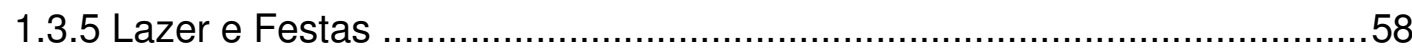

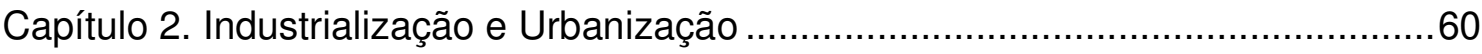

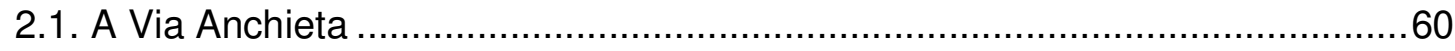

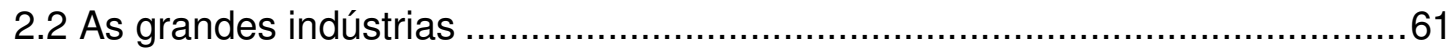

2.3. Especificidades do processo de industrialização e urbanização em Cubatão 66

2.4. Migração e Proletarização …………..........................................................

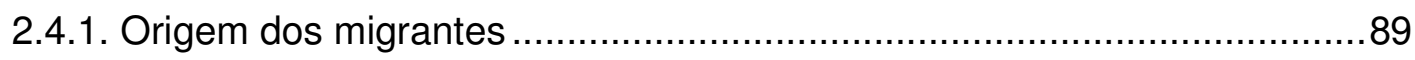

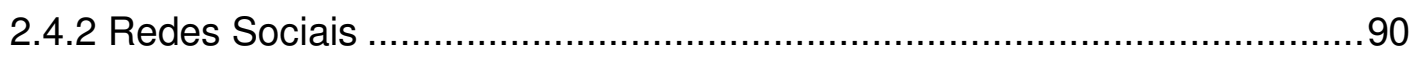

2.4.3. Desenraizamento, Exclusão e Resistência ...........................................96

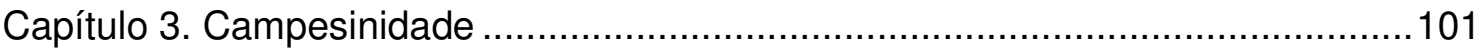

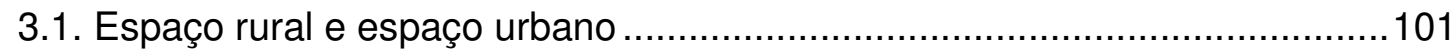

3.2 Discussão sobre Espaço Periurbano ………………………………........110

3.2.1 O espaço periurbano dos Pilões .......................................................116

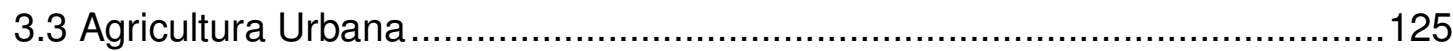

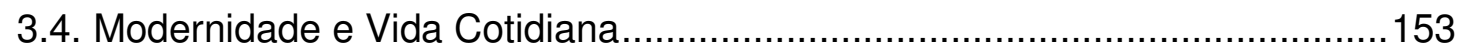

3.4.1 Atividades agrícolas, a criação de animais e a campesinidade ..............159

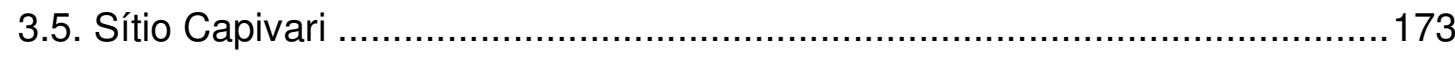

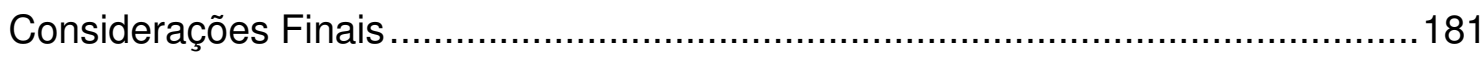

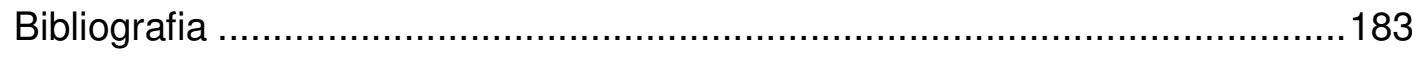

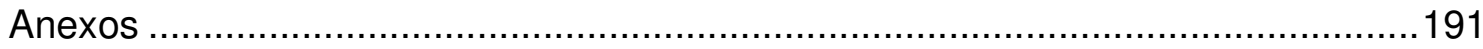




\section{Introdução}

Atualmente a cidade de Cubatão se destaca pela grande concentração de indústrias em seu território, e ainda guarda vestígios da época em que a banana era a principal atividade econômica do município. São pequenos sítios, a maioria localizados no Vale dos Pilões, onde os sitiantes não vivem mais do plantio da fruta, mas ainda mantêm algum tipo de atividade agrícola. A maioria das famílias donas de antigos sítios já não vive mais nesses locais, são novos moradores que agora ocupam essas terras. Isso porque, com o processo de industrialização, muitos sítios foram vendidos, desapropriados e até abandonados, para dar lugar às indústrias, a partir de 1950. O pacato povoado com um modo de vida tipicamente rural foi aos poucos sendo modificado através do processo de industrialização e urbanização. Desde a construção da primeira rodovia (Anchieta - em 1942), os trabalhadores migrantes atraídos para cidade passaram a ocupar diversos locais (próximos ao local de trabalho, área de mangue e encosta da Serra do Mar), uma vez que os custos de moradia eram altíssimos e os terrenos escassos, já que as indústrias utilizam uma vasta área ao longo da Serra do Mar em terrenos mais firmes. Vale lembrar, a escassez do espaço de modo geral e também é a forma como aparece a valorização da terra em Cubatão, com o desenvolvimento do centro industrial. (DAMIANI, 1984)

A paisagem rural do mar de bananeiras deu lugar a enormes construções, dando a impressão de que a cidade submergiu, ou até mesmo que ela foi construída no meio das fábricas. De tantas Vilas operárias, transformou-se numa cidade operária. Em 1970, conforme os estudos de Peralta (1979), 67,4\% da população de Cubatão eram

migrantes. A indústria necessitava de mão-de-obra abundante e barata, atraindo trabalhadores de várias partes do Brasil, utilizando, muitas vezes, uma rede não oficial de aliciamento desses trabalhadores. "A cidade se torna nordestina, quanto à população que passa a abrigar, ao mesmo tempo em que se internacionaliza, quanto à riqueza gerada em seu espaço". (DAMIANI, 1984, p. 12-13)

A cidade explodiu, as periferias surgiram em forma de favelas, ocupando áreas de mangues e áreas da Serra do Mar, fruto do processo de urbanização que priorizou os interesses do capital.

A cidade que se expande na explosão não é a cidade obra, apropriada pelos cidadãos, mas a cidade produto, a cidade do 
capital, aquela em que os valores de troca predominam sobre os valores de uso, uma cidade fragmentada, recortada, reconstruída sobre si mesma constantemente para maximizar a reprodução do capital. (LEFEBVRE, 1999 apud RAMOS 2002)

Há décadas atrás, a existência de hortas e a criação de animais já se destacavam na organização do espaço dessa cidade, fato que nos chamou a atenção, pois seu conteúdo demonstrava certa complexidade (remetendo à ética e valores camponeses).

O processo de urbanização é um processo de expropriação. E, em Cubatão, o urbano se apresenta com características de segregação espacial, fragmentado. Mas, considerando as contradições envolvidas no processo de reprodução do espaço, identificamos uma de apropriação do espaço com base na lógica do uso. A grande quantidade de migrantes acabou conferindo a esse espaço características ímpares, já que muitos são de origem camponesa. Os hábitos e costumes camponeses passaram a ficar mais evidentes e visíveis, através da apropriação do espaço com atividades agrícolas e algumas manifestações culturais, como as festas.

O presente estudo analisa a recriação de práticas e valores camponeses no contexto urbano de Cubatão, dada a ampla ocorrência dessas práticas nos dias atuais na referida área. Buscamos compreender o sentido dessas práticas a partir dos sujeitos sociais que as realiza: o trabalhador migrante. E para entender a inserção desse indivíduo como trabalhador assalariado na cidade, tivemos que considerar o tipo de urbanização característico desse local e o processo de proletarização ao qual ele se submeteu. Portanto, nossa análise considera as relações sociais e o espaço no qual elas se situam, considerando a vida cotidiana, a modernidade e as contradições inerentes à problemática do espaço.

Para a compreensão das práticas e valores camponeses, recorremos ao conceito de campesinidade de Woortmann (1990), uma vez que ele nos permite analisar a expressão de valores relativos à ordem moral como uma qualidade presente em maior ou menor grau em distintos grupos específicos. A flexibilidade do termo campesinidade, nesse aspecto, permitiu que estruturássemos nosso trabalho numa perspectiva mais ampla do universo camponês, uma vez que Woortmann não trata diretamente com trabalhadores urbanos. Seu conceito propiciou uma análise da 
subjetividade do camponês, ampliou as possibilidades de nossa análise, na medida em que a campesinidade não se restringe a um determinado espaço, podendo ser apreendida em contextos culturais particulares e variados, sendo uma qualidade comum a diferentes lugares e tempos.

As manifestações da campesinidade se apresentam em graus distintos de articulação ambígua com a modernidade, através da "apropriação individual em duas temporalidades internalizadas, onde os tempos modernos são usados para restabelecer o tempo tradicional..." (WOORTMANN, 1990, p. 19). Como consideramos as discussões sobre modernidade e vida cotidiana em nossa análise, o conceito de campesinidade pareceu-nos bastante adequado para fazermos nossa reflexão.

É importante salientar como a "cidade" é tratada no presente estudo, pois falamos de "cidade" e de "urbano", sendo assim, precisamos estabelecer como entendemos esses conceitos. Consideramos a definição proposta por Henri Lefebvre (2001) que caracteriza "cidade" como um espaço-tempo, uma realidade presente, imediata, um dado prático-sensível (material), arquitetônico, mas ao mesmo tempo em que tem presente uma estrutura social (que a torna sensível); é um pedaço do conjunto social e "incorpora na matéria sensível, as instituições, as ideologias". Os espaços desabitados e mesmo inabitáveis também a compõem. "Tanto isto é verdade que o 'habitat' não constitui a cidade", portanto "ela não pode ser definida por essa função". Ela também é uma "mediação entre as mediações", contém a ordem próxima e está contida na ordem distante, projetando esta última sobre o plano da vida imediata. Como mediação, a cidade é o único local onde se manifestam as contradições da sociedade, principalmente as que se referem a grupos diversos e ao poder político. Ela não pode ser concebida como um sistema significante, determinado e fechado enquanto sistema.

Quanto ao conceito de urbano, Lefebvre (1986) destaca que esse não designa simplesmente a cidade e a vida na cidade, nem coincide com a Pólis (Cité) e nem com a cidade (medieval), mas as substitui, englobando-as. O urbano pode ser entendido como espaço onde se desenvolvem a modernidade e a cotidianidade no mundo moderno, a forma atual da simultaneidade, da unidade, da reunião, da convergência e do encontro. Embora o urbano não dispense uma base prático- 
sensível, uma morfologia, ele não pode ser definido como apegado a essa; por outro lado ele não é algo que se pode se separar dela.

A pesquisa "A campesinidade presente na construção do espaço geográfico da cidade de Cubatão" partiu de nossa vivência por vinte e cinco anos na cidade de Cubatão alternada com longas visitas ao interior de Minas Gerais. Durante esse tempo algumas questões sempre vinham à tona, dado o intenso contato que tivemos com a realidade urbana e a rural. A diferença entre esses dois universos e suas semelhanças causava sempre estranhamento. Ficávamos observando como as pessoas se comportavam no espaço rural e no espaço urbano e também quando transitavam de um para outro. O interesse pelos fenômenos sociais levou-nos a fazer o curso de Ciências Sociais. Durante a graduação tivemos a oportunidade de cursar duas matérias no Departamento de Geografia: geografia urbana, ministrada pela professora Ana Fani A. Carlos e geografia agrária, ministrada pelo professor Ariovaldo Umbelino de Oliveira. A partir de então, começamos a nos interessar, especificamente, pelo modo de vida camponês. Por um determinado período nos envolvemos com o estudo do campesinato. Mas foi a partir do conteúdo trabalhado na disciplina "Campesinato: modo de vida e espacialização", ministrada pela professora Marta Inez Medeiros Marques, que conseguimos fundamentar o nosso argumento e elaborar um projeto de pesquisa que tratasse da relação campocidade. Desse projeto surgiu o presente trabalho.

\section{A pesquisa e o trabalho de campo}

Realizamos várias leituras e cursos referentes ao tema proposto, alternando com visitas a campo. Gostaríamos de destacar que nosso trabalho de campo se iniciou tomando como referência aquilo que mais chamou nossa atenção na paisagem de Cubatão: a quantidade de locais dispersos ocupados com hortas. Esses espaços estão em sua maioria localizados às margens das duas linhas férreas e de rodovias que cortam a cidade, o restante estão dispersos pela cidade em terrenos particulares, de empresas ou indústrias, em outras vias de circulação e também de forma mais expressiva em pequenos sítios. Além desses locais, encontramos hortas também em espaços bem inusitados, como por exemplo: locais de trabalho. 
Nossas primeiras visitas, de caráter exploratório, foram feitas ao Bairro Jardim 31 de março, onde na década de 1980 surgiram as hortas que ocupam as margens da linha férrea que corta o bairro. Esse local foi escolhido porque antecede ao projeto da prefeitura de criação de hortas comunitárias no município. Mesmo porque tive a oportunidade de acompanhar a manutenção dessas hortas após sua criação, pois residi no local entre 1972 e 1986. Nesse sentido, na tentativa de resgatar a história dessas hortas, contei com a ajuda de alguns antigos vizinhos que as mantiveram por muito tempo ou aqueles que ainda as mantêm. Como atualmente a cidade apresenta muitos espaços com hortas, alternei as visitas ao Jardim 31 de março com outros locais onde as hortas são cultivadas. (Mapa 4)

Procuramos compreender o significado dessas hortas para aqueles que as mantinham, além de buscar a interpretação de hábitos e valores relativos à cultura camponesa que a maioria dos migrantes expressava. Enfim, tentamos compreender a inserção dos elementos rurais no contexto urbano. Nesse caminho, muitas questões foram surgindo, pois à medida que íamos desvendando o sentido das hortas, outros elementos começaram a surgir, como a criação de animais na cidade. A princípio tínhamos observado um grande número de cavalos na cidade, mas até então não sabíamos o que estava por detrás desse fato. Foi então que descobrimos a Associação União dos Cavaleiros de Cubatão e, entrevistando alguns membros, pudemos nos inteirar da dinâmica que envolvia a criação de animais no município. Através dos novos entrevistados descobrimos novos espaços rurais e outros conflitos. Já estávamos fechando o campo quando foi preciso iniciar nova investigação dentro do pouco tempo que dispúnhamos para concluir a pesquisa.

Iniciamos então nosso trabalho de campo pelo Jardim 31 de março e estendemos a outros bairros, conforme o levantamento de dados que foi indicando novas direções a serem tomadas.

Tentamos elaborar uma descrição densa, com um viés qualitativo, com a finalidade de detectar a densidade dos dilemas que atravessam a vida dos sujeitos sociais que destacamos.

Em nossa pesquisa exploratória utilizamos um roteiro, passando mais tarde a entrevistas abertas, no intuito de apreender o subjetivo. De modo geral nossos entrevistados se mostravam solícitos em conceder a entrevista, permitindo também 
que fotografássemos as hortas e eles próprios. As anotações foram registradas em diário de campo (que posteriormente transformamos em relatório de campo). A maioria das entrevistas foi gravada em fita cassete e depois transcrita, para assim poderem ser analisadas. Respeitamos as construções das sentenças e as palavras, dada a riqueza que essas trazem para a interpretação da realidade vivenciada pelos locutores, representativas de uma cultura da fala e não da escrita (um mundo bem mais próximo de pessoas do que de coisas). As falas dos sujeitos revelaram um pouco de sua vivência, de como partilham a vida, e dominam outros códigos. (MARTINS, 2004)

Não só as falas foram consideradas em nossa análise, mas também o silêncio, o não dito - que às vezes dizem mais do que um conjunto de idéias.

Procuramos preservar a identidade das pessoas não as identificando pelo nome.

Em Cubatão visitamos várias instituições, arquivo histórico, prefeitura, associações e jornais. Em São Paulo procuramos o Instituto Florestal (que administra o Parque Estadual da Serra do Mar), bibliotecas e prefeitura. Realizamos pesquisa na internet, participamos de discussões sobre questões urbanas e rurais, seminários, e longas conversa com a orientadora Marta Inez Medeiros Marques - fundamentais para o desenvolvimento do trabalho. A realização do trabalho de campo embora parecesse uma tarefa fácil, não foi. O início foi bastante difícil e com o desenrolar do trabalho novos elementos o tornaram ainda mais complexo. A professora Marta dispensou grande atenção em nos orientar nessa fase.

A orientação de nossa pesquisa tem como base a dialética materialista marxista pensada a partir de alguns autores como Carlos (1986, 1994), Damiani (1984, 1997, 1999 a.,1999 b, 2002 e 2005), Gaudemar (1977), Henri Lefebvre (1980, 1986, 1999, 2001), Maia (1994), Marques (2000, 2002, 2003, 2004), Martins (1986, 1993, 1995 , 1997, 1998, 2000, 2002), Oliveira (1986, 1996), Póvoa-Neto (1995), Seabra (1986, 2003, 2004) e Woortmann (1990).

Nossa preocupação foi realizar um trabalho construído com base no método regressivo-progressivo, proposto por Henri Lefebvre, ancorado na dialética materialista marxista. Lefebvre reconhece na realidade social uma dupla complexidade: horizontal e vertical. A primeira está inscrita no visível, por isso 
precisamos descrever, a partir de um conhecimento teórico, o que observamos. As observações, as entrevistas, enfim, todos os dados que pudemos captar sobre a realidade que estudamos foram registrados. Passamos então para a análise da complexidade vertical, identificando a coexistência de relações sociais referentes a diferentes temporalidades e procurando "datá-las". Nesse procedimento, descobrimos a existência de diferentes temporalidades coexistindo de forma simultânea no tempo moderno capitalista. Uma vez identificadas as relações sociais, decifrando suas origens, é preciso voltar à superfície, passando ao encontro do presente a fim de descobrir as contradições. O movimento da pesquisa passou então pela primeira fase (descritiva), pela segunda fase (analítico-regressiva) e pela terceira fase, ou momento, denominado de histórico-genético.

Embora, no início, tivéssemos o privilégio de uma situação participante, também nos aproveitamos do afastamento num segundo momento (quando foi possível investir na objetividade), na busca de base teórica fornecida pela sociologia e pela geografia. Berger (1972 apud MARTINS, 1993b) denomina esse deslocamento de "alteração biográfica", pois é o momento que os momentos por nós vivenciados em nossa história pessoal tornam-se "distantes e externos para nós, numa relação de certo modo objetiva, como a do etnógrafo em relação ao grupo que estuda".

\section{A organização do nosso trabalho segue da seguinte forma:}

No capítulo 1, "Da condição de Porto a Cidade Industrial", apresento um pouco da história de Cubatão, caminho de ligação entre o Planalto e a Baixada Santista, suas funções de porto e posto fiscal como principal atividade econômica. Ao longo do capítulo apresento seu desenvolvimento a partir da produção da banana e posteriormente destaco as indústrias pioneiras.

No capítulo dois, "Industrialização e urbanização", descrevo a segunda fase de industrialização a partir de 1950, que causou profundas transformações em Cubatão. Discuto também o tipo de urbanização que resultou da referida industrialização, bem como a migração e a proletarização. Apresento também algumas contradições do espaço. 
No capítulo três, "A campesinidade espacializada", discuto as condições e a forma de espacialização do migrante em Cubatão, destacando as contradições constitutivas da reprodução do espaço. Nesse capítulo analiso o sentido das atividades agrícolas e da criação de animais exercidas pelos moradores de Cubatão, considerando a campesinidade dos sujeitos envolvidos.

Cubatão (Mapa 1) é uma cidade que possui 108.309 habitantes (IBGE, 2000) e se localiza no litoral do Estado de São Paulo, na raiz da Serra do Mar; dista cerca de 57 $\mathrm{km}$ da Capital do Estado de São Paulo e $16 \mathrm{~km}$ da cidade de Santos e possui uma área é de $148 \mathrm{~km}^{2}$. A sua topografia (PERALTA, 1979) apresenta duas áreas distintas: uma na Serra do Mar com altitudes que atingem $700 \mathrm{~m}$ e outra na planície, composta por depósitos marítimos, mangues fluviais, brejos, antigos depósitos de areia de origem marítima e morros isolados (com altitudes mínimas de 3 metros). Possui um clima diferente do resto da Baixada Santista devido à escarpa da Serra que forma uma barreira climatérica, apresentando condensação de umidade em forma de nuvens, neblina e cerração. A elevada umidade favoreceu o desenvolvimento de rica cobertura florestal e, devido à altitude, a temperatura aí é mais baixa dois a três graus em relação à planície, porém é mais elevada que na orla litorânea, devido à escassez de brisas (própria da região de manguezais). Os manguezais impediram a ligação, por terra, entre a Serra do Mar e a cidade de Santos até o terceiro século após o descobrimento do Brasil.

Limites municipais: São Bernardo do Campo, Santo André, São Vicente e Santos.

A região é servida por várias vias fluviais: Rio Cubatão, Rio Pilões, Rio Mogi, Rio Perdido, Rio Perequê e Rio das Pedras. Os canais de maré ou braços de mar são: Santana, Paranhos e Casqueiro.

Cubatão possui 40 bairros urbanizados (segundo classificação da prefeitura) e 20 considerados como área de invasão. No entanto, quase metade da população está concentrada em 5 deles: Jardim Casqueiro, Vila dos Pescadores, Vila Natal, Vila Nova e Vila Esperança. (PINTO, 2005) Sendo que a Vila dos Pescadores e a Vila Esperança são considerados como área de invasão. 


\section{MAPA 1 - Localização do Município de Cubatão}

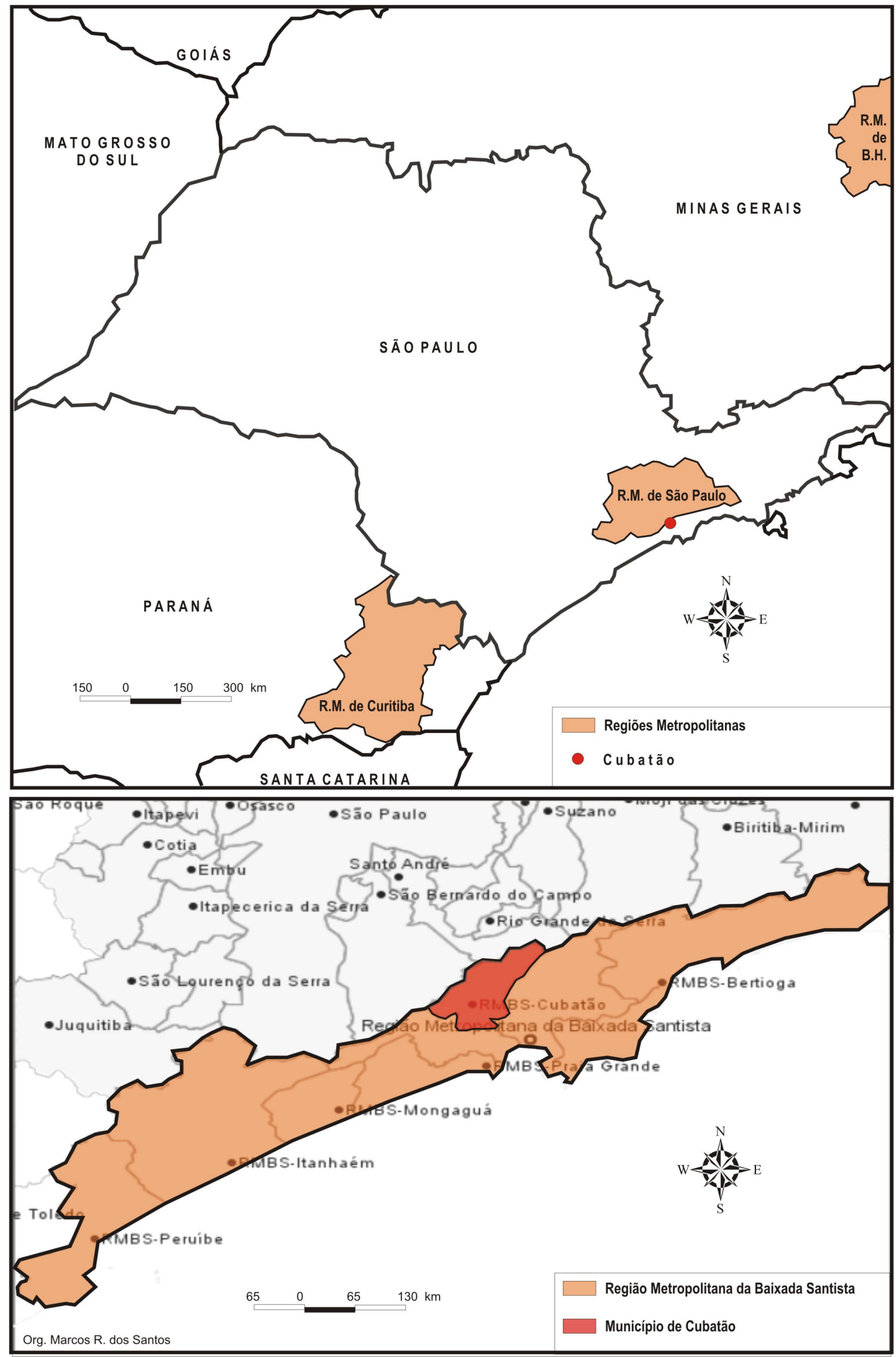




\section{Capítulo 1. Da condição de Porto à Cidade Industrial}

\subsection{0 caminho de ligação com o Planalto}

Sabemos que o único interesse do rei de Portugal pelas terras brasileiras, logo após o descobrimento, era a extração do pau-brasil, sendo então implantadas benfeitorias $^{1}$ no país. A existência do produto em território brasileiro aguçou 0 interesse de alguns países do continente europeu, como a França - que iniciou buscas em nosso território desde 1504. O fato preocupou o governo português, levando-o a pensar em medidas que garantissem a posse da terra, dada a descoberta de ouro na América espanhola e a diminuição da intensidade do comércio com o Oriente.

Esse foi um aspecto de fundamental importância no que se refere ao processo de colonização no Brasil, iniciado por Martim Afonso de Souza, encarregado de distribuir sesmarias ${ }^{2}$ e combater os franceses. Das capitanias hereditárias instaladas em 1534, as que obtiveram êxito foram as de Pernambuco, e São Vicente, localizadas hoje, respectivamente, no estado de Pernambuco e no litoral paulista.

Até 22 de março de 1681, as terras de Cubatão pertenciam à Capitania de São Vicente, mas com sua extinção, Cubatão passou a pertencer à Capitania de São Paulo. A primeira referência às terras de Cubatão ${ }^{3}$ foi feita em 1553, através de um documento concedendo as três primeiras sesmarias a Pero Góes, a Rui Pinto e a seu irmão Francisco Pinto. A sesmaria pertencente a Pero Góes ficava na margem esquerda do Rio Mogi, onde atualmente encontra-se a Companhia Siderúrgica

\footnotetext{
${ }^{1}$ As benfeitorias eram lugares fortificados que também eram utilizados para o armazenamento do pau-brasil.

${ }^{2}$ Segundo José de Souza Martins (1995), a doação de terras denominada "sesmarias" dava ao rei uma propriedade eminente sobre as terras concedidas sob esse regime e não passava de uma relação de arrendamento, pois o rei podia recuperar plenamente a posse das terras que fossem abandonadas ou que não produzissem os tributos requisitados. Posteriormente, as sesmarias se tornaram propriedade privada através da Lei de Terras de 1850. Com isso, o autor citado ressalta que as sesmarias não eram um direito, mas uma retribuição, pois servia aos interesses do rei. Assim, pode-se dizer que a relação era entre vassalo e senhor: caracterizava-se como uma relação de "troca de favor". E como aqui existiam poucos sesmeiros, mesmo descumprindo as regras impostas pela Coroa, dificilmente aplicava-se a pena estabelecida pelo rei. De qualquer forma, entendemos as sesmarias como concessão de uso: não é propriedade e também não é domínio. No entanto, independente de seu uso ser produtivo ou não, no Brasil, as sesmarias ficaram como direito de propriedade - como nos ensina Ariovaldo Umbelino de Oliveira.

${ }^{3}$ Hoje, grande parte do município cubatense corresponde às três primeiras sesmarias doadas.
} 
Nacional (Cosipa). A segunda sesmaria, concedida a Rui Pinto, ficava à margem direita do Rio Mogi e à esquerda do Rio Perequê, onde hoje estão localizadas as empresas Union Carbide, Alba, Rhodia, Carbocloro e Petrobrás. A Francisco Pinto, coube a sesmaria situada entre a margem esquerda do Rio Perequê e a direita do Rio Pilões, área ocupada atualmente pela Usina Henry Borden, a Refinaria, a Santista de Papel e a Ultrafértil (PINTO, 2005). Somaram-se a elas outras sesmarias doadas a mais seis pessoas: Antônio Rodrigues de Almeida, Gonçalves de Araújo, Diogo de Unhate, Simão Manoel de Queiroz, José Correa Leme e Pedro Guerra (IBGE, 1952 apud PINTO, 2005).

O Porto Geral do Cubatão foi elevado à categoria de município em $1833^{4}$, com o nome de Cubatão, porém, devido a sua decadência portuária, em 1841 uma Lei Provincial ${ }^{5}$ determinou que a povoação de Cubatão fosse incorporada à cidade de Santos. Somente no ano de 1922, ela conseguiu o título de Distrito de Paz, porém definido como distrito do município de Santos, com delimitação geográfica precisa, entre 1933 e 1948. Só em 1949 a cidade conseguiu sua autonomia efetiva.

A ligação entre a Capitania de São Vicente e o planalto era feita através da utilização de trilhas, passando pelas terras e rios que hoje pertencem à cidade de Cubatão. Situada no sopé da Serra do Mar, a importância da localidade foi crescendo, dada sua localização e função portuária. O transbordo de pessoas e cargas era feito em terras cubatenses.

A transposição da Serra do Mar não era tarefa fácil. Tanto os índios quanto os desbravadores portugueses sabiam disso. A antiga trilha indígena dos tupiniquins, também conhecida como Caminho de Piratininga e Sendeiro do Ramalho, se mostrava a melhor opção para a ligação com o Planalto, uma vez que apresentava pontos que favoreciam a subida. Esse caminho era feito na região onde hoje fica o município de Cubatão. Com o passar dos anos, o caminho sofreu transformações que possibilitaram não só o aquecimento das exportações brasileiras através do Porto de Santos, mas também influenciou diretamente a constituição da cidade de Cubatão, que assumiu diferentes funções: porto, caminho e posto fiscal.

\footnotetext{
4 A Lei Provincial n‥ 24 do dia 12 de agosto de 1833, sancionada pela Regência em nome do Imperador D. Pedro II, designou o Porto Geral de Cubatão como povoação.

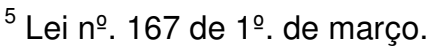


Couto (2003), em estudo recente, relata que, antes do descobrimento, a ligação entre o planalto e a Baixada era feita através do Rio Mogi. Porém, autores como Pinto (2005), Ferreira \& Passerani (2005) e Damiani (1984) afirmam que a trilha dos tupiniquins foi o elo primitivo de ligação traçado pelos índios. No entanto, ressaltamos que tanto a trilha quanto o rio estão localizados no vale do Rio Mogi. Seja a pé ou de barco, a localidade é a mesma. A trilha, de fato, foi muito utilizada pelos portugueses no século XVI.

Em 1560, segundo recomendações do Governador-Geral do Brasil, Mem de Sá, a trilha dos tupiniquins deixou de ser utilizada devido a ataques constantes dos índios Tamoios, que na época eram aliados dos franceses. Como alternativa, no Vale do Rio Perequê, em Cubatão, foi criado um novo caminho para o Planalto, conhecido como Caminho do Padre José ou Caminho do Monge $^{6}$, utilizado pelo próprio Anchieta.

As terras de Cubatão serviam como ponto de apoio, tanto para os que subiam quanto para os que desciam a Serra. Assim, há o registro de três Portos na cidade. O primeiro, denominado de Piaçagüera, que significa porto velho em tupi, ficava às margens do Rio Mogi, logo no início da "Trilha do Piratininga". O segundo Porto recebeu o nome de Porto das Almadias ou Armadias, e "ficava na foz do Rio Perequê", afluente do Rio Cubatão - o maior e mais importante rio, com $177 \mathrm{~km}$ (PINTO, 2005). Mais tarde, Martim Afonso passou a chamá-lo de Porto de Santa Cruz, que funcionou por mais de cem anos. Finalmente, temos o último Porto, o Porto Geral de Cubatão, que funcionou por um período de mais de dois séculos. Ele iniciou suas atividades entre 1600 e 1650. E durante essa época, a margem do Rio das Pedras passou a ser utilizada. Independentemente dos Portos, ainda se utilizava o Caminho do Padre José. Ao longo dos anos, os Portos instalados em Cubatão deram origem a pequenos povoados, mas foi a instalação do Porto das Armadias que, de fato, iniciou o povoado que se transformaria na atual cidade de Cubatão.

Os jesuítas adquiriram várias terras na região e construíram igrejas, seminários e colégios na Baixada, porém a maior porção de suas propriedades estava concentrada em Cubatão. A primeira delas foi obtida através de uma doação de

\footnotetext{
${ }^{6}$ Esse caminho ficou conhecido pelas dificuldades que apresentava na escalada.
} 
Lobo Ribeiro Pacheco e Maria de Almeida Paes no ano de 1643, seguida da doação de Francisco Pinto em 1664 e posteriormente a de Domingos Leite de Carvalho, que fez sua doação em 1679. Além das terras recebidas, em 1743, os jesuítas arrendaram as propriedades pertencentes a Rui Pinto e a Agostinho Rodrigues da Guerra, e logo depois as terras de Manuel Antunes Belém Andrade. Sob o domínio dos jesuítas, as terras que margeavam o Rio Cubatão formavam uma vasta área, conforme nos demonstra Tulik (1987, p. 119):

Os jesuítas, cuja atuação foi muito ampla, possuíam além dos colégios de São Vicente e Santos, algumas fazendas... Até fins do século XVII, foram proprietários de fazendas no Cabuçu, junto ao rio São Miguel; no Jaguaréguava que deu origem à Fazenda dos Pelaes; e no Cubatão. Esta última constituía a propriedade mais importante dos jesuítas sendo a que apresenta maior significado para a geografia da região. (...) A fazenda Geral do Cubatão, iniciada em 1643 com a doação da sesmaria do rio Pilões, foi aumentando, progressivamente, até 1743 através de compras, permutas e doações chegando a ocupar vasta área da Serra do Mar e vales dos rios Cubatão, dos Pilões, das Pedras, Perequê e Mogi.

O poderio se concretizou com a construção de um sobrado ${ }^{7}$, considerada a maior obra do povoado, à margem direita do rio. A construção funcionava como sede da Fazenda Geral e ponto de catequese, além de abrigar viajantes religiosos que passavam por ali. De posse das terras de ambas as margens do rio, e alegando muitos gastos com a catequização, os jesuítas resolveram instalar uma alfândega para a cobrança de pedágio de pessoas, animais, embarcações e mercadorias, na travessia de uma margem para a outra. Eles não só cobravam pela passagem e utilização da parte do rio que banhava suas terras, como também passaram a ter o direito de fazer o transporte de cargas e pessoas até Santos. O fato gerou discussões entre o Provedor da Fazenda de Santos, os religiosos e a Coroa, no entanto, o monopólio permaneceu.

\footnotetext{
${ }^{7}$ Atualmente nesse local fica o Largo do Sapo, com um monumento em homenagem aos homens que transportaram muitas mercadorias no Rio Cubatão.
} 
De acordo com Peralta (1971), a alfândega de Cubatão ${ }^{8}$ é anterior à alfândega de Santos, tendo iniciado suas funções no final do século XVII e começo do século XVIII. A partir da instalação da alfândega em Cubatão, cobravam-se duas taxas sobre as mercadorias: uma em Cubatão e outra em Santos. Como o principal produto de exportação era o açúcar - em grande quantidade - Cubatão auferiu lucro considerável através da função fiscal.

Segundo Pinto (2005), os índios transportaram as mercadorias por 200 anos. Somente em 1750 é que os tropeiros, utilizando mulas, passaram a transportar as mercadorias, fato antes relatado por Goldenstein (1970). A mudança na economia paulista, segundo Pinto, foi o que ocasionou a alteração na forma de transporte das mercadorias.

Em 1759, quando os jesuítas foram expulsos de Portugal, bem como de todas as suas colônias, a cobrança do pedágio passou a ser feita pela Coroa portuguesa, a nova dona das terras, até seu arrendamento a terceiros. Em 1818 essas terras passaram para as mãos de colonos açorianos, através de doação.

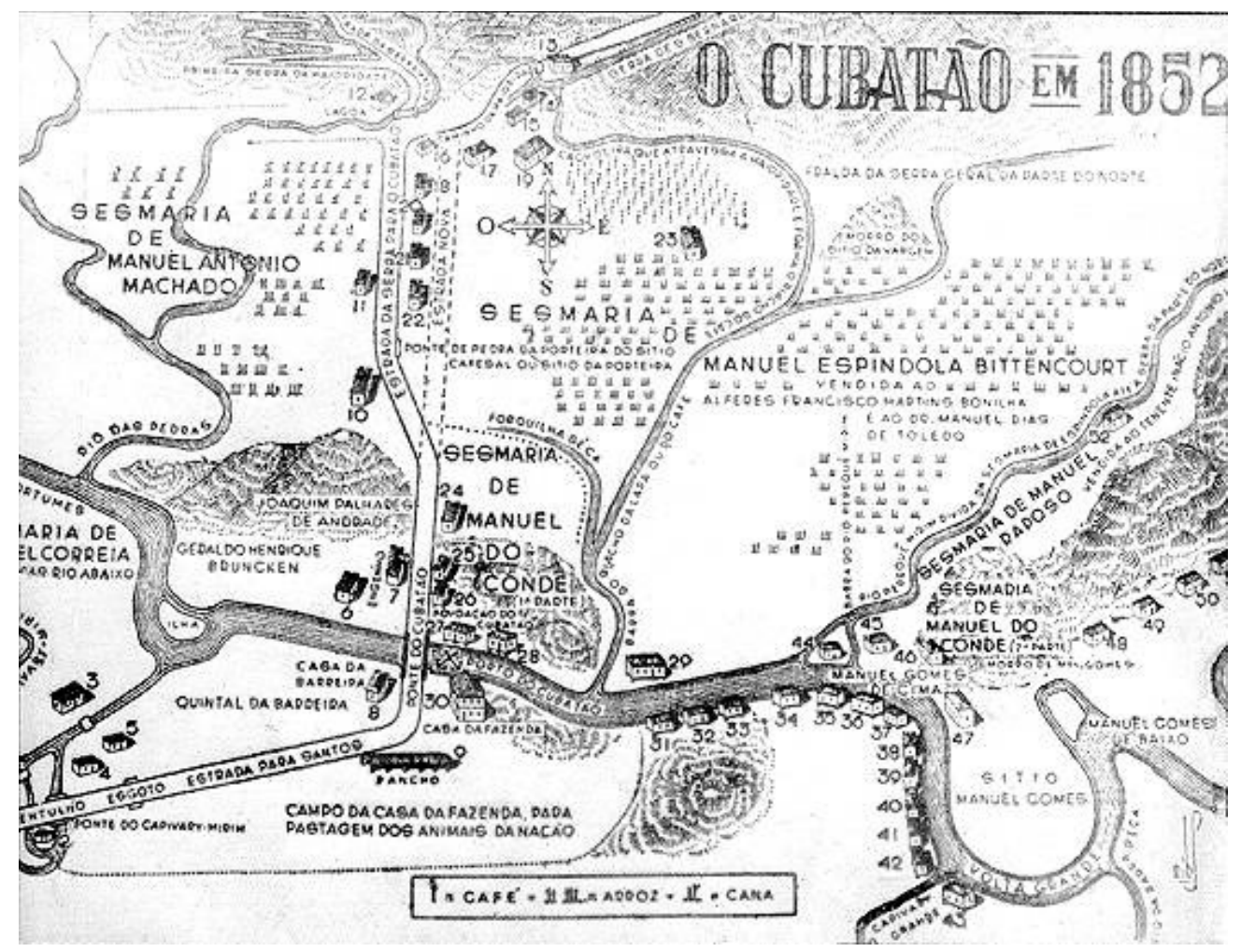

Figura 1: Terra dos cinco Manuéis (sesmarias). (1892).

Fonte: COSTA E SILVA SOBRINHO 1957 apud PERALTA 1979, p. 20.

\footnotetext{
${ }^{8}$ Instalada junto ao Porto Geral de Cubatão, ela possuía uma Casa da Guarda.
} 
A partir da conclusão da estrada "Calçada do Lorena", em $1792^{9}$, ainda uma estrada de tropas, o comércio de exportação foi intensificado. Nela, podiam se fazer viagens noturnas, antes impensáveis. O interesse no empreendimento partiu do então governador da Capitania de São Paulo: Bernardo José Maria de Lorena. A criação da estrada "Calçada do Lorena", juntamente com o aumento da produção de açúcar levou os tropeiros a passarem por ali com mais freqüência. $O$ tráfego das mulas era tão intenso, que causava agitação no pequeno núcleo de Cubatão. Os tropeiros faziam seu pouso por lá e construíram ranchos para descanso e para se protegerem das chuvas da região, dando também descanso e alimentação aos animais ${ }^{10}$. Ali ficava o ponto final das tropas, onde as cargas e os passageiros eram baldeados para Santos. De São Paulo, eles partiam com açúcar bruto ${ }^{11}$, aguardente de cana e toucinho, e na volta levavam vinhos portugueses, sal, vidros, ferragens e fardos de mercadorias (FLORENCE ${ }^{12}, 1825$ apud PERALTA, 1979).

A descida da Serra era feita pela "Calçada do Lorena", porém o transporte de mercadorias até o Porto de Santos enfrentava alguns percalços: ora a chuva molhava o açúcar, ora o percurso em partes mais profundas do Rio Cubatão virava as pequenas embarcações, isso quando não entrava água nos barcos, danificando as mercadorias. Como o problema era recorrente, eles buscaram uma alternativa para o transporte até Santos, pois a produção do açúcar estava aumentando nos municípios de Jundiaí, Mogi-Guaçu, Piracicaba e Sorocaba, e a insuficiência de barcos disponíveis era uma realidade. Pressionado pelos fazendeiros produtores de açúcar e seus representantes, os comerciantes de Santos, o então Governador da Capitania de São Paulo, José de Franca e Horta, dedicou-se em seu governo, entre 1802 e 1811, a realizar melhorias nos caminhos. O comércio exterior dependia

\footnotetext{
${ }^{9}$ A primeira estrada pavimentada do Brasil, feita de lajes de pedra, com uma largura que variava entre 3,20 e 4,20 metros. Sua extensão era de aproximadamente $8 \mathrm{~km}$. Uma façanha muito admirada, tendo como destaque seu traçado que permitia o desvio dos rios e cachoeiras da Serra (que por sinal eram muitos). A passagem das mulas foi facilitada pelo desenho em zigue-zague, permitindo o encontro de duas tropas confortavelmente (PINTO, 2005, p. 31).

${ }^{10} \mathrm{O}$ conde de Sarzedas, Bernardo José Maria de Lorena, ordenou que se formasse um pasto junto ao Largo do Sapo para servir de alimentação das mulas. (FERREIRA \& PASSERANI, 2005, p. 31)

11 "O açúcar era o principal produto que transitava por Cubatão. Em 1825/26 passava pelo local cerca de 500 a 550.000 arrobas anuais de açúcar". (PERALTA, 1979, p. 21).

${ }^{12}$ Florence era viajante e fez esses relatos no ano de 1825. Ele, juntamente com os viajantes Willian John Burchell e August Saint-Hilaire, registrou das atividades dos tropeiros.
} 
dessa via de comunicação, segundo Peralta (1979), e os antigos caminhos estavam sempre em péssimas condições devido às precipitações pluviométricas na região.

\subsection{O início do povoamento e o desenvolvimento da agricultura}

Diante da conjuntura econômica da época e reconhecendo a necessidade de promover melhorias no ponto estratégico de Cubatão, o governador de São Paulo, José de Franca e Horta, passou a dispensar maior atenção ao pequeno núcleo de povoamento. Ele ordenou a edificação da povoação na extinta fazenda dos jesuítas, entre os rios Capivari e Santana, na margem direita do Rio Cubatão, em 19 de fevereiro de 1803. O deslocamento da povoação, do Porto Geral de Cubatão, na margem esquerda do rio Cubatão, antigo largo do Sapo, para a margem esquerda do rio, no lugar da extinta Fazenda dos Jesuítas, foi feito devido a situação privilegiada do local.

Em 22 de agosto do mesmo ano, um edital convidava famílias de lguape para residirem no local (COSTA E SILVA SOBRINHO, 1957 apud PERALTA 1979). Outras medidas foram tomadas com o mesmo intuito, porém sem muito êxito. $O$ início da colonização oficial se deu com a chegada de cinco famílias numerosas e seu estabelecimento nas terras dos jesuítas. Eram as famílias dos "Cinco Manuéis", que somente em 7 de janeiro de 1819 tornaram-se proprietários das terras ${ }^{13}$ onde foram habitar. Eles iniciaram o plantio do trigo e do linho, mas, como não tiveram sucesso, começaram a plantar mandioca, café, arroz e cana. Mas como não receberam ajuda para colheita nas duas primeiras culturas plantadas, enfrentaram fome e miséria. Porém, com o sucesso na segunda etapa do plantio conseguiram a estabilidade. A agricultura era até então, de subsistência.

\footnotetext{
${ }^{13}$ Essas terras se referiam às Sesmarias e, segundo Peralta (1979), possuíam tamanhos variados: 400, 46, 190 e 400 braças.
} 


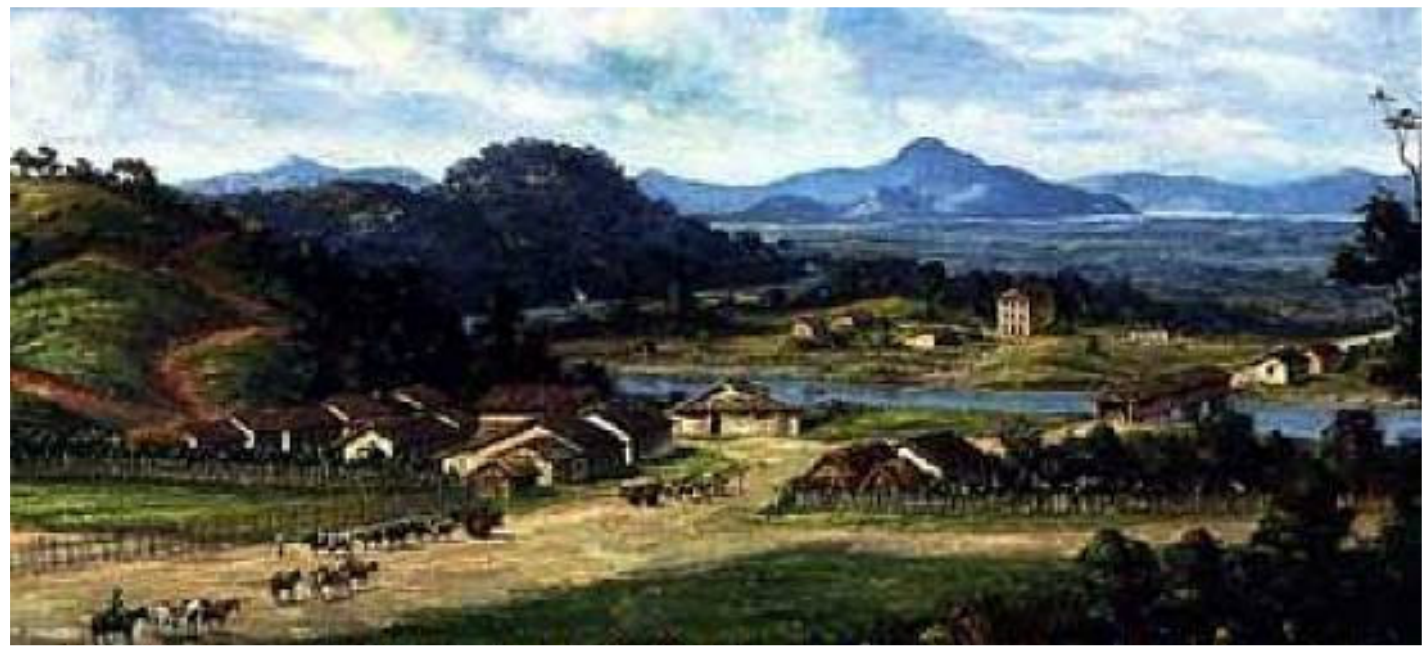

Figura 2: Tela de Benedito Calixto (1922) - Vista de Cubatão (1826) - óleo sobre tela. Em primeiro plano identificamos o pouso dos tropeiros, com local para o pasto dos animais, e um pequeno povoado. A casa maior, às margens do rio, se localizava onde hoje se encontra a Praça Coronel Montenegro, antigo Largo do Sapo. Ao fundo avistamos o Rio Cubatão com sua ponte de madeira coberta, hoje a ponte principal da cidade denominada de Ponte do Arco. Do outro lado do rio destaca-se o sobrado dos Jesuítas.

Fonte: <http://www.novomilenio.inf.br/cubatao/> Acesso: 26 abr. 2006

A Calçada do Lorena cumpriu bem sua função até o ano de 1820, mas depois se tornou insuficiente para suportar o grande tráfego de mercadorias e pessoas. Naquela ocasião era necessária uma estrada que comportasse carroças, pois a Calçada do Lorena apresentava degraus, e em alguns trechos parecia uma escada. Era necessária a construção de uma estrada que favorecesse o uso de carros de boi (PINTO, 2005). Diante disso, foi construída a Estrada da Maioridade, em referência à maioridade de D.Pedro II no ano de 1840, entregue em 1846 (DAMIANI 1984; GOLDENSTEIN, 1970). A nova estrada contava apenas com 12 voltas ao longo da Serra do Mar, ao passo que a Calçada do Lorena apresentava 133 voltas. Posteriormente, José Vergueiro fez algumas modificações na Estrada da Maioridade, diminuindo bastante o tempo de viagem entre Santos e São Paulo - tais modificações levaram a estrada a ser conhecida como Estrada do Vergueiro.

Houve, então, uma melhora considerável no trajeto entre a cidade de São Paulo e o litoral, no entanto, as mercadorias encontravam entraves no trecho entre Cubatão e Santos. O Porto de Cubatão também não dava conta de escoar a produção vinda de São Paulo, e as freqüentes perdas de mercadorias durante o transporte fluvial foram os principais motivos que levaram as autoridades a pensar em uma alternativa para alcançar o Porto de Santos. Peralta (1979) recorda uma crise catastrófica ocorrida 
em Cubatão devido à escassez de transporte no ano de 1826. Nessa época, o café ${ }^{14}$ também passou a ter grande importância, foi então que surgiu a idéia de se construir uma ligação por terra entre a cidade de Santos e Cubatão. Em 22 de fevereiro de 1825 tiveram início as obras do Aterrado, concluído em 1827. Com as obras concluídas, $13 \mathrm{~km}$ de extensão, incluindo quatro pontes, a ligação entre Santos e Cubatão já não dependia de canoas.

Três meses após a conclusão do Aterrado o tráfego foi suspenso devido à queda de uma das pontes. O Aterrado também era conhecido como "Via Bandeirantes". O trajeto começava no pontilhão da Estrada Velha - próxima à raiz da Serra, onde hoje se localiza a Refinaria Presidente Bernardes, e se estendia até a Alemoa, no município de Santos. A partir de 1970, no trecho que corta a cidade, a Via Bandeirantes recebeu o nome de Avenida 9 de abril até a ponte do Rio Casqueiro. De acordo com Pinto (2005), a construção do Aterrado enfrentou inúmeras dificuldades, como falta de materiais e mão-de-obra. Esta última solucionada com a contratação de imigrantes, em sua maioria alemães, mas que devido às más condições de vida, grande umidade, doenças, calor excessivo e muitos mosquitos, acabavam abandonando 0 trabalho. $A$ isso se acrescenta 0 fato da falta de residências para acomodar todos os trabalhadores. A migração portuguesa foi seguida pela alemã.

Em 12 de agosto de 1833, D. Pedro II sancionou a Lei Provincial $n \div$. 24, designando o Porto Geral de Cubatão como povoação, porém, ela foi incorporada à cidade de Santos em 1841. Após a construção do Aterrado, em 1835, Cubatão passou da condição de porto fluvial e posto fiscal, para a condição de Barreira. A principal casa da vila denominava-se "Casa de Registro", onde se cobrava uma pequena taxa de passagem, o registro do nome e a nacionalidade de cada passageiro que por lá passasse (KIDDER, 1940 apud PERALTA, 1979).

A alfândega, ou Registro de Cubatão, que proporcionara um relativo desenvolvimento ao povoado, foi extinta na primeira metade do século XIX, quando deixou de ser útil, devido à construção do Aterrado. Em seu lugar foi criado, na margem do rio Cubatão, um

${ }^{14} \mathrm{O}$ café ultrapassou a quantidade de açúcar exportado já em 1850. Foram 470.054 arrobas de café contra 344.904 arrobas de açúcar no mesmo ano. (GOLDENSTEIN, 1970). 
outro posto de arrecadação, denominado "Barreira do Cubatão" (PERALTA, 1971, p. 88).

As barreiras eram uma espécie de pedágio, cobrado sobre mercadorias, animais e pessoas, e foram criadas oficialmente pela Divisão do Tesouro Provincial de São Paulo, a partir da Lei no. 11 de 24 de março de 1835, com o intuito de se investir na conservação e desenvolvimento das estradas das províncias.

Goldenstein (1970) relata que a cobrança de tributo de passagem se iniciou com os jesuítas em 1713, continuando com a Coroa Portuguesa e se estendendo até depois da construção do Aterrado que ligava Cubatão a Santos, em 1827 (PETRONE, 1965 apud GOLDENSTEIN, 1970).

O Aterrado foi uma obra de fundamental importância para o desenvolvimento local, mas não podemos nos esquecer das circunstâncias nas quais os investimentos em Cubatão foram feitos desde os primórdios: sempre em função do Porto de Santos e da capital São Paulo. Tanto o trabalho de Goldenstein (1970) como o de Peralta (1979) e o de Damiani (1984) esclarecem bem. Vejamos:

O sistema de transportes da Baixada Santista que a liga ao resto do Estado de São Paulo, passando por Cubatão, traz exemplos de outros momentos dos investimentos considerados: a São Paulo Railway, inaugurada em 1867, fruto de investimentos ingleses, transformada, após ser encampada pelo Governo Federal, em Estradas de Ferro Santos-Jundiaí em 1946, e, em 1957, passando a fazer parte da Rede Ferroviária Federal S/A, empresa estatal, que, junto com as estradas de rodagem, a Estrada da Maioridade (1846), mais tarde, Estrada do Vergueiro e Estrada do Mar, com traçados modificados, e depois denominada Estrada Velha, que reuniu desde investimentos do Estado de então, até de particulares, compuseram, fundamentalmente, parte das condições gerais necessárias à comercialização do café; o sistema rodoviário, movido pelo desenvolvimento industrial de São Paulo, ampliou-se, em seguida, com a via Anchieta, construída de 1939 a 47, a partir de capitais estatais (DAMIANI, 1984, p. 19).

Com relação especificamente ao Aterrado, Peralta (1979, p. 30) salienta: "O empreendimento, contudo não foi realizado em função do povoado, mas sim dos 
interesses econômico-políticos das autoridades e produtores de açúcar da Província de São Paulo". ${ }^{15}$

\subsubsection{A ferrovia}

Conforme relatamos, a "Estrada da Maioridade", conhecida e mantida até os dias atuais como "Caminho do mar" ${ }^{16}$, embora significasse um avanço no transporte das mercadorias entre o Planalto e o Porto de Santos, uma vez que era uma estrada carroçável, ainda não era adequada, frente ao grande volume de mercadorias que necessitava ser transportado. O número de passageiros também aumentara consideravelmente. Por isso, já se pensava num projeto que ligasse São Paulo e Santos através de uma linha férrea. Segundo Peralta (1971, p. 50):

A necessidade da sua execução era reconhecida por todos. Já em 1855 o conselheiro Saraiva, presidente da Província, calculava em 3 milhões e quinhentos mil arrobas o volume de gêneros que deveriam ser transportadas pela via férrea. $\mathrm{O}$ transporte de passageiros era também volumoso, pois passavam pela Barreira do Cubatão anualmente cerca de quarenta mil cavaleiros.

A partir do decreto 1.759 (PERALTA, 1979) do ano de 1856, D.Pedro concedeu, a um grupo organizado pelo Barão de Mauá, o privilégio da construção, uso e gozo por 90 anos, da primeira via férrea do Brasil. A proposta da nova linha férrea foi apresentada aos ingleses pelo Barão de Mauá, que juntamente com eles fundou "The São Paulo Railway Company Limited", com sede em Londres.

O progresso econômico do Brasil, nesse período, dado pela produção do café, viabilizou investimentos estrangeiros no país. Os serviços públicos brasileiros, que exigiam grandes somas de dinheiro para serem criados e mantidos acabavam

\footnotetext{
${ }^{15}$ Segundo a autora, com a elevação do Brasil a Reino Unido em 1815, a Capitania de São Paulo passou a denominar-se Província de São Paulo.

16 "Em 1913, o empresário Rudge Ramos resolveu fundar a empresa Sociedade Caminho do Mar com o objetivo de construir uma estrada moderna entre São Paulo e o alto da Serra, financiada com a cobrança de pedágio. Do alto da Serra até Santos, a obra seria realizada pelo Estado. Essa estrada foi denominada Caminho do Mar (Estrada Velha) e, praticamente, reconstruiu a Estrada da Maioridade. A partir de 1920 foi usada intensamente por veículos, por causa do volume de trânsito." (PINTO, 2005, p. 36). Em 1925 ela foi pavimentada com concreto, tornando-se a primeira estrada brasileira (e também da América Latina) revestida com concreto.
} 
recebendo capital estrangeiro, e os ingleses foram os que mais investiram nessas obras. Tanto o material utilizado na construção das ferrovias, quanto a mão-de-obra especializada vinham da Inglaterra. Um exemplo da influência do capital inglês no Brasil é a Vila de Paranapiacaba, uma típica vila ferroviária inglesa do século XIX, onde era controlado o sistema funicular da São Paulo Railway. As casas da Vila foram construídas a partir de modelos que empregam estruturas arquitetônicas em madeira, utilizando técnicas inglesas de construção. A Vila não só foi construída dentro de parâmetros ingleses, mas também sofreu influência da cultura inglesa no seu cotidiano.

A construção da ferrovia entre Santos e Jundiaí foi iniciada em 1860, com capital inglês. Durante sua construção, o grupo brasileiro enfrentou dificuldades em cumprir com compromissos financeiros e empregar soluções técnicas que viabilizassem a obra, principalmente no trecho da Serra do Mar (GOLDENSTEIN, 1970). ${ }^{17} \mathrm{O}$ empreendimento foi entregue às mãos dos ingleses, que passaram a ter propriedade exclusiva da ferrovia, concluída e inaugurada com solenidade em setembro de 1867.

A ferrovia obteve lucros elevadíssimos, principalmente com o transporte de café e, no final do século XIX, já se mostrava insuficiente para escoar a produção paulista. Com o aumento das importações, o transporte de mercadorias pela ferrovia tornouse ainda mais crítico. Para amenizar o problema foram feitas reformas e ampliações na ferrovia entre os anos de $1896^{18}$ e 1901.

Construiu-se um novo traçado e, em 1901, foi implantado um sistema de tração ${ }^{19}$ que, combinado com o antigo funicular, operou até 1920, quando se começou a estudar uma nova substituição do sistema vigente pelo de cremalheira e aderência, no qual a locomotiva elétrica aderia aos trilhos por meio de dentes. Porém, o problema de transporte ainda persistia - agravado pelo crescimento das importações

\footnotetext{
17 Segundo a autora citada, a solução técnica utilizada na Serra do Mar pela Ferrovia foi a adoção do sistema de planos inclinados (funicular), utilizando tração por meio de máquinas fixas a cabos. A capacidade teórica máxima em cada direção seria de 1.700 .000 toneladas brutas, sendo que cada cabo funcionaria com uma carga de 60 toneladas numa ponta e 50 toneladas em outra. 0 sistema funicular era mais econômico do que o de aderência. Com relação às dificuldades de transposição da Serra do Mar, foram construídos - na chamada "Serra Nova" - 13 túneis e viadutos para a passagem da ferrovia (trecho concluído em 1866). (PERALTA, 1979, p. 51).

${ }^{18} \mathrm{Em} 1898$ a City of Santos Improvements Company construiu um ramal particular de $15 \mathrm{~km}$ de linha entre a estação de Cubatão e a região dos Pilões, no intuito de transportar papel da Companhia Fabril em Cubatão, além de transportar também passageiros, frutas, madeira e lenhas. Esse ramal contava com seis locomotivas e quarenta e cinco vagões.

${ }^{19}$ Sistema mais eficiente em tração, rapidez e volume.
} 
de petróleo, que subiam para o planalto em vagões tanque. A necessidade de melhora constante no sistema da ferrovia somada a uma situação financeira precária fez com que em 1946 o Governo Federal encampasse a companhia e emitisse títulos da Dívida Pública Federal como indenização para a Ferrovia, com juros a 7\% ao ano.

Quando foi assumida pelo Governo, a situação da estrada de ferro era péssima, e necessitava não só de recursos em dinheiro como também de inovações técnicas para continuar operando dentro de padrões aceitáveis. A partir da encampação, o nome da ferrovia mudou para "Estrada de Ferro Santos-Jundiaí", permanecendo até 1957, quando foi incorporada pela Rede Ferroviária Federal Sociedade Anônima (RFFSA) (GOLDENSTEIN, 1970). Em 1970 a ferrovia passou a pertencer à Refesa e posteriormente foi entregue à concessionária MRS Logística ${ }^{20}$, que a mantém atualmente.

\subsubsection{A cana-de-açúcar e os engenhos}

Sabemos que, na Baixada Santista, as atividades agrícolas se iniciaram com a canade-açúcar. Ferreira \& Passerani (PINTO, 2005) relatam que o primeiro pé de cana plantado em Cubatão data do ano de 1557, a pedido de Ana Pimentel - esposa de Martim Afonso. No entanto, no trabalho de Tulik (BRAGA, 1910 apud TULIK 1987) aparece uma concessão de terras feita a Antônio Rodrigues de Almeida em 1556, para que se fizessem engenhos. O relato sobre um engenho em Cubatão nos é dado através do escritor Afonso Schmidt que, descreve a construção de um engenho em 1842, a meio quilômetro da Serra, feito de pedra. A presença da

\footnotetext{
20 "A MRS Logística é uma concessionária que controla, opera e monitora a Malha Sudeste da Rede Ferroviária Federal. A empresa atua no mercado de transporte ferroviário desde 1996 quando foi constituída, interligando os estados do Rio de Janeiro, Minas Gerais e São Paulo. São $1.674 \mathrm{Km}$ de malha - trilhos que facilitam o processo de transporte e distribuição de cargas numa região que concentra aproximadamente $65 \%$ do produto interno bruto do Brasil e estão instalados os maiores complexos industriais do país. Pela malha da MRS também é possível alcançar os portos de Sepetiba e de Santos (o mais importante da América Latina). O foco das atividades da MRS está no transporte ferroviário de cargas gerais, como minérios, produtos siderúrgicos acabados, cimento, bauxita, produtos agrícolas, coque verde e conteineres; e na logística integrada, que implica planejamento, multimodalidade e transit time definido. Ou seja, uma operação de logística completa. Para desenvolver suas atividades com eficácia, a MRS trabalha com equipamentos modernos de GPS (localização via satélite com posicionamento de trens em tempo real), sinalização defensiva, detecção de problemas nas vias com apoio de raios- $X$ e ultrassom para detectar fraturas ou fissuras nos trilhos". (<http://www.mrs.com.br/interna.php?nomPagina=mapa_do_site.php\&ldSecao=0> Data de acesso: 20 de agosto de 2006.)
} 
agricultura, segundo Tulik (1987), propiciou não só uma organização do espaço, como também deu início aos "primeiros embriões rurais".

Contudo, havia plantações de cana-de-açúcar em Cubatão e nas encostas de seus arredores $^{21}$, segundo Tulik, que descreve o tipo de solo encontrado na região e a importância desse tipo de agricultura no espaço em questão:

A distribuição dos solos utilizáveis (associação aluvião argiloso-glei pouco húmido e aluvião não-argiloso) acompanha o sopé das escarpas da Serra do Mar, prolongando-se desse pé-de-serra pelos vales dos maiores rios: Cubatão, Mogi, Quilombo, Jurubatuba, Diana, Trindade, Cabuçu, Iriri e Jaguaregava. Estes tipos de solo ocorrem, ainda na base dos morros e maciços das ilhas de São Vicente e de Santo Amaro. Nessas áreas se desenvolveram as primeiras lavouras de cana-de-açúcar que, associadas aos engenhos, promovem o início da transformação da geografia humana regional. (TULIK, 1987, p. 92)

As terras que haviam sido de Rui Pinto foram consignadas por Martim Afonso, que designou o próprio Rui Pinto, Francisco Pinto e Antônio Rodrigues como fornecedores de cana para o Engenho São Jorge dos Erasmos - localizado no sopé do atual Morro da Nova Cintra, na cidade de Santos - muito próximo a Cubatão. Muitos dos gêneros alimentícios também eram cultivados em terras que não pertenciam aos donos de engenhos. Entre eles era possível encontrar arroz, café e mandioca, cultivados em fazendas localizadas nas bacias dos rios Mogi (atual Piaçaguera), Perequê e Casqueiro. (PINTO, 2005)

Esse sistema de utilização de terras para o plantio, tanto da cana quanto dos alimentos, fez parte de um sistema de organização da agricultura denominado de 'partidista', consistindo numa espécie de arrendamento ou aluguel das terras, uma vez que existia o "predomínio de grandes propriedades, possuídas mas não exploradas" (TULIK, 1987, p. 99).

${ }^{21}$ As plantações nas encostas próximas as terras de Cubatão eram de propriedade dos engenhos. (TULIK, 1987, p. 100). 


\subsubsection{A bananicultura}

O Porto Geral de Cubatão, que exercia a função de Alfândega, Posto Fiscal e Barreira $^{22}$, ficou à margem econômica desde o início das operações da estrada de ferro "São Paulo Railway Company", em 1867, que absorveu grande parte dos produtos que antes passava por Cubatão. Nesse período Cubatão passou a desenvolver a agricultura da banana. Há registro também, nessa época, do cultivo de mexericas na região de Itutinga - Pilões, além de goiabas para a produção de goiabada (PERALTA, 1979). Mas foi através das grandes plantações de banana que a cidade prosperou entre 1890 e 1950, dando empregos a muitas pessoas e chegando a sofrer escassez de mão-de-obra. A produção agrícola ganhou uma profunda expressão nesse período, reforçando ainda mais a ruralidade do local.

A história de Cubatão é marcada pela presença de elementos rurais, desde o tipo de povoamento iniciado pelos os colonos açorianos, depois com os grandes e pequenos produtores de bananas até os dias atuais, com os migrantes e alguns donos de sítios que se empenham na produção agrícola. Porém, as atividades agrícolas sempre conviveram com outras atividades, primeiro com as mercantis, e a partir da primeira década do século $X X$ até os dias de hoje, com as industriais. Verificamos também sempre presente a figura do migrante a procura de trabalho em terras cubatenses, seja para trabalhar diretamente na plantação, como os colonos açorianos, seja para trabalhar nas indústrias pioneiras (mão-de-obra que em sua maior parte se dedicava à coleta de folhas do mangue, os chamados "mangueiros") e em algumas terras, seja para trabalhar nos bananais (os camaradas) ou como observamos mais recentemente, atraídos pelas indústrias, empresas de construção, hidrelétrica e petroquímicas. Com condições de vida bastante precárias, a existência desse sujeito social acaba passando pelo contato com a terra, seja em sua história de vida passada, em seu local de origem ou mesmo em seu destino: Cubatão.

\footnotetext{
${ }^{22}$ Localizada no sopé da Serra do Mar, a barreira de Cubatão existiu durante 42 anos, entre 1835 e 1877, e fazia parte das 72 barreiras existentes na província de São Paulo, sendo uma das três de maior importância na província. Era a única caracterizada como uma Barreira de Marinha e por escoar a produção proveniente do interior paulista, sua arrecadação representava praticamente a metade dos tributos recolhidos em todas as outras barreiras. (PINTO, 2005, p. 37-39).
} 
Desde fins do século passado, fez-se a cultura da bananeira nanica, para fins comerciais na baixada litorânea santista. Foram nos arredores de Santos e São Vicente, que se plantaram, por volta de 1890 , os primeiros bananais, da espécie anã... As primeiras mudas foram trazidas das Canárias por alguns agricultores espanhóis já radicados entre nós e plantadas nas várzeas alagadiças da baixada santista-vicentina. Encontrando ali um solo propício ao seu desenvolvimento, aliado a um clima quente e úmido com pequena variação anual, a bananeira logo se espalhou pelas terras que margeiam os cursos de Cubatão, Mogi, Quilombo, Jurubatuba, Branco de São Vicente e pelas zonas ganhas ao mangue nos canais do Casqueiro e da Bertioga. (ARAÚJO FILHO, 1957 apud MEGALE, 1975, p. 29).

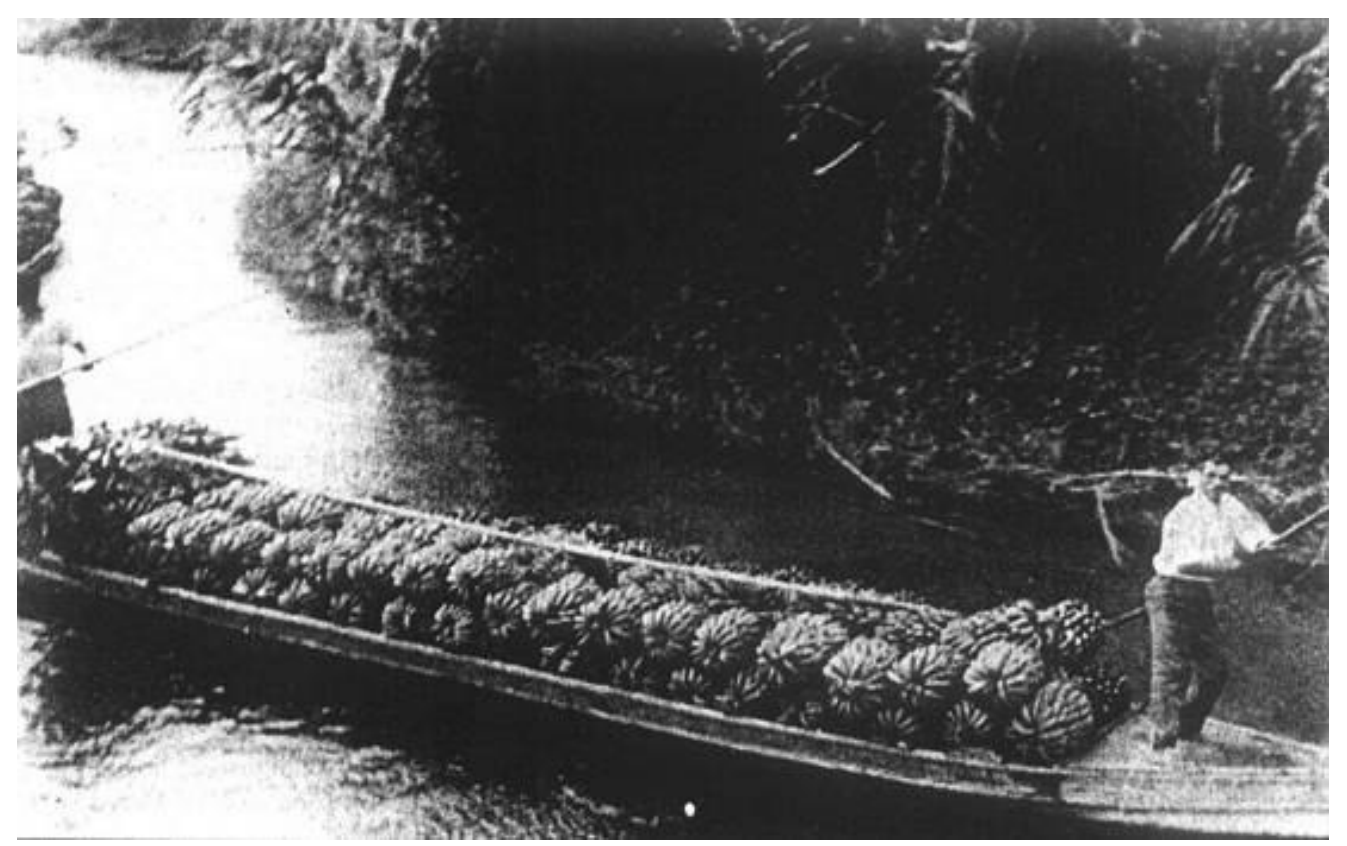

Figura 3: $O$ transporte de bananas no rio Cubatão (s/d) Fonte:<http://www.novomilenio.inf.br/cubatao/> Acesso: 26 abr. 2006

O cultivo da banana teve início em Cubatão no ano de 1890. Os sítios de banana se espalhavam ao longo da atual Via Anchieta, da estrada Cubatão-Pedro Taques e Fabril. Os trabalhadores dos sítios de bananas eram chamados de "camaradas", alguns vinham de outros estados, principalmente de Minas Gerais e da Bahia, mas em sua maioria eram caiçaras, que haviam abandonado a roça de mandioca à beiramar para conseguirem melhores condições de vida em Cubatão. Havia também os portugueses, que além de trabalharem nos bananais, extraíam areia dos rios e 
chegaram a trabalhar nos manguezais. Peralta (1979) destaca entre os trabalhadores marinheiros fugidos de bordo, soldados desertores, presos evadidos e andantes - todos iniciavam uma nova vida no novo lugar e esqueciam sua vida pregressa. Em geral, todos eram mal-remunerados, recebendo cerca de dois mil réis por dia de trabalho. Afonso Schmidt, citado por Peralta, relata que eles viviam em ranchos de palha que eram abertos, de apenas três paredes, tendo em seu centro um fogo aceso durante a noite, dessa forma, eles mantinham os mosquitos afastados. Alimentavam-se de arroz, feijão, carne seca e batata; seus cigarros eram feitos de folha de bananeira. As condições de vida desses trabalhadores, durante sua permanência em Cubatão, eram péssimas. Durante as épocas de crise da banana, eles perdiam quase tudo que haviam conseguido, passando a alimentar-se de peixes do rio Cubatão.

O trabalho nos bananais era pesado e mal remunerado. Os trabalhadores enfrentavam o calor intenso e os mosquitos causadores de malária. Muitos lotes foram doados aos trabalhadores, permitindo a fixação dos mesmos nos bananais. $A$ mão-de-obra era familiar ${ }^{23}$ e assalariada, esta em número restrito, segundo Pinto (2005) e Peralta (1979).

Segundo Peralta, desde o início do povoamento, a atividade agrícola desenvolvida pelos sitiantes em Cubatão destinava-se apenas à subsistência, prevalecendo a atividade comercial e portuária ${ }^{24}$ como principais. É claro que com o passar do tempo, alguns sitiantes começaram a cultivar e comercializar a banana, o que se tornou uma importante fonte de renda para os produtores locais ${ }^{25}$, como podemos observar:

No início do século $\mathrm{XX}$, quase todo o território cubatense era ocupado por plantações de banana que subiam pelas escarpas da Serra do Mar. A produção cresceu vertiginosamente até 1927, chegando ao auge na década de 30, sempre voltada para a exportação, principalmente para a Argentina e Uruguai. (PINTO, 2005, p. 46)

\footnotetext{
${ }^{23}$ Nos sítios trabalhavam os agricultores e suas famílias.

${ }^{24}$ No Porto Geral de Cubatão.

${ }^{25}$ No início do século XIX chegaram cinco famílias de colonos açorianos, iniciando assim o povoado de Cubatão. (COUTO, 2003, p. 17).
} 
Alguns portugueses conseguiram, com o passar do tempo, adquirir seus próprios sítios, passando a cultivar também a banana, entre outras culturas. Porém, muito trabalho foi empregado para a criação de condições de plantio em algumas áreas, como nos relata um entrevistado:

Aqui primeiro era só mangue, pântano, água. Teria num lugar ou outro um oásis, um pequenininho pedacinho de terra. Com isso, então eles tinham que fazer valetas - que chama canais hoje começando do zero. Morria dois, três metros de profundidade pra escoar a água para os rios. Água não sobe, a água só desce. Então, eles tinham que ter cuidado para estar drenando o chão. Tinham que ter cuidado quando eles fossem plantar, se desse uma ressaca, que aquela água voltaria tudo pra invadir os bananais, e se invadia, conforme invadiu, morria tudo. Então, eles começaram a pegar terreno enxuto. Geralmente eles faziam na beira de morro, na beira de serra... Então, ali era mais difícil de encontrar... Então, agora depois conforme foi surgindo a cidade, a água foi desaparecendo. Então qualquer lugar, qualquer fundo de quintal eles plantavam a banana. Naquele tempo os pobres daqui viviam a pão e banana. Todas as bananas ficavam aqui nesses morros, num lugarzinho mais alto. (Entrevistada pela autora, agosto/2005)

Entre 1925 e 1934, a exportação de bananas oriundas de Santos representava 86, $5 \%$ da porcentagem de exportação brasileira da fruta, subindo para além de $90 \%$ na década de 1970, segundo dados apresentados no trabalho de Megale (1975).

Salientamos que, entre os anos de 1925 e 1934, Cubatão ainda pertencia ao município de Santos. Portanto, na quantidade de bananas produzidas no local está também a produção da fruta em terras cubatenses.

Algumas fábricas de doces de banana também se instalaram em Cubatão na época dos bananais, além de uma fábrica de fibras de bananeiras, utilizadas em estofamentos, chamada Fibratex (PERALTA, 1979).

Em 1940, Cubatão contava com 84 produtores de banana, que empregavam mais de dois mil trabalhadores no cultivo da fruta (PINTO, 2005). Dez anos depois, o município estava entre as dez cidades que mais produziam banana no Estado de 
São Paulo (Iguape, Registro, Itanhaém, Juquiá, Miracatu, Itariri, Santos, Guarujá e São Sebastião).

Peralta relata o problema do adubo utilizado nos bananais no começo do plantio. Era utilizado o lixo coletado na cidade, o que gerou uma discussão na Câmara Municipal, em 1ำ de julho de 1949. Uns defendiam o uso do lixo, alegando que o problema do mau cheiro poderia ser resolvido com uma farta camada de terra sobre o mesmo e dizendo que o adubo oriundo do lixo teria mais calorias do que o adubo químico, visto como prejudicial, além de ser inofensivo às aves e animais que porventura viessem a ingeri-lo. Mesmo diante das vantagens expostas, o adubo orgânico foi proibido e os bananais passaram a usar adubos químicos ${ }^{26}$. Posteriormente o adubo orgânico foi também proibido de ser usado em pequenas propriedades no perímetro urbano.

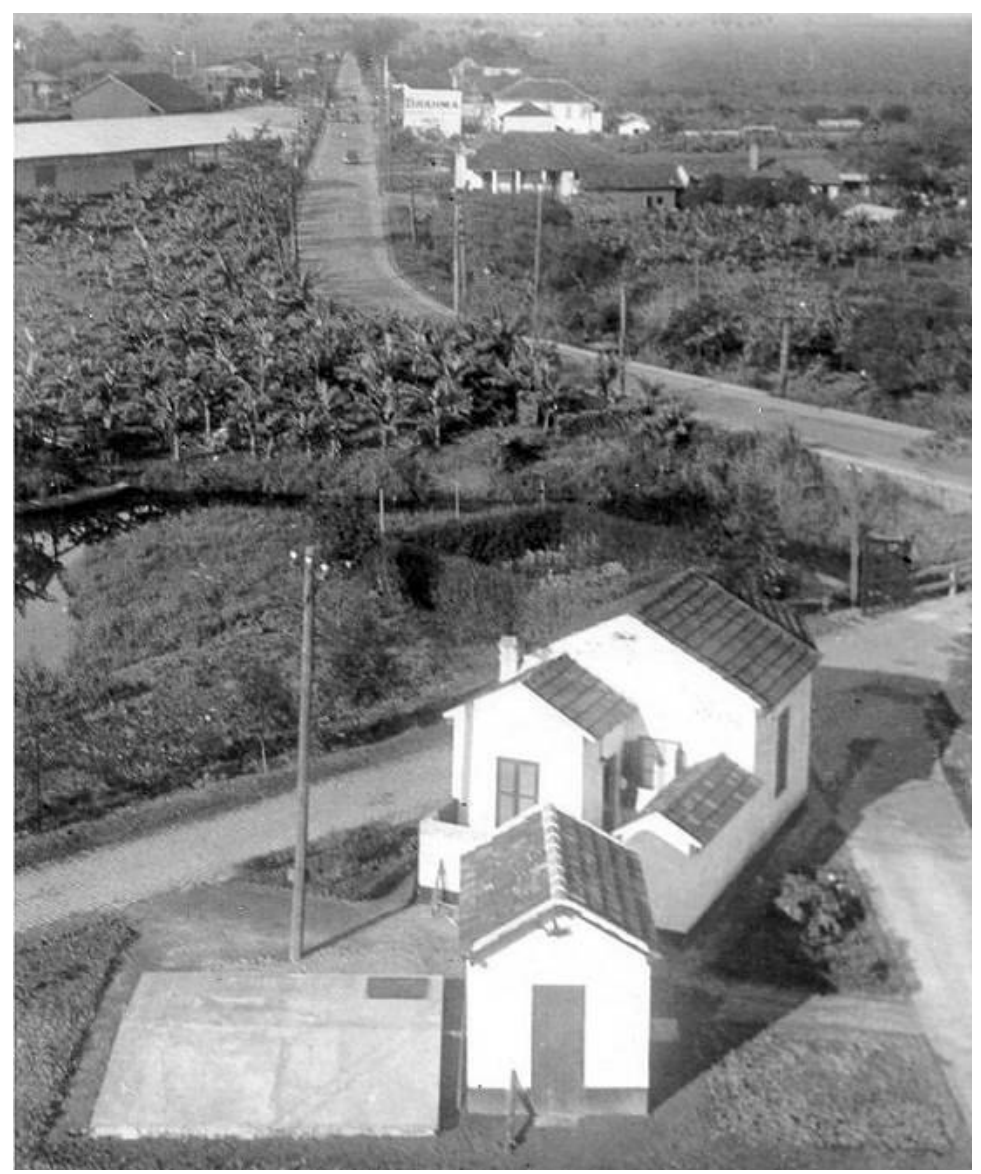

Figura 4: Foto de Cubatão em 1950.

Fonte:<http://www.novomilenio.inf.br/cubatao/> Acesso: 26 abr. 2006

\footnotetext{
${ }^{26}$ Posteriormente, o adubo orgânico teve seu uso também proibido na cidade.
} 
Mesmo na década de 1950, a paisagem ainda é bem impregnada pelas bananeiras, como podemos observar na foto acima. "Quase todos os habitantes tinham plantações em seus quintais, onde a banana era predominante." (COUTO, 2003, p. 55)

As plantações de banana se localizavam contiguamente ao aterrado de Cubatão ${ }^{27}$, espalhando-se por grande parte do território cubatense.

Desde aquela época, havia uma imbricação do campo na cidade ou uma convivência de atividades híbridas. Claro que a cultura da banana se inseria perfeitamente no contexto do acanhado município, que na época, exprimia um modo de vida tipicamente rural. Costuma-se até chamar esse período de "tempo lento" quando comparado com o do pós-50, quando o ritmo de Cubatão sofreu alterações. Vejamos o relato na obra de Pinto (2005, p. 54-55):

Tipicamente rural no modo de vida e na aparência da região, encerrado em um 'mar de bananeiras', esse período é, por vezes, chamado 'tempo lento'. Nele havia uma comunidade que Ihe dava uma feição de vila e, timidamente, proporcionava o seu desenvolvimento social e econômico. Mesmo próxima de São Paulo e Santos, essa comunidade mantinha-se isolada, seja pelas características interioranas, seja pela dificuldade de transporte da época. Tinha um subdelegado, a autoridade local, as famílias tradicionais com maior poderio econômico, fruto da bananicultura, as escolas, o lazer por meio do futebol e dos bailes ocasionais, o carnaval, a igreja e o cinema. Muitos moradores lembram desse Cubatão como uma grande família, onde havia cordialidade, apesar da vida humilde.

A autora citada destaca não só a forma que o município apresenta, com uma paisagem ruralizada ${ }^{28}$, mas faz menção, principalmente, ao tipo de relações sociais estabelecidas no local. São relações marcadas muito mais pelo caráter comunitário do que societário, dada a importância que a área rural representava para o

\footnotetext{
${ }^{27}$ A pista construída para a ligação com Santos, hoje a principal avenida da cidade, a 9 de Abril.

${ }^{28}$ Presença de sítios e pequenas propriedades próximas ao centro da cidade e até mesmo nele, com pequenas plantações ou criações de animais. E a existência de sítios de bananas. A composição era conhecida como um "mar de bananeiras".
} 
município nesse período. Os laços de amizades eram mais estreitos, com uma sociabilidade pautada por valores baseados numa ética camponesa. As festas eram verdadeiros eventos, que reuniam grande parte dos moradores. Conforme dados do censo de 1950 a população total de Cubatão era de 11.803 habitantes, sendo que 5.377 pessoas viviam na zona rural. As casas eram isoladas, e sua maior concentração se dava somente entre o Rio Cubatão e a Estação de Trem. Com poucas ruas, todas sem asfalto, predominavam os caminhos. A vida era simples e sem muitos gastos, a maioria das famílias tinha pequenas plantações, criava porcos e galinhas e pescava nos rios. O escritor Afonso Schmidt fala, em suas obras, dessa vida pacata, com traços de ruralidade. Ao contar sua infância, ele descreve o pacato local, com casas distantes umas das outras, os muros das chácaras tinham nomes humorísticos inscritos e as ruas não possuíam asfalto. Com as chuvas tudo virava um grande lamaçal, o que tornou comum o uso de tamancos ${ }^{29}$ - hábito trazido pelos portugueses. A agitação se concentrava entre a ponte sobre o rio Cubatão, o principal ponto de encontro, e a Estação de trem. O trem era o maior meio de transporte da época.

Os produtores enfrentavam flutuações de preços e dificuldades no plantio e comercialização da banana, mas a maior crise ocorreu a partir da Segunda Guerra Mundial, em 1939, quando a exportação foi prejudicada, entrando em declínio a partir de 1950. Tal queda se acentuou devido à instalação das primeiras indústrias na cidade, que atraíram a mão-de-obra que servia os bananais ${ }^{30}$, compraram muitos sítios produtores de bananas (terras valorizadas para instalação e ampliação das firmas) e poluíram o meio ambiente, o que afetou o cultivo da banana.

Os sítios que não foram vendidos tiveram suas plantações aos poucos destruídas por elementos químicos expelidos pelas chaminés das indústrias. Assim sendo muitos foram forçados a venderem suas propriedades por uma ninharia enquanto outros simplesmente abandonaram seus sítios e se dedicaram a outras atividades, em particular ao comércio. (PERALTA, 1979, p. 185)

\footnotetext{
${ }^{29}$ Por homens e mulheres.

${ }^{30}$ A atração da mão-de-obra começou com a construção da Via Ancheita, em 1942, quando muitos trabalhadores dos bananais foram trabalhar no D.E.R. (Departamento de Estradas de Rodagem). (COUTO, 2003, p. 57).
} 
Quanto ao abandono de alguns sítios por parte dos sitiantes não obtivemos maiores informações sobre a situação terras, se foram ocupadas por outros produtores ou incorporadas pelas indústrias.

No que diz respeito à situação de compra de terras pelas indústrias e a diminuição do cultivo da banana ${ }^{31}$, temos o seguinte relato:

O Brasil foi crescendo, as indústrias vieram chegando. As indústrias foram acabando com os bananais. Compravam as terras de graça. Onde tinha aquela profundidade, aterravam uns cinco, seis metros de altura, de aterro, pra pegar aquele nível. A banana sendo uma coisa corriqueira perto das outras frutas foi desaparecendo e começou a decrescer a partir de 1948, quando a Fabril começou a plantar eucalipto e as bananas começaram a enfraquecer. Ficou difícil de ver um bananal. Banana aqui era a dona e depois só aparecia no fundo das casas. Esse foi o motivo, as indústrias e o progresso fez com que os bananais fossem se extinguindo geral. (Entrevistado pela autora, agosto/2005)

A partir dessa conjuntura, Cubatão iniciaria um novo ciclo, o industrial. Mas o processo não se deu de forma passiva e pacífica. Ainda hoje, durante nosso trabalho, colhemos relatos que evidenciam o conflito entre pessoas que foram desapropriadas, indústrias e o poder público. Ainda há processos em andamento sobre essa questão. São conflitos antigos, referentes à perda de terras para as primeiras indústrias, e também atuais, que dizem respeito a alguns espaços específicos, habitados por famílias que ainda realizam atividades agropecuárias e sofrem constantes ameaças do capital, em forma de políticas estatais e/ou municipais, ou até mesmo de terceiros interessados no processo de valorização da terra. Essa situação foi discutida em várias passagens no trabalho de Damiani (1984); a autora afirma que, quando o processo de valorização da terra atinge a população, emergem os conflitos de terra com as indústrias e os pretensos proprietários diretos. Muitas falas em nosso trabalho evidenciaram esse tipo de conflito. Vejamos:

\footnotetext{
${ }^{31}$ Havia também em Cubatão outras atividades econômicas primárias: as pedreiras e os portos de areia. Localizavam-se próximos aos rios Pilões, Cubatão e Mogi. Tiveram importância no passado e, já na década de 1970, sua importância era reduzida, conforme demonstrou Peralta (1979, p. 187).
} 
Quiseram tirar a gente daqui falando que a gente tava desmatando tudo, o pessoal lá da Ambiental, mas não conseguiram! A gente ganhou na Justiça. Você vê: Há muitos anos estamos aqui plantando e agora estão falando que a gente está desmatando... (Entrevistado pela autora, julho/2006)

(...) Eu estou com um problema terrível porque eu não vou abrir mão do meu sítio, eu estou a vinte anos lá no meu sítio e não vou abrir mão pra qualquer um, não vou, eu vivo dali. (Entrevistado pela autora, maio/2006)

Eu tenho a posse da terra dada pelo juiz. Eu tenho. Agora que tem muita gente querendo me tirar de lá tem, isso tem. Já apareceu dono e quando na verdade meu sítio é uma ilha. Meu sítio é uma ilha. Só que de repentemente (sic) chegou um cara e disse que era o dono. Porque o sítio dele era do lado. (Entrevistado pela autora, maio/2006)

Porque assim, quando eu peguei lá era areia assim ó, era uma ilha de areia branca. Tinha só o lugar onde o pessoal fez os chiqueiros, né, ali onde eles criavam os porcos e o resto era o campinho da molecada. (Entrevistado pela autora, maio/2006)

Poxa, vamos determinar este sítio é esse aqui, vamos legalizar esse sítio e a pessoa vai produzir daqui, vai viver daqui”. Produz aqui. Entendeu? Porque esse é o certo. Mas não há incentivo e ainda dificulta... Poxa! Entende, a gente gosta, a gente ama Cubatão. Mas Cubatão não nos ama. Cubatão faz guerra, faz cabo-de-guerra contra a gente. (Entrevistado pela autora, maio/2006)

Peralta (1979) menciona os dados de um boletim, datado de 1973, cujo conteúdo revela que a banana era a única cultura da região, ocupando uma área de 350 hectares com cerca de 300.000 pés de fruta. E que em 1972 foram produzidas cerca de 5.500 toneladas de bananas.

No início dos anos 70, em pleno funcionamento do pólo industrial, Cubatão ainda aparece na lista de produtores do litoral com seis bananicultores e grande produção de banana nanica e nanicão. (PINTO, 2005, p. 47) 
Conforme demonstraremos posteriormente nesse trabalho, ainda hoje a cidade apresenta muitos espaços ocupados pela produção agrícola. O período em que a agricultura em Cubatão teve grande destaque contribuiu para a permanência de espaços rurais, subespaços rurais e mesmo a continuidade do modo de vida tradicional no município. São espaços que demonstram a diversidade da realidade cubatense, estando, portanto, consonante com a nossa interpretação do urbano, com base no pensamento de Henry Lefebvre.

\subsection{As primeiras indústrias e as Vilas Operárias}

De acordo com Peralta (1979), a passagem da agricultura para a fase industrial não se deu de forma abrupta, pois houve um período de atividade industrial intermediária: os Curtumes, em número bastante significativo.

Essa afirmação é feita considerando que houve uma continuidade no modo de vida da população, conforme pudemos constatar nos trabalhos consultados sobre a cidade. A predominância era do agrário, com a cultura da banana e extração do tanino dos mangues. A industrialização nesse período era pontual e pouco significativa no sentido de promover uma mudança em termos urbanísticos.

Ainda prosperava a bananicultura quando, por volta de 1910, se instalaram em Cubatão três empresas, com o intuito de trabalhar no curtimento do couro, pois na região se encontrava em abundância uma planta de nome Avicennia ${ }^{32}$. De suas folhas e cascas era retirado o tanino, matéria-prima oriunda dos mangues, com propriedade adstringente, usada na preservação do couro. Os curtumes, além de extraírem o tanino, também colhiam os troncos das árvores, que eram usados como

32 A coleta era feita por homens chamados de "mangueiros", residentes locais, em sua maioria portugueses. Eles levavam uma vida muito difícil, pois ganhavam por quilo de folha colhida. (PINTO, 2005 e PERALTA, 1979).

"Os homens ocupados nessa atividade entravam com a canoa nos alagados cobertos de mangue e derriçavam as folhas do arbusto enchendo com elas as canoas. Onde as folhas tornavam-se escassas, eles cortavam os próprios arbustos e levavam o seu carregamento para os barrancos próximos à ponte. Moravam em ranchos nas margens do rio Cubatão. Os ranchos eram abertos ou com apenas três paredes. Na frente ficava empilhada a galharia. Os troncos eram cortados em pedaços de um palmo e meio. Em seguida, tiravam a casca grossa e negra de tanino com macetes. Tudo era utilizado. A casca era vendida aos curtumes; os troncos depois de rachados ao meio, serviam de lenha para a cozinha". (SCHMIDT, Afonso. Menino Felipe, p. 59 e outras apud PERALTA, 1979, p. 77). 
lenha, utilizada em residências e fábricas, pois a região não dispunha nem de gás e nem de energia elétrica. O relato de um entrevistado quando chegou em Cubatão, em 1921, reforça essa constatação:

Então, a produção de Cubatão era de lenheiros, tirar lenha de mangue pra vender pra padarias. E como não havia gás, pra vender pro pessoal que não tinha condições de cortar lenha no mato, então eles colocavam, mediam por metro, e a pessoa chegava e comprava o metro e levava no carrinho. Mais eram "mangueiros" que tiravam lenha do mangue; e tiradores de folha do mangue, esse era o trabalho industrial, depois tinha os pescadores artesanais, porque eles pegavam uma rede qualquer e jogavam num cantinho assim, ninguém tinha dinheiro pra comprar peixe, em todo lugar tinha peixe aqui. Era só botar uma isca e pegava logo um. (Entrevistado pela autora, agosto/2005)

O período de funcionamento dos curtumes foi curto; eles iniciaram suas atividades por volta de 1910, e deixaram de existir na década de 1940. Tanto os curtumes quanto os engenhos e as olarias podem ser considerados indústrias de pequeno porte, pioneiras em Cubatão (PERALTA,1979). Posteriormente, outras três indústrias de médio porte se instalaram em terras cubatenses: a Companhia Curtidora Marx, em 1912, a Companhia J.B. Duarte ${ }^{33}$, em $1916^{34}$ e a Companhia Fabril de Cubatão, em $1922^{35}$.

$\mathrm{Na}$ primeira metade do século $\mathrm{XX}$, a fixação da mão-de-obra foi um problema enfrentado pelas primeiras indústrias instaladas na região, e também pelos bananais, pois o calor era intenso, o clima era úmido, os mosquitos incomodavam bastante, e as doenças, como a malária, afugentavam os trabalhadores mais corajosos e necessitados (PERALTA,1979 e DAMIANI, 1984). O relato de um entrevistado fala um pouco dessa situação na década de 1940, já com as primeiras pequenas fábricas instaladas:

\footnotetext{
33 Também mais conhecida por Cia. de Anilinas, Produtos Químicos e Material Técnico.

${ }^{34}$ A data de sua fundação foi, segundo Peralta (1979), o ano de 1914. Porém, o ano em que a companhia iniciou suas atividades não é mencionado na citada obra. Encontramos no trabalho de Couto (2003) o início das atividades referente ao ano de 1916, conferindo com a data mencionada por Pinto (2005). No trabalho de Léa Goldenstein (1970) a existência da fábrica não é sequer mencionada como uma das indústrias pioneiras.

${ }^{35}$ Data em que entrou em operação.
} 
Vim para cá com 3 e estou com 81. A história, eu conheci demais. Por exemplo: Eu posso dizer pra você, que eu vi, eu acompanhei a história de Cubatão. Cubatão é um velho povoado e um novo município. Cubatão pertencia a Santos. Santos nem apreciava Cubatão porque aqui só dava malária. Aqui só dava bicho-de-pé, aqui só dava cobras, aqui só dava sarampo. Aqui só dava caxumba, febre amarela. Cubatão era objeto de preconceito racial.

Antes da poluição já era tudo poluído. Poluído com miséria, com racismo. Eu, por exemplo, quando eu trabalhei aqui na Anilinas e fui com as mãos amarelas. Mandaram que eu fosse tirar uma carteira modelo 19 - que hoje é a identidade. Então aquela moça que foi pegar na minha mão, minha mão tava amarela, ela pensou que eu tivesse com icterícia, hoje vocês chamam de hepatite. Ela não queria pegar na minha mão, pra colocar naquela pranchinha.

Aqui quando eu cheguei havia poluição de miséria, de sofrimento. Não havia médico. Aqui você tinha que tomar um lombricóide, um copo deste tamanho, uma medida de óleo de rícino que dava no Centro de Saúde, aí você saía correndo pra desovar o que tinha de verme, que existia, no caso. Porque você ficava inchadão de lombriga, você comia e não ficava satisfeito. (Entrevistada pela autora, agosto/2005)

\subsubsection{Companhia Curtidora Marx e a Vila Colônia}

Localizada no antigo bairro da Olaria, que margeava Via Anchieta, a Companhia Curtidora Marx se instalou em Cubatão no ano de 1912. No entanto, sua origem data de 1895, quando abriu seu escritório em São Paulo. Seu dono era um alemão nascido em Stuttgart, chamado Wilhelm Marx (pai do paisagista Burle Marx), que residiu em Cubatão entre 1904 e 1914. Para Peralta (1979), essa companhia era, na época, o maior curtume do Estado de São Paulo. Porém, com a eclosão da Primeira Guerra Mundial, ela encerrou suas atividades, visto que seu dono era um alemão. Em 1914, a companhia passou para as mãos da família pernambucana Fernandes Ribeiro, que não conseguiu equilibrar suas finanças e a repassou a seu maior credor: London \& River Plate Bank Limited. Este a colocou à venda em 1918. Domingos da Costa Moniz, português e dono de uma das maiores importadoras de 
couro do Brasil, cuja família era proprietária de uma empresa de carruagens em Portugal, efetuou a compra da companhia. Era o chamado "curtume". Em 1929, seu nome foi alterado para Curtume Domingos da Costa Moniz. Ela começou a funcionar nesse mesmo ano curtindo couros e peles, mas, com a crise de 1929, ele resolveu transferir sua fábrica de cadarço e pontas de arreio, localizada no Bairro do Brás, em São Paulo, para Cubatão.

O curtume era movido a vapor, utilizando uma caldeira alemã. Até 1919 a luz era de lampião a querosene, e depois passou a ser fornecida pela City of Santos Improvements \& Co. Ltda.

Com a extração intensa da Avicennia, a matéria-prima tornou-se escassa, porém a Costa Muniz a utilizou até 1950 (PERALTA, 1979) - com relação a isso há controvérsia. A utilização também de material sintético na curtição do couro é mencionada nos trabalho de Couto (2003) e de Pinto (2005).

Uma nova crise, causada pela Segunda Guerra Mundial, abalou as atividades da companhia. A Domingos da Costa Muniz paralisou seu curtume, adquiriu nova maquinaria e iniciou a produção de mangueiras contra incêndios, produto em falta no mercado interno, que, com as dificuldades de importação, passou a ser o produto principal da companhia. Mais tarde ela instalou uma seção de borracha, e em 1945 mudou seu nome para Costa Muniz Indústria e Comércio S.A. A companhia diversificou mais uma vez sua produção, fabricando fios de tecidos, correias e cordas de couro curtido, além de cordões de sandálias e sapatos.

A curtição do couro exigia mão-de-obra experiente, o que dificultava o recrutamento por parte do empregador, mesmo porque a população local era também escassa. Isso levou à contratação de técnicos provenientes de outras procedências. Mas as condições locais também não ajudavam: o ataque de mosquitos, o calor excessivo, a umidade e doenças como a malária eram sempre as causas de desistência do trabalho. Só aos poucos a companhia foi conseguindo estabelecer um quadro de funcionários $^{36}$ (eles eram em 83 no ano de 1963) adaptados ao local e também treinados na curtição do couro. (GOLDENSTEIN, 1965 apud COUTO, 2003). Essa situação pode ser observada nos relatos de Peralta (1979, p. 79): "as doenças locais

\footnotetext{
${ }^{36}$ Havia também muitas funcionárias, embora em número reduzido.
} 
dificultavam a existência de um trabalho regular; houve ocasiões de falta de cerca de $40 \%$ dos operários devido ao surto da malária".

No entanto, prezava-se pelas boas condições de trabalho dos operários. A firma oferecia muitos benefícios aos seus funcionários: preparava antecipadamente algumas festas (como as festas juninas, o dia de reis e o Natal) e construiu uma Vila Operária, conhecida como "Colônia", que chegou a ter 150 casas, 23 barracões que abrigavam a grande maioria de seus funcionários - e uma capela em homenagem a São Pedro. As festas eram organizadas e financiadas pelo dono da firma, fato que chamou a atenção de Peralta (1979). Essas festas, segundo a autora, deixaram de existir na época de sua pesquisa, fazendo assim parte do passado da empresa, porém sem menção de data de seu encerramento. A empresa funcionou até 1981, quando foi decretada sua falência.

Posteriormente, com a construção da Estrada Cubatão-Pedro Taques a Vila Operária desapareceu. (DAMIANI, 1984)

A relação entre essa e as outras empresas, ou mesmo com a região da Baixada Santista, é praticamente nula, segundo Goldenstein (1970), ela manteve-se totalmente isolada. Sua produção era encaminhada para a matriz, localizada em São Paulo, onde era feita a comercialização dos respectivos produtos. No entanto, com a instalação da Companhia Fabril de Cubatão, ela passou a obter desta, feltro usado empregado na estampagem do couro (COUTO, 2003 e PINTO, 2005). De qualquer forma, seu isolamento parece incontestável.

\subsubsection{Companhia J. B. Duarte e a Vila Química}

Essa companhia, bem maior do que a Costa Muniz, foi fundada em 1914 por José Batista Duarte, que possuía também uma fábrica de adubos em São Paulo.

A história de aquisição do terreno onde se instalou essa firma é bastante peculiar. Conforme o depoimento de um ex-funcionário da firma, José Duarte esteve no ano de 1913 em Cubatão para adquirir o terreno e, como não havia conseguido, resolveu almoçar na única pensão existente na cidade, de propriedade de Dona Miquelina. Esta, ao saber da situação de S. Duarte, dispôs-se a vender um terreno a ele. E foi, 
então, nesse terreno comprado de Dona Miquelina que S. Duarte instalou a fábrica (PERALTA, 1979).

Situada no centro de Cubatão, onde hoje fica a atual Avenida Nove de Abril, a companhia foi inaugurada em 1916, quando entrou em operação, recebendo o nome de Fábrica de Produtos Químicos e Corantes Santa Cléo ${ }^{37}$, fabricando, inicialmente, apenas três produtos: tanino, adubos e corantes. Em 1923 a empresa tinha 100 funcionários e construiu, como a Costa Muniz, uma Vila Residencial que possuía 20 casas. Com o passar dos anos ela foi ampliando sua produção, tornando-se a maior fabricante de anilinas, fosfato, sabão, carbonatos e silicatos. A companhia chegou a possuir filiais em muitos estados brasileiros, porém, em 1930, passou a ter grandes dificuldades financeiras, sendo então vendida em 1933 ao empresário alemão John Jurgens e renomeada de Companhia de Anilinas e Produtos Chímicos do Brasil com matriz localizada no estado do Rio de Janeiro. A empresa conseguiu novamente impulsionar seu crescimento e, um pouco antes de começar a Segunda Guerra, adquiriu outros terrenos, o que garantiu a expansão da fábrica e a ampliação de sua Vila Residencial, construindo barracões para abrigar os operários solteiros, e montando um centro recreativo e uma quadra de esportes. Sua área passou a compreender um grande terreno, do centro da cidade até o Rio Cubatão em cujas margens a companhia chegou a construir um trampolim para lazer dos funcionários. "Nos terrenos da Cia. Anilinas havia um sítio com exploração de laranja, banana, limão, entre outras frutas, além de um belo eucaliptal, hoje no local está o Jardim São Francisco." (FERREIRA \& PASSERANI, 2005, p. 46)

Logo então, percebemos uma espécie de prolongamento, por parte da empresa - e de certa forma de seus funcionários - de uma paisagem característica do local, que eram sítios, chácaras com plantações de árvores frutíferas, além de uma preocupação com o lazer, principalmente no que envolvia a natureza circundante.

Nesse período de crescimento, a empresa chegou a ter 13 filiais e representantes no exterior; e empregava, só em Cubatão uma média de 200 funcionários ${ }^{38}$. Trabalhar lá era sinônimo de status, pois os empregadores eram extremamente exigentes com

\footnotetext{
${ }^{37}$ Recebera esse nome, segundo Couto (2003, p. 33), em homenagem à esposa de S. José Duarte.

${ }^{38}$ Também com um número inferior de mulheres (10) compondo seu quadro de funcionários.
} 
a mão-de-obra ${ }^{39}$, o que, segundo a firma era imprescindível ao seu bom funcionamento. A exigência em relação aos técnicos e químicos era ainda maior. Segundo os moradores locais, ela pagava os melhores salários, além de distribuir cestas natalinas após o balanço anual. A visita do dono da firma, que morava no Rio de Janeiro, era sempre motivo de festa e alegria (PERALTA, 1979).

Em 1937, ela mudou de nome novamente, e passou a ser denominada Companhia de Anilinas, Produtos Químicos e Material Technico (COUTO, 2003) ou Companhia de Anilinas e Produtos Químicos do Brasil (PERALTA, 1979).

Com a Segunda Guerra, o fornecimento de matéria-prima pela Nacco-National Anilin and Chemical Corporation, uma empresa americana foi interrompido. E, em 1942, todos os alemães da Anilinas foram levados como prisioneiros para São Paulo. Então, a Companhia Anilinas passou a ser administrada por um interventor ${ }^{40}$. Dois anos depois, seu número de funcionários foi reduzido para 80 . Entre os anos de 1942 e 1954, a companhia foi dirigida por interventores e tutores de John Jurgens, falecido em 1944, que a deixaram numa péssima situação financeira e técnica. Em 1954, ao atingirem idade de assumir a companhia, os filhos de John contavam apenas com centavos em caixa. A situação levou a companhia "a se desfazer de algumas terras... e doar outras para que a Prefeitura abrisse novas ruas." (COUTO, 2003, p. 35)

Um dos filhos de John se casou e seu sogro se encarregou de administrar os negócios. O outro filho detinha apenas $1 / 4$ da propriedade e não interferia nas decisões do irmão. Embora fosse um período difícil, a empresa dava muitas festas e chegou a construir duas piscinas e um clube recreativo. Os funcionários, segundo Peralta, viveram uma época de muita euforia e alegria.

(...) foi uma época de alegria e euforia, pois as festas eram constantes. O diretor da firma proporcionava, a funcionários e conhecidos, inúmeras festas e banquetes.

\footnotetext{
39 O pertencimento ao quadro de funcionários era feito através de recomendação pessoal de funcionários da firma. (PERALTA, 1979)

${ }^{40}$ Esse interventor não demonstrava interesse pelo progresso da empresa, e segundo Peralta (op. cit, p. 86) a mesma ficara "praticamente acéfala".
} 
A Vila residencial vivia dias festivos. A construção de duas piscinas, do clube recreativo - atual Clube Guimarães - atestam esses dias gloriosos, num certo contra-senso ante os problemas econômicos que se acumulavam. (PERALTA, 1979, p. 86)

Diante das dificuldades, a companhia foi parando aos poucos. Em 1964 ela deixou de pagar seus funcionários. No ano seguinte, em plena ditadura, eles decidiram entrar em greve. A greve teve grande repercussão nos meios políticos da região e na imprensa santista. A conjuntura da empresa à época levou-a a encerrar suas atividades com falência decretada em 1966, com um quadro de apenas 52 funcionários, e indo a leilão judicial em $1967^{41}$. Em 1973, as casas da vila residencial foram desocupadas e posteriormente derrubadas. Hoje, no local da antiga "Química", como a companhia era conhecida, a prefeitura do município construiu um parque, chamado Parque Municipal Anilinas, localizado na Avenida 9 de abril, no centro.

\subsubsection{Companhia Fabril de Cubatão e a Vila Fabril}

A história da Companhia Santista de papel começou em 1903, quando uma indústria de papel localizada no município de Caieira decidiu ampliar seu negócio, e construir uma nova unidade em outro município. Algumas características locais, como a quantidade de água limpa, imprescindível na produção de papel, disponível e sem a necessidade de um tratamento prévio; o aproveitamento da cachoeira do rio Pilões, caso fosse necessário a construção de uma usina hidrelétrica, a disponibilidade de terras e finalmente a proximidade do Porto de Santos, foram fatores fundamentais na escolha da cidade de Cubatão.

E em 1914 deu-se início à construção da companhia no município de Cubatão, à margem esquerda do Rio Cubatão. A empresa comprou uma área de 2.400 hectares localizada na raiz da Serra do Mar, entre os morros do Pai Matias e da Mãe Maria, acima dos Pilões. Nessa mesma região, a The City of Santos Improvements Company Limited captava água para o fornecimento de energia elétrica para a área

\footnotetext{
${ }^{41}$ As instalações foram divididas em 107 lotes. (COUTO, 2003).
} 
de Santos. No local foram construídas uma usina hidrelétrica e algumas instalações para os funcionários responsáveis pela manutenção da mesma.

A construção foi iniciada com um maquinário importado da Alemanha, porém, com o advento da Primeira Guerra Mundial, as atividades foram interrompidas e retomadas somente em 1918, já com um novo sócio: Theodomiro de Mendonça Uchoa, um fazendeiro de Ribeirão Preto, que se juntou ao então proprietário, advogado e fazendeiro de Campinas, e fundou com ele a Companhia Fabril de Cubatão.

Em 1919, a empresa adquiriu um sítio localizado em freguesia de Nossa Senhora do Rosário Aparecida, em Cubatão, pertencente à família do escritor Afonso Schmidt, da família Brunkenn, onde havia pequenas plantações. Nesse novo local, a empresa montou a fábrica e, em suas imediações, foi construída uma Vila Residencial, com escola e capela - onde eram realizadas as missas de domingo. Em 1932, a vila já contava com 130 casas. Ela era ampliada conforme crescia a mão-de-obra solicitada pela companhia. Em 1941, entro dela já havia padaria, refeitório, armazém de secos e molhados, bar, barbearia, sapateiro, pensão, um pequeno cinema, farmácia, clube e até um chalé de jogo de bicho (PEREIRA, 1988 apud COUTO, 2003), um campo de futebol e 200 casas (PINTO, 2005) ${ }^{42}$. Em 1963 a vila abrigava 75\% dos funcionários da companhia e suas respectivas famílias. Além da vila, foi também construído um depósito para uso da empresa.

Entre as duas áreas da fábrica, usina e vila-fábrica, foi construída uma pequena ferrovia, para facilitar a comunicação entre ambas. Além dela, havia uma outra linha utilizada pela empresa, uma extensão da linha férrea da Companhia City de Santos, atualmente inexistente, que passava pela fábrica e terminava na Estação de Cubatão, por onde passava a Estrada de Ferro. O trem trazia celulose importada da Noruega, Finlândia e Suécia, e voltava com os papéis já confeccionados pela empresa. A maior parte da matéria-prima era importada, mas a fábrica também utilizava eucalipto, pinho, fibras de bananeiras, capim, palha de arroz, papéis velhos e trapos. Os itens produzidos eram: papel, papelão, papéis para embrulho, papel

\footnotetext{
42 Segundo essa autora "com toda essa estrutura, a Vila Fabril tornou-se muito mais do que um simples bairro operário". No trabalho de Peralta (1979) a Vila correspondia às exigências de seus habitantes, com todos esses serviços, além de serviço médico. Tudo isso foi bem sustentado até a década de 50.
} 
higiênico, papel para jornal e para impressão. Na década de 30, a companhia chegou a fabricar serpentina, utilizada nos blocos carnavalescos da própria Vila.

Com a eclosão da crise de 1929, a empresa paralisou suas atividades, indo a leilão. E, em 1932, ela passou para as mãos da Companhia Santista de papel, que industrializava e comercializava papel, que fez várias reformas, habilitando-a para utilização de matéria-prima nacional, dadas as dificuldades de importação. $\mathrm{Na}$ época, a empresa ocupava uma área de mil alqueires de terras, com um quadro de 585 funcionários $^{43}$. Nesse mesmo ano, a fábrica enfrentou problemas com a produção do papel e também um surto de malária. Uma das soluções encontradas para conter o surto foi criar um serviço de coleta de lixo na Vila.

No ano de 1944, a empresa adquiriu novas terras. Ela comprou um grande sítio que fazia parte do sítio chamado de "Cubatão de Cima", como o outro sítio comprado em 1919 - também pertencente à família Brunkenn, ao senhor José Antônio de Almeida Amazonas. Tal propriedade incluía benfeitorias como plantações, matas, capoeiras, casas de moradia, cocheiras, casas para operários, pocilgas, entre outras. As novas terras também trouxeram grandes problemas para a empresa, como falta de documentos de posse, área cadastrada como Reserva Florestal, no bairro da Água Fria, ${ }^{44}$ e construções irregulares.

No começo, tanto a lenha das matas (na área pertencente à indústria), quanto as águas das cachoeiras e do rio Cubatão eram usadas como combustível. Mas, em 1947, no período pós-guerra, frente às dificuldades de importação, a empresa decidiu produzir sua própria celulose. Ela plantou cerca de um milhão de pés de eucalipto em sua propriedade, mas não obteve êxito. E, resolveu então, adquirir celulose do Sul de Minas, do Paraná e de Santa Catarina, além da importada. Com o surgimento de outras indústrias de papel no Brasil, a empresa passou algumas dificuldades, mas em 1950, ela recebeu um novo diretor que a reestruturou e impulsionou novamente a produção.

\footnotetext{
${ }^{43}$ Desses, cerca de 10 a 15\% eram mulheres. (PERALTA, 1979).

${ }^{44}$ Com relação a essa gleba da Água Fria, os problemas foram: proibição de efetuar limpeza na tubulação que levava água para a Vila e a proibição de retirada de pedras e terra arenosa, que havia sido vendida à Companhia Siderúrgica Paulista. A Cosipa teve os vagões com essa mercadoria apreendidos, sendo obrigada a fazer a reposição do material.
} 
E em 1967, a companhia foi comprada pelo grupo Ripasa S/A - Celulose e Papel, que passou a deter $93,83 \%$ do capital da Santista de Papel. A celulose passou então a vir da Ripasa de Americana, no estado de São Paulo. Em 2002, a empresa empregava 358 trabalhadores diretos e 150 indiretos (COUTO, 2003, p. 39). Posteriormente, o Grupo Votorantim Celulose e Papel S.A - (VCP) passou a ter participações relevantes na Ripasa, cuja metade do capital está nas mãos da Votorantim. Hoje, os produtos da Ripasa são divididos igualmente entre a VCP e o Grupo Suzano, seu sócio no negócio.

\subsubsection{Usina Henry Borden e a Vila Light}

Novas fontes de energia já estavam sendo procuradas pela São Paulo Light and Power Company Limited ${ }^{45}$ desde 1911, porém, só em 1923, ela conseguiu um projeto que propunha a criação de uma grande usina hidrelétrica, sob a responsabilidade do engenheiro Asa White Kenney Billings.

Em 1925, o estado de São Paulo enfrentava uma crise energética decorrente da redução de precipitações e do aumento do consumo de energia. Diante dessas circunstâncias, a empresa começou a realizar estudos com o objetivo de encontrar soluções viáveis para o fornecimento de energia no estado. Iniciando assim, um racionamento no fornecimento de energia e a construção da Usina de Cubatão, cujas obras foram iniciadas em abril de 1925. Aproveitando a escarpa da Serra do Mar, com um desnível de 720 metros, e uma das regiões de mais alta precipitação do Brasil - onde se localiza a cabeceira do Rio das Pedras, a abundância de chuvas na região e os recursos hídricos do planalto paulista (represas, estações elevatórias, canais, túneis e tubulações) ${ }^{46}$, o engenheiro Billings propõe a instalação da Usina em Cubatão ${ }^{47}$.

\footnotetext{
45 Essa empresa iniciou suas atividades no Brasil no início do século XX (1901), explorando transportes coletivos, e fornecendo iluminação em 1911. (PERALTA, 1979).

${ }^{46}$ Engloba parte do médio Tietê, o canal do rio Pinheiros e os reservatórios da Represa Billings (1927) e do rio das Pedras. (ELETROPAULO, 1996 apud COUTO, 2003)

${ }^{47}$ Não encontramos nenhum tipo de referência (dos autores consultados) com relação à aquisição do terreno onde foi construída a usina.
} 


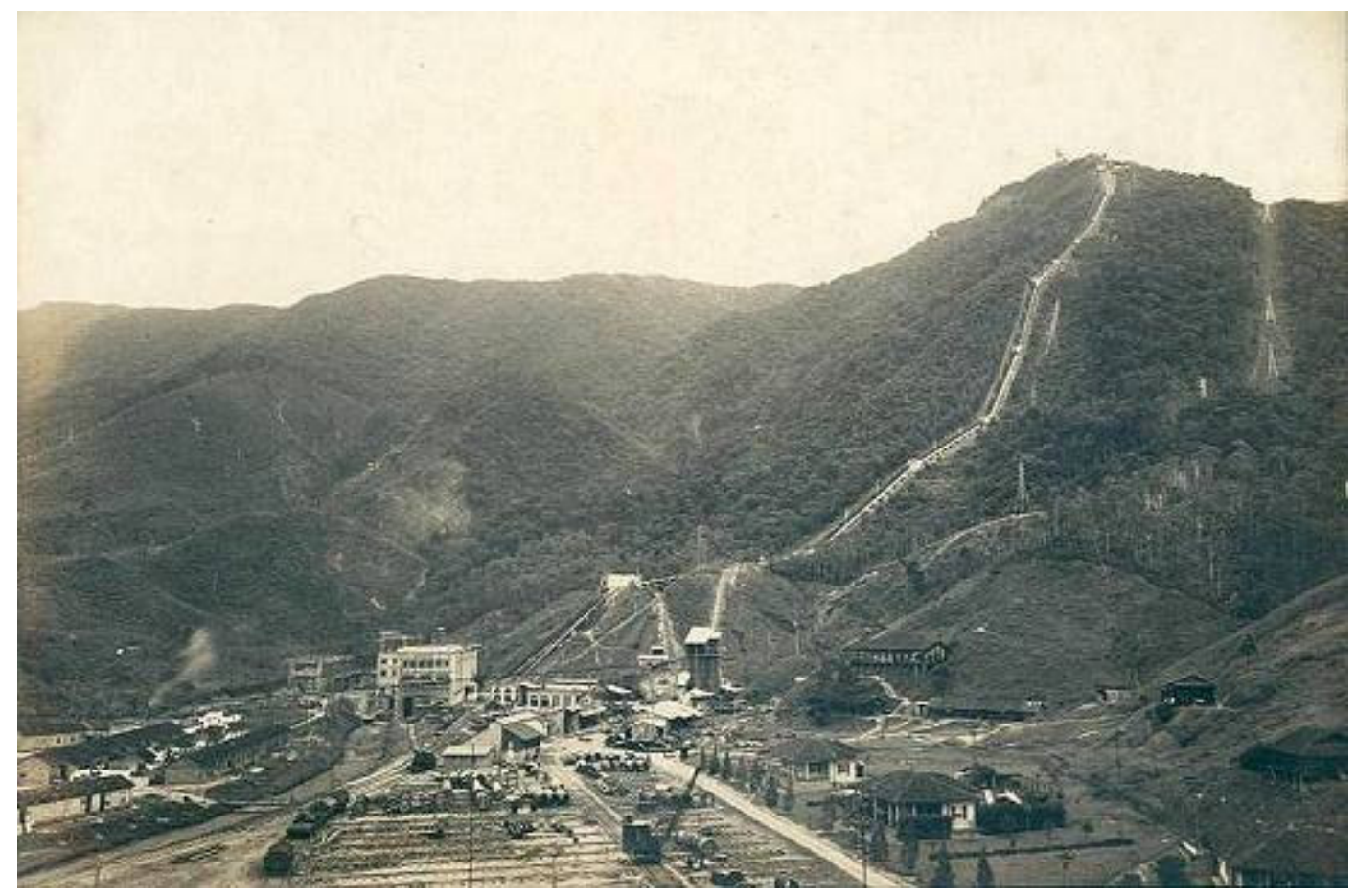

Figura 5: Instalação da Usina Henry Borden. Ao fundo observamos a escarpa da Serra do Mar com as tubulações descendo até a Usina Externa (construção alta à esquerda). Do lado direito vemos três casas de funcionários.

Fonte:<http://www.novomilenio.inf.br/cubatao/> Acesso: 26 abr. 2006

O maquinário da usina era importado e chegava pelo porto de Santos. Para facilitar seu transporte até o local da construção da usina, a São Paulo Railway construiu uma linha férrea ${ }^{48}$ entre a Estação de trem de Cubatão e o terreno da usina.

Durante as obras, enfrentou-se o problema da malária. Para tratar da questão, a companhia contratou o sanitarista Arthur Leiva, que havia combatido a doença durante a construção do canal do Panamá.

Após dezoito meses de construção, no dia 12 de outubro de 1926, a usina entrou em operação com duas turbinas com capacidade de 44,347 kW. Mesmo com algumas ampliações através da construção de novas adutoras, a capacidade da Usina já não atendida a demanda de energia em 1946, dado o crescimento de São Paulo e o consumo aumentado principalmente pelas indústrias. Frente à impossibilidade de ampliar a usina em sua parte externa, devido aos constantes deslizamentos, que e já eram motivo de preocupação quanto à segurança da usina, estudos demonstravam que as condições geológicas apresentadas pelo esporão da Serra do

\footnotetext{
${ }^{48}$ Desativada tempos depois.
} 
Mar eram favoráveis à construção de uma usina subterrânea a um custo menor do que sua ampliação externa. A maior das obras certamente foi a construção da usina subterrânea, iniciada em 1952 e concluída em 1961. Foi escavado um túnel blindado em aço dentro da rocha da Serra do Mar, com 3,25 metros de diâmetro interno e 1.506 metros de comprimento - que passou a receber as águas do Rio das Pedras. Esse túnel termina numa grande caverna, com altura de 38,6 metros, largura de 20,5 metros e comprimento de 120 metros. As águas que passam pela usina subterrânea são lançadas no Canal de Fuga que deságua no Rio Cubatão; com seis geradores de $65.000 \mathrm{~kW}$ cada um e turbinas Pelton, a usina aumentou sua capacidade de produção de energia para $887,4 \mathrm{~mW}, 467,40 \mathrm{~mW}$ provenientes da usina externa e 420,00 mW da usina subterrânea, "sendo responsável por cerca de $14 \%$ da potência energética instalada no país e $80 \%$ a $90 \%$ da produção total de energia do Estado de São Paulo. Era, simplesmente, o maior conjunto gerador em operação no Brasil." (RADESCA, 1965 apud COUTO, 2003, p. 43). A partir de 1964, a usina recebeu o nome de um funcionário canadense que havia ocupado o mais alto cargo executivo da Light ${ }^{49}$ entre 1946 e 1965, passando a se chamar então: Usina Henry Borden.

A mão-de-obra utilizada no funcionamento da Usina era bem reduzida: 86 empregados. Para abrigar os funcionários (operários, operadores, técnicos e chefes), em 1927, iniciou-se a construção de 100 casas junto à Usina, a Vila Residencial da Light. No começo eram casas de madeira e folhas de zinco, depois foram erguidas casas de boa qualidade, cuja construção variava conforme a época e o nível do funcionário a que se destinava - algumas casas chegaram a ser entregues com mobília. A Vila é em estilo canadense, bem arborizada, com cerca de 224 casas.

\footnotetext{
${ }^{49}$ A partir de 1967, a companhia passou a ser denominada de Light - Serviços de Eletricidade S/A.
} 


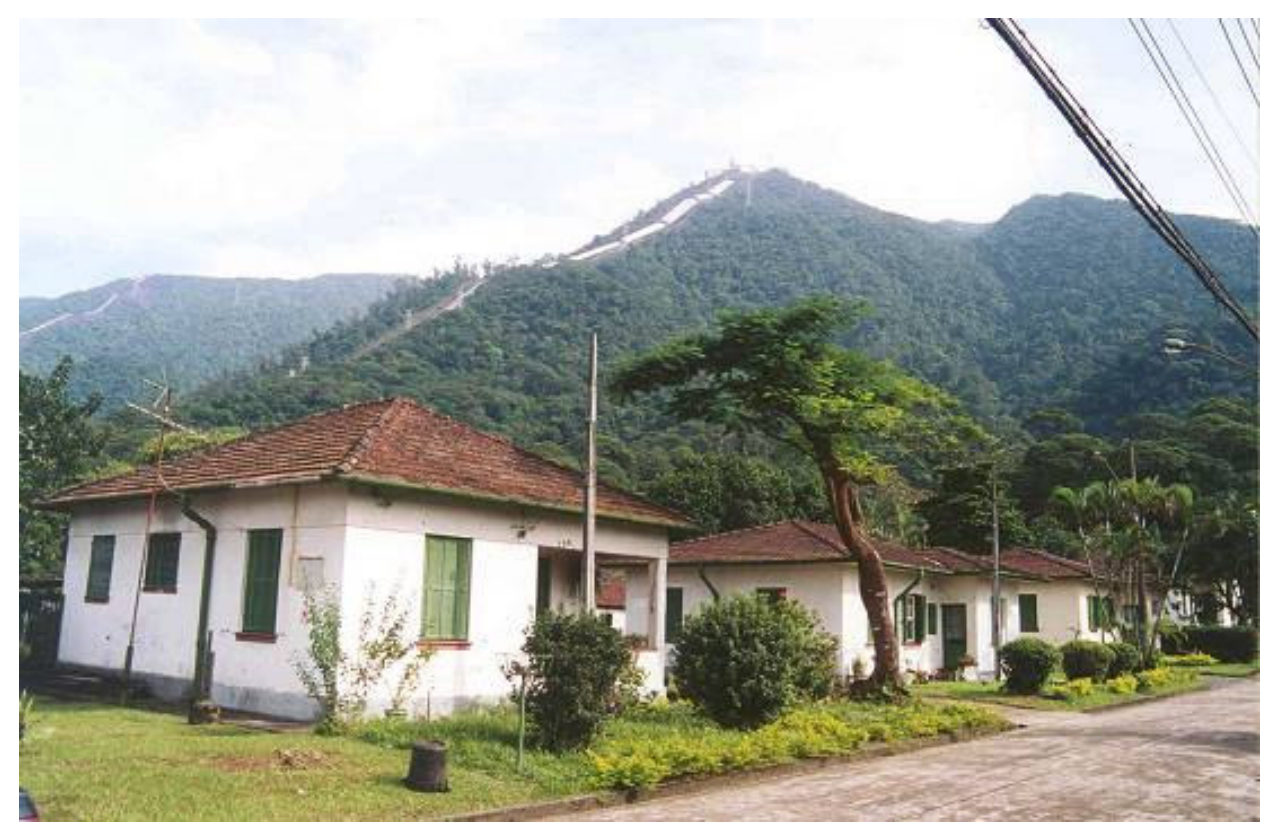

Figura 6: Casa de engenheiro situada na Rua Paraná na Light. Fonte:<http://www.novomilenio.inf.br/cubatao/> Acesso: 26 abr. 2006

Além das casas, foi construído um pequeno hospital, com quatro médicos e um pequeno consultório dentário - todos de uso exclusivo dos funcionários. A Vila contava ainda com um campo de futebol, um pequeno playground, um clube, uma cooperativa de funcionários (uma espécie de mini mercado), uma escola de Ensino Fundamental $^{50}$, hoje mantida pela Prefeitura do Município, e um Jardim de Infância. A continuidade dos estudos, na maioria das vezes, era feita nas escolas de Santos. Para esses alunos, e também para aqueles que, mesmo dispondo da estrutura educacional oferecida pela empresa na Vila, preferiam estudar em escolas em Santos, a empresa fornecia um microônibus para o transporte dos alunos.

Com o represamento de uma pequena cachoeira que desce a Serra e passa por ali, uma pequena piscina natural, bastante utilizada pelas crianças da Vila foi construída.

Os moradores sempre iam às festas na Fabril, pois uma vez que a Light era de origem anglicana, as festas religiosas não eram celebradas ali. Eles participavam de festas natalinas, de páscoa e do aniversário da empresa. Nessas ocasiões era freqüentemente oferecido um almoço ou um churrasco.

${ }^{50}$ Desde 1936, iniciando com três séries e depois em 1974 até a quinta série e finalmente em 1976 até a oitava série (atualmente esses ciclos correspondem ao Ensino Fundamental). 
A Associação Atlética da Usina de Cubatão chegou a desenvolver atividades sociais e esportivas. No entanto, a Vila manteve, e ainda mantém, uma relação restrita com a população de Cubatão, ficando, de certa forma, bem isolada tanto física quanto socialmente - ao contrário das outras Vilas de Cubatão (Costa Muniz, Fabril e Anilinas), que com o tempo tornaram-se pontos de atração e lazer (PERALTA, 1979).

Além das quatro Vilas já citadas, existiram também mais três Vilas: uma situada no sopé da Serra do Mar, onde moravam os funcionários da alfândega - que impediam o contrabando do café pelo Caminho do Mar; a Vila Sopé, próxima a ela, e, finalmente, a Vila de Piaçagüera ${ }^{51}$, que comportava algumas casas e fazendas de bananicultores.

Na década de 1980, a Vila da Light já contava com uma pequena agência bancária, e foi mencionada em muitos trabalhos como quase auto-suficiente, dada a sua estrutura.

A Light, para Peralta (1979), foi a primeira indústria a provocar alterações profundas na região, em termos sócio-econômicos, uma vez que passou a fornecer energia elétrica a todas as outras indústrias que posteriormente se instalaram ali. De certa forma, ela contribuiu para a implantação do parque industrial. Com a instalação da usina, as águas do rio Cubatão aumentaram consideravelmente, ganhando velocidade.

Segundo Peralta (1979), a construção da Usina atraiu uma grande massa de trabalhadores $^{52}$ (em geral provenientes de São Paulo, Rio de Janeiro e Minas Gerais, regiões onde a Light já possuía usinas de energia elétrica), que foram despedidos após o término da obra, trazendo problemas para o município de Cubatão.

A Light, seguida por duas dezenas de indústrias, foi responsável pelo desencadeamento de um aumento populacional desenfreado, num município despreparado para receber levas e mais levas de

\footnotetext{
${ }^{51}$ Inclusive nesse local foi construída a Cosipa.

52 "No início, foram empregados seis mil trabalhadores, entre os do planalto e os do sopé da serra, em Cubatão, e mais 300 empregados de escritório." (PINTO, 2005, p. 53)
} 
migrantes, originários de todos os Estados do Brasil, em especial dos mais atrasados, criando traumas sociais cada vez mais difíceis de serem solucionados. (PERALTA, 1979, p. 100)

Com a construção da usina subterrânea, novos operários ${ }^{53}$ foram "despejados" na cidade. Além de iniciar o processo de uso e descarte de mão-de-obra, criando o "peão de trecho" (PERALTA, 1979), e o disponibilizando no popularmente conhecido "mercado de escravos" 54 , a usina também foi a primeira a utilizar acampamento para operários em Cubatão, onde os trabalhadores moravam durante a execução das obras e muitas vezes permaneciam lá mesmo após seu término.

Essa situação de descarte de mão-de-obra e moradias improvisadas tornou-se freqüente em Cubatão - fato que mereceu destaque no estudo apresentado por Damiani (1984) sobre a relação entre industrialização, favelas e trabalhadores na cidade de Cubatão.

Em 01 de abril de 1981, a companhia foi estatizada, mudando o nome para Eletropaulo - Eletricidade de São Paulo S/A, porém com a privatização das empresas distribuidoras de energia, a mesma passou, em 1998, a ser administrada por outra estatal denominada EMAE - Empresa Metropolitana de Águas e Energia $\mathrm{S} / \mathrm{A}$, subordinada à Secretaria de Energia (PINTO, 2005) ${ }^{55}$.

${ }^{53}$ Estes já eram de outra procedência: de Sergipe, do Rio Grande do Norte, da Paraíba e de Pernambuco.

${ }^{54}$ Tanto sobre o peão de trecho quanto o mercado de escravos, ler Damiani (1984).

${ }^{55 ،} \mathrm{Em}$ 1956, a companhia reestruturou-se tendo por base a Brascan Limited e foi nacionalizada com a publicação do Decreto Federal no 40.440, de 28/11/56. Em 1979, o governo brasileiro, através da ELETROBRÁS, adquiriu da Brascan o controle acionário da então LIGHT - Serviços de Eletricidade S.A.. Em 1981 o Governo do Estado de São Paulo adquiriu parte do sistema da LIGHT constituindo a ELETROPAULO - Eletricidade de São Paulo S.A., autorizada pelo Decreto Federal № 85.839, de 24/03/81, a funcionar como concessionária de serviços públicos de energia elétrica, com a finalidade básica de assumir a operação dos sistemas de geração, transmissão e distribuição nos municípios de concessão da LIGHT no Estado de São Paulo.Em 05/07/96, foi promulgada a Lei Estadual no 9.361, que criou o Programa Estadual de Desestatização - PED, dispondo sobre a Reestruturação Societária e Patrimonial do Setor Energético Paulista. Com a aprovação do Conselho Diretor do PED, a partir de 01/01/98 a ELETROPAULO foi cindida em quatro empresas independentes: EMAE Empresa Metropolitana de Águas e Energia S.A., Eletropaulo Metropolitana - Eletricidade de São Paulo S.A., EBE - Empresa Bandeirante de Energia S.A e a EPTE - Empresa Paulista de Transmissão de Energia Elétrica S.A.

Com a cisão, coube a EMAE exercer as operações de geração de energia elétrica antes conduzidas pela Eletropaulo. Através da Resolução no 72, de 25/03/98, da Agência Nacional de Energia Elétrica ANEEL, Ihe foram transferidos os direitos de exploração de Serviços Públicos de Energia Elétrica." (http://www.cesp. com.br/site_emae/empresa/historico.asp) 
A Vila ainda existe, mas a maioria das casas está vazia e abandonada. Segundo os moradores, existe a possibilidade de que elas sejam vendidas, sendo dada preferência aos atuais moradores e funcionários da empresa, outra hipótese levantada é o tombamento das mesmas.

\subsubsection{Lazer e Festas}

A vida social na Vila Operária da Fabril era bastante intensa, principalmente no que se referia às festas. Muitas delas eram organizadas por festeiros e atraíam pessoas de todo o distrito de Cubatão. O destaque ficava por conta das festas religiosas ${ }^{56}$, comemoradas com comidas específicas, como as festas juninas, além de grandes procissões até a Vila Light. Outra festa bem animada era o carnaval comemorado com serpentina fornecida pela própria empresa; o "Bloco dos Cabeçudos", inspirado na Festa de Bom Jesus de Pirapora lembrava também os bonecos nordestinos de Pernambuco. Este era o bloco mais famoso, levando o título de campeão do carnaval santista em 1937 e 1938.

$\mathrm{Na}$ época, o lazer em Cubatão estava muito associado às condições oferecidas pelo local, como a natureza, por exemplo. Havia os passeios de barca e os banhos no rio Cubatão, bem como as pescarias, famosas pela diversidade de peixes encontrados.

Mesmo com as atividades acima descritas, Peralta (1979) ressalta que Cubatão era uma vila muito acanhada, e muitos estrangeiros que ali trabalhavam se sentiam isolados. Esse fato também é mencionado por Couto (2003, p. 40):

(...) tanto a Cia. Santista como a Costa Muniz eram distantes do centro de Cubatão e, assim, viviam quase isoladas com suas vilas operárias. A vocação econômica do povoado continuou a ser a bananicultura.

Para Lefébvre, festa representa a manifestação da espontaneidade, enquanto lazer é um conceito criado pela sociedade do trabalho alienado, que precisa designar um momento especial para o trabalhador se recuperar do desgaste do trabalho. Ainda que o lazer seja interpretado como um momento de reprodução da força de trabalho,

\footnotetext{
${ }^{56}$ Principais festas religiosas: São Pedro, São João, Nossa Senhora da Lapa e São Lázaro.
} 
necessário do ponto de vista do capital, ele pode transcender sua gênese e se transformar num momento da espontaneidade, da fruição e da manifestação do desejo. O caráter popular e simbólico está presente no tipo de lazer usufruído pela população daquela época em Cubatão. Mesmo que fosse promovido pelo empresário, desfigurando a contradição entre trabalho e capital ${ }^{57}$, as festas e o lazer ganham movimento próprio de uma manifestação cultural.

${ }^{57} \mathrm{~A}$ aparência de uma comunidade real com base na identidade não contraditória entre capital e trabalho eram comuns nesses espaços proletarizados cativos, segundo Damiani (1984). 


\section{Capítulo 2. Industrialização e Urbanização}

\subsection{A Via Anchieta}

O aumento do tráfego na estrada "Caminho do Mar", ligando o Planalto a Santos, causava problemas no fluxo de circulação de veículos na Serra do Mar, colocando mais uma vez a necessidade de melhoria das respectivas vias ou mesmo a construção de uma outra estrada. Foi então que, através do decreto 7.162 de maio de 1935, foi autorizada, pelo governo do Estado, a construção de uma nova rodovia ligando São Paulo a Santos. No entanto, o projeto só foi definido em 1937, determinando a construção da Via Anchieta seguindo o curso do rio das Pedras. Nesse mesmo ano, foi inaugurado o trecho da Estrada de Ferro Sorocabana, partindo de Santos, cortando São Vicente em sua área continental e respectivamente Cubatão, porém sem nenhuma estação.

E em 1939, a pedra inicial da construção da Via Anchieta foi, finalmente, colocada, mas, as obras começaram apenas em 1942. Uma grande faixa de terras cubatenses foi doada pela Companhia Santista de Papel para sua construção. Essas terras se estendiam desde as margens do rio Cubatão até o alto da Serra. Inaugurada a sua pista ascendente, em abril de 1947, já se podia transpor a Serra em apenas 13 km.

As características do Cubatão antigo e rural começaram a mudar em 1947, com a construção da Via Anchieta. A nova estrada ocupava justamente uma região de sítios de bananas, hortas e pomares, que tiveram de ser destruídos, alterando em definitivo a paisagem local. (PINTO, 2005, p. 67).

Para a autora acima citada, a construção da Via Anchieta alterou o mapa da região, tornando Cubatão uma cidade descontínua.

A movimentação dos carros tornou-se um atrativo para os moradores da Vila Fabril; e a ida a São Paulo foi imensamente facilitada. A pista adentrava a cidade, cortandoa pela sua principal avenida, onde se localiza a Avenida 9 de Abril. Logo o transporte rodoviário ganhou destaque, antes conferido à Estrada de Ferro Santos-Jundiaí. A passagem pelo centro da cidade continuou até 1950, quando o governador Adhemar 
de Barros inaugurou o trecho construído entre o rio Casqueiro e a entrada do povoado, isolando um pouco a cidade do tráfego intenso de veículos - fator que já preocupava os habitantes, devido a questões de segurança. Conforme notícias da época, Cubatão voltava a ter a calma com a qual estava habituada, enfim, ao "modo de vida cubatense" (A TRIBUNA, 16/07/1950 apud COUTO, 2003, p. 48).

A segunda pista só foi inaugurada cerca de 6 anos mais tarde, em 1953. No pico da obra (geral) calcula-se que foi necessário o emprego de três mil homens. Entre os desafios da construção estava a malária, vencida finalmente em 1944, a partir de ações firmadas entre o Departamento de Estradas de Rodagem (D.E.R.) e o Departamento de Combate às Endemias Rurais.

A Via Anchieta possui 58 viadutos, 18 pontes e 5 túneis. Posteriormente, foi construída a Rodovia dos Imigrantes, e recentemente, sua segunda pista, denominada de "Nova Imigrantes".

As estradas não foram criadas em função das necessidades de Cubatão, mas visando primeiramente atender às necessidades de circulação de produtos entre Santos e São Paulo e, somente mais tarde, passariam a ter relação também com o centro produtivo de Cubatão. Damiani (1984), Peralta (1979) e Goldenstein (1970).

\subsection{As grandes indústrias}

Já apresentando características construídas historicamente, que facilitariam uma industrialização mais expressiva, a cidade de Cubatão foi escolhida para abrigar o maior Pólo Petroquímico da América Latina durante a fase de industrialização da economia brasileira, iniciada pela política nacionalista do Presidente Getúlio Vargas (1930 a 1945), Ocupado no desenvolvimento do país a partir da indústria. Em 1950, a área já contava com a Estrada de Ferro Santos-Jundiaí, a Via Anchieta, água em abundância e áreas grandes e "livres" (passíveis de apropriação), além da proximidade com o Porto de Santos e com a cidade de São Paulo (PERALTA, 1979). Essa infra-estrutura ficou ainda mais completa com a instalação da Usina Henry Borden, em 1926, que poderia fornecer energia para o pólo industrial. O governo brasileiro passou então a apoiar as chamadas indústrias de base, produtoras de matéria-prima para outras indústrias, financiando sua abertura e 
intervindo na economia, no intuito de tornar o Brasil menos dependente do mercado mundial. A decadência da cafeicultura no Brasil e o prejuízo das importações causado pela Segunda Guerra Mundial também foram fatores importantes na adoção de uma postura desenvolvimentista por parte do governo.

O país passava por grandes transformações diante da política de substituição das importações, que visava a produção de produtos até então adquiridos no exterior, como por exemplo, máquinas e ferramentas. Com a política nacionalista, o Estado passou a ser o grande financiador da abertura de indústrias.

Durante o governo de Olívio Gaspar Dutra (1946-1950) a política de industrialização foi interrompida, sendo retomada novamente por Getúlio Vargas em 1951. Vale lembrar que a formação do pólo industrial de Cubatão ocorreu logo após sua emancipação política, em 1948, portanto, ainda durante o Governo Dutra. (PINTO, 2005).

O Conselho Nacional de Petróleo decidiu, em 1949, construir uma Refinaria em Cubatão, possibilitada pela criação do BNDES (Banco Nacional de Desenvolvimento Econômico e Social) - no intuito de financiar a modernização do país e o programa de crescimento econômico, em 1952.

A firma norte-americana Hidrocarbon Research se encarregou de elaborar o projeto da Refinaria. O plano desenvolvimentista contou também com capital estrangeiro de bancos e empresas. No trecho que segue, Damiani destaca o papel do Estado, mas reconhece a acumulação do capital como preponderante nesse processo.

Que o Estado seja o principal demandante é inteligível, considerando-se a sua importância no capitalismo monopolista de modo geral, enquanto agente econômico inclusive, e particularmente, em casos de países dependentes, como o Brasil. (DAMIANI, 1984, p. 41)

O governo Juscelino Kubitschek deu continuidade à política de Getúlio, intensificando-a com o chamado "Plano de Metas", que visava a aceleração da industrialização. Porém, com recursos limitados, o governo abriu o mercado brasileiro para a instalação de indústrias estrangeiras, época conhecida como de "internacionalização da economia" (PINTO, 2005). Essa internacionalização 
prosseguiu em Cubatão até 1980, quando economia brasileira foi afetada por grandes dificuldades e os problemas ambientais tornaram-se mais evidentes. Mesmo assim, a alta produção teve continuidade; apenas o pólo industrial, com crescimento constante até então, teve seu crescimento desacelerado, em face das novas exigências de preservação ambiental.

A Refinaria ${ }^{58}$ de petróleo Presidente Bernardes ${ }^{59}$ teve suas obras iniciadas em junho de 1952 e em 1953 passou a integrar o patrimônio da Petrobrás, criada no mesmo ano com o objetivo de monopolizar o petróleo. No dia 16 de abril de 1955 a refinaria iniciou suas atividades. Propiciando, através de sua grande produção de derivados de petróleo, a instalação de indústrias petroquímicas na cidade como, por exemplo, a Copebrás (1955), a Alba (1957), a Petrocoque, a Ultrafértil e a Companhia Brasileira de Estireno (1957). A partir dessa época, Cubatão passou a receber "uma avalanche de sergipanos, paraibanos, pernambucanos e migrantes do Rio Grande do Norte jamais vista." (PERALTA, 1979, p. 05)

Inicialmente, a Refinaria seria instalada na cidade de Santos (SP), mas a grande disponibilidade de terras em Cubatão a menor custo, sua instalação foi feita em terras cubatenses em janeiro de 1950, no sopé da Serra do Mar. No entanto, segundo o estudo apresentado por Goldenstein (1970), a Refinaria seria instalada no Rio de Janeiro, mas por razões de segurança, o Conselho de Segurança Nacional não concordou com a escolha. Resumindo, a decisão sobre a implantação da Refinaria em Cubatão foi de cunho político, com base em razões de ordem estratégica, atendendo a interesses de grupos econômicos de São Paulo.

Esse processo de implantação da Refinaria não ocorreu sem conflitos. Houve resistência dos sitiantes para disporem de terras para a sua construção:

\footnotetext{
${ }^{58}$ É sabido que uma refinaria representa uma das manifestações mais espetaculares do capitalismo moderno. As grandes sociedades petrolíferas do mundo - e nelas está incluída a PETROBRÁS constituem enormes concentrações de capital, baseadas, na maioria das vezes, numa integração industrial e comercial que inclui pesquisa, exploração, transporte, refinação e distribuição dos produtos refinados. (GOLDENSTEIN, 1970).

59 A refinaria recebeu o nome de Refinaria Presidente Bernardes de Cubatão (RPBC) em "homenagem ao presidente Arthur Bernardes, grande incentivador da criação da Petrobrás e que havia falecido dias antes". (PINTO, 2005, p. 92).
} 
Os sitiantes negavam-se terminantemente a dispor de suas propriedades, que eram sua fonte de subsistência e representava seu meio de vida, seu habitat. (PERALTA, 1979, p. 115)

As terras adquiridas pela Refinaria foram compradas de diferentes proprietários e, quando havia algum entrave, a mesma se valia de desapropriações executadas pelo Governo Federal, segundo Goldenstein (1970), foram feitas cerca de 68 desapropriações.

Não só sítios e fazendas foram ocupados, mas houve também o deslocamento de algumas construções, como o Cemitério Municipal, o Cruzeiro Quinhentista ${ }^{60}$ e a Capela de São Lázaro, abrindo a área para a instalação da Refinaria.

Segundo Damiani (1984), baseada em dados da Prefeitura do Município, em 1979, a área das principais indústrias em Cubatão era de $4.199 .485 \mathrm{~m}^{2}$ (só a Petrobrás ocupava nesse período cerca de 3.497.199 m²). Segundo a autora, a apropriação das terras não se deu de uma só vez, na década de 70 , as indústrias continuavam adquirindo fazendas e sítios.

A segunda grande indústria instalada no município operava na área de siderurgia: A Companhia Siderúrgica Paulista (Cosipa) foi fundada em 23 de novembro de 1953 com capital privado. Embora o local da construção da siderúrgica já houvesse sido escolhido, o terreno de 420 hectares na Piaçagüera foi adquirido apenas em 1956. No local havia uma vila de casas de ferroviários, próxima a uma estação de trem, que contava com uma pequena escola e um imenso bananal com a casa do proprietário da fazenda. O terreno pertencia a Adelino da Rocha Brites. A produção no local era tão grande que, em 1958, ainda havia grande quantidade da fruta na área da Cosipa.

O projeto da Cosipa foi elaborado por uma empresa americana chamada Kaiser Engineering Company, e visava, além da construção da empresa, a construção de um porto marítimo, para a recepção de matéria-prima importada dentro da usina, barateando o transporte. Como o solo era constituído de argila orgânica, isto é, mole

\footnotetext{
${ }^{60}$ Construção feita em homenagem a primeira fase do Caminho do Mar, atual Estrada Velha. Originalmente se localizava no cruzamento do antigo Caminho do Padre José de Anchieta e o Caminho do Mar.
} 
e de baixa resistência, eles tiveram que construir um chão artificial utilizando 130 mil estacas, além de dezenas de canais de drenagem. Isso elevou muito o custo da construção, obrigando o governo do Estado a financiar parte do projeto (PINTO, 2005, GOLDENSTEIN, 1970; DAMIANI,1984).

A construção da usina foi iniciada em 1959, e em 1963 ela contava com 16 mil trabalhadores. A usina começou a funcionar em 31 de março de 1966, utilizando 300 engenheiros treinados; por ano são quase 12 mil funcionários, diretos e indiretos. Em junho de 1963, a Cosipa passou a se chamar Usina José Bonifácio de Andrada e Silva, em homenagem ao patriarca da Independência. A construção do porto marítimo foi vetada pela Companhia Docas de Santos, que concedeu a autorização somente em 1964. (PINTO, 2005).

Durante o governo Collor, em 20 de agosto de 1993, a Cosipa foi privatizada.

Hoje, o pólo industrial de Cubatão está dividido em quatro setores: petroquímico, químico, siderúrgico e de fertilizantes. Existe ainda a produção de energia e papel.

O pólo industrial se manteve com várias empresas estatais até 1990, quando se iniciou o processo de privatização. Grandes empresas como a Cosipa, a Ultrafértil e a Eletropaulo foram privatizadas no período.

Conforme mapa da Aplan, da Prefeitura do Município de Cubatão, existem hoje 24 indústrias em Cubatão. São elas:

EMAE (Light), Grupo Votorantim, Ultrafértil-Fosfertil (CB), Ultrafértil-Fosfertil (Piaçagüera), Companhia Brasileira de Estireno, Refinaria Presidente Bernardes, Tedep (Refinaria Presidente Bernardes), Basan (Refinaria Presidente Bernardes), Petrocoque S/A, Carbocloro S/A, Rhodia do Brasil Ltda, Engeclor Ltda, AGA S/A, Dow Brasil S/A, IFC indústria de Fertilizantes Cubatão, Engebasa Mec. e Usinagem S/A, Cargil Fertilizantes, White Martins, Benzoato do Brasil Ltda, Columbian Chemicals (Copebrás), Hidromar Indústria Química Ltda, Bunge Fertilizantes S/A (duas unidades), Companhia Siderúrgica Paulista (Cosipa), Painco, Brastubo e Dufer. Cerca de 17 grandes empresas ocupam locais de antigos bananais.

As indústrias cubatenses produzem, em sua maioria, matériasprimas intermediárias para outras indústrias, em especial as de São 
Paulo e região Sudeste, e também exportam para várias partes do mundo. (PINTO, 2005, p. 83)

Cubatão é a única cidade brasileira a reunir uma usina hidrelétrica, uma siderúrgica e uma Refinaria de petróleo em seu território (PINTO, 2005). E, a partir de 04 de junho de 1968, Cubatão foi declarada como área de segurança nacional, através da lei ํo. 5449, sendo seu prefeito nomeado a partir de então pelo Presidente da República, chamados de interventores ou "prefeitos biônicos" (DAMIANI, 1984). Até essa data Cubatão teve eleições regulares, depois as eleições foram suprimidas e o povo votava apenas para vereador.

A autonomia do município, estabelecendo o poder Legislativo, Executivo e Judiciário foi conseguida através da Resolução no. 01 do Tribunal de Justiça do Estado de São Paulo, em 29 de dezembro de 1971. E sua autonomia política foi adquirida em 15 de maio de 1985, através da Emenda Constitucional №. 25, estabelecendo eleições para prefeito naquele mesmo ano. Cubatão tem, como lei de maior expressão municipal, a Lei Orgânica, aprovada em 1992, que define a estrutura e a organização municipal. Já em 14 de junho de 1998 foi promulgado o Plano Diretor do Município, que orienta o desenvolvimento físico da área urbana. Desde 1949, data de sua emancipação, Cubatão teve 16 prefeitos (PINTO, 2005).

\subsection{Especificidades do processo de industrialização e urbanização em Cubatão}

Conforme Goldenstein (1970), a colonização em Cubatão se iniciou com a concessão das sesmarias em 1819, quando 23 famílias passaram a habitar o local ${ }^{61}$. $\mathrm{Na}$ época, havia poucas casas, além de ranchos para tropeiros e estalagens construídas em pedra. Em 1825, o número de casas em Cubatão de 38, segundo Hércules Florence (s/d apud PERALTA 1979), e em 1852 já se podia encontrar algumas casas ao longo do rio Cubatão.

\footnotetext{
${ }^{61}$ Esse fato foi exposto no 1‥ Capítulo desta dissertação.
} 
Durante a mudança dos Portos $^{62}$, mudava também o povoado. Com a construção do Aterrado, em 1827, ligando o sopé da Serra à Santos, Cubatão passou a ter um novo posto fiscal denominado de barreira ${ }^{63}$. Portanto, a organização desse espaço foi direcionada pelas necessidades do capital e apresenta aspectos claros da intervenção da ordem distante. Grandes investimentos foram feitos com a finalidade de fornecer bases para a instalação das indústrias. As estradas e os meios de transportes foram muito importantes nesse processo.

A ferrovia São Paulo Railway teve grande impacto na economia nacional, pois possibilitou a exportação do café e também de outros produtos secundários, através do porto de Santos, levando a cidade a se consolidar como grande porto escoador do café brasileiro, base de nossa economia desde a $2^{\mathrm{a}}$. Metade do século XIX (PERALTA, 1979). O êxito de Santos e de São Paulo através do uso da ferrovia levou Cubatão (porto de pé de Serra) a decair. Primeiramente, ele perdeu o Registro, depois a Barreira e, finalmente, a partir da inauguração da ferrovia, todas as transações comerciais entre a Província de São Paulo e Santos. Nessa época se desenvolveu o cultivo extensivo da banana ${ }^{64}$, embora iniciasse algumas atividades industriais com três empresas: a Companhia Curtidora Marx, em 1912; a Companhia Anilinas, em 1916; e a Companhia Fabril de Cubatão, em 1919.

Seja convivendo com atividades mercantis (como função de porto e posto fiscal) ou com atividades industriais, as atividades agrícolas sempre estavam presentes, portanto podemos dizer que Cubatão foi fortemente marcada pela presença de elementos rurais.

Cubatão, de 1890 até 1950, recebeu muitos trabalhadores destinados à colheita de tanino nos mangues, ao trabalho nos bananais e também nas três indústrias pioneiras - o que não significou uma mudança na forma e na dinâmica do município, embora com as primeiras indústrias tenham surgido as Vilas Operárias.

\footnotetext{
62 Há registro de três portos fluviais em Cubatão: O Porto Piaçaguera (utilizado primeiramente pelos índios, em funcionamento até 1560), logo depois veio o Porto das Almadias ou Armadias e, por último, entre 1600 e 1650, o Porto Geral de Cubatão.

${ }^{63}$ Nessa época o povoado ficou conhecido como Barreira do Cubatão.

64 Iniciada em 1890 e chegando ao auge na década de 30. (PINTO, 2005, p. 46).
} 
As Vilas surgiram muito da necessidade de solucionar o problema da fixação e controle da força de trabalho necessária à produção em Cubatão, dado que a malária, os mosquitos e o calor excessivo afugentavam os trabalhadores que vinham trabalhar nos bananais, nas empresas ou em construções. David Harvey (1979 apud DAMIANI, 1984), trata dessa questão como sendo uma intromissão direta dos capitalistas no local de moradia dos trabalhadores, com o intuito de moldar tal trabalhador, já no seu local de moradia, visando adequá-lo às exigências do local de trabalho. As Vilas, salvo na ocasião das festas, se mantinham praticamente isoladas, tendo em alguns casos, certo grau de autonomia, devido à estrutura que dispunham, como empório, farmácia, etc. A cidade nesse aspecto se apresentava fragmentada.

Tais fragmentos são interpretados por Damiani (1984) como espaços "proletarizados cativos", onde, sob a aparência de uma comunidade real, estariam baseados na identidade contraditória entre trabalho e capital, eliminando, de certa forma a zona de tensão. A situação de relativo isolamento desses locais, ainda que sob a influência do controle do capital (sob a ordem clientelista e patrimonialista), já revela o início da constituição de um espaço fragmentado permeado por um conjunto de elementos de ordem simbólica que remetem a um ritmo de vida próprio de pequenas comunidades.

Autores como Damiani (1984), Couto (2003) e Cohn (1985, apud COUTO, 2003) afirmam que, entre os anos 1930 e 1950, época em que o capital industrial estava em sua fase de expansão no Brasil, e o modelo agroexportador estava sendo substituído pelo modelo urbano-industrial, curiosamente, Cubatão não recebeu nenhum novo estabelecimento industrial. Portanto, Cubatão sofreu um processo intenso de industrialização, recebendo capital privado nacional, internacional e estatal, somente após 1950. Conforme Damiani (1984, p. 13) esclarece, Cubatão:

(...) atinge novos ramos de produção, estratégicos no que diz respeito à composição das esferas produtivas capitalistas da economia nacional. Em outros termos, torna-se um centro de produção de bens de capital, mais exatamente, de bens de capital circulante, desenvolvendo os setores petroquímico e siderúrgico, fundamentalmente.

Segundo Peralta (1979), até a construção da Via Anchieta, iniciada em 1942 e concluída em 1947, Cubatão se caracterizou como "núcleo estagnado, com poucas 
perspectivas de desenvolvimento", com um nível de arrecadação considerável, porém sem nenhuma expressão política (isso até 1948 - data de sua emancipação política).

O pouco crescimento ocorrido se deu essencialmente à margem direita do Rio Cubatão em direção à cidade de Santos, enquanto que à margem esquerda se instalou a zona industrial, próxima à encosta da Serra. Na opinião de Goldenstein, talvez essa localização se deva ao fato de que ali havia terras mais firmes ou, pelo menos, material para fazer aterros. Isso porque a cidade encontra-se no pé-deserra, em terras baixas constituídas por terrenos sedimentares de formação recente, que são cortados por uma rede de drenagem desordenada. Mesmo assim, segundo Goldenstein e Damiani, foi necessário fazer o aterramento do terreno de mangue e a modificação do solo para a instalação das indústrias.

Por estar em posição estratégica e por apresentar condições geográficas favoráveis, a cidade de Cubatão sofreu grandes modificações pós-1950. Damiani relata que sua posição geográfica foi produzida historicamente, primeiro com investimentos no transporte rodo-ferroviário e posteriormente com o aproveitamento da escarpa da Serra do Mar, o que possibilitou a geração de energia, através da Usina Henry Borden, para as indústrias que ali se instalaram. A proximidade de Santos e São Paulo completou os requisitos para Cubatão se tornar um local privilegiado para a instalação do pólo industrial. A esses fatores soma-se a intervenção do Estado ${ }^{65}$ como facilitador do empreendimento, e a abundância de água e de terras, muitas compradas a baixos preços e produto de desapropriação.

Muitos conflitos de terra surgiram nesse segundo período, relativos à luta e posse de terrenos. Os processos, desde 1950, se arrastam até hoje. Simultaneamente, a queda nas exportações de bananas atrelada à poluição oriunda das indústrias comprometeu as plantações levando à venda de propriedades a essas mesmas indústrias - o que Damiani chama de "poluição estrategicamente conveniente", como forma de desvalorização das terras que precisavam ser negociadas. Isso afugentou os trabalhadores melhor remunerados ${ }^{66}$ e alguns sitiantes atemorizados

${ }^{65}$ O Estado sempre esteve presente nesse processo, como na construção e manutenção da malha rodo-ferroviária.

${ }^{66}$ Uma ínfima parcela acabou se dedicando ao comércio. 
com possíveis perdas. Os agricultores se encontravam em situação econômica instável: flutuações de preços da banana e todas as dificuldades de plantio, colheita e comercialização. A venda de terras para as indústrias, a destruição dos bananais pela poluição e as desapropriações realizadas pelo Estado contribuíram para agravar ainda mais a situação dos sitiantes.

Essas foram resumidamente, as condições favoráveis para a reprodução do capital num primeiro momento.

A autora supracitada destaca o papel do Estado, mas reconhece a acumulação do capital como preponderante nesse processo desenvolvimentista. A história da indústria da construção pesada no Brasil se fez primeiramente com o capital estrangeiro, açambarcado pelo Estado entre os anos 1930 e 1940 e mais tarde, a partir de 1955, com a desnacionalização e reingresso das empresas estrangeiras. Segundo Damiani (1984), o processo de centralização do capital traduz assim uma dinâmica da acumulação que comporta forças contraditórias, onde muitas vezes, as indústrias de menor composição orgânica servem de respaldo para as maiores não sendo desta forma eliminadas - e sofrem também, por conta desse processo, algumas transformações.

Tanto a construção da Light quanto a construção da Via Anchieta ${ }^{67}$ ajudou na formação do contingente de trabalhadores que, em sua maioria, morava nas favelas da cidade, algumas próximas às fábricas, como a Vila Parisi e o Jardim São Marcos. Essas favelas chegaram a ser tratadas por Goldenstein (1965) como casas precárias, insalubres, feias e sem infra-estrutura básica.

Para Damiani (1984), a força de trabalho foi um fator preponderante na concentração industrial em Cubatão, sendo que a mesma, articulada com a dinâmica do capital, teria produzido as favelas e os favelados da cidade, através da exploração do trabalho. A permanência desses trabalhadores na cidade, na maioria das vezes, só foi possível nas favelas e em condições de marcada pobreza. O preço dos aluguéis era altíssimo e, com a crescente valorização da terra, que surgia

67 A grande maioria dos operários que trabalharam no D.E.R. (Departamento de Estradas de Rodagem) durante a construção da Via Anchieta utilizavam os acampamentos do próprio DER como moradia. Mais tarde esses acampamentos se metamorfosearam em núcleos de favelas. (DAMIANI, 1984, p. 23). 
concomitantemente ao desenvolvimento do centro produtivo, muitos trabalhadores procuravam uma alternativa de moradia em cidades vizinhas.

Desde o começo da implantação do pólo-industrial, tanto as famílias enriquecidas com a produção de bananas, quanto os funcionários qualificados e melhor remunerados optavam por residir em outros municípios, principalmente em Santos. Segundo Peralta (1979, p. 149), "a vida social existente anteriormente foi sufocada ou isolou-se em grupos fechados." Nesse contexto, houve a formação das favelas e a ocupação de áreas de difícil acesso, explica Damiani, ao comparar o início dos anos 1950, quando o morador conseguia ser proprietário da terra ou de sua casa, com o trabalhador da segunda fase de industrialização.

Dos 14.672 funcionários permanentes de 19 empresas de destaque no município, apenas 3.711 (25,25\% do total) funcionários viviam na cidade em 1974. Conforme Boletim da Prefeitura (PERALTA, 1979), em apenas seis anos, esse número caiu para 18\%, segundo Ferreira (COUTO, 2003). Um memorialista, nosso entrevistado, comenta sobre essa opção de moradia:

Então muitos daqueles meus amigos falaram pra mim, há 40 anos atrás: "É Ayres... Você não quis ir pra Refinaria, eu estou ganhando bem" - mostrava aquele meio tijolo de dinheiro embrulhado naquela borrachinha... - (e diziam) "agora você vai ficar na poluição mesmo, então eu vou levar minha mulher pra descansar um pouco, de táxi, em Santos, no Gonzaga, pra tomar sorvete!" (...) A turma da Refinaria faz tudo para não pisar no território cubatense. Vem aqui pra trabalhar, buscar o dinheiro deles. Pegam eles em casa, de porta em porta, o ônibus deixa eles dentro da refinaria; eles tomam sua posições... Quer dizer, eles nem sabem como é Cubatão, chegam na hora certa, o ônibus já tá esperando eles. Eles só sabem que existe Cubatão por que eles passam no meio. Quando a Refinaria e as outras que vão também acompanhando, crescendo e também vão ganhando bem, vão fazendo o mesmo, então existe um certo preconceito, os que estão aqui são chamados peões, e os outros que ganham um salário em condições de comprar uma casa, enquanto a gente aqui vai morar nas invasões. (Entrevistado pela autora, agosto/2005) 
As empresas investiram em transporte para seus funcionários. Os ônibus fretados atravessam a cidade levando os funcionários da fábrica para as cidades vizinhas. Mesmo na cidade, circulam alguns poucos recolhendo funcionários. Cubatão, segundo Couto (2003), foi transformada em meados dos anos 70 em cidade mercado-de-trabalho de pessoas que moravam em cidades vizinhas.

A grande massa de trabalhadores que permaneceu em Cubatão contribuiu para a explosão das favelas. A Vila Esperança, por exemplo, é uma extensão da Vila Natal, que avançou sobre o mangue em direção ao município de São Vicente. Nesse mesmo local percebemos uma outra expansão em direção aos bolsões 7 e 8, uma subdivisão da Vila Esperança, que os moradores denominam Sítio Novo. Nas proximidades, encontramos o Vale Verde, um loteamento com casas bem construídas que, no início de sua estruturação, surgiu como um condomínio.

Em Cubatão, a dinâmica sócio-espacial denota uma produção do espaço voltada às necessidades das indústrias, como uma interferência no processo de valorização da terra no local, tendo como agente dessa produção a figura do trabalhador (peão ${ }^{68}$ ) explorado pelas empreiteiras, empresas responsáveis pelas obras de construção e ampliação das indústrias, que pagavam baixos salários, abrigando-os primeiramente em alojamentos - e sua condição de favelado. Desta forma, a riqueza material oriunda das indústrias de Cubatão acaba também gerando a pobreza, através da mediação do processo produtivo, conforme expõe Damiani (1984).

O plano da cidade resulta de sucessivas anexações de loteamentos, sem que se tenha processado nenhuma integração entre eles, conforme Peralta (1979) e

${ }^{68}$ Peão é como são conhecidos em Cubatão os trabalhadores sem qualificação. E Damiani (1984, p. 112) parafraseando José de Souza Martins a respeito do bóia fria, escreve: "os peões são trabalhadores permanentes permanentemente temporários". Com respaldo, muitas vezes, de determinações jurídico-políticas. Um entrevistado nosso dá a interpretação de peão que ele conheceu ao chegar em Cubatão, que reconhece e descreve ao cunhado recém-chegado que quer saber o significado dessa denominação:

(...) Ele perguntou: o que que quer dizer "peão", que tipo de gente? Falei, não, peão é o mesmo tipo de pessoas comum. É que a turma não conhece, né, aí chama peão que é na base é geral, né, mas é então ficava naquela, rapaiz o que que quer dizer peão, porque lá pra nóis lá peão lá é quem monta em burro selvagem, burro bravo, né, então o pessoal pensou que os peão daqui era outro tipo de gente, né, (risos) igualmente o índio porque a pessoa que não conhecia pensou que o índio era um outro tipo de pessoas, né, e é a mesma pessoa, né, só que era um modo de tratar a pessoas às vezes mais agressiva, né, mais grosso pra responder as pergunta. (Entrevistado pela autora, janeiro/2004) 
Goldenstein (1965). Desta forma, a estrutura urbana caracteriza-se pela fragmentação. $O$ isolamento de alguns bairros, como é o caso das antigas Vilas Operárias, e a atração exercida pela cidade de Santos ${ }^{69}$, além da crescente concentração das indústrias teriam acentuado o processo de fragmentação, na visão de Goldenstein (1970) e Damiani (1984). Com exceção dos bairros que próximos ao centro da cidade, o restante aparece de forma fragmentada.

Durante o período da ditadura militar, iniciada com o Golpe de Estado no dia 31 de março de 1964, Cubatão foi uma das áreas declaradas como "área de Segurança Nacional". Desta forma, seus prefeitos passaram a ser nomeados pelo presidente da República e muitas das reivindicações dos habitantes locais passaram despercebidas. No entanto, houve gastos altíssimos com obras "faraônicas", relata Couto (2003), destacando a própria construção da Câmara Municipal, que de tão suntuosa para a época e para a cidade, surpreendia até os visitantes mais ilustres ao passo que a população vivia na miséria.

A apropriação e monopolização de extensos espaços pelas indústrias não se deu de uma só vez, conforme observamos nos trabalhos consultados. Na década de 70, indústrias químicas adquiriram fazendas e sítios. Atualmente ainda há tentativas de apropriação de pequenas terras ao redor das fábricas, que ocorre simultaneamente a um movimento de desfavelização. Segundo Damiani (1984) essa desfavelização pode ser chamada de "tentativa de extinção de espaços periféricos pobres" que, nos meados dos anos 70 e anos 80, chegou a se confundir com a "tentativa de açambarcamento pelas indústrias dos espaços necessários à expansão industrial", remetendo a um "processo de desfavelização tático".

Um exemplo dado pela autora foi a transformação da Vila Parisi em área de Reserva Ambiental e Ecológica, em 1985, promovida pelo então prefeito de Cubatão, contrariando a determinação do decreto estadual $n \div$. 23.040/84. Foram removidos aproximadamente 20 mil moradores. A ação precipitada foi justificada pela situação de poluição alarmante na cidade, que desde 1980 vinha sendo denunciada pelos relatórios da Cetesb (Companhia de Tecnologia em Saneamento Ambiental) e

\footnotetext{
${ }^{69}$ A atração da cidade de Santos também é mencionada no trabalho de Peralta (1979).
} 
divulgada pelos meios de comunicação, tornando a cidade conhecida como "Vale da Morte".

Couto (2003), descreve o início desse processo de desfavelização em dezembro de 1975, pelo então prefeito nomeado Carlos Frederico Soares Campos. O prefeito pretendia acabar com as favelas Vila Parisi, Vila São José, Cotas (95, 100, 200, 400 e 500), Lixão, Pista descendente da Via Anchieta, Sítio Cotia-Pará e Ilha Caraguatá, porém sem sucesso. Uma nova tentativa foi feita em 1980, com o Plano de Erradicação das Favelas, mas também falhou. Diante da acusação de desvio de dinheiro público, por parte de alguns políticos, o então prefeito Carlos Frederico Soares Campos foi exonerado do cargo, sendo nomeado como novo prefeito José Osvaldo Passareli, em 18 de fevereiro de 1982 - época em que o problema ambiental ganhava grande destaque, exigindo algumas medidas enérgicas e, ao mesmo tempo, abrindo novas possibilidades de um remanejamento territorial. Houve nova tentativa de conter as expansões das favelas em 1986, mas sem êxito.

A desapropriação da área da Vila Parisi, entre outras, por exemplo, a área para construção do aterro sanitário e para construção do Serviço Nacional de Aprendizagem Industrial (SENAI), tornaram-se precatórios judiciais durante a década de 1990 (COUTO, 2003). Um entrevistado relatou-nos que esses precatórios são altíssimos, e se originaram das desapropriações para implantação de projetos habitacionais, no intuito de acabar com os déficits de moradia no município.

(...) Parece que não foi feito um levantamento aprofundado para saber a quem pertenciam essas áreas. Sabe-se, hoje, que muitas delas pertenciam ao patrimônio da União, sendo assim, o município não poderia ter desapropriado área da União. Portanto, o entrevistado reconhece: Houve alguns equívocos, alguns erros... Mas já está julgado e tramitado, ficando difícil rever esses valores que seriam exorbitantes hoje. Parece que agora existe uma lei ${ }^{70}$ que divide essas parcelas de pagamento precatório em dez parcelas, em praticamente dez anos... E o município é penalizado; não solucionou o déficit e ainda criou um problema financeiro para a prefeitura em

\footnotetext{
70 Talvez o entrevistado quisesse se referir à Lei de responsabilidade Fiscal.
} 
conseqüência dessas desapropriações. (Entrevistado pela autora, julho/2006).

Em 1996, foi assinado um acordo chamado de "Pacto de Cubatão", com o intuito de conter as invasões no município, porém sem efetivação.

No ano de 2000, foram registrados 23 núcleos considerados favelas ou áreas de risco (Mapa 2), conforme relata Brandão citado por Couto (2003). Esse mesmo trabalho menciona uma nova medida da prefeitura, de fevereiro de 2002, que consiste numa estratégia de "invasão zero", derrubando todo barraco novo construído em área irregular. Para tal ação, a prefeitura conta com o apoio da Polícia Militar, Ambiental Florestal e com o Ministério Público. Atualmente, a prefeitura calcula que existem 64 mil pessoas vivendo em favelas, ou seja, 59\% da população.

A preocupação maior é com a desfavelização das áreas ocupadas e não a urbanização dessas áreas. Atualmente, podemos citar, por exemplo, a remoção da ocupação chamada de Jardim São Marcos, localizada em área industrial valorizada, e da Vila dos Pescadores. Essa Vila, localizada em área de mangue, fica às margens da Rodovia Anchieta, quase já na divisa com a cidade de Santos e ao lado da Alemoa ${ }^{71}$, em Santos.

Segundo informações oficiais da Prefeitura, a Vila dos Pescadores originou-se na década de 1960 com um grupo de pescadores que se instalou no local com o objetivo de explorar o Rio Casqueiro. No entanto, obtivemos um relato sobre a ocupação feita por funcionários da rede ferroviária São Paulo Railway, que foram instalados nesse local, em 6 a 7 imóveis, com o intuito de fazerem a manutenção dos trilhos da ferrovia. Hoje, na Vila dos Pescadores, vivem quase 30 mil pessoas em 5 mil moradias, ocupando uma gleba de 2 milhões e 750 mil metros quadrados. Segundo a Prefeitura do município, será feita a reurbanização da Vila, e, concomitantemente, a recuperação ambiental do mangue, a partir do Projeto GuaráVermelho $^{72}$ de Gestão Ambiental e Renovação Urbana de Cubatão. O projeto Guará-Vermelho teve aprovação do Governo Federal em março de 2005.

\footnotetext{
71 Área pertencente ao município de Santos, que abriga um grande depósito de containeres e uma pequena vila.

72 Guará-Vermelho é uma ave ciconiiforme pertencente à família dos tresquiornitídeos, cujo nome científico é Eudocimus ruber, apresentando aproximadamente $58 \mathrm{~cm}$ de comprimento, com colorido escarlate. (FERREIRA \& PASSERANI, 2005).
} 
MAPA 2 - LOCALIZAÇÃO DOS NÚCLEOS DE FAVELAS E ÁREAS DE INVASÃO

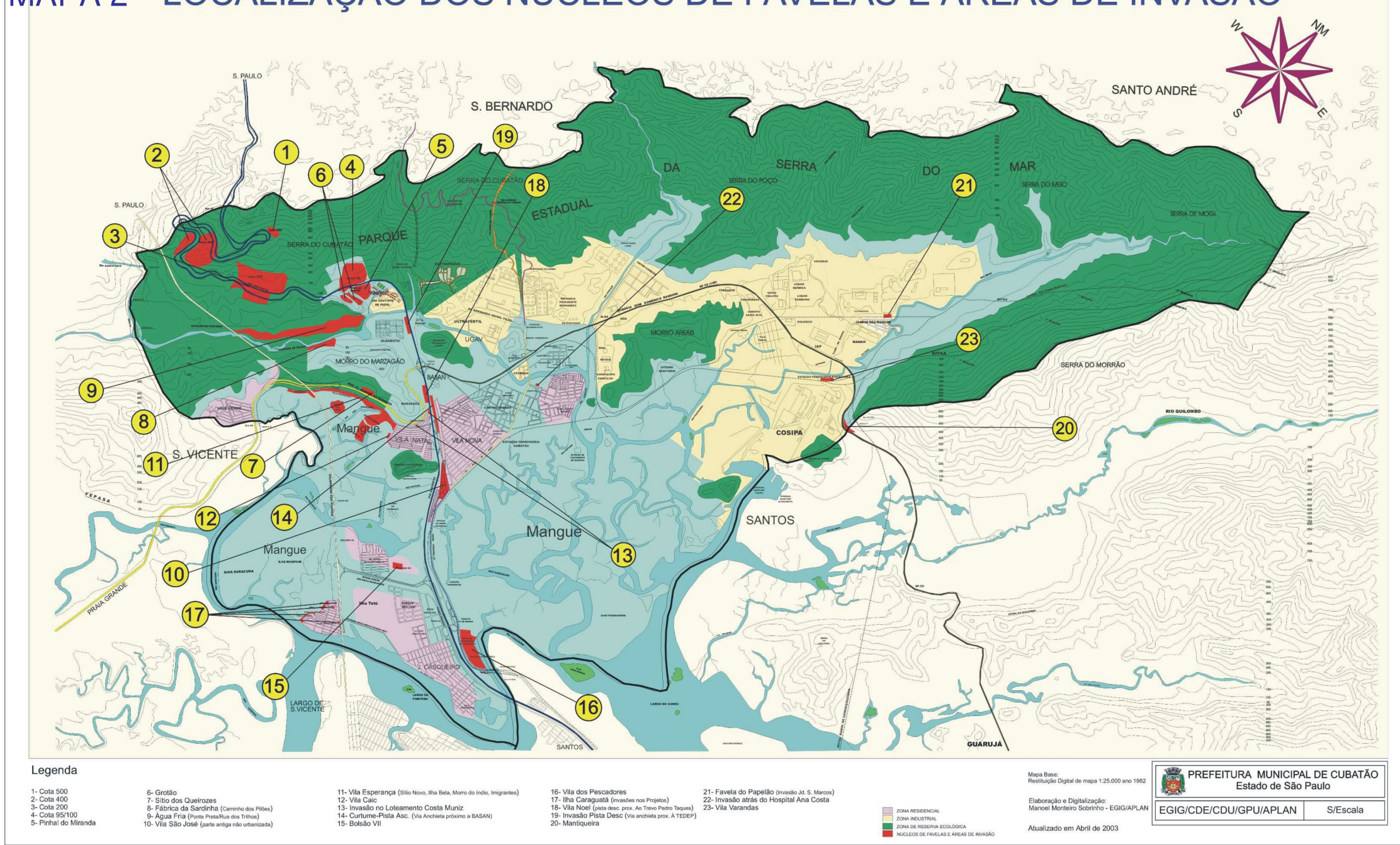


A reurbanização é descrita pela prefeitura como a construção de 1.776 unidades habitacionais de alvenaria para os atuais moradores, mas conta com a demolição de 1.176 barracos. O projeto, que faz parte do programa "invasão zero" no município, é da Prefeitura Municipal de Cubatão em parceria como o Banco Mundial, que destinou 42 milhões de dólares para a contenção de novas ocupações irregulares e construção de residências. Apenas um terço da área será ocupada na reurbanização da vila, o restante será reservado para fins de preservação ambiental. A compra do terreno custará um milhão e 405 mil reais $^{73}$ aos cofres públicos. A prefeitura investirá 16 milhões de dólares no projeto. $O$ intuito seria a preservação das áreas de mangue e do pássaro guará-vermelho, típico dessa região. O primeiro montante de 785 mil dólares já foi doado pelo Governo Japonês para a contratação das empresas de elaboração do Programa (JORNAL FOLHA..., 2006).

O processo de ocupação das áreas de mangue pela população é recorrente - o que sempre causa uma preocupação por parte da Prefeitura em entrar com uma ação de desocupação, desfavelização e preservação da área; muitas vezes, essas ações recebem o apoio de outros setores sociais, seja o Estado, o Governo Federal ou, até mesmo, o capital estrangeiro. Outro ponto a ser considerado é a falta de uma legislação adequada que defina o uso de algumas áreas da cidade conforme o zoneamento. O resultado é a apropriação de certa quantidade de terra para a instalação de grandes empreendimentos capitalistas sob 0 discurso de desenvolvimento da região e geração de empregos para a grande massa de trabalhadores sub-empregados e desempregados da cidade, como é o caso de dois grandes projetos em vias de realização: a construção de um Central de Abastecimento (CEASA) Regional e de um Terminal de Cargas Rodoviárias.

O CEASA será construído em uma região privilegiada, uma área de preservação ambiental de quase 3 milhões de metros quadrados cadastrada no Serviço de Patrimônio da União, nas proximidades da llha Nhapium, ao longo da Rodovia dos Imigrantes, na interligação Anchieta-Imigrantes, próximo à llha Caraguatá. O projeto será executado pela empresa Brasterra e já sofreu várias modificações. Em sua versão recente, ele conta com uma área destinada a comércio e serviços - onde se instalarão empresas de pequeno porte. Nesse projeto também figura um acordo com

\footnotetext{
${ }^{73}$ Sendo 118 mil de entrada e o restante dividido em 11 parcelas mensais.
} 
a Secretaria do Meio Ambiente, no qual a empresa se compromete a construir um Conjunto Habitacional para as famílias que atualmente moram em áreas consideradas de invasão e, principalmente, em áreas de risco. Porém as obras ainda não foram iniciadas devido aos trâmites ambientais e à regularização fundiária ${ }^{74}$, o que tem levado o projeto a sofrer repetidas alterações.

Com relação ao Terminal Intermodal de Cargas Rodoviárias (TIC-R), um Centro de Pesquisas Ambientais e instalações de um Pólo Industrial Metal-mecânico, a prefeitura assinou em junho de 2006 o termo de transferência e aditamento de contrato de concessão de uso da área por 30 anos. O Ecopátio se localizará no km 262 da Rodovia Cônego Domenico Rangoni, numa área de 442.679,36 m². As empresas envolvidas nessa construção são: a concessionária Ecopátio Logística Ltda e garantidora Primav EcoRodovias S/A, Makrom Comércio e Participações Ltda. (JORNAL COSTA..., 2006).

Percebemos assim a complexidade da questão urbana em Cubatão. A urbanização da cidade aparece, segundo Damiani (1984), diluída em outras cidades da Baixada Santista e também na metrópole paulista. A isso se soma a contenção da expansão urbana, uma economia urbana atrofiada em relação ao comércio e aos serviços, a valorização da terra favorecendo as indústrias, altos investimentos em correções de áreas de mangues e morros, poluição, subordinação aos centros urbanos próximos e uma grande segregação espacial. O que a história da cidade nos mostra é que as necessidades da população residente em Cubatão sempre estiveram fora do foco das políticas públicas ${ }^{75}$ e isso parece se perpetuar. Segundo Peralta (1979), a urbanização ocorrida em Cubatão foi comprometida e deterioradora das condições de vida da população, sem incorporar a população à cidade.

Hoje pode até existir um esforço em atender algumas necessidades da população, como observamos com relação à construção de moradias populares, mas tais empreendimentos ainda não contemplam as necessidades efetivas dos habitantes, tampouco se projetam em direção ao habitar. O Estado articula os espaços conforme os interesses do capital e a população vive o conflito instaurado no seu

\footnotetext{
${ }^{74}$ A empresa está tentando regularizar a situação junto ao SPU.

${ }^{75}$ Conforme concluiu Peralta (1979) e Damiani (1984).
} 
cotidiano, um conflito acentuado pela pobreza, pelo desemprego, pela fragmentação, segregação e tentativa de apropriação da cidade.

\subsection{Migração e Proletarização}

Veja bem, se tivesse lugar para essas pessoas criarem seus filhos, essas pessoas não tinham necessidade de vir pra outros lugares e enfrentar um alto-forno. Quem é que, meu Deus do céu, quem é que em sã consciência vai deixar de ouvir o mugido de uma vaca para enfrentar o calor do alto-forno? Ninguém em sã consciência! Está entendendo? Infelizmente isso é um fato. Agora, que o progresso tem que acontecer, isso é um fato. Agora, pode acontecer o progresso e não a devastação do campo! Tem como, é só querer, é só querer... (Entrevistado pela autora, maio/2006)

Este relato, obtido durante nossa pesquisa, é bastante significativo, na medida em que expõe a relação do homem do campo frente aos processos do capital. Póvoa Neto (1997) destaca o constrangimento sofrido pelo trabalhador diante da necessidade de se deslocar como estratégia de sobrevivência, e Gaudemar (1977) enfatiza que a causa da migração é justamente a coerção exercida pelo sistema produtor de mercadorias, levando o homem a viver um processo de exclusão ${ }^{76}$ ampla, colocando-se em disponibilidade "para a utilização compulsória de sua força de trabalho nos moldes capitalistas" (PÓVOA-NETO, 1997, p. 19). Portanto, a mobilidade do trabalho ${ }^{77}$ está inserida na própria estrutura de desenvolvimento do capital $^{78}$.

Em 1970, a ONU apresentou uma definição formal de migração. Segundo a Organização, a migração é o deslocamento de uma área definidora do fenômeno para outra, ou um deslocamento a uma distância mínima especificada, que se realiza durante um determinado intervalo de tempo, e implica uma mudança de

\footnotetext{
${ }^{76}$ Esse processo é iniciado já em sua terra natal, bem como o desenraizamento. Por exemplo, a impossibilidade de acesso à terra. Sobre isso ler PENNA (1994).

77 Gaudemar (1977) define a mobilidade da força de trabalho como sendo uma característica do trabalhador submetido ao capital (ao modo de produção capitalista).

${ }^{78}$ A mobilidade do capital já aparece em estudos de Karl Marx. Encontramos também essa discussão no trabalho de Damiani (1984).
} 
residência. (SALIM, 1992 apud PÓVOA-NETO, 1997). Tal definição apresenta inúmeras dificuldades para a caracterização do fenômeno migratório, dado o seu conjunto de movimentos e combinações variáveis.

Para tanto, poderíamos esclarecer algumas principais correntes teóricas sobre os estudos da migração. A maioria dos trabalhos relacionados ao tema indica a desigualdade econômica como causa motora principal, porém tentaremos destacar a relação entre mobilidade, trabalho e capital. Em geral, os estudos sobre a questão migratória tratam o fenômeno através dos enfoques neoclássico, histórico-estrutural e do conceito de mobilidade do trabalho.

As teorias neoclássicas destacam a liberdade de escolha individual da pessoa que migra, onde o sujeito aparece como unidade de análise. A migração seria então fruto de uma decisão pessoal. O migrante é visto como o portador do fator trabalho, que busca em outros espaços, um máximo retorno para seus investimentos. Assim, os desequilíbrios sócio-econômicos seriam corrigidos com a migração, numa concepção dualista da economia. Os indivíduos, apresentando impulsos supostamente "eternos", sempre buscariam melhores condições através da remuneração do trabalho, submersos na dinâmica do mercado capitalista. Segundo Póvoa-Neto (1997), essa perspectiva desconsidera a dimensão histórica das migrações.

A segunda concepção teórica é a histórico-estrutural, enraizada na tradição do materialismo histórico, que considera contextos históricos e geográficos específicos, a partir da análise de grupos e classes sociais sob a influência da força de estruturas sociais na decisão de migrar, explicando a migração como um fenômeno social. A ênfase desse estudo recai sobre os aspectos estruturais da expulsão dos indivíduos de suas áreas de origem, e sobre a adaptação dos mesmos nas áreas para as quais se dirigiram, utilizando-se para tanto a escala do sujeito. Embora o indivíduo seja considerado como fonte de informação para a análise do fenômeno, ele não conseguiria explicar os processos vivenciados. Segundo Póvoa-Neto (1997, p. 18), esses estudos apresentam "problemas quanto à conciliação entre os níveis macro e micro". Na visão do autor, há uma preocupação dos estudiosos histórico- 
estruturalistas no que se refere à saída ${ }^{79}$ dos trabalhadores inseridos em estruturas sociais tradicionais e sua trajetória rumo ao mercado de trabalho "propriamente" capitalista, além de apresentar aos geógrafos a questão de compatibilizar as condições sociais com a análise de motivação individual.

Sob a ótica da análise crítica ${ }^{80}$ sobre a migração, a qual se refere Salim (1992), a estrutura social aparece como fator que impele o deslocamento da população, ou contingente da força de trabalho; ou seja, a característica da força de trabalho, a mobilidade ${ }^{81}$, está sujeita ao capital, à produtividade e à expansão física do mesmo - apresentando-se como conseqüência e condição física do desenvolvimento das forças produtivas. Isso porque o capital ${ }^{82}$ usa como estratégia de mobilização do trabalho, a mobilidade forçada. Segundo Gaudemar (1977, p.190-191): "o dinheiro vem reforçar esta tendência e assim estimular a mobilidade da força de trabalho. Pouco importa o emprego, desde que o salário recebido em troca seja satisfatório." A mobilidade adquirida pelo trabalhador parte das contrariedades que the foram expostas pela própria procura de emprego a qual ele se submete.

Logo, a decisão de migrar é interpretada como uma mobilidade forçada pela necessidade de valorização do capital, e não como um ato de livre escolha do indivíduo. Assim, os grupos sociais e suas trajetórias tornam-se categorias de análise, ao invés de se considerar apenas o indivíduo e os fluxos migratórios.

Sob esse ponto de vista, o migrante passa a ser definido como o indivíduo que segue "os movimentos do capital sob a condição de força de trabalho assalariada ou potencialmente assalariada". (BECKER, 1998, p. 342)

A expulsão do homem do campo e o não aumento da oferta de empregos na cidade traduziriam, então, o movimento da população seguindo os interesses do capital, que apresenta como tendência geral açambarcar todas as formas anteriores de

\footnotetext{
79 Expulsão da população rural em decorrência dos processos de modernização da agricultura e modificações na estrutura agrária. Sobre isso, o autor sugere a leitura da obra de Paul Singer: "Economia Política da Urbanização". 2. Ed. São Paulo: Brasiliense, 1975.

${ }^{80}$ Que trata da mobilidade da força de trabalho.

81 "A mobilidade é a capacidade que permite à força de trabalho adaptar-se às variações da jornada de trabalho, à permutação dos postos de trabalho, aos efeitos de uma divisão do trabalho cada vez maior". (GAUDEMAR, 1977, p. 194).

${ }^{82}$ O surgimento da mercadoria é anterior ao capitalismo. A transformação do trabalho em mercadoria marca o surgimento do capitalismo. (GAUDEMAR, 1977, p. 194).
} 
produção, dominando as esferas concorrentes, e incorporando-as no seu processo de reprodução. As formas de mobilidade do trabalho aparecem, portanto, como fenômenos de submissão e não de liberdade. No que se refere à liberdade, Gaudemar (1977, p. 190) explica que:

No seu aspecto positivo, a 'liberdade' conduz à possibilidade do trabalhador escolher o seu trabalho e o local onde exercê-lo; no seu aspecto negativo, ela conduz às exigências do capital e ao seu poder de despedir em qualquer altura um trabalhador, ou de transformar o seu trabalho assim como as condições em que ele o exerce. Em ambos os casos a força de trabalho deve ser móvel, isto é, capaz de manter os locais preparados pelo capital, quer tenham sido escolhidos quer impostos; móvel quer dizer apta para as deslocações e modificações do seu emprego, no limite, tão indiferente ao conteúdo do seu emprego como o capital o é de onde investe, desde que o lucro extraído seja satisfatório.

O trecho apresentado por Gaudemar pode ajudar na reflexão sobre o dilema, muitas vezes presente na análise geográfica a partir da perspectiva histórico-estrutural, e também no entendimento da questão migratória.

Consideremos a observação de Simonetti (1999 apud MARQUES, 2000), ao descrever as modificações das relações de produção no campo a partir de 1960 . Para Marques (2000), tais relações não só "geraram a exploração pura e simples dos camponeses", como também os transformou em uma população sobrante, de desempregados e sub-empregados. Isso acontece porque sua grande maioria sofreu o processo de expropriação, sujeitando-se ao capital, uma vez que a expansão do capitalismo destrói as bases de produção da economia tradicional. $O$ que se projeta como alternativa é a mudança de vida através do deslocamento, na tentativa de restabelecer o antigo equilíbrio existente entre as necessidades socialmente definidas e a remuneração do trabalho - que já aparece como uma nova necessidade para o homem do campo (DURHAN, 1978).

Os desajustes causados pela expansão capitalista tiveram seus efeitos exacerbados sobre o campo e seus moradores. Desta forma, a permanência no campo passou a exigir grandes esforços, ao passo que as possibilidades dispostas pelo processo de industrialização tornaram-se grandes atrativos para a população já expropriada pelo 
capital. Assim, este contingente populacional seria absorvido pelas formas de exploração extensivas (DAMIANI, 1999a) do capital, em uma de suas facetas: a proletarização - amparada pela política econômica do Estado, que cria e garante as condições para essa sujeição (MARTINS, 1995).

A grande maioria de nossos entrevistados é de origem camponesa; alguns tiveram uma experiência de vida permeada por atividades rurais e extrativistas (retirada de areia dos rios, coleta de folhas do mangue, pesca) realizadas por eles mesmos ou membros de sua família. De qualquer forma, eles apresentavam condições precárias de vida: trabalhando para fazendeiros, em terras de usinas de açúcar ou morando em propriedades de parentes. A busca de melhores condições de vida aparece em seus relatos como o fator principal de migração para a cidade, principalmente, a partir da década de 50.

Morava todo mundo junto. Foram tudo criado todinho naquele local. Aí os irmãos e irmãs mais velha, né, elas foram casando e foram embora e a gente foi ficando. Aí depois ficou difícil pra gente. Aí a gente pegou e começou a sair pra cá também, né. (Entrevistado pela autora, janeiro/2004)

Se por um lado, o homem do campo se realiza com o trabalho camponês, por outro, ele se sente inseguro quanto às condições de sobrevivência, principalmente no que se refere à imprevisibilidade da colheita ${ }^{83}$, conforme o relato:

É... na roça é mais puxado porque a gente ali planta para aventurar, né? Lá no Norte a gente fazia a plantação, depois vinha o sol e às vezes faltava chuva para molhar... E assim por diante, então nós veio para cá para arrumar, para melhorar mais, né? (Entrevistado pela autora, agosto/2005)

As dificuldades enfrentadas no campo levam o trabalhador rural a repensar suas condições de existência. O Brasil, a partir da política nacionalista adotada por

${ }^{83} \mathrm{O}$ modo de vida tradicional possui uma economia moral, uma lógica específica que busca o ajustamento dessas descompensações. No entanto, as dificuldades enfrentadas pelo processo de reprodução do capital causam um desajuste maior, expropriando e expulsando o homem do campo. Porém isso também não impede sua reprodução (no próprio espaço do campo) enquanto classe social. 
Getúlio Vargas (1930-1945), deu apoio às chamadas indústrias de base ${ }^{84}$, o Estado passou a ser um verdadeiro agente da industrialização.

Com as importações prejudicadas pela Segunda Guerra Mundial, a indústria nacional recebeu ainda mais estímulos. Grandes investimentos foram feitos para sustentar a reprodução do capital. Estradas foram construídas e ampliadas, e a navegação, assim como a indústria do aço e do petróleo, recebeu um grande incentivo. Em 1938, foi criado o Conselho Nacional do Petróleo (CNP), mais tarde, em 1940, o governo criou a Companhia Siderúrgica Nacional (CSN), em Volta Redonda - RJ, e a Companhia Vale do Rio Doce, com o objetivo de explorar as jazidas de ferro em Minas Gerais. No intuito de financiar o programa de crescimento econômico e a modernização do país, em 1952, o governo criou o Banco Nacional de Desenvolvimento Econômico Social (BNDES). E com a instalação da refinaria de Petróleo Presidente Bernardes em Cubatão, outras indústrias também acabaram se instalando no local, transformando-o num grande pólo industrial.

Até os anos 80 houve um grande crescimento em todos os setores industriais. Tanto a indústria nacional quanto a internacional necessitava de mão-de-obra barata, matéria-prima e mercado para o escoamento de produtos. Portanto, a migração para Cubatão, assim como para outros locais onde o desenvolvimento industrial se estabelecia, colocava o migrante dentro da lógica de reprodução do capital, criando condições para o desenvolvimento das forças produtivas.

A cidade passou a ser interpretada como um local para se "ganhar a vida", o lugar das oportunidades e do possível. Nesse sentido, a proletarização despontou como um caminho para a obtenção de melhorias materiais, como possibilidade de acesso a emprego e a bens - o que não deixa de ser uma estratégia de sobrevivência frente ao constrangimento causado pelo capital.

A mão-de-obra no campo aparece desvalorizada e sem perspectiva de mudança, conforme o relato de um entrevistado dizendo, indignado, que em seu local de origem, nos dias de hoje, um trabalhador na roça recebe oito reais por dia trabalhado: roçando pasto, capinando roça, das sete da manhã às cinco horas da

84 "Responsáveis pela confecção de produtos usados como matéria-prima por outras fábricas". (PINTO, 2005, p. 79). 
tarde, na enxada o dia todinho... Outro entrevistado revela que o dia trabalhado no interior da Bahia, em Feira de Santana, vale três reais e cinqüenta centavos. Assim, a permanência na roça torna-se difícil. Muitas vezes o assalariamento no campo surge como alternativa que viabiliza a permanência no próprio campo, garantindo a reprodução dessa classe social. Muitos entrevistados mencionaram parentes e amigos que permanecem ainda no campo sob a condição do assalariamento.

Tem muitos que ainda continua lá, né Silvério, morando ainda na terra de fazendeiro, trabalhando pra fazendeiro. (Entrevistada pela autora, janeiro/2004)

É, da mesma época da'gente, né, e continuam trabalhando pra fazendeiro e num conseguiu comprar nada, né. A gente, graças a Deus, ainda tem uma casinha aqui, né, (risos) não é muita coisa, mas... (Entrevistada pela autora, janeiro/2004)

Eunice Durhan (1978) explica que as novas necessidades criadas pela industrialização só podem ser satisfeitas através do ato da compra, já que, diante das pressões da economia de mercado, a produção do camponês se revela insuficiente. Para aumentar a renda, o trabalhador rural precisaria intensificar seu trabalho e/ou adquirir mais terras (nos dias de hoje poderíamos falar em mudar a qualidade de seu trabalho e investir em tecnologia). Frente às limitações, a migração passa a ser considerada, já que se apresenta no universo desse sujeito social como reflexo do processo de industrialização, adquirindo um caráter familial ${ }^{85}$.

A pobreza e a expropriação são contrapostas ao sonho de conseguir uma terra própria, uma casa melhor, o resgate de sua independência, liberdade, autonomia e dignidade. $\mathrm{O}$ trabalho regular, por sua vez, aparece ao camponês como mais bem remunerado. Nesse pensamento se destaca justamente a questão do salário recebido ser satisfatório, independente do emprego. Sob essa perspectiva, a força de trabalho já adquiriu o caráter da mobilidade, conforme a definição de Gaudemar (1977). O dinheiro passa a ser algo desejado, um meio para se conseguir o que é apresentado pela sociedade de consumo. Trata-se de um verdadeiro processo de

${ }^{85}$ O caráter familial é apresentado no trabalho de Durhan como fundamental no processo migratório. É definido como a rede familiar que sustenta e viabiliza a migração; no caso dos camponeses a família é compreendida como ordem moral, portanto, de grande expressão para quem migra. 
sedução, artifício do capital. Segundo um entrevistado: "Todo mundo vinha pra São Paulo para arrumar um meio de vida". Alguns chegaram a mencionar que o campo é bom, mas lá infelizmente "não corre dinheiro", a cidade é onde "corre dinheiro". Como bem coloca Gaudemar, a possibilidade de acesso ao dinheiro estimula a mobilidade da força de trabalho.

O fascínio exercido pela cidade trazia uma esperança de mudança de situação, de restabelecimento da fartura, da abundância que já há tempos não se via por aqueles cantos. Ao mesmo tempo se desejava "o novo". Na suposta liberdade de escolher o seu destino, a força de trabalho declara sua mobilidade. Muitos dos que migraram para Cubatão foram sozinhos, para conhecer o novo, o moderno ${ }^{86}$, e depois, retornavam para buscar namoradas ou noivas, casavam-se e se estabeleciam em Cubatão. Outros vieram atrás de algum parente, ou mesmo por intermédio do mesmo. Alguns entrevistados relataram que a princípio desejavam trabalhar na cidade para levantar uma quantia em dinheiro e depois retornar, mas "nunca dava para voltar e foram ficando".

(...) depois a gente pensou de pegar um dinheiro a mais... era a gente ter alguma coisa pra comprar alguma coisa pra'gente...criar animal, lá pega muito animal de cela, né, Criar umas duas vaquinha, ter as coisa da'gente, ter pelo menos um torrão, um terçozinho, né, pra morar, pra evitar de tá morando na terra de fazendeiro, né. A gente via lá muitos que morava na terra dos outros... era muito cobrada, né. (Entrevistado pela autora, janeiro/2004)

O impedimento da volta quase sempre se apresenta como insuficiência de dinheiro. Nesse sentido, o dinheiro reforça a tendência à mobilização dessa força de trabalho.

(...) É por causa que o dinheiro nunca corresponde ao que a gente quer. Se fosse pra mim depender de mim, eu nunca tava aqui, já tinha voltado pra lá já. Já aposentei... Então ficar é ficar ocupando o jovem aqui, né. Mas é, não quero sair daqui. Eu queria deixar aqui e dá aquela de cigano. Eu queria deixar aqui tudo engatilhado aqui e sair assim só com a roupa do corpo, aí eu fico lá dois meses, aí

\footnotetext{
${ }^{86}$ No trabalho de Durhan (1978), o jovem do campo manifesta de alguma forma sua independência arrendando terras por conta própria, casando-se cedo e também se libertando da influência paterna através da migração.
} 
amanhã vou voltava pra Cubatão, né no caso, aí volta pra'qui, não precisava trazer nada. (Entrevistado pela autora, janeiro/2004)

Este relato trata de um outro elemento também encontrado em algumas falas: a necessidade de voltar ao lugar de onde se veio e, ao mesmo tempo, permanecer em Cubatão. $O$ migrante torna-se um prisioneiro da passagem ${ }^{87}$, pertence aos locais de sua passagem. Este entrevistado vive a contradição de querer morar lá e cá. Ele, na verdade, sente que pertence a esses dois mundos. Contudo, esse sujeito social já vive o processo contraditório e a exclusão ampla, evidenciando sua mobilidade forçada que atende a valorização do capital.

Peralta (1979) menciona a grande expectativa do migrante, destacando a fascinação exercida pela cidade grande, pela indústria e o desejo em atingir um nível econômico mais elevado. Mas a realidade encontrada muitas vezes não condiz ao sonho, às expectativas sobre as condições de vida, conforme podemos observar:

Quando eu vim, eu vim na ilusão que nóis ia pra São Paulo, que nóis ia morar em São Paulo. A maioria das pessoas que chegava aqui pensava que era São Paulo. (Entrevistado pela autora, janeiro/2004)

Chegamos em São Paulo, mudamos de condução e eu tô indo pra São Paulo, né, ah vou pra São Paulo! Quando vim vê tava entrando dentro da Vila Parisi (risos), uma vila tão feia, tão feia!.(Entrevistado pela autora, janeiro/2004)

A gente vinha pra São Paulo, mas São Paulo ficava bem pra trais. (Entrevistado pela autora, janeiro/2004)

Embora houvesse uma certa facilidade em conseguir emprego nas décadas de $60 \mathrm{e}$ 70, o desemprego também se fazia presente em Cubatão. Pessoas chegavam a passar um ano sem emprego.

Damiani (1984) usa o termo "escravidão assalariada" ao se referir ao tipo de transformação da mão-de-obra feito pelo capital, ora absorvendo, ora expulsando o trabalhador do mercado de trabalho. Isso evidencia a pobreza vivida por esse sujeito, a partir da "venda fragmentária de sua força de trabalho", caracterizada pela

${ }^{87}$ Sobre isso, ler George Simmel (1963). 
"rotatividade do trabalho e seu caráter nômade". Poderíamos dizer que o conceito de mobilidade forçada de Gaudemar está presente nessa exposição de Damiani.

Nos relatos de nossos entrevistados, a razão principal para a migração aparece como necessidade de ganhar a vida, de melhorar de vida, assim como já havia sido apontado nos estudos de Peralta (1979, p. 224): "Os migrantes se dirigem a Cubatão, na tentativa de melhorar de vida, embora raramente consigam precisar em que consiste essa possibilidade de melhorar".

A limitação em não saber dizer com exatidão o significado dessa idéia também foi constatado e mencionado por Durham (1978). Em seu estudo ela ainda menciona que além de não conseguirem descrever essa situação, seus entrevistados não conseguiam mencionar os elementos negativos da situação anterior. E, a seu ver, a percepção do trabalhador referente a isso é difusa e pouco articulada.

Concordando com Durham acrescentaríamos, com base nos dados coletados, que, no decorrer da sua trajetória de vida, o migrante passa a ter essa noção relativizada, mas ainda não consegue explicá-la diante do processo de fragmentação do seu cotidiano. Muita coisa perde o sentido nesse caminho. É assim que o vivido vai adquirindo uma nova forma; os valores anteriores vão, aos poucos, sendo reinterpretado, mudando, enquanto outros elementos ganham uma importância maior. E, embora possam vivenciar alguma melhora de vida, sua situação em vários aspectos não foi transformada. A aquisição de alguns bens materiais através do dinheiro proveniente do assalariamento não é capaz de responder a todas as expectativas do migrante. E é no processo de proletarização que ele começa a perceber isso.

Os entrevistados não mencionaram o sucesso profissional ou o enriquecimento buscado através do trabalho na cidade, o que transparece nos relatos é a necessidade da sobrevivência com condições dignas. Tais condições incluem, possivelmente, um salário satisfatório, que atenda as necessidades criadas pelo capital. Quando perguntamos a um entrevistado sobre sua mudança e de seu trabalho na nova realidade urbana, ele respondeu que "em São Paulo se a pessoa tiver coragem de trabalhar para progredir, aí a pessoa progride, vai pra frente". Ele declara que não é rico, mas trabalhou, recebe um dinheirinho do INPS, trabalha pra fora vendendo sorvete pra "interar" o dinheiro e tem a horta. "Está bom", diz ele. Há 
o reconhecimento da cidade grande, com suas oportunidades de trabalho, como um local possível à aquisição de capital, ao enriquecimento, (progredir, ir para frente, segundo a lógica capitalista ${ }^{88}$ ), porém o entrevistado se considera realizado, ou ao menos numa situação que ele julga razoável, confortável.

O conforto é algo que sobressai nas entrevistas, significando que as necessidades básicas, alimentação, emprego e moradia, são satisfeitas. A "melhora de vida" aparece em alguns relatos como algo conquistado e consolidado na cidade, ainda que o migrante considere os limites dessa melhora, considerando a situação em que vive. Em outros relatos, a situação de extrema pobreza e exclusão ainda aparece forte na vida na cidade. As oportunidades que a cidade oferece e sua estrutura social, como escolas e hospitais, entre outros, são interpretadas como conquistas e diferenciais que o campo não tem ${ }^{89}$, embora reconheçam os problemas de acesso a esses serviços na cidade ${ }^{90}$. De certa forma, isso revela as transformações internalizadas e que favorecem a estrutura capitalista através da consolidação da sociedade de consumo dirigida.

\subsubsection{Origem dos migrantes}

Com a industrialização pós 1950, Cubatão recebeu muitos trabalhadores migrantes, a maioria de procedência rural e nordestina, absorvidos, em grande parte, pela indústria de construção (DAMIANI, 1984). Enfim, conforme as circunstâncias encontradas (redes sociais) e de acordo com o alto poder de absorção do mercado de trabalho da época no local, esses trabalhadores foram incorporados ao contexto industrial. Esse fluxo se iniciou de maneira significativa com a construção da Rodovia Anchieta, em 1942, ganhando expressão no período de instalação das indústrias: primeiramente a Usina Henry Borden, seguida pela Petrobrás e a Cosipa.

\footnotetext{
${ }^{88}$ A distinção entre "melhorar de vida" e "subir na vida" é dada por Sarti (1995, p. 12): "Subir na vida significa adquirir novos valores, rompendo com as obrigações de reciprocidade, que fundamentam sua pertinência a seu grupo social de origem".

${ }^{89} \mathrm{Um}$ entrevistado salientou a precariedade do campo, nesse sentido. Pois, caso ele precisasse ser socorrido às pressas, poderia correr risco de vida. As estradas dificultam o trajeto até a cidade mais próxima e os filhos teriam que estudar em locais distantes.

${ }^{90}$ Uma entrevistada mencionou as horas nas filas dos hospitais à espera de atendimento.
} 
A migração aparece como reflexo das transformações na agricultura, resultado do desenvolvimento do capitalismo no Brasil.

Na década de 40, a população de Cubatão foi estimada em 6.570 pessoas, com a segunda fase de industrialização esse número subiu para 11.803, chegando a 50.906 em 1970 (PINTO, 2005) ${ }^{91}$. Entre 1960 e 1970, época em que a cidade recebeu muitos migrantes, o número de pessoas duplicou.

Conforme dados apresentados por Peralta (1979), em 1970, 67,4\% da população de Cubatão era composta por migrantes. Sendo 18,6\% procedentes de outros municípios de São Paulo, 46,8\% de outros estados, $0,1 \%$ de brasileiros naturalizados e o restante, $1,9 \%$, de estrangeiros. De um modo geral, os migrantes da época vieram de São Paulo, Minas Gerais e Nordeste. A maioria dos nossos entrevistados são pessoas provenientes da Bahia, de Pernambuco, da Paraíba, de Sergipe, de Minas Gerais, e alguns do Rio Grande do Norte e do Maranhão, além de uma quantidade pequena de pessoas oriundas de outros Estados.

Não só os aliciadores eram responsáveis pelo recrutamento de forma direta e indireta ${ }^{92}$ da mão-de-obra, como as redes sociais desempenharam um grande papel na contratação de migrantes camponeses.

\subsubsection{Redes Sociais}

As redes sociais se apresentariam como uma base auxiliadora na reprodução do capital a partir da mobilização da força de trabalho, uma vez que o trabalhador vai em direção ao local destinado pelo capital, e aciona as referidas redes. Pois, não só existe um açambarcamento pelo capital de formas arcaicas de produção, mas também de relações sociais inerentes a tais formas. Assim, poderíamos dizer que os vínculos de amizade e de famílias contribuem no processo de proletarização do migrante, enfim da mobilidade de sua força de trabalho.

\footnotetext{
${ }^{91} \mathrm{~A}$ fonte utilizada pela autora foram os dados do IBGE. Segundo este, a população atual de Cubatão é de 108.309 habitantes (Cf. Censo do IBGE do ano 2000).

${ }^{92}$ Há relatos que mencionam o pedido de indicação de trabalhadores conterrâneos por alguns chefes a seus subordinados.
} 
Quando perguntamos aos nossos entrevistados sobre a opção de buscar emprego em Cubatão, ou mesmo por que escolheram Cubatão para morar, a maioria das respostas destacou os vínculos de parentesco ou amizade com pessoas que já moravam e trabalhavam na cidade. Muitas vezes, quem viabilizava a migração era um parente ou amigo que voltava a passeio no local onde o sujeito vivia, roça ou cidade pequena do interior, e transparecia ou falava das possibilidades de ganhar dinheiro e "mudar de vida". Isso despertava o interesse da população local que vinha "na sombra" dessa pessoa, quando não viajava com o conhecido/amigo/parente assim que ele retornava, aproveitando o apoio oferecido.

(...) Ficou difícil pra gente... Tava uns conhecidos passeando por lá aí falavam assim 'eu to a fim de ir pra lá, será que posso ir contigo?' Aí vamo. Aí a gente entrava na sombra do outro e vinha embora... A turma falava a gente tem nossos barraco lá, né, então.. pode ir que a gente dá um jeito. Então a gente vinha e ficava com eles ai. (Entrevistado pela autora, janeiro/2004).

O indivíduo chegava e era acolhido por quem o indicou, morando em alojamentos com mais cinco ou seis pessoas por quarto, em condições precárias. Muitas vezes, ele conseguia serviço por intermédio dos mesmos ou através de novas amizades. Dado o desconhecimento sobre as possibilidades concretas de emprego, ou seja, informações precisas sobre o mercado de trabalho (DURHAN ,1978).

Sobre a influência de parentes e amigos na orientação dos destinos, temos o relato de um migrante mineiro, que havia decidido ir para Volta Redonda, no estado do Rio de Janeiro, a procura de emprego, uma vez que dois de seus irmãos já estavam trabalhando por lá. Porém, durante a viagem, realizada na companhia de alguns primos que retornavam a Cubatão, foi convencido a mudar o destino de sua viagem. Assim, ele tomou a decisão de ir para Cubatão. Durante um tempo, ele contou com a ajuda desses primos, e se estabeleceu na cidade. Voltou para Minas e casou-se com a noiva que havia deixado lá, levando-a em seguida para Cubatão, onde estabeleceu família. Ele trabalhou em uma empreiteira na área da Cosipa ${ }^{93}$. Depois,

\footnotetext{
${ }^{93}$ Esse entrevistado contou-nos que durante sua jornada de trabalho sofreu um pequeno acidente, e diante do descaso de seus superiores e temeroso ao que mais pudesse suceder, resolveu mudar de emprego.
} 
um dos primos o convidou para trabalhar na Light - onde permaneceu até se aposentar.

A partir desse exemplo, e indo além dele, podemos compreender que a migração não é somente um deslocamento espacial no seu sentido mais estreito, mas uma movimentação no universo social, como nos demonstra Durhan. Conforme a autora, o mundo, o espaço físico, não é uma "concepção abstrata, mas resulta da experiência concreta da coletividade...”, uma vez que:

O universo espacial do homem do campo é formado de lugares onde seus conhecidos estiveram, ou onde moram pessoas de sua relação. Espaço geográfico e espaço social se constituem como uma realidade única, que se apresenta sempre sob esses dois aspectos. (DURHAN, 1978, p. 137)

Nesse aspecto, os grupos sociais e as trajetórias tornam-se, conforme propõe a análise crítica das migrações, categorias de análise - ampliando a mesma ao não considerar apenas o indivíduo e os fluxos migratórios na migração.

Ao chegar no município de Cubatão, muitos se dirigiam à Vila Parisi, favela que ficava ao lado da Cosipa, onde o custo da moradia era o menor da cidade. Mesmo após conseguir um emprego, a maioria ainda permanecia por lá, outros procuravam quartos para dividirem o aluguel, ou, dependendo do emprego que conseguiam, iam para os alojamentos/barracões pertencentes às firmas empregadoras. Conforme os relatos, a Rua Antônio Lemos foi um dos locais no centro que concentrou, durante longos anos, uma grande parcela de migrantes.

O apoio dado ao migrante pelos amigos e pela família facilita seu ingresso no mesmo ramo de trabalho ocupado pelo grupo. A malha informal de informações pode ser um fator de orientação dos fluxos migratórios. E é também uma forma do trabalhador se sentir mais acolhido e protegido, mediando seu ingresso no mercado de trabalho e facilitando o contato com os códigos sociais e morais com os quais ele se defronta na cidade. Damiani (1984) reconhece a presença de parentes, amigos e outras informações de caráter pessoal como motivação para a migração, no entanto, esclarece que isso não significa que tal motivação possa ser definida como ato de vontade livre e independente do migrante - fato discutido anteriormente. Opinião 
semelhante apresenta Peralta no que se refere ao caráter pessoal da escolha do destino do migrante:

Mesmo as mudanças mais radicais e distantes como do sertão nordestino para regiões como Cubatão são efetuadas dentro de uma rede de relações sociais personalistas. O indivíduo vai para onde está seu tio, seu primo, ou parente ou amigo. (PERALTA, 1979, p. 222).

Certamente, a combinação entre a necessidade econômica e as relações sociais aparece como fator de peso na decisão de migrar.

A maioria dos entrevistados era de origem camponesa, e veio direto para Cubatão à procura de trabalho, através de redes sociais ou mesmo sozinhos. Alguns relataram terem passado rapidamente por São Paulo em casa de algum parente ou amigo, mas sem empregar-se por lá. Houve casos de pessoas que foram visitar algum parente/amigo na cidade e resolveram ficar e trabalhar. Embora a cidade não correspondesse às expectativas do migrante, em primeira mão, a cordialidade dos habitantes, em sua grande maioria migrantes, acabava cativando o recém-chegado, que via nessas pessoas "um igual"; os valores morais camponeses, a cultura, o ethos, mesmo não sendo idênticos, pertencem à sociedade tradicional, e consistia num elo comum entre eles. Existem assim representações comuns que são partilhadas. A semelhança de situação era um fator reconfortante, contribuindo para a adaptação do trabalhador à nova realidade, e abrindo possibilidades para a recriação de hábitos e costumes de sua origem, num processo de resignificação. Nesse caso, o espaço social tem papel importante na reprodução da vida do trabalhador migrante que lança mão de vários elementos que vão dar sentido à sua existência.

Essas redes também são acionadas no processo de adaptação e resgate cultural desses migrantes, pois o universo urbano aparece como hostil e estranho ${ }^{94}$. O papel do grupo primário no processo, tanto de integração quanto de interpretação do urbano, é fundamental. Conforme Durhan (1978, p. 219-220), eles agiriam como mediadores entre os indivíduos e a sociedade mais ampla. Para a autora, essa seria

\footnotetext{
${ }^{94}$ No que se refere à adaptação e a obtenção do primeiro emprego, essas redes são citadas por Peralta (1979, p. 225).
} 
a interpretação do novo contexto social: "(...) o único modo pelo qual, na estrutura social existente, é possível ao trabalhador ordenar a realidade e definir suas possibilidades de ação".

Os dados coletados são indicativos de que alguns aparatos institucionais também contribuem para a adaptação, como por exemplo, a escola. Com o passar do tempo, os filhos dos migrantes também se tornam grandes detentores de conhecimento sobre o universo urbano, o que na visão de Durhan subverte a hierarquia da experiência e da sabedoria, que são esteios da autoridade patriarcal.

A passagem de um universo com elementos predominantemente rurais para um universo caracterizado eminentemente como urbano não ocorre sem conflitos, diz Durhan. E a transformação do migrante rural em citadino não deixa de ser, de certa forma, a transformação do trabalhador rural em trabalhador urbano, ela reitera. De modo que, no processo de proletarização o sujeito apresenta graus variáveis de participação na sociedade, que de modo algum pode ser interpretada como simplesmente duas partes antagônicas, mas sim um sistema complexo de relações sociais, que comporta relações capitalistas de produção e as não-capitalistas, considerando todas as contradições que elas encerram.

Segundo Durhan (1978, p. 138-141), o "camponês de modo geral, se sente ignorante e diminuído" na cidade para onde migrou. Justamente porque o universo urbano é visto como centro que emana poder, autoridade e saber, em contraposição do mundo simples no qual ele vive.

Nesse contexto, as pessoas que chegavam em Cubatão eram tratadas como "barriga verde". Segundo um entrevistado, o "barriga verde" era o migrante recém chegado, que não sabia nada sobre a região, nem sobre como as coisas funcionavam por ali. E muitas vezes, a inocência tornava o migrante um motivo de chacota. Esse entrevistado nos contou que, nos primeiros dias em que começou a trabalhar, pediram para ele buscar no almoxarifado um esquadro redondo. Chegando lá o almoxarife disse que não existia esquadro redondo e que eles estavam zombando dele. Então esse almoxarife sugeriu que ele voltasse para a sua área de trabalho e dissesse que havia um só instrumento, que estava emprestado, porém assim que o devolvessem, ele iria buscá-lo. "Agindo assim", disse o almoxarife, "eles vão perceber que você não é tão bobo como eles pensam!". 
Outros casos que evidenciavam a falta de conhecimentos sobre o funcionamento da cidade, ou do serviço no qual estava o migrante, geravam comentários do tipo: "Aí, ta vendo, é 'barriga verde'”. Ou seja: "Da roça".

A transformação desse sujeito social em proletário pode ser demonstrada a partir da figura do peão, que representa a grande maioria dos trabalhadores migrantes em Cubatão. $O$ trabalho do peão é caracterizado pela rotatividade do seu trabalho (temporário), sua migração de uma empresa para outra é uma forma de renovar o cativeiro no qual vive à mercê do capital, segundo Damiani (1984). E para a contratação de sua mão-de-obra, pelo menos até o ano em que a autora realizou sua pesquisa, era também utilizada uma rede não oficial de aliciamento de trabalhadores, o mercado de peões - também chamado de mercado de escravos. $O$ mercado de peões funcionava nos logradouros públicos, mas foi proibido de funcionar através a lei municipal o․ 1282, de 17 de março de 1981. Durante seu trabalho, a autora chegou a recolher relatos que afirmavam ainda sua existência. Em linhas gerais, o que Damiani constatou, e o que também pudemos observar durante nossos estudos, foi a situação precária e de exploração do trabalhador de Cubatão. E é dessa forma que ele se insere na cidade.

Ser chamado de peão, na interpretação de alguns entrevistados, era uma forma de tratamento agressivo com as pessoas, que estabelecia uma diferenciação entre o trabalhador urbano qualificado e o matuto (mão-de-obra desqualificada). Nesse sentido, as relações de trabalho aparecem para o camponês migrante de forma diferente: na roça e na cidade. Na roça o trabalho era árduo, duro, mas também associativo, como por exemplo, o mutirão, festivo, com momentos de contemplação, integrado à natureza, não fragmentado. $\mathrm{O}$ trabalhador estaria submetido às relações familiares, próximas; relações de tratamento respeitoso, com caráter de partilha e ajuda. Já o trabalhador na cidade aparece como sujeitado. $O$ trabalho tem o caráter de sujeição formal; as relações refletem, em grande parte, a ordem distante: relações societárias, impessoais, com uma base burocrática - ainda que exprimissem, no decorrer do processo de proletarização, relações paternalistas, de ordem próxima.

Geralmente, a primeira impressão era positiva, já que para muitos, o peão era aquele que montava em burro selvagem, bravo. 
Considerando a exploração da mão-de-obra, mas destacando a abertura do mercado de trabalho no município de Cubatão, tomemos o relato de um entrevistado referente a 1964, anos em que chegou à cidade:

Eu cheguei a fazer vinte e um ano aqui. Eu fiz vinte ano em junho, cheguei aqui dia nove de maio, já trabalhei dia onze de maio, fichei dia onze. Rapidinho, chegava aqui já aí, já tava trabalhando. Naquele tempo era bom. Cê vê, na primeira vez que você pegou a carteira num lugar e foi pra outro já fichou e já trabalhou até sete horas da noite. Trabalhei o dia todo! Hoje a primeira coisa é ter que dar currículo. (Entrevistado pela autora, janeiro/2004)

Nesse relato apreendemos a mudança da dinâmica do trabalho em Cubatão. Percebemos a facilidade da obtenção de um emprego, há, aproximadamente quarenta anos, quando ao procurar trabalho, o indivíduo contava com seu esforço, seu corpo, seu movimento, seu deslocamento, suas redes. Embora a falta de qualificação os levasse, muitas vezes, ao trabalho temporário, permanentemente temporário ou a ter condições de trabalho precárias. Mas muitos também conseguiram emprego nas grandes indústrias, o que lhes deu certa estabilidade e, posteriormente, uma aposentadoria.

O entrevistado exprime a percepção da mudança e isso lhe causa estranhamento. A impessoalidade, de forma cada vez mais acentuada nas relações de trabalho, deixa clara a evidência da força de trabalho como mercadoria, objeto a ser apropriado pelo capital. A sociedade do trabalho se transforma e as relações já não são mais as mesmas. A experiência vivenciada com o trabalho já não é mais a mesma. A preocupação com uma educação que prepare o indivíduo para o mercado de trabalho apareceu em algumas narrativas, principalmente quando as oportunidades de trabalho quando chegaram em Cubatão e hoje são comparadas, visando no futuro de seus filhos na cidade. Eles reconhecem a necessidade da especialização. A concorrência seria um outro fator envolvido na mudança.

\subsubsection{Desenraizamento, Exclusão e Resistência}

Para Heidemann (1998), o migrante é desenraizado ("forçadamente desenraizado") e está sempre em busca do novo e do outro, sendo um agente potencialmente 
capaz de promover transformações sociais, econômicas e culturais. A idéia de desenraizamento é definida por Martins como a destruição das relações tradicionais que sustentam a identidade do sujeito, o que ele era e o que estava acostumado a ser, transformando-o em mera força de trabalho, produtor e, em tese, consumidor das mercadorias produzidas por si próprio.

Quem produz, diz Martins, não é necessariamente quem compra. Portanto a problemática estaria na inclusão, salienta, pois "estamos vivendo um momento perverso do mercado" (MARTINS, 1998, p. 22). A demora ${ }^{95}$ para voltar a ser, além de produtor, um consumidor, qualificaria o trabalhador como um "consumidor marginal”, o que na visão de Martins, também seria essencial à reprodução do sistema capitalista. A interpretação do fenômeno "exclusão", tomado como fator isolado, seria uma ficção, pois "toda a dinâmica dessa sociedade se baseia em processos de exclusão para incluir" (MARTINS, 1998, p 19). A sua inclusão se apresenta como uma inclusão excludente ${ }^{96}$, perversa, contingente (DAMIANI, 2005) ${ }^{97}$, marginal ${ }^{98}$.

Segundo Martins (1998, p. 19), o problema estaria em discutir as formas de inclusão, de modo que: “(...) o que a sociedade capitalista propõe hoje aos chamados excluídos está nas formas crescentemente perversas de inclusão, na degradação da pessoa e na desvalorização do trabalho como meio de inserção digna na sociedade".

As necessidades surgidas a partir da industrialização não são plenamente realizadas, pois a ambigüidade diante da sociedade de consumo se instaura, uma vez que oferece, mas não permite ter, tornando inacessível o que parece próximo. É a lógica da exclusão que se estabelece. E o trabalhador expropriado, o migrante, enfim, as classes subalternas, são os que mais se expõe a isso.

\footnotetext{
${ }^{95}$ A variável "tempo".

${ }^{96}$ A autora Cynthia Andersen Sarti (1995) utiliza o termo "participação excludente" quando trata da relação entre pessoas de baixa renda e o consumo, assim como Martins.

${ }^{97}$ A autora também fala em inclusão perversa (DAMIANI, 1999 b) e em inserção precária (DAMIANI, 1999 a).

${ }^{98}$ Eunice Durhan (1978) utiliza e expressão Integração Marginal nesse mesmo sentido, e inserção tangencial.
} 
No processo de mobilidade forçada o migrante acentua ainda mais sua condição de excluído. A privação vivenciada na atual sociedade pode encerrar o possível. Essa idéia é corroborada através do pensamento exposto por Martins (1998), ao mencionar um componente dessa situação de exclusão e miséria: "a desesperada tentativa de criar, no meio dessa situação, o sentido da alegria", diante do "estreitamento das possibilidades de ascensão social", "das oportunidades de vida" que estamos vivendo atualmente. Vejamos como esse autor esclarece essa idéia:

Refiro-me à reinvenção da alegria, reinvenção do sentido da vida, que faz da excludência um desafio de criatividade e de resistência ao cinismo imitativo que está no centro da mensagem dos meios de comunicação de massa (...), os que se preocupam com as migrações não têm, geralmente, maior interesse pela migração cultural embutida nesse processo. (MARTINS, 1998, p. 28)

Ao destacar a migração cultural como componente importante nos estudos sobre migração, o intuito de Martins é demonstrar o potencial que esse conceito carrega. Os elementos dessa migração cultura/ ${ }^{99}$, aqueles que se referem à cultura de origem do migrante, também migram com ele. Martins questiona o significado desse resgate ${ }^{100}$ cultural; o interesse das pessoas em resgatá-los em outro contexto social, que na maioria das vezes é uma cidade, uma realidade distinta, que insiste em destruí-lo e isolá-lo. Seria, ele diz: "seguramente um componente de resistência", dada a "integração patológica e excludente" que visa a manipulação cultural dessa população através dos meios de comunicação de massa. Estaríamos diante de um

\footnotetext{
${ }^{99}$ A mobilidade cultural da qual Martins fala poderia ser comparada à Mobilidade Simbólica tratada por Hermilio Eduardo Pretto, ao destacar os valores simbólicos fundamentais para o migrante, que não se perdem, mas são flexibilizados numa unidade simbólica, justamente porque as pessoas mantêm o dinamismo do processo. Mesmo precisando estabelecer-se, o ser humano precisa se manter a caminho, esse dinamismo do movimento seria então necessário para que ele viva com dignidade. A mobilidade factual (...) de certa forma inspira a mobilidade simbólica. Os símbolos, segundo Hermilio, mudariam sua força de apelo, com um maior ou menor destaque conforme as circunstâncias objetivas. E quando expressam a dignidade humana, sua tendência maior é não desaparecer. No caso de um desejo ou mesmo efetivação de uma vida estável, os valores simbólicos podem ser mantidos e transmitidos de geração a geração. Porém, segundo Hermilio, numa situação de vida sedentária, o povo deve demonstrar criatividade se quiser viver com dignidade. Por isso, a própria mobilidade funcionando como estímulo externo impulsionaria o dinamismo que viabiliza o progresso. No caso do encontro de culturas a coerência interna não é perdida. Estas idéias foram apresentadas durante uma oficina sobre "Teologia da Mobilidade Humana" no I Seminário Latino Americano de Teologia e Migrações realizado nos dias 18 e 20 de abril de 2006, no Instituto São Paulo de Estudos Superiores (ITESP).

${ }^{100}$ Martins usa o termo transplante cultural.
} 
novo colonialismo, segundo Martins, uma colonização das mentalidades. E "quando a população reage no meio urbano com a sua própria cultura arcaica e agrária, ela está se recusando a essa manipulação." (MARTINS, 1998, p. 33)

O que se coloca, portanto, é uma discussão sobre o modo de inserção na modernidade, que caracteriza o trabalhador assalariado na cidade de Cubatão. $\mathrm{O}$ tipo de proletarização ocorrida com esse sujeito social destaca o caráter familial no processo migratório e nas relações de trabalho, transpondo relações sociais de referência camponesa para o universo urbano, industrializado.

Dada as circunstâncias de utilização das redes sociais, e a produção do espaço durante o processo de proletarização, pode ser considerada a continuidade ou recriação de práticas e valores camponeses no contexto urbano. As contradições do capital estão postas: as diversas temporalidades e o desenvolvimento desigual e combinado, engendram comportamentos e espaços complexos.

A trajetória do trabalhador migrante em Cubatão revela uma história constante e geral de inclusão e exclusão do sujeito no mercado de trabalho. Dado que sua permanência na cidade só foi possível através da pobreza que o caracteriza e das favelas que o abriga. A campesinidade atravessa essa história de fragmentação, angústias, esperanças, decepção e ambigüidade e, ao mesmo tempo, possibilita a recriação dos valores morais do migrante, sua resignificação, a tentativa de restabelecimento do uso sobre o valor de troca, enfim, um embate dado no processo de proletarização que se espacializa de forma crítica e contraditória. Trazendo para o urbano, a discussão do rural na organização da cidade de Cubatão - onde tempos e espaços se misturam, onde as diferenças e a espontaneidade chamam a atenção para os resíduos.

A especificidade do processo de proletarização em Cubatão aponta claramente uma ambigüidade instaurada. Percebemos que, ao mesmo tempo em que o migrante era introduzido no universo urbano a partir das redes sociais, também apresentava algumas resistências e reservas quanto ao conteúdo simbólico do mesmo. Assim, a própria rede que serviu, e serve, como sua mediadora nessa adaptação também the garante respaldo. Os arranjos sociais vão sendo compostos aos poucos; as relações vão sendo resignificadas e no processo de sua espacialização, a tentativa de realização de desejos e paixões referentes a seu universo de origem passa a fazer 
parte de seu conflito cotidiano. As atividades agropecuárias que encontramos no espaço cubatense dizem respeito não só a uma necessidade de sobrevivência frente ao processo de exclusão criada pelo capital, mas também a uma tentativa de recriação de um tempo que se viveu num dado espaço. A busca do sentido da alegria de uma vida que era menos fragmentada, de sentido mais diverso e profundo.

A formação de um urbano com expressões rurais seria uma tentativa de adaptar a atual realidade em que esses indivíduos vivem às suas reais necessidades; necessidades híbridas ou talvez melhor explicadas como ambíguas, como nos propõe Martins (2000, p. 50): “(...) uma cultura arraigada, marcada por uma lógica assimilacionista e integradora, capaz de juntar o diverso e, sobretudo de conciliar o antagônico como forma de resistir à inovação e à transformação".

O trabalho na roça aparece como duro, árduo, de produção incerta e mal remunerada, entretanto há uma tentativa de sua recriação em outro espaço, que é o espaço do trabalho com características aparentemente opostas. Quando os entrevistados falam do trabalho na horta não se referem ao trabalho em si, mas a todo o universo simbólico que este evoca. Os sonhos, a partilha, a comunidade, as festividades, o tempo lento, conforme Maia (1994), o desejo de estar no campo dentro da cidade, recriando e preservando subespaços rurais; mesclando práticas sociais, culturais e econômicas, dando sentido à sua existência. 


\section{Capítulo 3. Campesinidade}

\subsection{Espaço rural e espaço urbano}

A forma e os conteúdos de Cubatão sofreram muitas modificações a partir do processo de industrialização. O não reconhecimento e a não definição de uma Zona Rural no município de Cubatão colocam muitas questões pertinentes à análise do mesmo, uma vez que existem espaços e elementos rurais na cidade. Nosso estudo se torna importante porque considera tais características específicas desse espaço como elementos significativos na análise sobre Cubatão.

Em entrevista realizada com funcionário da prefeitura obtivemos informações de que, antes de instituírem o Plano Diretor de $1998,{ }^{101}$ chegaram a aprovar uma lei que previa uma área rural. No entanto, durante várias revisões desse mesmo plano, acharam por bem extinguir a Zona Rural, considerando o crescimento demográfico do município e a pouca quantidade de espaços que poderiam ser utilizados na urbanização.

Antigamente era assim, Cubatão tinha área urbana e área rural, depois como foi fazendo esse crescimento industrial aqui, acho que em 1969 que foi implantado o primeiro plano diretor, eles adequaram as áreas para crescimento industrial. (Entrevistado pela autora, maio/2006)

A situação dessas terras no município merece um estudo aprofundado, o que não pudemos desenvolver em nossa presente pesquisa. Ainda assim fizemos algumas considerações a esse respeito.

A área rural foi sendo modificada; grandes áreas foram desapropriadas para abrigar as indústrias, outras foram compradas. A maior parte da área rural se localizava ao longo da Serra do Mar, indo desde o Vale dos Pilões até onde se localiza a Cosipa já na divisa com as terras continentais de Santos. Na interpretação de Goldenstein (1965), a zona industrial tendeu a se desenvolver em terras da encosta da Serra do

\footnotetext{
${ }^{101}$ Com relação à Lei Orgânica do Município, esta foi aprovada em 09 de abril de 1990.
} 
Mar, à margem esquerda do Rio Cubatão, na tentativa de encontrar terras mais firmes e talvez materiais para aterros.

O próprio Quilombo existente hoje, próximo a Cosipa, nas terras continentais de Santos já pertenceu ao município de Cubatão, a população do local toma inclusive, Cubatão como referência, utilizando todos os serviços disponíveis na cidade. Segundo moradores, a prefeitura de Santos fornece apenas o transporte escolar para levar os alunos residentes no Quilombo até as escolas de Cubatão. Segundo depoimentos, a relação dos quilombolas com a cidade de Santos é mínima, resumindo-se apenas às obrigações eleitorais, e demonstram uma vontade de reanexação do território ao Município de Cubatão. No Quilombo existem vários sítios com atividades agropecuárias. Um dos entrevistados afirmou cultivar verduras e vendê-las para um restaurante na cidade.

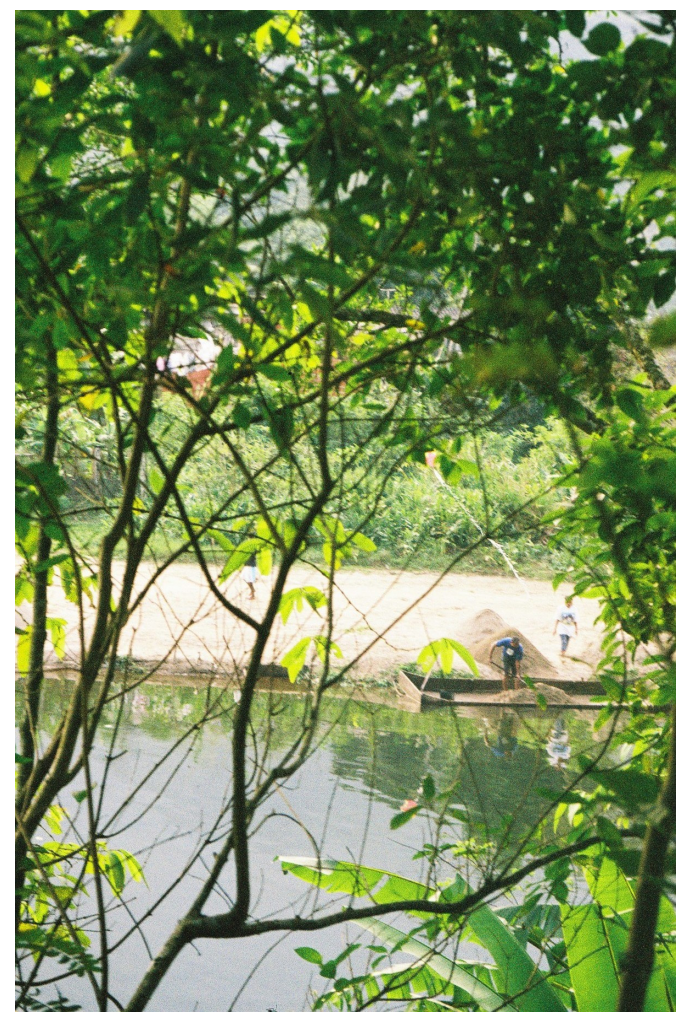

Figura 7: Extração de areia realizada na margem esquerda do rio Cubatão próxima ao bairro Água Fria. (Data: 21/07/06) Fonte: Foto Vilma Aparecida da Silva

Contíguo a Serra do Mar, indo em direção aos Pilões, encontra-se o Parque Ecológico do Perequê.

$\mathrm{Na}$ área denominada de Areais $^{102}$ existem aproximadamente 22 casas, poucas estão ocupadas, devido à remoção das pessoas que ali residiam para 0 Conjunto Habitacional Mário Covas, ao lado da Vila Natal. No local, presenciamos pequenas plantações, em sua maioria hortas e bananeiras e alguns animais de grande porte como cavalos, bois e vacas, além de algumas galinhas e porcos. O bairro Água Fria se localiza à margem esquerda do Rio Cubatão e é cortado por uma das estradas que dão acesso ao Núcleo ItutingaPilões ${ }^{103}$. Ele é considerado área de

102 Área localizada às margens do rio Cubatão nas proximidades do Conjunto Afonso Schmidt e indústria Carbocloro. Inclui o Sítio Capivari, perfazendo um total de 13 hectares.

${ }^{103}$ Pertencente ao Parque Estadual da Serra do Mar. 
invasão. Numa parte da faixa de casas que margeiam o rio encontramos a atividade de extração de areia, conforme observamos na foto à esquerda feita a partir da margem direita do rio.

Prosseguindo pela margem esquerda, antes de acessar o Núcleo Itutinga-Pilões, observamos pequenas propriedades com algumas atividades agrícolas ${ }^{104}$.

A partir do segundo acesso ao Núcleo Itutinga-Pilões, à margem direita do Rio, existe uma ocupação. Seguindo em direção ao Núcleo encontramos pequenos sítios e algumas casas bem construídas.

Segundo a administração do Parque Estadual da Serra do Mar, a área que margeia o rio Cubatão é uma área de ocupação irregular, pois pertence ao Parque, que reconhece dentro dele, pouquíssimas propriedades como particulares.

Toda a área descrita acima era considerada como área rural, passando atualmente a ser uma Zona de Reserva Ecológica (ZRE) que se estende até quase onde é hoje o centro da cidade, margeando morros adjacentes, apresentando características específicas de ocupação com atividades diversas.

As zonas do município (Mapa 3) são compostas por:

- Zona de Reserva Ecológica;

-Zona de Preservação Ecológica;

- Zona de Interesse Público;

- Zona de Comércio Central;

-Zona Industrial;

- Zona Residencial.

104 Durante o levantamento de dados, ficamos impossibilitados de fazer registros nessa área por razões burocráticas do Parque. 


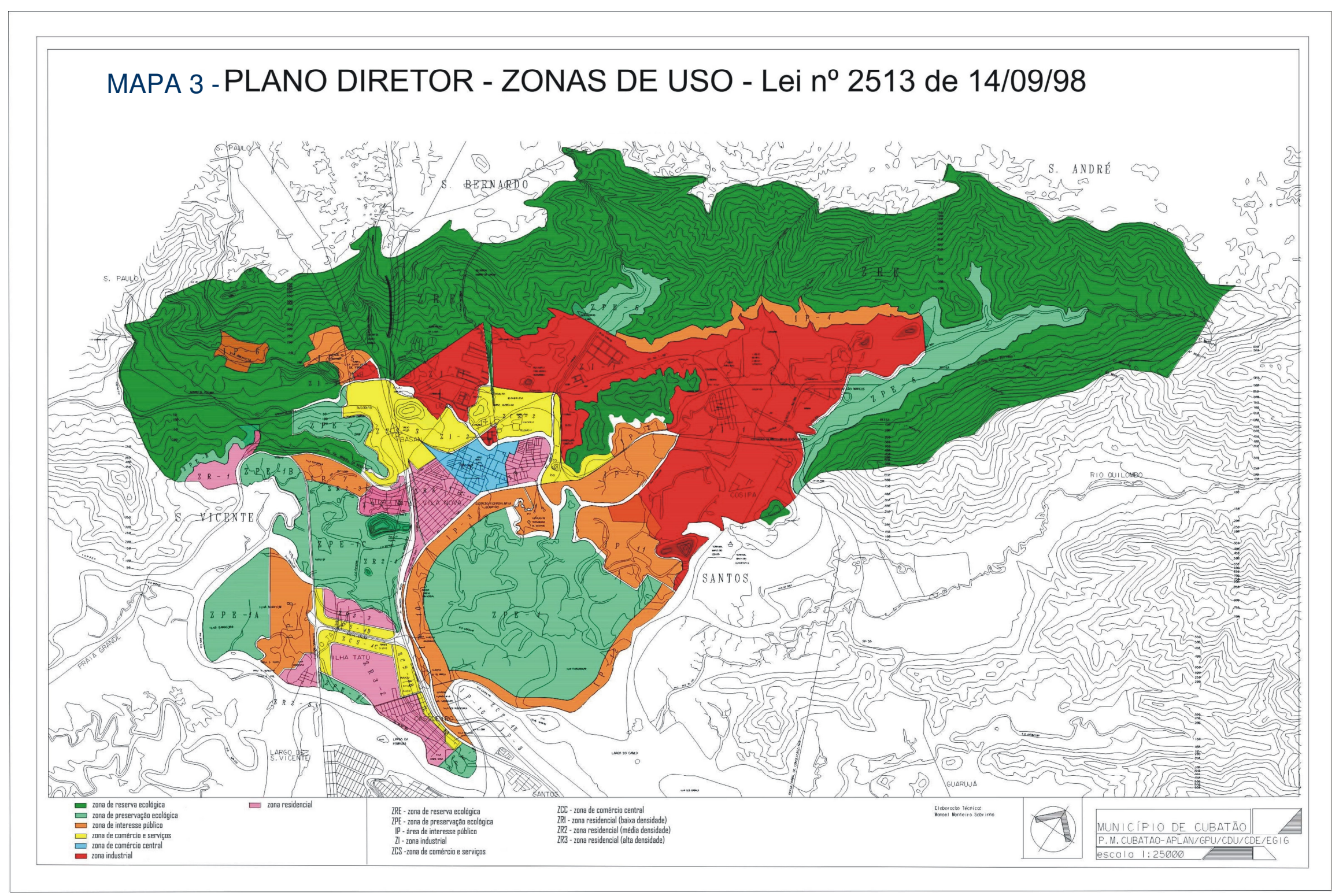


Para a instalação do Pólo Industrial, muitas modificações foram feitas, e as áreas rurais do município passaram a ser consideradas áreas urbanas, embora muitas delas ainda sejam tributadas pelo Instituto Nacional de Colonização e Reforma Agrária (INCRA) (algumas não têm registro em cartório em Cubatão). A prefeitura ficaria então, impedida de fazer a tributação como área territorial ou área urbana, porque corre o risco de bi-tributação. Ela teria que, primeiramente, cancelar as essas áreas inscritas no INCRA para depois tributá-las. Essas áreas se localizam no bairro Pilões e teriam aproximadamente de dois a três milhões de metros quadrados, segundo o funcionário, que acrescenta que a área urbana teria em torno de 34 milhões de metros quadrados, incluindo as favelas. Parte da área do Parque Estadual da Serra do Mar (67 a 68\%) é considerada como Zona de Reserva Ecológica.

As áreas do município estariam assim divididas: 25\% área de mangue, 57\% de serras e $18 \%$ de planície e mangue aterrado ${ }^{105}$. A área industrial ocupa em torno de $35 \%$ do total da área do município $\left(148 \mathrm{~km}^{2}\right)$.

Segundo o entrevistado, as áreas influenciadas pela maré, como áreas de mangue e as ilhas, pertencem ao Serviço de Patrimônio da União (SPU). O município conta com 77 áreas inscritas e registradas no Registro Imobiliário Patrimonial (RIP) cadastradas no Serviço de Patrimônio da União.

No caso das terras dos Pilões, vigora um decreto de restrições e os moradores da área entraram com uma ação indenizatória contra a Prefeitura, que reivindica a área para a preservação dos mananciais. A própria criação do Parque Itutinga-Pilões figura como uma tentativa do poder público em preservar a área, porém a prefeitura reconhece que poucos recursos são empregados para viabilizar esse projeto; mesmo porque essa área entraria no processo de valorização da terra. Portanto, é uma área que apresenta uma série de conflitos envolvendo a Prefeitura, o Estado e os moradores locais.

Como o crescimento da cidade está planejado conforme o zoneamento já mencionado, percebemos um grande problema: a falta de determinação de uma zona rural - necessidade expressada por grande parte de nossos entrevistados. Um

\footnotetext{
${ }^{105}$ Dados confirmados no trabalho de Pinto (2005).
} 
deles declarou que as autoridades esqueceram que Cubatão precisaria de um espaço rural para a população criar uma cabra, uma vaca, uma galinha... E que atualmente, mesmo se a prefeitura quisesse fazer uma 'mini' fazenda ela não poderia, por não ter definido uma área rural. Sobre isso o entrevistado disse discutir muito com as autoridades, dizendo que a Câmara tinha que fazer um projeto de lei e estabelecer:

Olha, essa área aqui é rural. Então nessa área aqui você pode criar, nessa área aqui você pode ter animal. Nessa área aqui você pode ter criações. E não conseguimos. Mas aquilo ficou sempre no limite. E aí começou outra atividade na cidade. O quê? O Cavalo. (José Severino da Silva ${ }^{106}$, junho2006)

Em outra entrevista essa discussão também pode ser exposta:

Falta o município revogar essa maldita lei de que Cubatão não tem zona rural. Determinar quem é dono de sítio, os seus sítios, deixar que seus sitiantes vivam e essa lei tem que ser revogada e esse é o certo! E eu não estou falando só por mim, compreende? Porque veja bem, amanhã... Eu vou pra qualquer um outro lugar, compro outro lugar e vou viver pra lá. Mas acha que é bonito isso? Acha que... Então imagina como me dói. Pô, eu vivi minha vida toda aqui, eu pago meus impostos é aqui. Eu vivo é aqui. Porque que agora eu tenho que ir embora se eu quero continuar minha vida? Você não sabe a perseguição que o trabalhador sofre aqui em Cubatão, o trabalhador da terra, que eu me refiro... Em vez de se incomodar com outras coisas que não levam a nada, devia, ao invés de querer tirar a zona rural, deviam ao contrário: Demarcar a zona rural e incentivar a criação, incentivar a plantação, sabe! la diminuir muito a pobreza, nossa! la diminuir muito a violência porque criança criada na terra não fica violenta. Criança da terra vai ser da terra sempre. E o município não entende isso. Infelizmente, nossos governantes não percebem isso e nos perseguem. Perseguem os criadores. Eu acho que, ao invés de perseguir o criador e tirar o pouco de zona rural que nós temos, devia implantar, determinar uma área. O prefeito não, que

${ }^{106}$ O entrevistado autorizou a divulgação de seu nome. A entrevista com José Severino (Miúdo) encontra-se na íntegra no Anexo C, considerando a relevância do seu depoimento. 
ele é uma pessoa que pessoalmente, é uma pessoa excelente, entendeu?! Eu falo é do município! (Entrevistado pela autora, maio/2006)

Em geral, as pessoas demonstram certa simpatia pelo prefeito e acusam 0 município, o poder legislativo, pela não delimitação de uma área rural. Não só a população demonstra a necessidade da zona rural, como essa expressão acaba se refletindo em outras formas de uso e apropriação da cidade. Um exemplo seria a criação de animais, principalmente porcos, cabritos, víveres, ovelhas e cavalos na cidade. Uma atividade proibida pela Prefeitura, através da Vigilância Sanitária, autuar os donos de animais. A ação reflete a racionalidade do Estado na organização e produção do espaço. Sobre criar animais no município, uma entrevistada relata:

Eu não tenho bem certeza, mas eu acho que foi no ano de 1983, que o então prefeito instituiu a lei orgânica de não ter animais de grande porte na cidade. Para nosotros criadores de grandes animais foi um golpe muito forte, eu mesma fui prejudicada de uma maneira tão forte que tive... Eu tendo uma área imensa - que eu tenho uma área imensa, né, eu fui obrigada a retirar meu cavalo de estimação, fui obrigada a comprar um lugar fora. Eu não tinha condições, peguei empréstimo, fiz o diabo para comprar uma casa na cidade de São Vicente pra colocar meu cavalo, porque eu tinha que escolher: ou eu cuidava do meu bicho ou eu dispensava ele.

Então porque quem vive da terra, quem é da terra, quer terra. $\mathrm{E}$ quem é educado da terra não se perde. Então o que aconteceu? Quando foi instaurada essa lei orgânica pra mim foi um golpe muito grande. Para os outros, creio eu, bem pior. Mas aqui eu sobrevivi a isso. Outros sobreviveram e nós estamos aí mantendo nossos animais clandestinos... E como eu, existem muitos outros dentro da mesma situação... Aqui o pessoal quer plantar, mas o município não quer que plante. O município insiste que não. (Entrevistado pela autora, maio/2006)

Segundo depoimento de um funcionário da Vigilância Sanitária este órgão deve garantir a valorização do espaço urbano e primar pela qualidade dos alimentos 
produzidos $^{107}$, entre outras questões. Recentemente pode-se falar em aproximadamente 138 ocorrências na cidade relativas à apreensão de animais.

A necessidade de ter um pedaço de terra para plantar, para criar um animal, dentro do perímetro urbano ou de modo geral, no município aparece em muitas falas. Muitos entrevistados não fazem diferença quanto à forma do rural e a forma do urbano, ou seja, para esses entrevistados caberiam perfeitamente atividades rurais na cidade de Cubatão. Por exemplo: a cidade enfrenta problemas com pessoas que criam cavalos, especificamente, por ser um animal de grande porte, de carga, que acaba circulando pela cidade, se comparado com vacas e cabras, entre outros, que tendem a permanecer num só local. Essas pessoas entendem que os espaços públicos são públicos, isto é, podem ser apropriados pelos habitantes da cidade, por isso, deixam os animais pastando em vários locais. Às vezes, os animais podem ser encontrados em espaços extremamente inusitados, por exemplo, pastando na frente do Fórum, nas imediações da Prefeitura e de Órgãos Públicos. A Associação dos Cavaleiros de Cubatão tenta resolver essas questões, mas sem êxito na maioria das vezes, conforme relato:

Então muitos deixam os animais soltos em qualquer lugar. Muitas vezes você vê um animal cruzando a Avenida Nove de Abril, outra vez você vê um animal em frente ao Fórum, tudo isso dá problema para a Associação. Então a gente vai lá, pega o animal, procura quem é o proprietário, o proprietário muitas vezes acha ruim porque a gente tirou o animal de onde estava. Só que ele não sabe que o animal não é para ficar dentro da cidade, é para ficar num sitiozinho, entendeu? Algum lugar mais afastado do centro da cidade e muitos não respeitam, então a gente tem esses problemas também, entendeu? (Entrevistado pela autora, junho/2006)

$\mathrm{Na}$ entrevista acima o entrevistado sugere que ter um cavalo na cidade implica mantê-lo num local específico, e que existem leis para o uso do espaço da cidade, sendo isto geralmente ignorado, burlado e contestado através dessas ações. Mas

107 Os animais são criados não apenas para o consumo, mas também para a venda, porém, diante dos impasses enfrentados, muitos criadores se mantêm na clandestinidade, conforme relato aqui exposto. 
percebemos que mesmo diante de todo conflito ao redor da questão do cavalo, ele ainda é, de certa forma, tolerado pelo poder público.

O que observamos durante nossa pesquisa é que não existe uma objeção quanto ao desempenho de algumas atividades rurais na cidade. Elas muitas vezes são naturalizadas, expressão de um modo de vida, compatíveis com o morar na cidade; claro que em dimensões apropriadas. Por isso ainda são realizadas, mesmo infringindo as regras estabelecidas para o viver na cidade. A reivindicação de uma zona rural aparece, às vezes, como um pedido de reconhecimento e legalização de propriedades que desenvolvem atividades agropecuárias. E o que se coloca como necessidade maior é a tolerância de hábitos rurais na cidade. No caso das hortas, não existe um conflito aparente entre o poder público e os proprietários de terrenos ocupados com o cultivo de frutas, legumes e verduras. Mesmo porque esse tipo de utilização dos terrenos favorece a manutenção por parte de seus proprietários. Nesse sentido também é respeitada a necessidade dos moradores locais, a menos que estejam situados em locais que comprometem a imagem da cidade, como é o caso das hortas que existiam ao longo do canal Henry Borden, no bairro Jardim 31 de março.

Com a construção da Rodoviária da cidade ao lado desse canal, a criação e manutenção de hortas foram proibidas. No local foram plantadas grama e árvores. Porém, atualmente observamos cavalos pastando na grama colocada. Segundo um entrevistado, mesmo sabendo que Cubatão não tem Zona Rural, os donos de animais "não abrem a mão de tê-los". De qualquer forma, a cidade pressiona o rompimento cultural e simbólico e os hábitos rurais que esses indivíduos apresentam, uma vez que destoam do ethos urbano. Poderíamos então dizer que a forma urbana da cidade de Cubatão, assim como toda cidade, apresenta uma diversidade de conteúdos, mas com destaque para os elementos rurais.

Se considerarmos que, historicamente, a sociedade brasileira se caracterizou pela ausência de uma 'dualidade marcada' entre o campo e a cidade, e que nosso modo de ser apresenta uma complementaridade, uma lógica assimilacionista, o que evidencia a presença da cultura rústica na cidade, conforme nos propõe Maria Isaura Pereira de Queiroz (1973 apud WANDERLEY, 1999), seria plausível pensarmos numa prática urbana permeada por valores tradicionais. Nesse contexto, a distinção entre o urbano e o rural apareceria como que diluída ou evidenciada pela 
forma cidade, enquanto materialidade, versus campo. Contudo, em muitas entrevistas aparece o desejo de união entre os conteúdos do rural e do campo, principalmente no que se refere à cidade.

\subsection{Discussão sobre Espaço Periurbano}

A maior parte da área rural de Cubatão se localizava ao longo da Serra do Mar. Porém, durante o processo de industrialização do município, em 1950, essas áreas foram sendo modificadas, cedendo lugar às empresas, que consideraram a região mais adequada à instalação das indústrias. Na interpretação de Goldenstein (1965), a zona industrial tendeu a se desenvolver na encosta da Serra do Mar, à margem esquerda do Rio Cubatão, numa tentativa de se encontrar terras mais firmes e talvez materiais para aterros. O fato é que essas terras estão próximas aos principais rios que cortam a cidade: Perequê, Pilões, Cubatão, Mogi, Perdido, das Pedras e Piaçaguera. Dentre os rios citados, o rio Cubatão é o mais importante, pois é responsável por cerca de $80 \%$ do abastecimento de água da Baixada Santista. Com uma área aproximada de 177 km², ele nasce em São Bernardo do Campo, atravessa todo o Vale Itutinga-Pilões e recebe à margem esquerda o rio Pilões.

Nosso estudo se iniciou pelo bairro Jardim 31 de março, mas de uma maneira geral consideramos outros dezesseis bairros, além dos Pilões. No entanto, aprofundamos nossa análise em apenas alguns bairros, dada a limitação do tempo de pesquisa.

Tanto na cidade quanto fora do perímetro urbano podemos encontrar atividades agrícolas, por isso não nos restringimos apenas aos bairros propostos inicialmente no trabalho, visto que muitos fatos relativos às atividades agrícolas no município apresentam estreitas ligações com a região dos Pilões.

A diversidade do uso desse espaço levou-nos a considerá-lo em nossa análise, pois, acima de tudo, apresenta atividades agrícolas, seja nos sítios ou em meio às ocupações nele situadas.

O Vale Itutinga-Pilões se localiza entre a Serra do Mar, o Morro da Mãe Maria e o Morro do Marzagão (Mapa 4). 


\section{Mapa 4 - Município de Cubatão - SP \\ Áreas de Estudo}

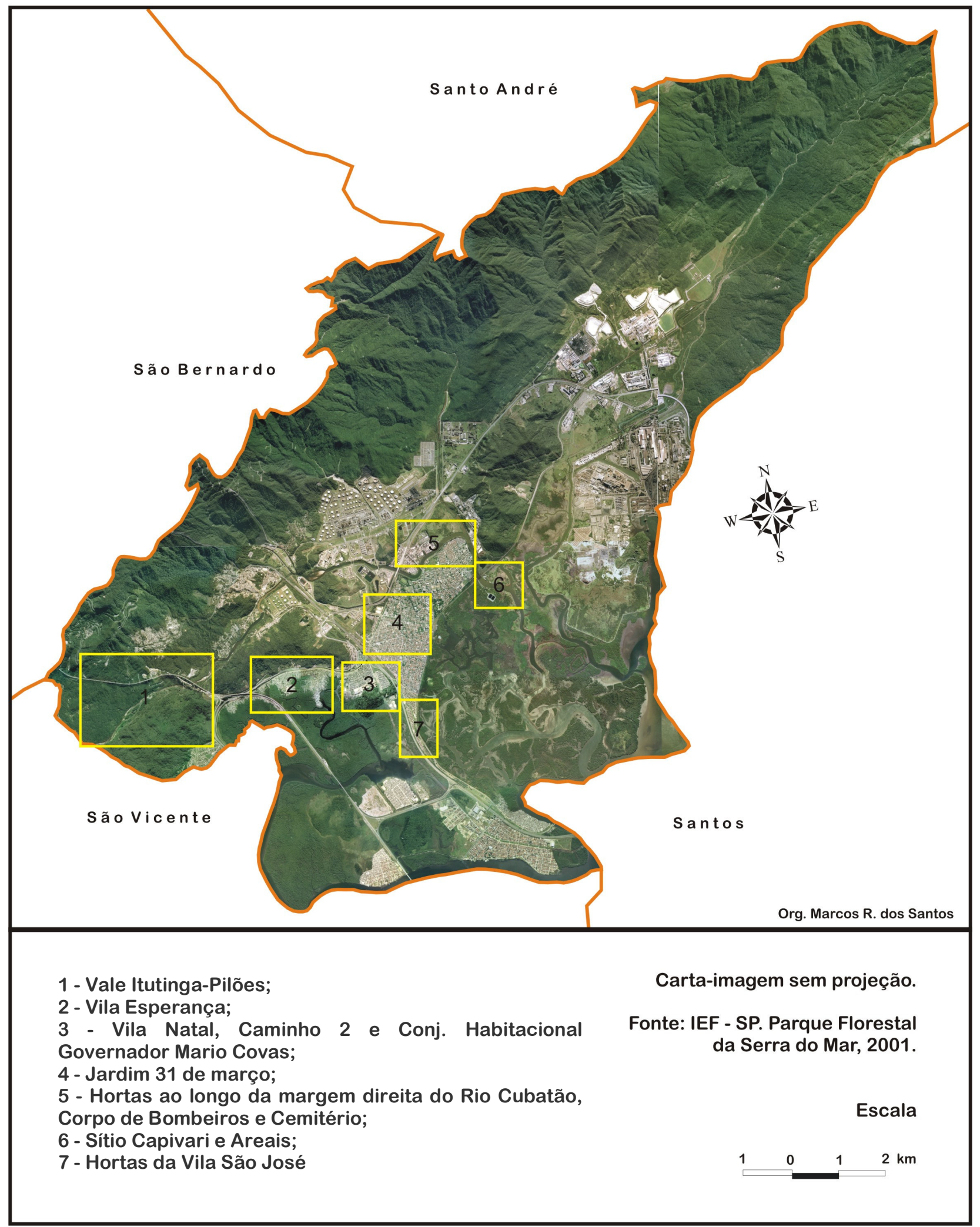


Uma pequena parte do Vale também compreende terras pertencentes ao município de São Vicente. Em Cubatão, a maior parte da área dos Pilões é caracterizada como Zona de Reserva Ecológica, outra pequena parte é definida como Zona de Preservação Ecológica. O Parque Estadual da Serra do Mar abrange grande parte do Vale dos Pilões e é considerado como Zona de Reserva Ecológica.

Embora um pequeno povoado chamado de "Cubatão de cima" tenha se desenvolvido na região, dele, restaram apenas ruínas. Atualmente, a área abriga pequenos sítios, um núcleo administrativo do Parque Estadual da Serra do Mar e três ocupações: Pilões - Invasão Pista Descendente da Via Anchieta; Fábrica de Sardinha e Água Fria ${ }^{108}$. Na tentativa de compreendermos melhor o Vale dos Pilões, nos propomos, primeiramente, a discutir algumas definições referentes a espaço periurbano.

A noção de periurbano, surgiu na França, no intuito de designar comunidades rurais localizadas ao redor das cidades (PEREIRA, 2000). A necessidade de caracterizar os espaços localizados fora do perímetro urbano levou muitos autores a criarem várias interpretações e definições para determinadas situações circunscritas nesses espaços. Assim, cada autor considerado em nossa análise ${ }^{109}$ fornece uma contribuição no entendimento sobre essa reflexão. Alguns apresentam uma concordância de nomenclatura, outros não. Contudo, a apresentação dessas definições se converte no melhor exercício para a interpretação a respeito dos Pilões.

Encontramos definições de espaço periurbano que o destacam como sendo espaços não definidos, híbridos ou de transição (entre o campo e a cidade, nem cidade, nem campo).

Elodie Valette (2004), ao tratar de territórios situados na periferia de Montpellier, na França, define como "periurbanos" os espaços situados em territórios periféricos, tratando-os como "territórios econômicos periurbanos". Embora Elodie reconheça a complexidade desses espaços, eles são interpretados apenas a partir do destaque

\footnotetext{
${ }^{108}$ As ocupações dos Pilões e da Fábrica de Sardinhas ficam à margem esquerda do rio Cubatão, e a da Água Fria fica à margem direita.

${ }^{109}$ Consideramos Vale (2004); Vallete (2004); Roese (2006) e Pereira (2000).
} 
de seus potenciais econômicos. No que concerne ao desenvolvimento de áreas rurais, o fator econômico precisa estar associado também ao social e ao político. Nesse sentido gostaríamos de destacar o texto de Marques (2002), onde ela, entre outros assuntos, trata da questão do desenvolvimento do campo, destacando o valor expressivo de novas experiências para a superação de problemas estruturais da nossa sociedade. $O$ campo não pode representar apenas uma paisagem a ser consumida, mas é um gestor de projetos de desenvolvimento rural em potencial. A partir da situação colocada, podemos entender as possibilidades de se construir um "novo" espaço rural como contraponto crítico dessa sociedade, através de novas formas de organização social no campo, sem deixar à parte a reflexão do urbano e que tem a cidade como palco - entendendo que o campo e a cidade, o rural e o urbano representam uma unidade na diversidade, formando uma só totalidade (dialética).

Nesse processo da dinâmica social, surgem novas formas de produção e de existência, conseqüentemente, abrindo novas perspectivas sobre novas territorialidades. Assim, o território aparece como elemento fundamental na compreensão da relação cidade-campo, salienta a autora, que ao citar Wagner (2001) conceitua território como:

(...) um espaço socialmente construído por um determinado grupo social na produção e reprodução de sua existência. Por isso, ele não cabe dentro de uma divisão político-administrativa (p. 23-25). (MARQUES, 2002, p. 110)

Mesmo diante de várias interpretações, os autores estudados concordam que os espaços periurbanos são definidos como aqueles que se localizam próximos ao perímetro urbano, apresentando atividades agrícolas e não agrícolas. Porém, segundo Vale (2004), ainda não existe um acordo terminológico sobre a porção espacial antes denominada de espaço rural e sobre a qual as cidades acabaram se expandindo. Diante desse impasse, muitos termos passaram a ser utilizados para denominar tal espaço. Entre eles, "rural-urban fringe, banlieue, franja urbana ${ }^{110}$ ou

${ }^{110}$ Segundo Vale (2004), o termo franja urbana é usado quando se trata de áreas com crescimento periférico e onde se misturam usos do solo urbanos e agrícolas. 
rururbana, sombra urbana e espaço periurbano". Dentro desse espaço a cultura citadina se integraria com o meio de vida rural.

Consideremos a definição de franja urbana e de franja rururbana dada por Vale (2004). O termo franja urbana, utilizado pela primeira vez pelo geógrafo Smith em 1937, designaria "uma área construída fora dos limites administrativos da cidade... em áreas de crescimento periférico e onde se misturam usos do solo urbanos e agrícolas" - uma zona de transição entre o campo e a cidade; podendo também ser vista como parte da cidade (JOHNSTON, 1978 apud VALE, 2004). Portanto, não poderíamos considerar um único termo: "franja urbana" - uma vez que existem indícios de atividade rural nesses locais.

Já a segunda denominação, franja rururbana, se refere a um espaço físico que mistura o uso rural com uma configuração característica da cidade, agrupamentos de casas, vias de transporte, estruturas de serviços, entre outros, onde os atributos do campo seriam destacados, como o ar puro e a tranqüilidade, mas que não apresentaria qualquer tipo de integração com as atividades do campo.

A definição dada por Vale é a mesma mencionada no trabalho de Freire (1982 apud VALE, 2004), ao definir rururbanização como uma "mistura" de situação urbana e rural com seus respectivos valores, representados por seus modos de vida.

$\mathrm{Na}$ discussão sobre franja rururbana encontramos outro conceito, a rurbanização. $A$ definição dada por Freire, a coloca como um processo que apresenta certa resistência (ele chega a falar em rejeição absoluta) à urbanização. O rurbano apresentaria uma mescla do rural com o urbano em termos de forma e conteúdo, mas com preponderância do rural, já que Freire destaca traços rurais como determinantes. Já Coelho (1999 apud VALE, 2004) apresenta o conceito de rurbanização como uma nova forma de habitat ${ }^{111}$ adotada pelos citadinos, que continuariam desenvolvendo suas atividades de trabalho na cidade, porém residindo nos espaços próximos à mesma, a essa configuração, ele dá o nome de "migração pendular de trabalho". A menção feita à rurbanização pelo autor é pontual, sem abordar elementos rurais ou urbanos.

\footnotetext{
111 Segundo Henri Lefebvre (1999, p. 80), o termo habitat designa um pseudoconceito caricatural criado pelo pensamento urbanístico do final do século XIX. Esse tipo de pensamento teria desconsiderado o "habitar" - tão relevante na análise do referido autor.
} 
Em relação a questão do habitat, pensamos no trabalho de Seabra (2004), que se refere aos condomínios como uma forma de segregação sócio-espacial inserida no processo de urbanização, produzindo territórios. Esses territórios demonstram uma exclusão social que tem como base a propriedade privada. Seabra esclarece que as formas de segregação sócio-espacial podem se manifestar como auto-segregação, onde os condomínios são territórios que concentram as populações de maior renda.

Zárate (1984 apud VALE, 2004) propõe um significado para rurbano, como sendo uma área situada na zona urbana, onde o rural aparece associado ao urbano e com tendência à valorização, devido ao crescimento urbano; abrigando, contudo, novas formas de reprodução da força de trabalho. Ou seja, um espaço no aguardo de uma urbanização efetiva. Com a tendência à valorização, ela talvez também se caracterize como área de "pousio social".

Tanto o conceito de rururbanização quanto o de rurbanização estão vinculados ao crescimento urbano.

O termo rurbano é também utilizado por Henri Lefebvre (2004). Segundo o autor, esse neologismo foi empregado por geógrafos para designar a situação onde o campo se perde no seio cidade, e ao mesmo tempo pode-se observar a cidade absorvendo o campo e perdendo-se nele.

Descrevendo o espaço periurbano, Corellano (1998 apud VALE, 2004) destaca a infra-estrutura urbana, os espaços rurais, com atividades agropecuárias, e os "espaços naturais" (rios, matas, florestas), que permitiriam um contato com a natureza.

Certamente o espaço denominado de periurbano, apresenta elementos complexos e não se caracteriza pelo isolamento, mas sim evidencia uma interação do rural com a cidade (ESPANA, 1991 apud VALE, 2004), simultaneamente, permeado pelo urbano. 


\subsubsection{O espaço periurbano dos Pilões}

O "Bairro dos Pilões" (Itutinga-Pilões) ${ }^{112}$ se localiza dentro de um Parque Florestal pertencente ao Instituto Florestal de São Paulo. Um espaço que consideramos como periurbano.

Transformada em área de Reserva Florestal em 1977, o local abrigou tanto sítios produtores de bananas, quanto extração de areia, e pequenas propriedades, sítios. Lá também chegou a funcionar uma "fábrica de sardinhas", onde as sardinhas eram enlatadas. Hoje encontramos alguns sítios de bananas, chácaras de final de semana, propriedades de alto padrão, pequenos sítios, favelas, extração de areia e o Parque (Parque Estadual da Serra do Mar). Parte dos Pilões é um local turístico, ainda não muito explorado e divulgado. Há uma parceria entre a Prefeitura e a Administração do Parque para a realização de passeios ecológicos na área, com agendamento prévio, destinados apenas a grupos.

Quem desce a Serra do Mar pela Rodovia "Nova Imigrantes", pode observar a Baixada Santista logo após o último túnel. Dali, podemos ver os longos e grossos pilares da estrada e da Rodovia Imigrantes cravados no Vale dos Pilões. Lá de cima, vemos também o Rio Pilões ao longo do Vale. Nessa mesma paisagem ainda restam alguns pés de eucalipto, vestígios da época em que a Empresa Telles plantava-os com o objetivo de produzir celulose para a Companhia Fabril (1945).

$\mathrm{O}$ acesso aos Pilões pode ser feito a partir de três formas distintas. A primeira é utilizando uma estrada de serviço da Rodovia "Nova Imigrantes", que passa pelos pilares da Rodovia no meio da mata. A segunda é através do Bairro Fabril, passando em seguida pelo bairro Água Fria, e, finalmente, através de uma entrada às margens da Rodovia Pedro Taques, no entroncamento com a Rodovia Anchieta - ao lado de uma Pedreira.

\footnotetext{
${ }^{112}$ O Parque foi criado em 1977. Grande parte do Parque era Reserva Florestal. A área do Parque vai desde Picinguaba (localizada no litoral Norte de São Paulo) até Pedro de Toledo (localizado no litoral Sul de São Paulo). Esse Núcleo recebe, atualmente, grupos de turistas e pesquisadores cadastrados no COTEC - Conselho Técnico do Instituto Florestal de São Paulo. O procedimento do Instituto para a liberação da área para pesquisa consiste em ficha cadastral, envio de projeto e documentos da entidade e professores aos quais o pesquisador está vinculado, levando aproximadamente cerca de 3 a 4 meses de análise do projeto de pesquisa. No momento, portanto, só pudemos fazer algumas observações sobre a área, diante da escassez de tempo hábil para o aprofundamento do trabalho de campo nesse local. Mesmo porque o acesso ao Vale dos Pilões só é aconselhável com acompanhantes autorizados, visto o grau de periculosidade do local.
} 
$\mathrm{Na}$ área dos Pilões, originalmente se localizava a sesmaria dos Pilões, doada por Martim Afonso de Souza a Antônio Rodrigues de Almeida em 1556, que, depois, a doou à Companhia de Jesus em 1643. A partir de então, as terras passaram a ter vários usos e a pertencer a vários donos, indústrias e particulares ${ }^{113}$. O entendimento sobre a questão fundiária necessita um longo estudo, o que infelizmente não podemos realizar no momento. Apenas sabemos que há muitos moradores antigos residindo no local.

Numa outra parte dos Pilões existiam grandes sítios produtores de banana, entre outras frutas (em menor quantidade, quando comparadas com a produção da banana). Segundo Couto (2003, p. 56), "dessa região saía uma produção de laranjas e tangerinas famosas pelo sabor".

Alguns desses sítios foram adquiridos pela empresa Telles na década de 40, que, com o objetivo de plantar eucaliptos, acabou com alguns bananais. No local surgiu uma Vila fundada pelos proprietários da referida empresa, que ali fixaram residência. Chamada de Itutinga, mas também conhecida por "Cubatão de Cima", a Vila contava com capela, hospital e "prefeitura" (PINTO, 2005). No local podem ser vistas algumas ruínas dessa época, onde hoje se localiza a sede do Núcleo Itutinga-Pilões, uma das sedes administrativas do Parque Estadual da Serra do Mar. Algumas terras foram doadas aos trabalhadores do bananal como forma de pagamento.

Diante da falta de melhores opções, e vivendo em condições precárias, os trabalhadores se fixaram nesses locais por um longo período. A cultura da banana, drasticamente reduzida, já não domina mais a paisagem, mas resiste em pequenas propriedades ao longo do Vale dos Pilões e outras localidades pontuais ${ }^{114}$. Nos Pilões encontramos sítios com produção agrícola, em sua maioria com uma

\footnotetext{
${ }^{113}$ A notícia que temos é que havia terrenos pertencentes à RFFSA (Rede Ferroviária Federal Sociedade Anônima, que em 1957 incorporou à sua malha a Estrada de Ferro Santos-Jundiaí) cedidos para alguns funcionários. Atualmente 7 famílias vivem nesses terrenos; há outros terrenos pertencentes à Sabesp e Refinaria Presidente Bernardes. O processo de açambarcamento de terras pelo Estado para repassá-los às indústrias é discutido no sub-capítulo sobre industrialização e urbanização.

114 Durante os anos de denúncia sobre a poluição em níveis altíssimos em Cubatão, descobriram que uma parte do fundo do Vale havia sido contaminada pelo "Pó da China" (resíduo industrial altamente tóxico) depositado por algumas indústrias da cidade. Isso ocasionou doenças na população que ocupava essas áreas. Muitas famílias foram transferidas para conjuntos habitacionais, outras permaneceram por lá.
} 
"produção para aprovisionamento" (GODÓl, 1999, p. 51) (frutas, legumes, verduras, patos, gansos, galinhas, porcos, milho, feijão, apicultura, mandioca, boi, cabrito). Alguns sitiantes vendem banana no próprio local onde moram ou para produtores maiores que vivem no fundo do Vale, já na divisa com o município de São Vicente. Esses grandes produtores compram as bananas produzidas nos pequenos sítios, utilizam estufas para controlar seu amadurecimento, para depois comercializá-las ${ }^{116}$.

Embora as propriedades com uma produção mais expressiva se localizem em terras vicentinas, o sentimento de pertencimento se dá com a cidade de Cubatão, por sua proximidade. Segundo um entrevistado, a ligação dos moradores com a cidade de São Vicente se restringe apenas ao pagamento de imposto sobre as terras. Para quem observa e conhece a área, a área que fica na divisa, ou já em outro município, aparece como parte indissociável do Vale. Isso nos remete à discussão de território como um espaço em que esse grupo produz sua existência; seus vínculos são estabelecidos com Cubatão, sua referência de vida é a cidade de Cubatão. A divisão dessa área entre os municípios de Cubatão e São Vicente aparece como uma divisão meramente político-administrativa, conforme exposto acima por Marques (2002).

No acesso pelo bairro Fabril e pela Rodovia Pedro Taques, podemos encontrar três ocupações. A primeira é chamada de Água Fria, nas proximidades do bairro Fabril, ela está localizada numa região de várzea à esquerda do Rio Cubatão, ao longo da Estrada Elias Zarzur, cruzando pela Rodovia dos Imigrantes, no Vale Itutinga-Pilões; entre a Companhia Santista de Papel e a entrada para a sede do Parque Estadual da Serra do Mar (núcleo Itutinga Pilões). A área é caracterizada como uma antiga ocupação, feita por trabalhadores que se estabeleceram ali durante a construção da Via Anchieta, como extensão das áreas das encostas ${ }^{117}$. Na altura dessa ocupação alguns moradores podem ser vistos realizando extração de areia do rio Cubatão.

\footnotetext{
${ }^{115}$ A autora discute a expressão "produção para aprovisionamento" com base em Sahlins (1970 apud GODÓI, 1999). Essa produção não serviria apenas para consumo próprio, mas também para troca, sendo que o que governa a produção é o que eles precisam e não o lucro que possam obter.

${ }^{116}$ Não tivemos acesso a todas as propriedades, apenas localizamos um produtor que compra bananas de alguns sitiantes e vende-as nas feiras da cidade.

117 Cf. http://www.novomilenio.inf.br/cubatao/ Acesso: maio de 2006 e Coordenadoria do Desenvolvimento econômico de Cubatão.
} 
A Fábrica de Sardinhas, uma das três ocupações, se localiza no Caminho dos Pilões, mas não foi possível realizarmos coleta de dados no local.

A segunda ocupação é a Pilões - Invasão Pista Descendente (Via Anchieta), situada em terreno pertencente à Refinaria Presidente Bernardes. Existem pessoas que também criam animais nessa ocupação, mas como a atividade foi proibida pela Prefeitura e pela Vigilância Sanitária, alguns moradores tiveram que se desfazer dos animais, mantendo apenas as aves, embora tenhamos encontrado outras espécies. Para um entrevistado ${ }^{118}$, o dever da Prefeitura é cuidar da cidade e aplicar essa lei na cidade, e não proibir a atividade naquela região. Ele conta que mesmo com a proibição, tem um boi e dois cavalos de estimação, que mantém ali por perto. Somente seus gansos são criados em casa. $O$ resto do gado ele teve que vender.

Eu cheguei aqui a criar umas nove a dez vacas. E eu não tinha lugar para criar, eu criava assim com maior carinho, com a ração, no meu quintal. Que eu tenho um quintal grande ali atrás da Petrobrás... Aí, chegou numa situação que a prefeitura chegou em cima de mim e foi dizer assim: 'Olha, tem que se desfazer de tudo! Desfazer de tudo porque o negócio vai pegar' Aí eu fui e desfiz do meu gado. Mas as parideiras eu vendi para fora, levei lá para Pedro de Toledo. (Entrevistado pela autora, julho/2006)

Para o entrevistado não está claro a quem pertence a área que ele ocupa ou faz uso. Ele acha que é da Petrobrás, mas insiste em dizer que por ali ninguém é dono de nada. Essa situação permitia que ele tivesse um "lazer" criando suas vaquinhas ${ }^{119}$.

118 Sergipano, está em Cubatão há mais de 20 anos.

${ }^{119}$ No capítulo III faremos uma discussão sobre o significado de Lazer para essas pessoas. 


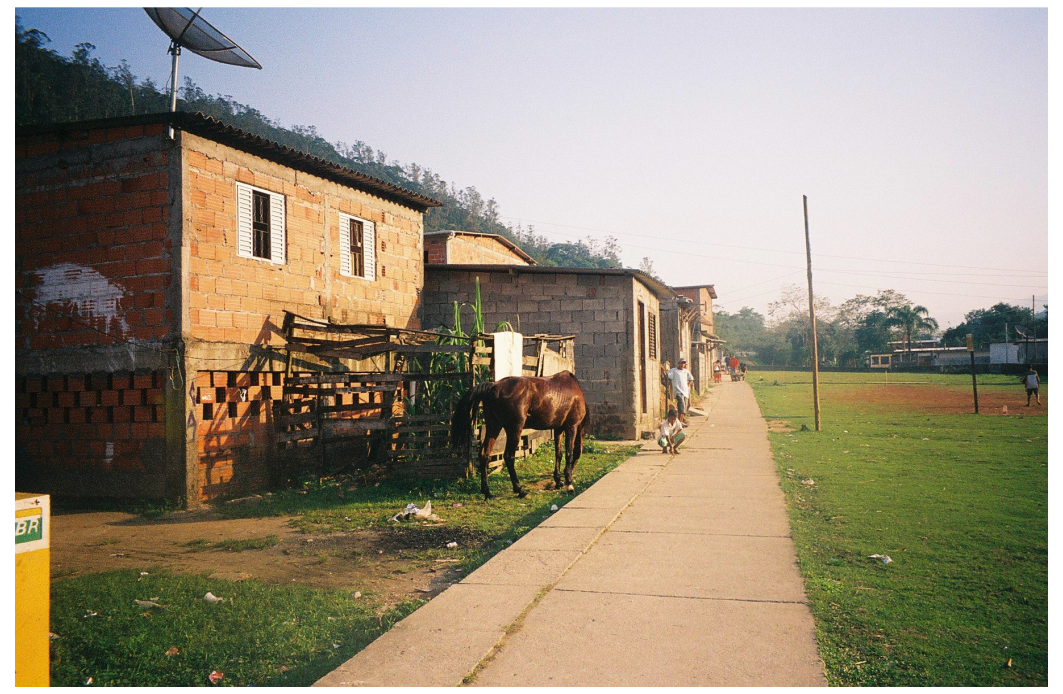

Figura 8: Foto da favela na entrada para os Pilões, cujo acesso se dá pela Rodovia Pedro Taques. Em primeiro plano observamos um marco da

Petrobrás. Um cavalo pasta próximo a casa, junto a uma pequena horta, e à direita fica um terreno aterrado que serve de pasto e área de lazer.

(Data:21/07/2006)

Os Pilões é uma área de muitos conflitos de terra. Um funcionário da prefeitura relatou, por exemplo, que há áreas inscritas no INCRA, e a Prefeitura não cobra IPTU para não haver bitributação. Porém, os moradores não pagam nenhum tipo de imposto. Poucos anos atrás, a Prefeitura restringiu o uso de uma parte da área para a proteção de manancial, então a população do local entrou com uma ação indenizatória contra a Prefeitura, alegando uso agropecuário e extrativista do local. Assim, o decreto foi revogado. Outras questões são levantadas e os conflitos estão postos.

Segundo relatório recente (2006) do Núcleo Itutinga-Pilões ${ }^{120}$ há 46 propriedades, mas como elas estão dentro do Parque, são consideradas como áreas de invasão. Esses números se referem ao total do Vale, pois a administração do Parque não nos forneceu o número exato das propriedades localizadas somente em terras cubatenses. No entanto, uma funcionária do Parque estimou existirem cerca de 20 sítios.

Uma funcionária do Parque diz que as ocupações são irregulares, e merecem uma fiscalização ostensiva com o intuito de "amenizar as estratégias de ocupação", e mesmo assim é difícil o "controle", acrescenta ela.

\footnotetext{
${ }^{120}$ Pertencente ao Parque Estadual da Serra do Mar.
} 
Essa situação se repete em outras áreas do Parque. A área ciliar do mesmo também foi ocupada. No processo de criação do Parque não houve um 'entendimento' com os antigos moradores (todos sitiantes), pois o Estado não paga benfeitorias - possivelmente entrará com reintegração de posse, ou com uma desapropriação indireta. (Funcionária do Parque, 2005).

A área pertencia ao chamado "Sítio dos Queirozes" e, hoje, soma cerca de 5 sítios com agricultura mais uns 15 sítios adentrando o Parque ${ }^{121}$. Segundo a entrevistada no Parque:

Os indivíduos que moram nos sítios se consideram da área rural; e Cubatão é uma cidade que abriga uma "situação rural", porém não é rural: é urbana, de mangue e de parque. (Entrevistada pela autora, 2005).

De certa forma, essa fala exemplifica bem o paradoxo vivido pelos moradores do local. A proximidade com a cidade de Cubatão destaca os Pilões como uma área de transição (nem campo, nem cidade). Em duas entrevistas foi utilizada a expressão "mato" para definir o Vale: "Ah, isso aqui é o mato". A palavra "mato" dentro desse contexto pode ser interpretada como o contrário da cidade, onde a natureza se faz mais presente, e a ocupação é diferente da que é encontrada na cidade, onde os usos são outros.

Embora destoe do resto da cidade (em sua forma), essa paisagem está ainda dentro da mesma, constituindo uma descontinuidade. A noção de campo supõe uma forma especial de caráter mais contínuo e mais afastado da cidade. E como a população de fato está em uma zona de reserva ecológica na Serra do Mar, a paisagem é de uma floresta fechada, o que na interpretação de muitos pode ser considerada um mato.

A relação com o local é percebida como oportunidade de vivenciar um pequeno isolamento, afastamento da cidade; a busca pelo campo, que ficou para trás (no passado de alguns). Nesse sentido, o Vale dos Pilões se mostra um refúgio, para muitos, uma área capaz de abrigar não só formas como também conteúdos rurais.

${ }^{121}$ A administração do Parque não nos revelou maiores detalhes sobre esses sítios. 
De modo geral, o paradoxo vivenciado por seus moradores é claro. Todos fazem uma separação entre aquele local e a "cidade". Quando perguntamos a uma entrevistada $^{122}$ sobre essa questão e sobre como ela se sentia morando ali, ela respondeu: "Eu gosto demais! Ora, mas ainda tem dia que eu vou para Cubatão, com trinta minuto eu não agüento! Que eu não bebo nem água lá, tenho que beber Coca Cola. Para matar minha sede".

A entrevistada mora num sítio na margem direita do Rio Cubatão, no fundo do sítio fica o rio, onde, segundo relatos, há muito peixe pequeno, mas o que mais se pesca é o camarão. Os moradores dos Pilões ainda enfrentam alguns problemas com a poluição e com a violência. A mesma entrevistada falou que, ao sair num sábado à noite, teve dezesseis patos roubados.

Se você vê a água do rio, faz gosto! Nós toma banho aqui, quando está limpinho assim. Porque tem vezes que tem as cachoeiras da serra, que tem as cachoeira lá de cima, que eles botam uma coisa feia branca, que diz que é uma fábrica de isopor que tem, que eu não sei onde é. Tem uma fábrica de isopor, eles que trabalham por aí devem saber... Tem vezes que a água está branquinha. Aí dá aquela coceira na gente. (Entrevistada pela autora, julho/2006)

No seu sítio há plantações de algumas frutas, verduras e legumes, mas sua maior produção é de bananas. Ela diz que não sai pra vender e que comercializa o produto em casa. Algumas pessoas oferecem peixe e camarão em troca das bananas.

Olha, nós planta mandioca, planta milho, feijão. Ah, e dá tudo! Quando está no tempo duro assim no frio, esse ano nós tivemos bastante coisa aqui. Agora está no tempo da jaca, nós estamos produzindo, os pés estão tudo cheio.

Nós vende tudo. Basta a gente ter necessidade, mesmo as banana aqui, olha, só tem essas daí madura, hoje eu já vendi tudo. Nós não sai para vender. E outra coisa, dá muito é camarão, peixinho pequeno (no rio Cubatão) só pego mais é de fora. O pessoal vem de fora e troca por banana aqui... (Entrevistada pela autora, julho/2006)

${ }^{122}$ A entrevistada é do Ceará e está em Cubatão há 22 anos. 
Observamos, nas fotos seguintes, o trajeto de alguns animais pelas estradas do Vale e a propriedade sobre a qual falamos acima:

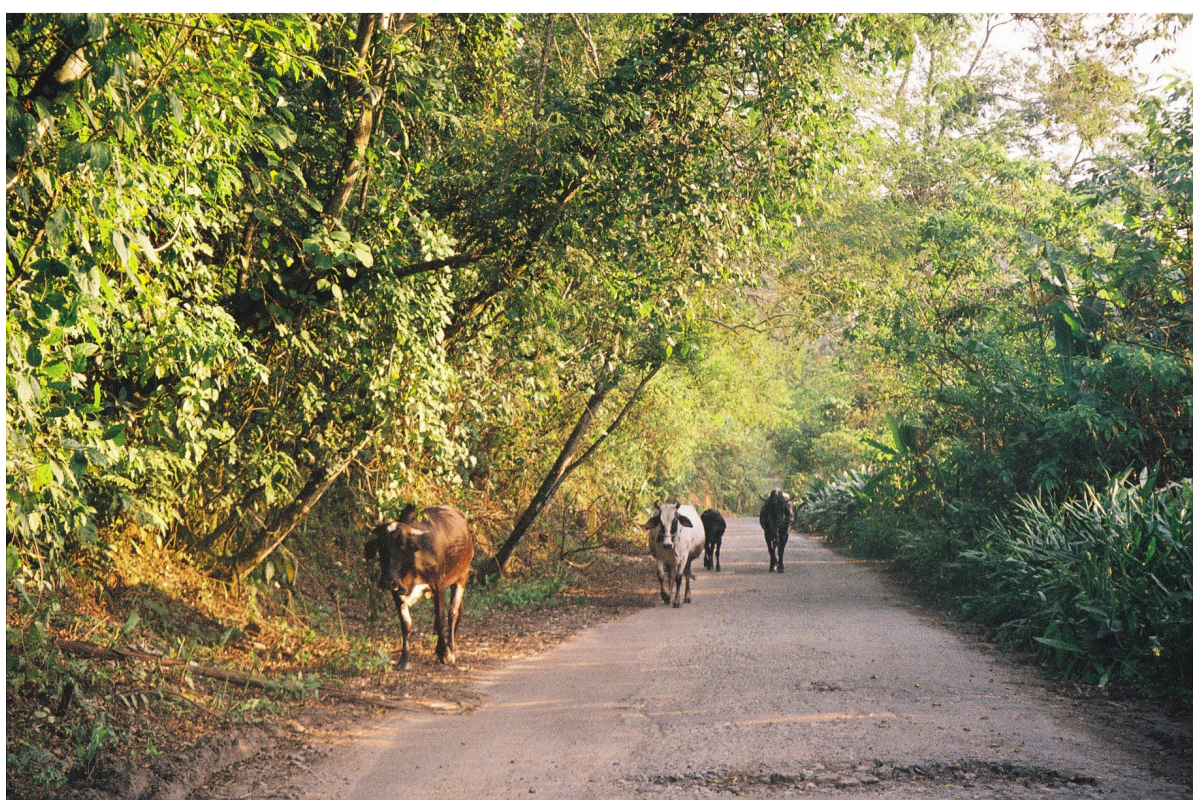

Figura 9: Animais na estrada dos Pilões (paralela à margem direita do rio). (Data:21/07/2006)

Fonte: Foto Vilma Aparecida da Silva

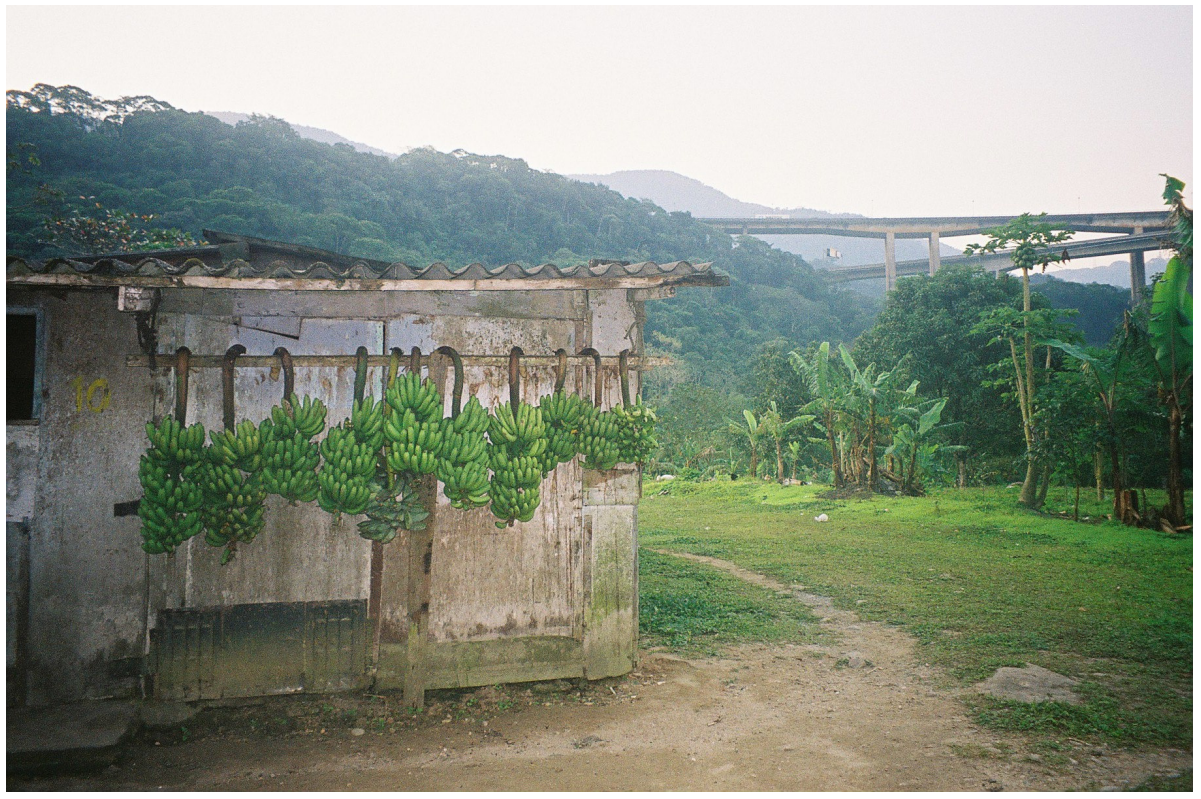

Figura 10: Foto de uma pequena propriedade nos Pilões. Podemos observar as bananas expostas para venda. Ao fundo, antes do morro, fica o rio Cubatão; e as "Rodovias Imigrantes" e "Nova Imigrantes" cruzando o Vale. (Data:21/07/2006) Fonte: Foto Vilma Aparecida da Silva 
Embora não tenha oficialmente uma área rural, os Pilões apresentam algumas características rurais. Os moradores da cidade enxergam grande parte dos Pilões como área rural, considerando os recursos naturais ali existentes, o tipo de habitat e a produção agropecuária encontrada no local. Ele é considerado um local de lazer da população, que para lá se dirige em busca de banhos de cachoeiras e de rio, e aproveitam as trilhas na mata.

Lá existem sítios, com casas $^{123}$ de padrão mais elevado do que encontramos na cidade, que estariam dentro no novo conceito de habitat discutido por Coelho (1999 apud VALE, 2004) e Seabra (2004), um tipo de segregação sócio-espacial, que reúne lazer, segurança e atributos do campo - uma forma rural sem o conteúdo agrário, onde as plantações frutíferas apresentam um outro significado.

Não há uma estrutura de serviços urbanos que atenda essa população, como mercados, transportes, hospitais, e escolas, entre outros (salvo as duas favelas que contam com pequeno bar). Seus moradores ficam, portanto, na dependência da cidade de Cubatão e inserida em sua dinâmica.

Poderíamos dizer que os Pilões é um espaço híbrido, que apresenta uma complementaridade entre modos de vida rurais e urbanos. Um produto do processo de urbanização da cidade, que ocupa os locais periféricos, ou seja, a expansão da cidade que se estabelece, mas que é, ao mesmo tempo, contida, ao menos temporariamente, pela existência do Parque e de propriedades particulares revelando também uma condição de "pousio social", típica de áreas periurbanas.

A grande maioria da população dos Pilões é assalariada, e se desloca todos os dias para o trabalho em outras áreas da cidade. A principal fonte de renda da maior parte dos moradores do Vale dos Pilões com certeza não provém das atividades rurais. No entanto, essas atividades não deixam de ser expressivas no contexto da região. Mesmo sem ser considerada pelo poder público uma área eminentemente rural, o uso rural se impõe. É um espaço diferenciado na configuração da cidade, possibilitando alguns arranjos sociais que atendem às necessidades da população, principalmente no que se refere a uma expressão cultural camponesa. De qualquer forma, o tipo de uso que se faz da área dos Pilões está em conflito com o uso

\footnotetext{
${ }^{123}$ Segundo relatos, a maioria das casas é de "doutores" e vereadores.
} 
determinado oficialmente. Nesse sentido, a apropriação da área por parte dos moradores revela uma urbanização crítica, que necessita de uma maior investigação.

Ao longo do trabalho de campo, foram aparecendo muitas ligações com os Pilões. Isso pode demonstrar o peso do bairro na análise proposta por este trabalho. Procuramos aproveitar todas as possibilidades com as quais nos defrontamos. Muitos de nossos entrevistados fizeram referência aos Pilões: conhecem produtores, fazem uso do local e mantém animais na área sob os cuidados de algum morador. De fato, existe uma certa conexão, ou com as pessoas e as atividades exercidas ali, ou com o próprio local, por apresentar condições estimuladoras de atividades agrícolas, mesmo sob controle de uma instituição do Estado que inibe e proíbe tais atividades.

Os Pilões aparecem, dessa forma, como um local privilegiado, onde a apropriação do espaço tem uma forma diferenciada, dando respaldo às necessidades e aos desejos. Em linhas gerais, os Pilões aparecem como um refúgio, um local onde as atividades agrícolas são razoavelmente toleradas pelo poder público, face aos conflitos criados em torno de algumas práticas agrícolas na cidade, como a criação de animais de grande, médio e pequeno porte. Além de revelar um espaço de miséria, onde a população desfavorecida se fixa, dada a explosão da cidade ${ }^{124}$, a área também evidencia um novo tipo de habitat, de indivíduos que buscam os recursos simbólicos do campo a partir da auto-segregação. Os Pilões, portanto, não se restringem apenas a uma área de ecossistema natural, mas encerra uma complexidade significativa dentro da realidade ampla onde se insere.

\subsection{Agricultura Urbana}

Conforme a FAO (Food Agriculture Organization), a agricultura urbana se refere às atividades de horticultura, pecuária, produção de forragens e leite, dentre outras. Essas atividades podem se desenvolver tanto dentro dos limites da cidade quanto nos seus arredores - isso caracterizaria respectivamente, a agricultura urbana e

\footnotetext{
${ }^{124}$ A população então passa a ocupar os espaços periféricos.
} 
periurbana. Pereira (2000) e Roese (2006) também classificam como agricultura urbana aquela que é realizada no entorno da cidade, ou seja, no espaço periurbano. De qualquer forma, esse tipo de agricultura pode ser tanto para consumo próprio, ou de caráter comunitário ou ainda uma produção que extrapole o consumo e se destine à venda, sendo realizada em vários espaços dentro da cidade.

A partir da definição acima, gostaríamos de destacar a agricultura urbana realizada na cidade de Cubatão, onde encontramos hortas na maioria de seus bairros.

Nosso estudo se iniciou com as hortas do Bairro Jardim 31 de Março, se estendendo para outros bairros, como Vila Padre Manoel da Nóbrega, Vila Nova, Vila São José, Jardim Costa e Silva, Jardim São Francisco ${ }^{125}$, Vila São Vicente, Caminho 2, Vila Natal, Conjunto Residencial Mário Covas, Conjunto, Conjunto Marechal Rondon, Parque Fernando Jorge, Jardim das Indústrias, Jardim Anchieta, Pilões, Areais, Vila Esperança e Sítio Capivari. Nesse movimento além de hortas encontramos também a criação de animais tanto de pequeno quanto de grande porte, principalmente a criação de cavalos (que, como as hortas, fazem parte da paisagem da cidade), além de algumas pequenas propriedades rurais - como é o caso do Sítio Capivari, Areais e Pilões. Embora tenhamos encontrado indícios de hortas em vários outros bairros, nosso estudo se concentrou apenas nos bairros acima citados.

Se compararmos a agricultura urbana com a tradicional, percebemos algumas diferenças. Na agricultura urbana, o espaço destinado ao cultivo é bem menor, é uma atividade que dificilmente pode receber uma dedicação exclusiva, não visa primeiramente à obtenção de lucros financeiros e apresenta uma diversidade de cultivos $^{126}$. Em Cubatão, a maioria das hortas situadas em locais públicos é mantida por aposentados. A disponibilidade da terra e a pré-disposição (espontaneidade) dos moradores locais foram elementos importantes no desenvolvimento desse tipo de atividade em Cubatão.

\footnotetext{
${ }^{125}$ Inclui Conjunto Residencial Afonso Schmidt e Gleba 3.

${ }^{126}$ Esse aspecto é interessante ser ressaltado nesse tipo de atividade, pois se assemelha à agricultura camponesa (que não utiliza uma lógica direcionada ao agronegócio ou à monocultura), justamente por priorizar a diversidade das culturas, dentro de uma tradição camponesa que busca sempre um padrão equilibrado em sua dieta com alguns produtos fundamentais.
} 
Roese destaca a relação entre a agricultura rural/tradicional e a agricultura urbana. Segundo Roese, a relação estaria no fato dessa última ser "praticada mais intensamente em regiões ou municípios que tenham tradição agrícola no meio rural". (2006, p. 01). Quanto a isso a história de Cubatão nos demonstra um passado agrícola, com o plantio extensivo da banana e outras culturas.

A agricultura tanto periurbana quanto urbana apresenta riscos e benefícios.

Entre os benefícios podemos citar: o acesso aos mercados de consumo; menor necessidade de acondicionar, armazenar e transportar os alimentos; acesso dos consumidores pobres aos alimentos por meios distintos do mercado; disponibilidades de recuperação e reutilização de rejeitos; geração de empregos e renda agrícola (no caso da horticultura, em função da grande diversidade de espécies que pode ser cultivada, pode-se obter produtos, emprego e renda durante todo o ano). Além de contribuir para a segurança alimentar. (PEREIRA, 2000, p. 03)

Com relação à saúde alimentar, Pereira (2000) destaca a importância da agricultura urbana para as camadas mais pobres. Isso parece bastante pertinente ao caso de Cubatão. As hortas ajudam na complementação da alimentação das famílias envolvidas diretamente com essas e também indiretamente, pois vizinhos, conhecidos, parentes e mesmo desconhecidos são beneficiados com seus produtos (verduras, legumes, frutas e plantas medicinais). Observamos uma relação de reciprocidade envolvendo as hortas, sobre a qual discutiremos posteriormente. Também encontramos pessoas que vendem parte de sua produção para a população local. No bairro Vila Nova, dois terrenos são ocupados com plantio de verduras, que são vendidas em carrinhos de mão pela cidade. Além das hortas em locais públicos, também encontramos algumas hortas em quintais de casas em vários bairros.

Sobre os riscos envolvidos nesse tipo de agricultura, destacamos o uso inadequado ou mesmo excessivo de insumos agrícolas, levando, através de lixiviação à contaminação de fontes de água potável, do solo e atmosférica. E, no caso de produção pecuária, podem surgir enfermidades zoonóticas; e no caso de utilização sem tratamento de dejetos dos animais pode trazer riscos à saúde pública. $O$ cuidado com a qualidade da água utilizada na irrigação da horticultura mostra-se 
fundamental para manter a qualidade dos alimentos (PEREIRA, 2000). Em decorrência de nossa opção de pesquisa não pudemos avaliar essas considerações. No que se refere à criação de animais, a Prefeitura e a Vigilância Sanitária têm realizado algumas intervenções, mas com relação às hortas não há ocorrências, segundo a Vigilância Sanitária.

Em Cubatão, as primeiras hortas ocupando longos trechos de terra remontam à década de 1980. Segundo um assessor técnico da Prefeitura, Manuel Ubirajara Pinheiro Machado, a Prefeitura do Município de Cubatão desenvolveu um "Projeto Piloto de Hortas Comunitárias" durante o governo do prefeito Ney Serra em parceria com o Governo do Estado de São Paulo, Centro das Indústrias do Estado de São Paulo (CIESP) ${ }^{127}$, Eletropaulo, CESP, Petrobrás e Sabesp em 1985. A Eletropaulo liberou uma área em baixo das torres de alta-tensão no bairro Vila Natal e forneceu técnicos para auxiliarem em relação aos cuidados necessários ao ocuparem aquela área. A prefeitura forneceu terra, mão-de-obra, insumos, instrumentos e sementes, além de cercar a área e ministrar cursos sobre agricultura urbana. O CIESP contribuiu com análises de terra e forneceu agrônomo, assim como a Petrobrás. $O$ governo do Estado forneceu material didático para a montagem de cursos e treinamento de pessoal e a Sabesp se comprometeu a fornecer a água gratuitamente. O projeto piloto foi aplicado na Vila Natal, e posteriormente no Jardim Costa e Silva e Jardim Anchieta (especificamente no Centro Social Urbano - CSU), estando abertos à população. Segundo o assessor, o intuito do projeto era fornecer alimentos para as classes mais carentes, e comercializar o excedente, dividindo a receita entre aqueles que trabalharam nas hortas. O Banco do Estado de São Paulo (Banespa) também chegou a fornecer uma verba para o programa e abriu uma linha de crédito para a compra de equipamentos para a manutenção do mesmo, conforme relato do assessor.

Segundo relatos de moradores do bairro Jardim 31 de Março, as hortas nesse bairro são anteriores à política governamental de incentivo a criação de hortas no município. Contudo, podemos afirmar que a criação das hortas se deu na primeira metade da década de 1980.

\footnotetext{
${ }^{127}$ Segundo o assessor.
} 
Há um tratamento diferenciado por parte dos órgãos públicos quanto aos terrenos ocupados pela agricultura urbana (PEREIRA, 2000), pois em terrenos não edificados existe um incentivo a seus proprietários, através de descontos nas contas de água e no imposto Territorial Urbano (IPTU) para que desenvolvam o cultivo de hortaliças, ou os cedam a terceiros interessados nesse tipo de cultivo. Desta forma evitam-se também o acúmulo de lixo e a proliferação de animais peçonhentos, insetos e ratos. Essa situação pode ser aplicada no caso das hortas ao longo da linha de trem (na faixa de servidão) no Jardim 31 de Março. Conforme o relato de um entrevistado, os moradores em frente à linha de trem começaram a ter problemas com lixo e mato que chegou a invadir a rua, tornando freqüente $o$ aparecimento de ratos e cobras nas residências. E a Prefeitura não tomou nenhuma iniciativa para resolver a questão. Foi quando, em 1983, ele ${ }^{128}$ e um vizinho combinaram de limpar parte do terreno (próximo às suas casas) e plantaram dois grandes canteiros com couve, cebolinha e salsinha. Há 23 anos ele mantém a sua horta nesse local. Outros moradores, na ocasião, também resolveram aderir à idéia; juntos resolveram procurar a Ferrovia Paulista S/A (FEPASA) (proprietária do terreno), com o objetivo de esclarecerem a situação. Os engenheiros da FEPASA consideraram uma boa solução para o local, já que a limpeza acarretaria despesas. Desde então, as hortas passaram a ser cultivadas. Ficou acertado entre os moradores que cada morador poderia ocupar uma faixa de terra (na frente de sua casa e ao longo da linha de trem) mais ou menos correspondente à largura de sua residência, comportando aproximadamente de cinco a sete canteiros, caso o morador tivesse interesse em manter uma horta. Houve casos em que algumas hortas ficaram com um terreno maior, devido ao desinteresse dos vizinhos. No entanto, com o desenvolvimento das mesmas, outras pessoas do bairro manifestaram interesse em ter hortas naquele local - o que levou à diminuição no tamanho de algumas hortas e à criação de novas.

\footnotetext{
${ }^{128}$ A esposa de um entrevistado conta que em um determinado dia resolveu fazer costela de boi com caldo de salsinha, mas não tinha salsinha em casa. Foi então que ela pensou na possibilidade de transformar o terreno tomado de mato em horta.
} 
Durante a implantação e manutenção do projeto piloto, a prefeitura passou a fornecer adubo, terra e sementes para as hortas do Jardim 31 de Março, e alambrado e mourão de cimento para cercar as hortas ao longo da linha (a prefeitura tentou arborizar o local plantando algumas árvores nas calçadas, entre as hortas e as ruas). Atualmente os responsáveis pelas hortas não recebem nenhum tipo de apoio para o plantio. A água utilizada é carregada com baldes (cedida por um morador próximo); os moradores que residem em frente de sua horta utilizam mangueira. Somente a horta da Rua General Osório possui um relógio de água próprio, pois a prefeitura concordou com sua instalação desde que o vizinho ao terreno assumisse a responsabilidade de pagar a conta; essa prática não foi mais aceita pela prefeitura, salvo nesse caso especificamente.

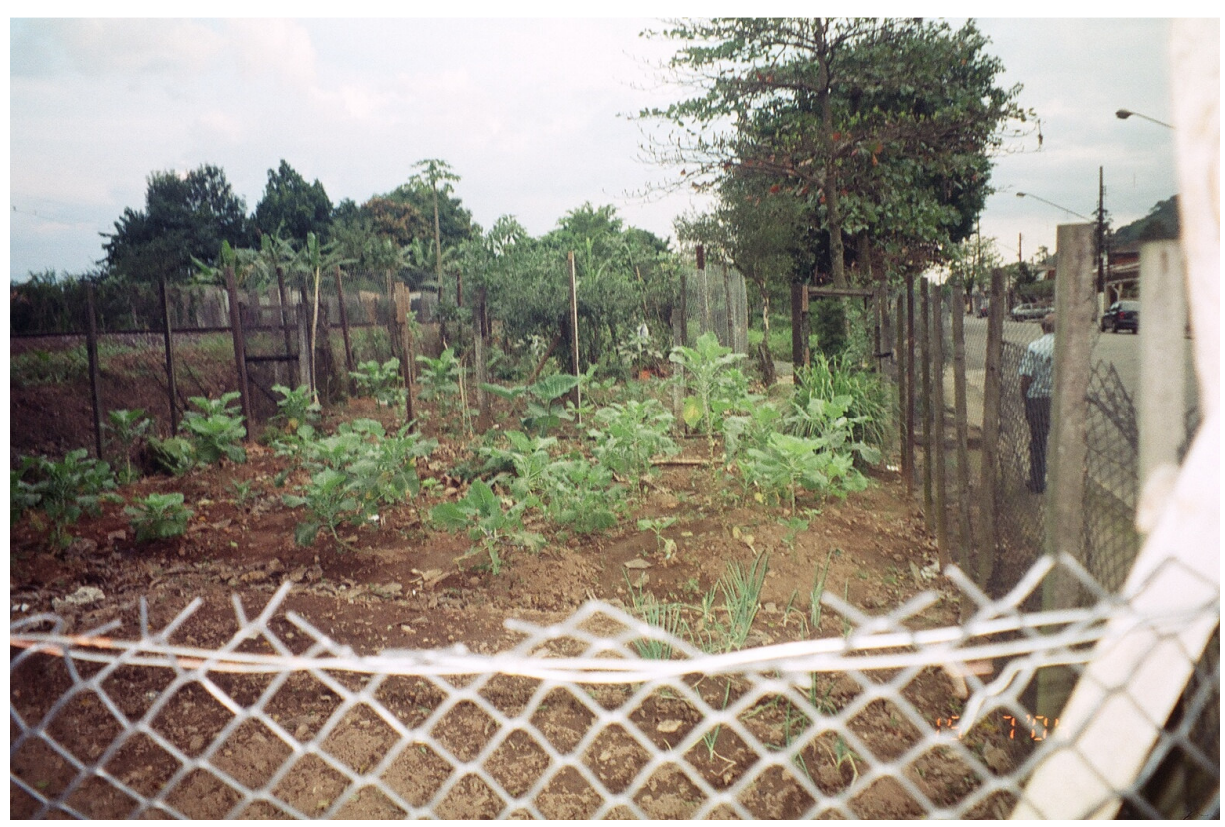

Figura 11: Essa horta fica (no Jardim 31 de Março) ao longo da linha de trem - que aparece à esquerda. Podemos observar nessa foto alguns canteiros de verduras. Em ambos os lados da linha existem hortas. (Data: 15/07/04)

Fonte: Foto Vilma Aparecida da Silva 


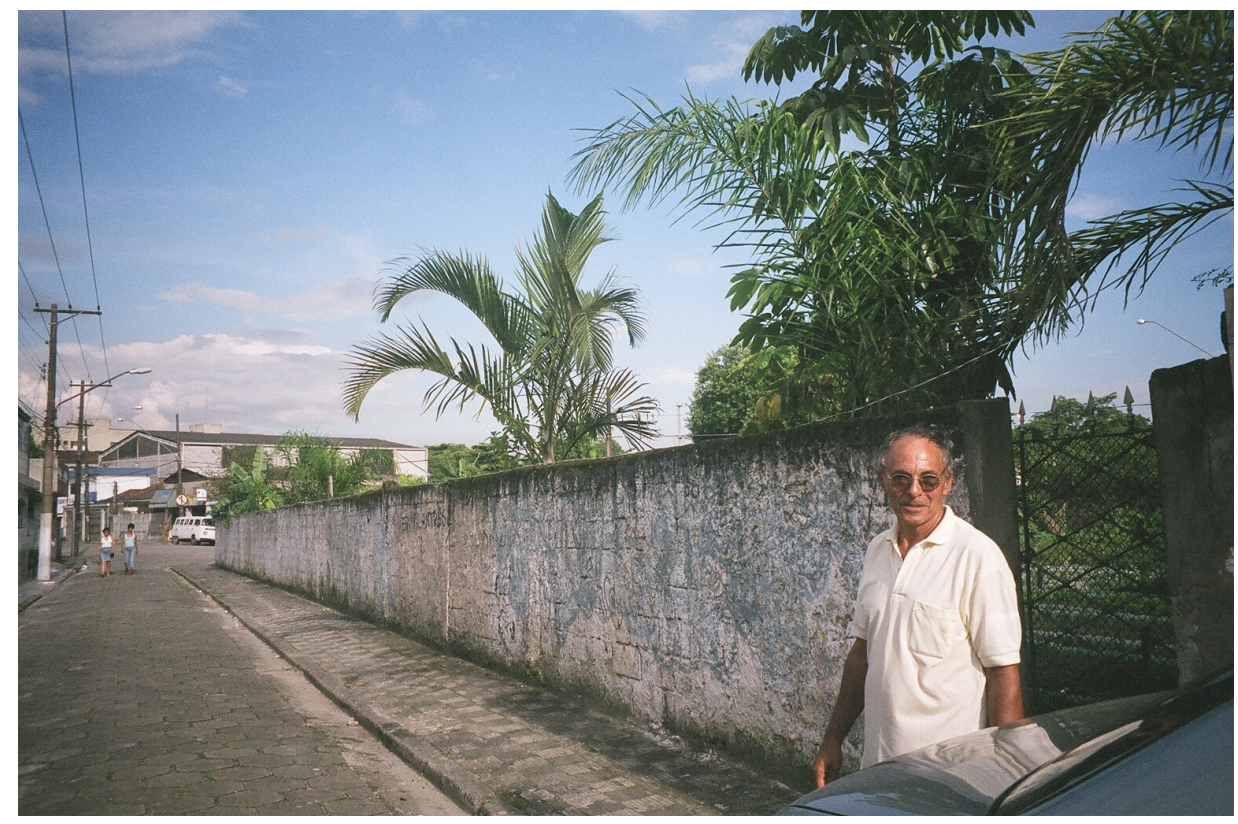

Figura 12: Horta localizada na Rua General Osório. A prefeitura planejou construir um posto de saúde no local, mas optou por outro terreno. Mesmo antes dessa decisão, o local já era ocupado com a horta. (Data: 16/01/04)

Fonte: Foto Vilma Aparecida da Silva

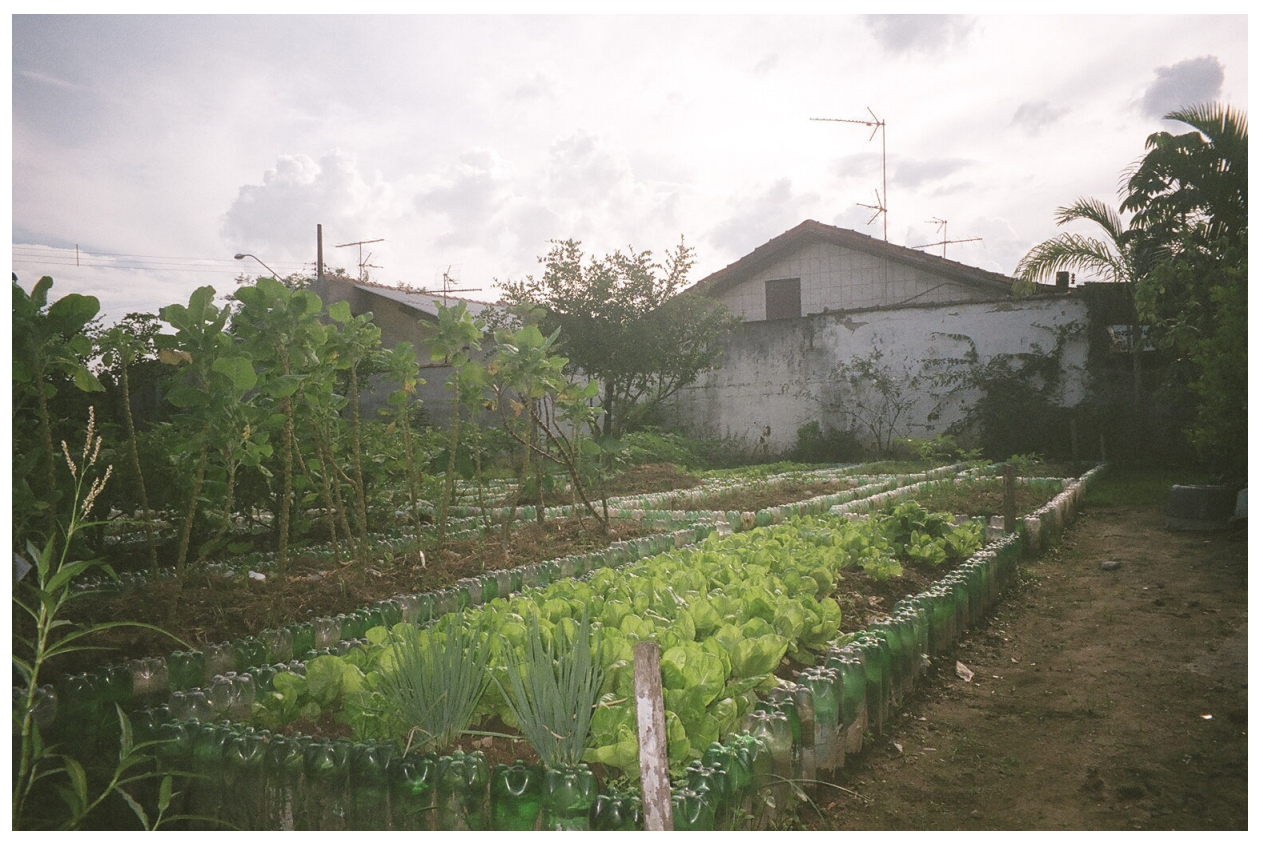

Figura 13: Parte do interior da horta localizada na Rua General Osório. Todos os canteiros nessa horta são cercados com garrafas plásticas cheias de água com o objetivo de preservar os canteiros. (Data: 16/01/04) Fonte: Foto Vilma Aparecida da Silva 
Nessa mesma época as pessoas também iniciaram a formação de hortas ao longo da lateral do canal, localizado na Avenida Henry Borden ${ }^{129}$ - perpendicular à linha de trem, de onde o canal torna-se aberto, indo até a Avenida Nove de Abril (principal avenida da cidade) - além de ocuparem também um terreno baldio próximo à linha de trem e ao canal. Uma entrevistada que atualmente mantém horta nesse terreno contou-nos como começou o plantio nesse local:

(...) É, como eu falei, o rapaz ali que mudou, aí ele que deu pra nóis porque eu prantava ali ó, na berada do canal... aí tinha uma fita ali até lá em cima, né, até na avenida, aí intão começou todo mundo a prantá, veio da linha e foi indo e aí intão eu arrumei um canteiro lá e prantei, e dava cada canteiro de alface que era uma beleza, né! Aí depois quando eles começaram a prantá grama, eu fiquei sem... aí começaram... naquela fita, começaram a prantá grama e ao mesmo tempo fez essas estalações, né, de eletricidade e diziam que num pudia mais aí todo mundo foi parando, né, aí o... o Wellington (morador de frente ao terreno) tinha aqui e pegou e me deu os dois cantero, tinha mudado também uma família que cuidava, aí ele me deu esse canteiro dessa outra família, aí comecei a cuidar, comecei a cuidar aqui e prantá minha coisinha. Aí depois ele também vendeu a casa e mudou pro Casqueiro, aí aumentou mais, né, aí o espaço aumentou mais... (Entrevistada pela autora, janeiro/2004)

\footnotetext{
${ }^{129}$ Localizada no Jardim 31 de março.
} 
Conforme o relato acima expõe, as hortas ao longo do canal não existem mais. A prefeitura decidiu acabar com as hortas, alegando alto risco devido à existência de torres de eletricidade no local. As hortas foram então substituídas por grama (onde podemos encontrar freqüentemente, como já comentado anteriormente, alguns cavalos pastando). Em terreno ao lado do canal construíram a Rodoviária da cidade.

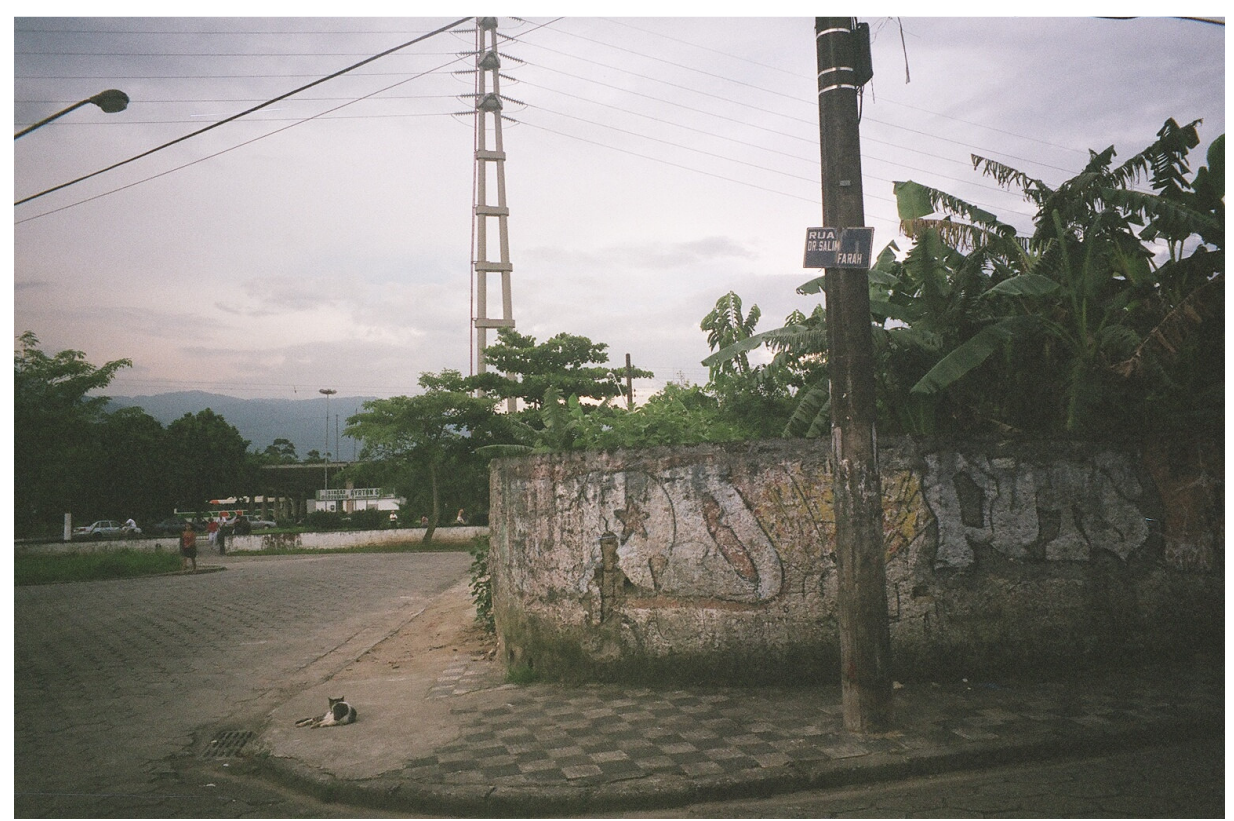

Figura 14: Em primeiro plano observamos a horta no terreno situado à Rua Dr. Salim Farah (JD 31 de março). Ao fundo o canal aparece cercado por um muro branco com uma ponte de pedestres que dá acesso à Rodoviária ao fundo. (Data: 16/01/04) Fonte: Foto Vilma Aparecida da Silva

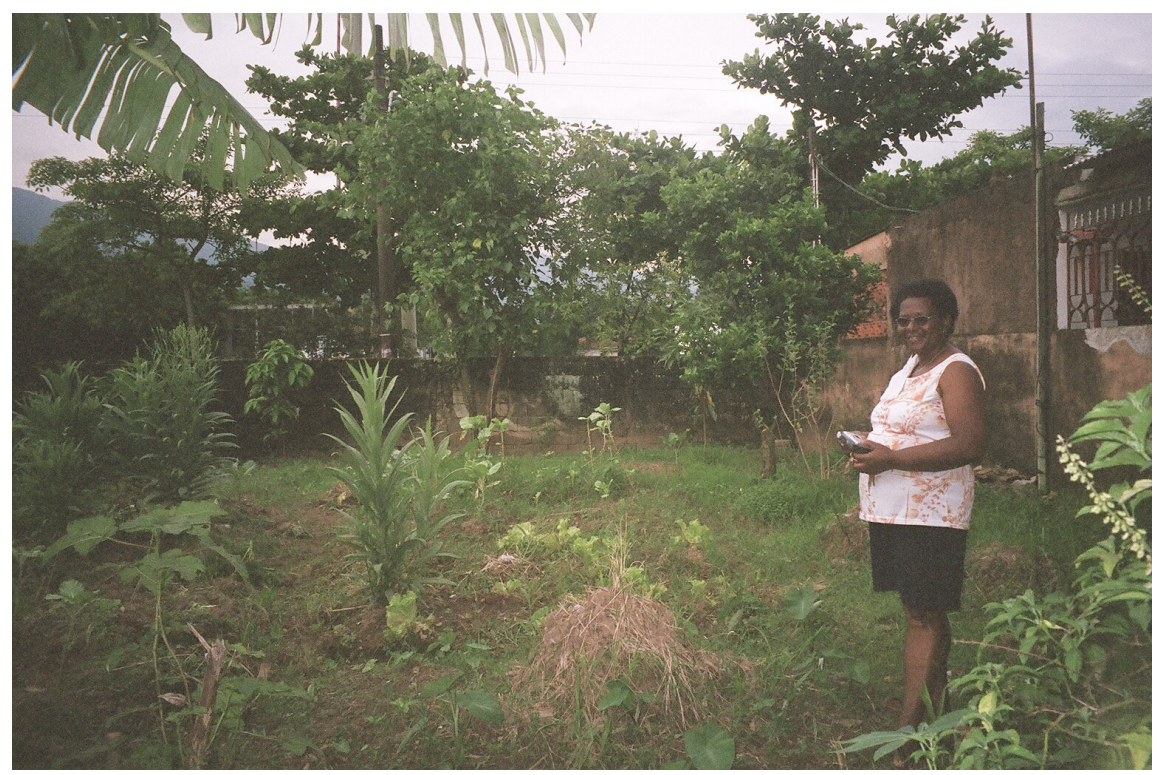

Figura 15: Nessa foto aparece parte da horta, sem muitas culturas, uma vez que a terra estava sendo preparada para um novo plantio. (Data: 16/01/04)

Fonte: Foto Vilma Aparecida da Silva 
A entrevistada não se sente muito confortável com a situação desse terreno, visto que a prefeitura construiu um muro ao redor dele e freqüentemente coloca "outdoors" no local. Ninguém sabe ao certo a quem pertence o terreno, somente que foi um dos espaços deixados pela Companhia de Habitação da Baixada Santista (COHAB) para a construção de áreas verdes, ou de lazer ou mesmo de serviços no bairro ${ }^{130}$. Sempre aparece alguém questionando a ocupação feita, alegando que o terreno será retomado.

A Vila Padre Manoel da Nóbrega se localiza entre um terreno da Petrobrás e a linha do trem no Jardim 31 de Março. São casas populares construídas inicialmente pela Cooperativa dos Metalúrgicos e posteriormente terminadas pela Caixa Econômica Federal. Na última fileira de casas dessa Vila existe um terreno que também foi ocupado com hortas, na mesma época em que essas foram iniciadas no Jardim 31 de Março. Um morador contou-nos que precisou aterrar uns nove a dez metros antes de fazer a horta. Chegou a produzir muitas verduras, consumidas por ele e sua família. Além das verduras, criava galinhas; os ovos ele consumia e distribuía (juntamente com as verduras) para os vizinhos. Como a produção era razoável, ele chegou até a vender para um minimercado do bairro, segundo ele, "não tinha o que fazer com a produção".

Nas hortas do Jardim 31 de Março e também do Conj. Padre Manoel da Nóbrega encontramos bancos, mesas e até cachorro. Embora estejam separadas da casa, se apresentam como o quintal dessas. À tarde podemos ver alguns moradores sentados embaixo de árvores, ou na lida com a terra. A maioria das hortas que se localizam próximo às residências têm essa característica de extensão da casa. A casa, portanto, não se restringe à área construída e delimitada, representada pela propriedade particular, mas se estende ao espaço da horta, privado, mas público, simultaneamente. Estabelece-se entre os vizinhos certo grau de solidariedade. São sementes partilhadas, o crescimento das plantas, as dificuldades no plantio, os insumos, as verduras e coisas da vida. Essa sociabilidade gerada por meio da horta

\footnotetext{
${ }^{130}$ Em um desses terrenos, inclusive foi construída uma unidade de serviços de saúde no bairro; um outro maior abriga uma Escola Estadual. Em outro construíram uma Sociedade de Melhoramentos; em outros, pequenas praças com imensos blocos de concreto e algumas árvores, um supermercado e num outro terreno existe uma grande horta.
} 
concede a esta o título de lazer e divertimento, muitas vezes, pois relembra "as coisas lá da roça", diz um entrevistado. O fato de se ter um quintal maior não impede que se tenha também uma horta. Encontramos pessoas que utilizam o espaço interno de seu quintal para plantar algum tipo de verdura ou folha de chá, além da manutenção da horta fora da casa. Dona Maria diz: "fui criada mexendo com terra, e eu gosto. O que me segura nessa casa é o quintal. Seu Antônio, sossegado com sua horta no terreno em frente à sua casa, acrescenta: "Aqui e roça é quase a mesma coisa. Vê isso aqui (aponta para as hortas)... parece cidade?! A gente aqui se dá bem, tem muita amizade...". A grande maioria dos entrevistados demonstrou vontade de ter um sítio, porém, as dificuldades financeiras e o trabalho (árduo) necessário para mantê-lo são fatores de impedimento. Aqueles que dispõe de maiores recursos conseguem comprar terras em municípios vizinhos, principalmente em São Vicente e em Peruíbe ${ }^{131}$. Muitos reclamam que não agüentariam mais trabalhar na roça, mas desejam estar nela. Um fato interessante que nos chamou atenção foi que um entrevistado se refere à horta como "roça".

A horta se apresenta então como elemento que compõe o espaço da casa, numa relação de complementaridade. Sobre a idéia de quintal, Lima (2003, p. 112) esclarece: "O quintal também pode ser percebido num outro sentido... permite que se mantenha uma espécie de vínculo com a terra, sentir o cheiro e o gosto da terra; é, quando retornam à terra que representa a realização de um desejo".

${ }^{131}$ Esse fato merece também uma atenção, mas diante de questões de tempo e delimitação da área de estudo, ficamos impossibilitados de realizar uma análise sobre o assunto. 
Embora faça parte, de certa forma da casa, a horta se localiza no espaço da rua (externa a casa) - aparecendo ora distante, ora próxima - numa sociabilidade ambígüa. Nos bairros onde encontramos hortas, a rua aparece como mais próxima (e apropriada no sentido do uso) do que distante. O seu uso comporta hábitos, e costumes que produzem singularidades espaciais e evocam práticas rurais trazidas de uma experiência anterior e contextualizadas e resignificadas no universo urbano. São especificidades de bairros periféricos que, de modo geral, expressam a dinâmica da cidade de Cubatão. A ocupação desses espaços nos remete ao conceito de apropriação pelo uso (fundado no costume), onde o valor de uso se sobrepõe ao valor de troca, em certo sentido.

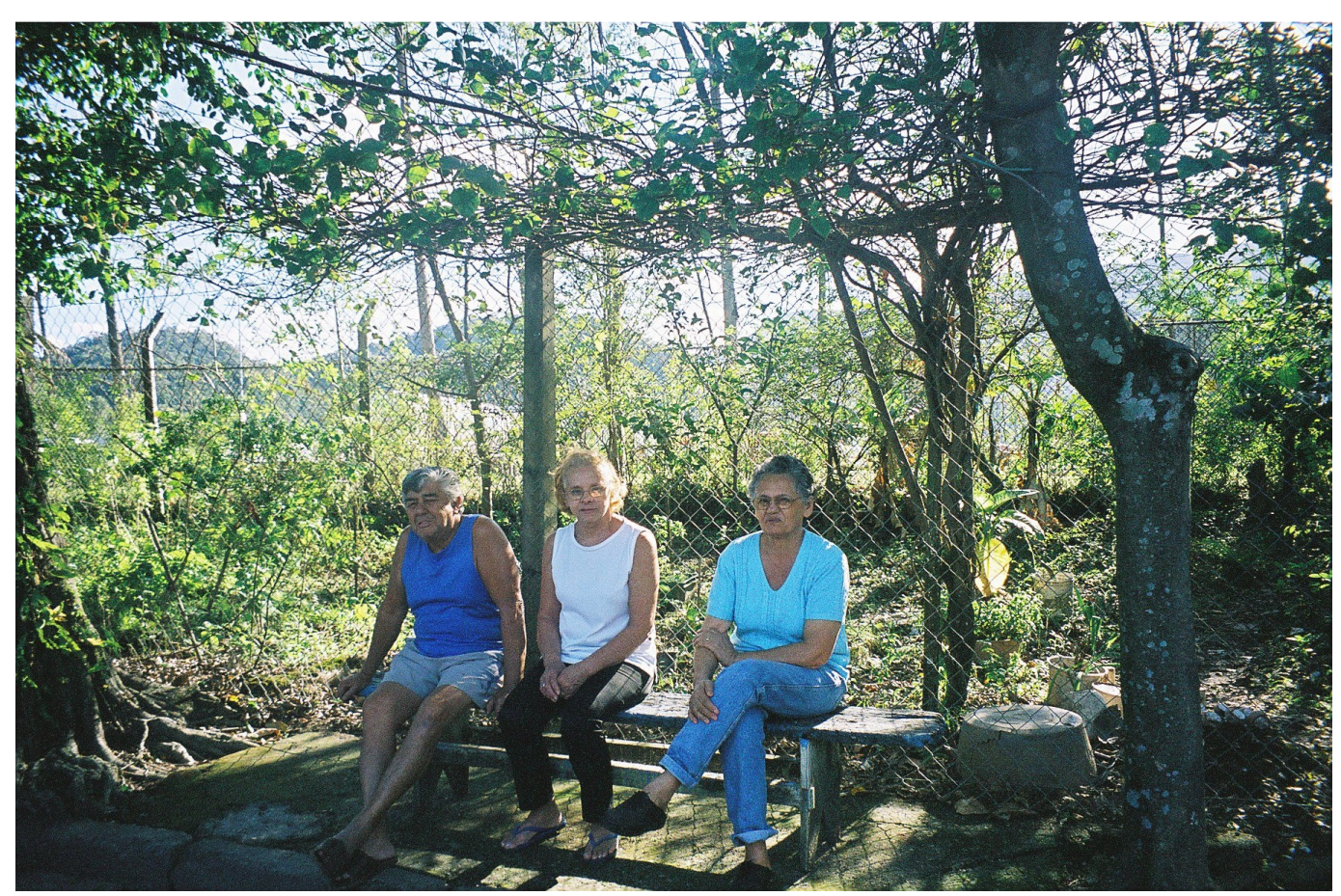

Figura 16: Moradores conversam à sombra de uma árvore no final de tarde em frente a uma horta na Vila Padre Manoel da Nóbrega. Ao fundo um terreno pertencente à Petrobrás, com algumas instalações da Refinaria. (Data: 11/08/05)

Fonte: Foto Vilma Aparecida da Silva

Mesmo antes da implantação do projeto de hortas comunitárias pela Prefeitura já haviam sido criadas as hortas do Jardim 31 de Março e da Vila Padre Manoel da Nóbrega, conforme relatamos. Segundo depoimento de um morador ${ }^{132}$ do bairro Vila

\footnotetext{
${ }^{132}$ Esse entrevistado diz que foi o primeiro a se cadastrar no projeto. Tanto é que sua horta é a primeira da gleba.
} 
$\underline{\text { Natal }}^{133}$, ele já tinha iniciado um pequeno plantio de sua "roça", mediante autorização de um membro da Sociedade de Melhoramentos do bairro, quando foi abordado por um funcionário da Eletropaulo dizendo que iriam "urbanizar" a área fazendo hortas comunitárias. O lixo acumulado no local era algo também que incomodava o entrevistado, relata. Cultivar seria então uma forma de organizar o espaço, urbanizar, possibilita a apropriação. A idéia de um espaço que comporte elementos tanto rurais, quanto urbanos e naturais formam o conceito do habitar. $A$ necessidade de conciliar esses elementos no urbano é uma constante nos depoimentos obtidos.

O primeiro fundador fui eu. Eu estava fazendo a roça aqui, então o engenheiro aí da rede, aí estava um dia lá fotografando lá aí eu fui coloquei aquele... Aquela proteção ali da rodagem e veio aqui procurou saber se eu tinha autorização de fazer roça. Eu peguei disse: Tinha. Perguntou, 'quem foi?' Eu disse foi o Carlinho ali da Sociedade Melhoramento. Ele chegou, foi lá, conversou com Carlinho e depois aí Carlinho pegou e disse 'Oh, eu autorizei'. Aí depois foi a turma tudo fazendo roça também. Aí eles cadastrou as roças tudinho e as metragens dos terrenos aí, tudo direitinho. Porque na época que eu fiz a roça nós não era cadastrado ainda. Eu já plantava esse alface, couve, mostarda e pé de mandioca, essas coisa que eu plantava aí.

Mas, depois teve reunião, cadastrou nós tudo direitinho... é... a metragem do terreno cada qual toma conta, e é para manter isso aí limpo porque isso aí de primeiro, quando eu tentei fazer roça aí, isso aí o povo jogava lata de lixo aí nos terrenos, às vezes era cachorro morto jogava aí, era aquele mal cheiro... Porque naquela época era ruim, era tripa de peixe, era tudo quanto era coisa aí.

Aí explicou a nós o que é que não podia plantar aí, o que é que podia plantar, né? Os minutos que podia ficar embaixo do cabo de força e assim por diante. Conversou tudo com nós, fez um bocado de

\footnotetext{
${ }^{133}$ Vila Natal foi onde foi implantado o projeto piloto de hortas comunitárias em Cubatão. Por volta de 1974, começaram a se instalar nessa área as primeiras famílias. Começou a se formar com a transferência de 350 moradores da favela Vila Esperança, parte das famílias vítimas do incêndio da Vila Socó (1984) e alguns moradores de áreas de risco do Morro do Marzagão. Fonte: <http://www.novomilenio.inf.br/cubatao/> Acesso: maio de 2006 e Coordenadoria do Desenvolvimento econômico de Cubatão.
} 
reunião, deu um papel para nós sobre as roças, disse que ia trazer um engenheiro agrônomo para ensinar nós como plantava também e assim por diante. (Entrevistado pela autora, agosto/2005)

$\mathrm{Na}$ Vila Natal encontramos 14 hortas com tamanhos variados, com cercas de vários materiais, sendo a maior parte cercada com madeiras. Todas apresentam grande variedade de verduras, alguns legumes, pés de frutas e plantas medicinais. A grande maioria das pessoas que mantêm as hortas nesse local são aposentados ou esposas de aposentados, ou ambos.

Ao longo da linha de trem (MRS Logística - que passa pelo Jardim 31 de março) encontramos a Vila Natal (com aproximadamente 5 pequenas hortas no trecho da linha) e em seguida a Vila Esperança ${ }^{134}$ e o Vale Verde (um pouco mais afastado), em direção à divisa com o município de São Vicente. Tanto a Vila Natal quanto a Vila Esperança se desenvolveram paralelamente à citada linha de trem adentrando a área de mangue. No final da Vila Esperança, na altura da Rodovia Imigrantes, existe uma pequena plantação de bananas e também algumas hortas. Segundo Dona Nina, moradora local que mantém horta, já há algum tempo os moradores vêm ocupando a área da parte de cima da linha de trem com hortas. Porém, começaram a roubar as verduras, sendo preciso cercar as hortas - pois eram abertas. A horta de Dona Nina está justaposta à linha de trem.

\footnotetext{
${ }^{134}$ A área da Vila Esperança inclui o Morro do Índio, Sítio Novo, Ilha Bela e uma ocupação além da Rodovia dos Imigrantes. Ela é definida como uma área de invasão e teve sua origem na década de 1970 com a construção da Rodovia dos Imigrantes. Conta com aproximadamente 6.000 moradias (em 2006). Fonte: Coordenadoria do Desenvolvimento Econômico de Cubatão e <http://www.novomilenio.inf.br/cubatao/> Acesso: maio de 2006. .
} 


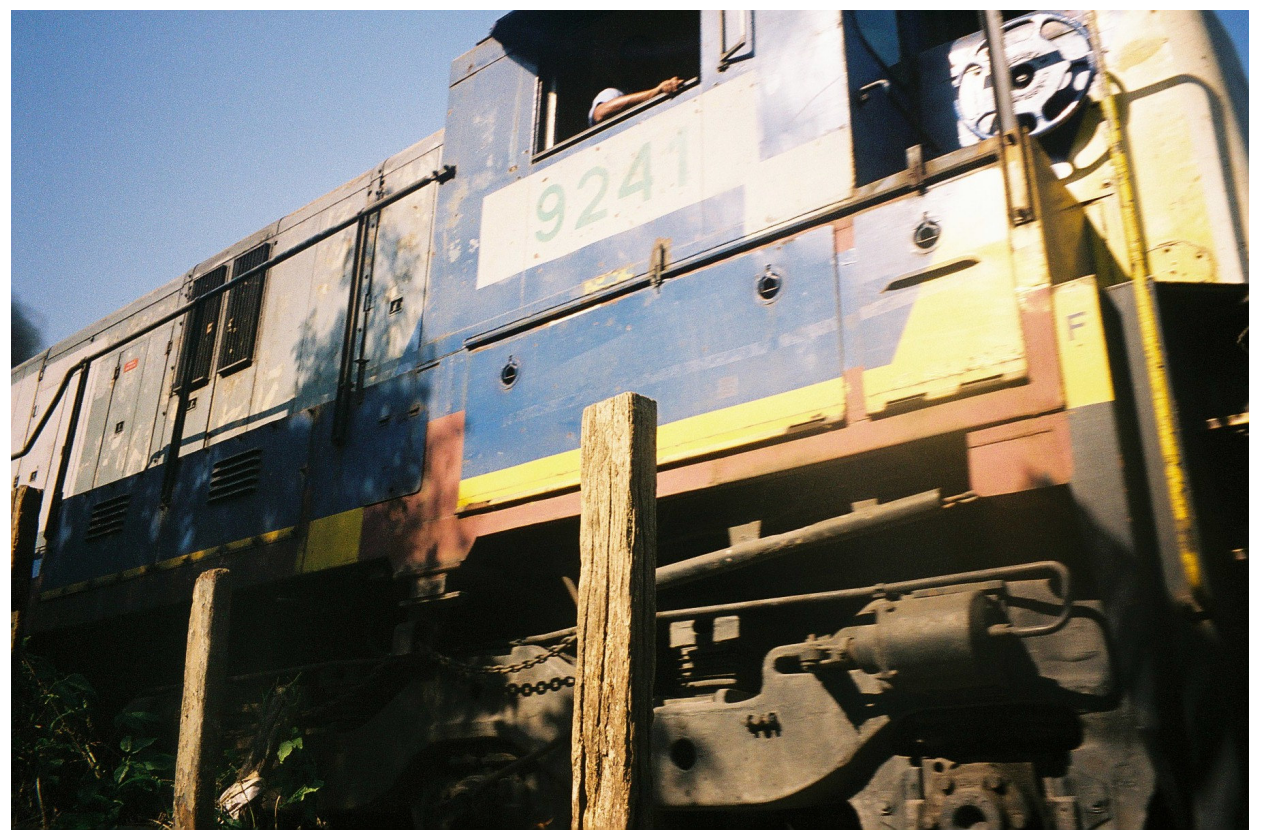

Figura 17: A foto acima observamos as estacas colocadas para a construção da cerca da horta de Dona Nina e Roselina e o trem passando... (Data: 28/06/06)

Fonte: Foto Vilma Aparecida da Silva

Muitas hortas em Cubatão são cuidadas por mais de uma pessoa, como é o caso da horta de Dona Nina e Dona Roselina. A partilha do uso da terra, do trabalho na terra e de seus frutos é muito comum. No caso de animais uma prática semelhante acontece: muitos criam "à meia ${ }^{135 "}$ (ou meação).

A ferrovia não autoriza o uso da área que pertence a mesma, a não ser para o plantio de hortas, chegando até a limpar a área com mais freqüência.

${ }^{135}$ É um tipo de organização da produção. Essa expressão significa metade, ou seja, entre duas pessoas que se dispõem a plantar ou a criar um animal fica acordado entre ambas que o produto final será dividido igualmente entre as partes. Existem várias combinações. No caso de animais, por exemplo, um entrevistado conta que recebeu uma porca (prenhe) de um amigo para criá-la "à meia". $\mathrm{O}$ que aconteceu nesse caso foi que quem recebeu a porca teve o trabalho e o custo (às vezes o trabalho e o custo também é dividido) de criá-la; mas, como ela teve 12 crias, o criador ficou com seis delas, depois quando decidiu matar a porca para comê-la, também cedeu a metade para o amigo de quem recebeu a porca. 


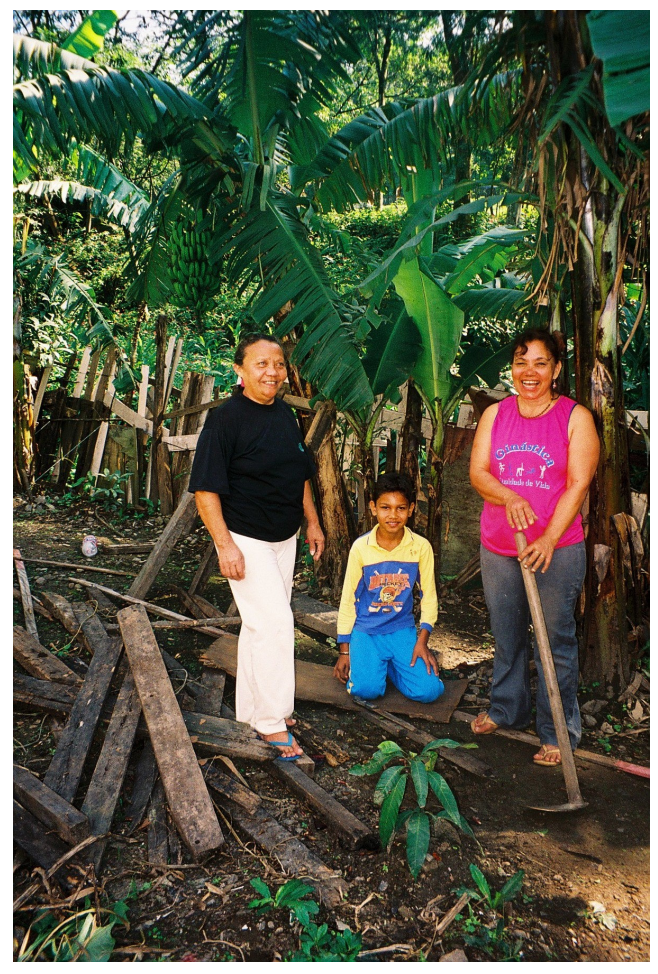

Figura 18: Na foto (à esquerda) Dona Nina, seu filho Cléber e Dona Roselina preparam a cerca de sua horta. (Data: 28/06/06). Fonte: Foto Vilma Aparecida da Silva
É, a ferrovia sempre limpa, sabe? Porque não pode deixar bagunça e não pode fazer a cerca muito perto da linha, né? É perigoso. Aí depois que a gente faz a cerca, a gente limpa tudo, sabe? Tira-se essa bagunça, deixa tudo limpinho. Aí fui plantando, assim, a ferrovia não incomodou ninguém, a gente foi fazendo, eles foi deixando... Porque por aqui, daqui até lá, onde você for aí, pode você ir olhando que tem bastante horta. (Entrevistada pela autora, agosto/2006)

Aí um dia eu vim, veio eu e o tio dele, né? Chegamos aqui aí eu disse "Vamos limpar ali para a gente plantar, né?" Aí ele limpou para mim, tudinho, que eu sozinha não conseguia e eu fiquei plantando aí, plantei alface, plantei coentro, plantei cheiro verde... (Entrevistada pela autora, agosto/2006)

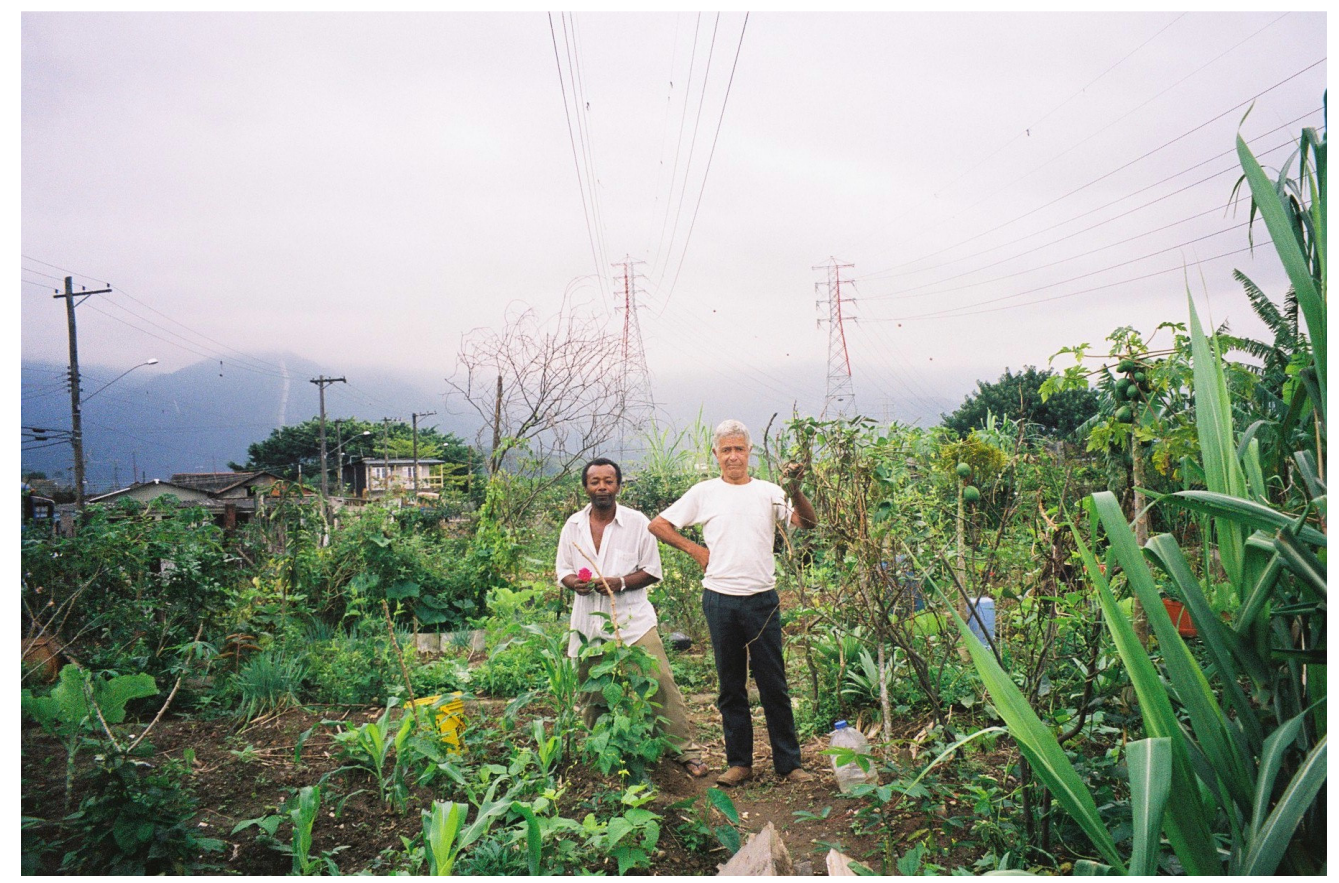

Figura 19: Essa foto mostra uma das hortas da Vila Natal - cuja existência é anterior ao projeto piloto de hortas comunitárias. Em primeiro plano vemos S. Zuza e S. Cícero. No meio da horta observamos alguns vasilhames utilizados na captação de água da chuva e também no transporte da água para a irrigação da horta e ao fundo as torres de energia e a Serra do Mar. (Data: 26/08/05)

Fonte: Foto Vilma Aparecida da Silva 


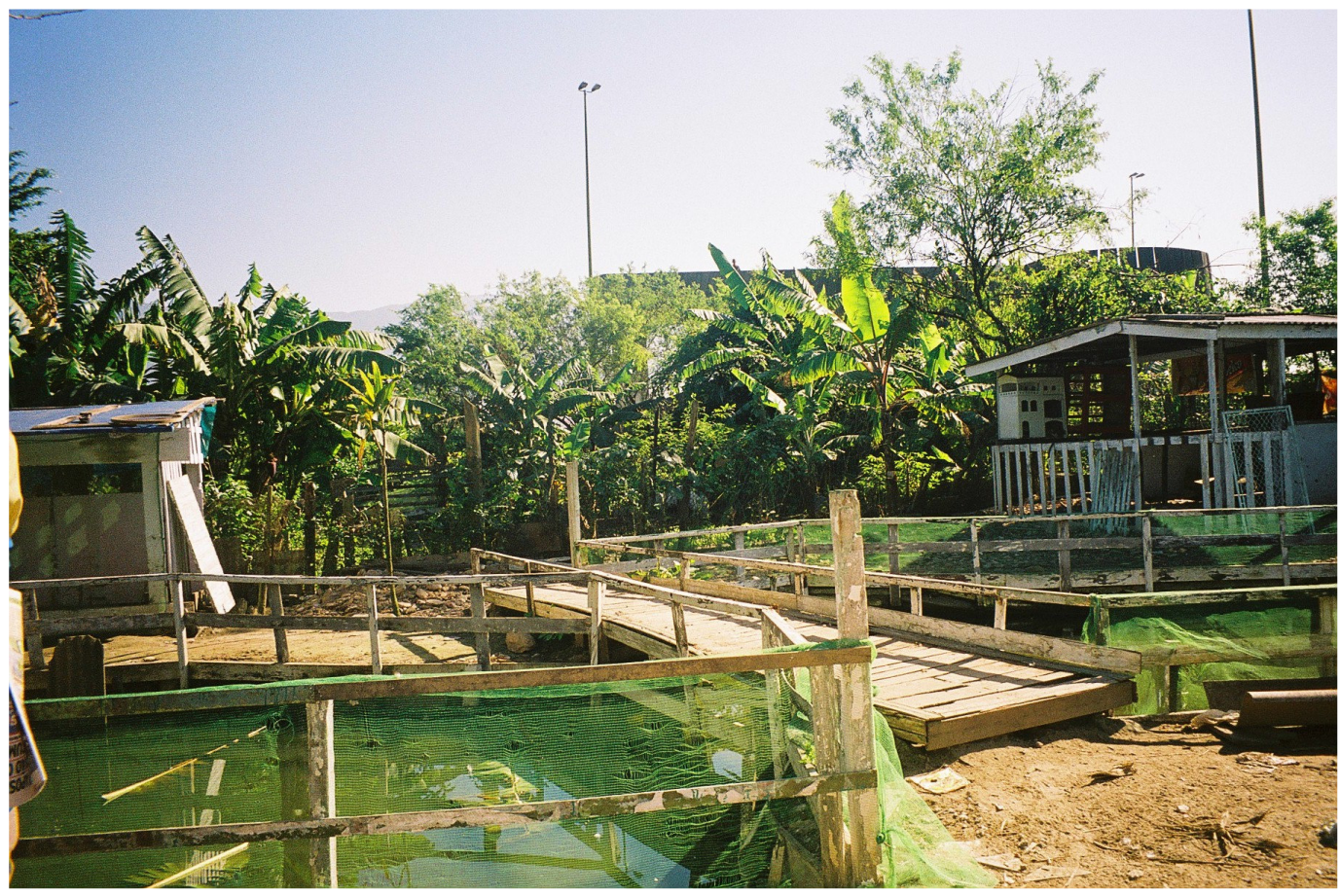

Figura 20: Em primeiro plano nesta horta do Caminho 2 podemos ver um pequeno lago onde são criados peixes. Em seguida observamos algumas estruturas que acomodam os víveres. Ao fundo fica a área de plantio, paralela à Rodovia Anchieta. (Data: 05/08/05)

Fonte: Foto Vilma Aparecida da Silva

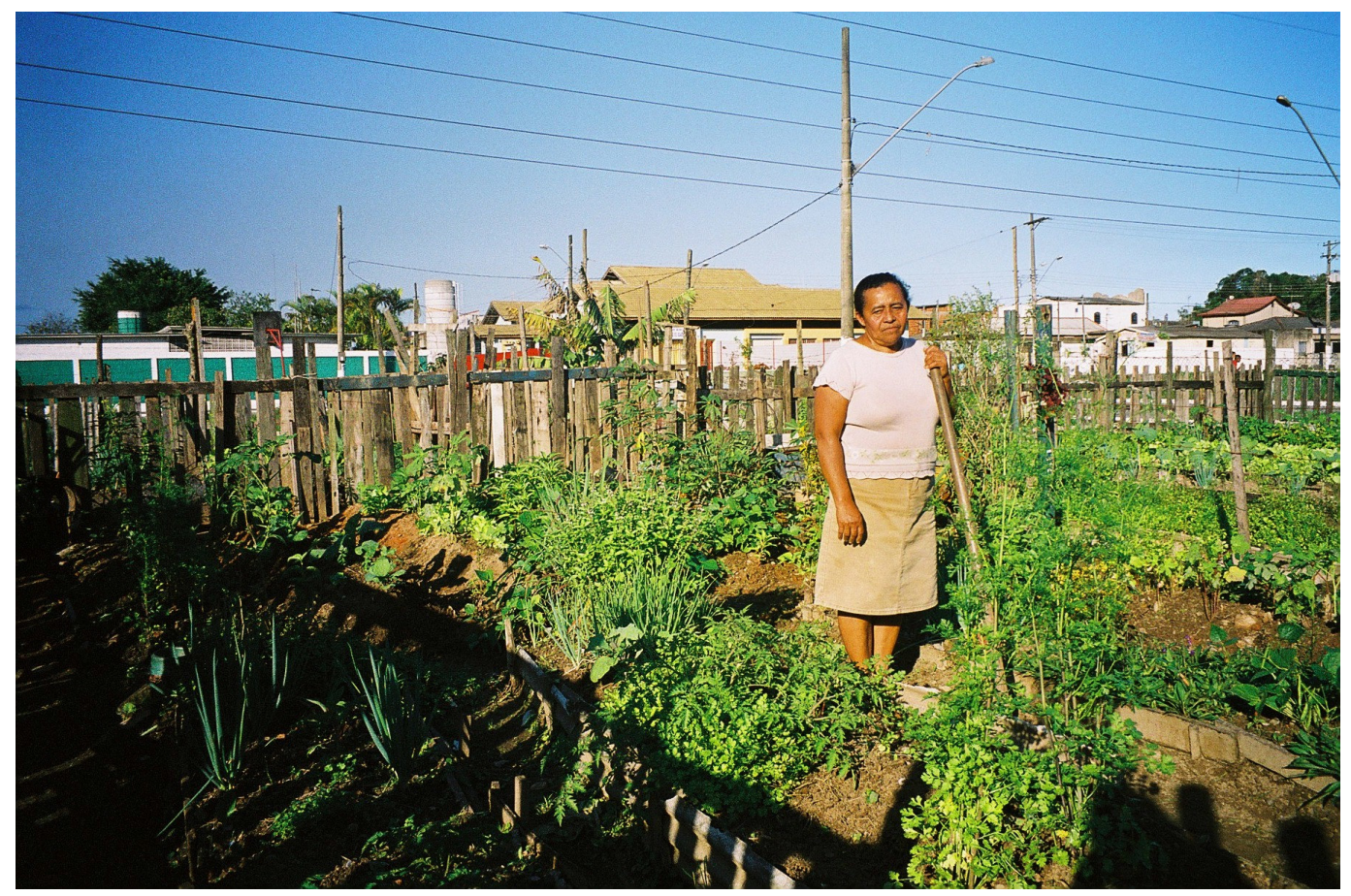

Figura 21: Dona Laudicena em sua horta na Vila Natal. Ao fundo observamos uma Escola de Educação Infantil e algumas casas do bairro Caminho 2. (Data: 11/08/05)

Fonte: Foto Vilma Aparecida da Silva 
As hortas do bairro Caminho $2{ }^{136}$ próximo à Vila Natal surgiram logo após a implantação do projeto piloto - no final da década de 1980. S. Edgar relata que onde atualmente as pessoas mantêm as hortas era cheio de lixo. Nas hortas encontramos além de verduras e legumes muitas árvores frutíferas e aves. Existe um pequeno córrego paralelo à pista descendente da Rodovia Anchieta. Os responsáveis pelas hortas aproveitam o córrego para a irrigação das mesmas e para o cultivo de peixes ${ }^{137}$ (alimentados com farelo - ração) e criação de patos e gansos. Em geral, as hortas não têm tamanho determinado, variando conforme a disponibilidade dos terrenos. Geralmente não são grandes, ocupam uma faixa longa de terra, que abriga várias hortas, e apresentam uma média de dez canteiros, aproximadamente. As cercas foram construídas pelos próprios mantenedores das hortas, construídas com material variado (tela, arame, madeira, ferro etc). S. Eliésio comentou que a terra é boa, sempre produz o que se planta, menos a manga - que segundo ele, "dá flor, mas não dá fruto".

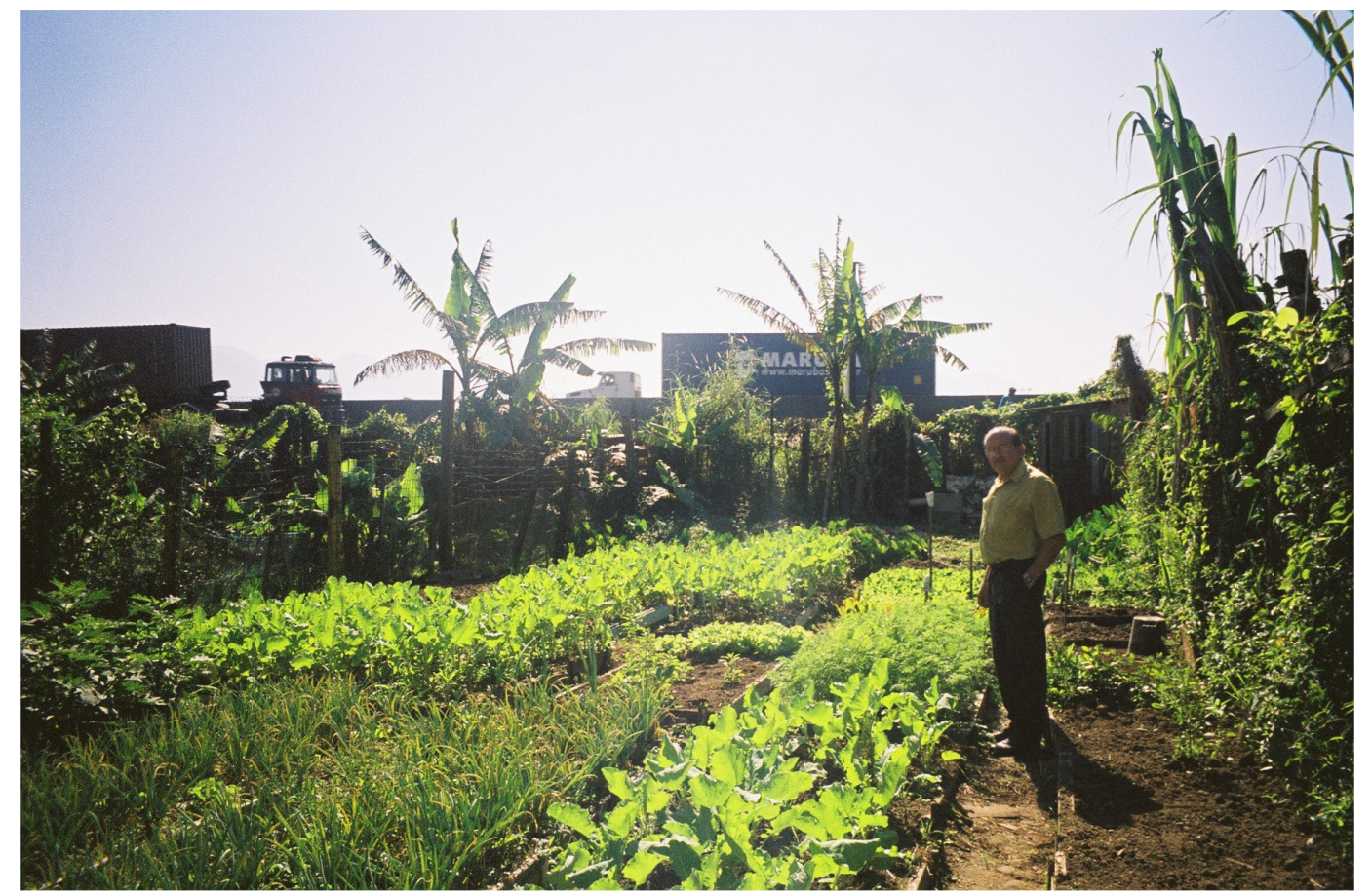

Figura 22: S. Sinésio mantém essa horta às margens da Rodovia Anchieta (pista descendente) no bairro Caminho 2. No fundo da horta (à direita) ele construiu um pequeno cômodo para guardar insumos e ferramentas utilizados na horta. Ao fundo podemos ver o trânsito de caminhões na Rodovia. (Data: 05/08/05) Fonte: Foto Vilma Aparecida da Silva

${ }^{136}$ Loteamento criado em 1987 abrigando as famílias que residiram no Curtume, em área da Dersa. Nesse loteamento residem aproximadamente 12.000 pessoas em 261 lotes. Fica próximo ao Parque 
No último lote do Conjunto Habitacional Governador Mário Covas, ${ }^{138}$ concluído em setembro de 2002, existia uma faixa de terra onde instalaram alguns brinquedos públicos. Atualmente a área foi transformada pelos moradores em hortas.

O Centro Social Urbano (CSU) localizado no bairro Jardim Costa e Silva fez parte do projeto piloto de hortas comunitárias na década de 1980. Neste local a horta é mantida num terreno amplo e murado, sendo cuidada por pessoas tanto do próprio bairro onde o CSU se localiza quanto de outros, como é o caso de S. Antônio (aposentado), morador do bairro da Vila Nova. Ele se desloca todos os dias até a horta no CSU para cuidar de 13 canteiros grandes, onde planta alface, cebolinha, couve, almeirão, batata-doce, entre outras coisas. As pontas de cada canteiro são destinadas para o plantio de ervas medicinais, pois é necessário que se tenha esse tipo de plantio, diz o entrevistado. Dentro da horta existe um pequeno cômodo para guardar ferramentas e insumos. Além de legumes e verduras existem alguns pés de frutas, como banana, acerola e mamão.

De acordo com a definição de agricultura urbana, os terrenos "vazios" tornam-se muitas vezes passíveis de terem esse uso (hortas); são terrenos públicos ou privados não edificados, onde se desenvolvem principalmente as hortaliças. No caso de Cubatão isso pode ser observado em faixas de servidão de ferrovias e rodovias. Em faixas de ferrovia encontramos as hortas do Jardim 31 de Março, algumas na Vila Natal, na Vila Esperança, no centro da cidade e no Jardim São Francisco. Ao longo da Rodovia Via Anchieta estão as hortas da Vila São José, Vila Natal e Caminho 2.

A população também ocupa as margens do Rio Cubatão com o cultivo de hortas, como é o caso daquelas localizadas nos bairros Jardim Costa e Silva, Parque Fernando Jorge, Jardim das Indústrias e Conjunto Marechal Rondon - são bairros pequenos que margeiam rio.

Cotia-Pará, à Vila Natal e ao Conjunto Habitacional Governador Mário Covas.

${ }^{137} \mathrm{~S}$. Edgar conta que saiu com uns amigos pra pescar e resolveram trazer uns peixes e jogar por ali.

${ }^{138}$ São 720 apartamentos (aproximadamente 3.000 pessoas) que foram ocupados majoritariamente pelos moradores do Morro do Marzagão. Fonte: <http://www.novomilenio.inf.br/cubatao/> Acesso: maio de 2006 e Coordenadoria do Desenvolvimento econômico de Cubatão. 
No meio desses bairros também encontramos hortas, muitas delas em pequeninos espaços no meio das casas e ruas. Conforme a foto que segue:

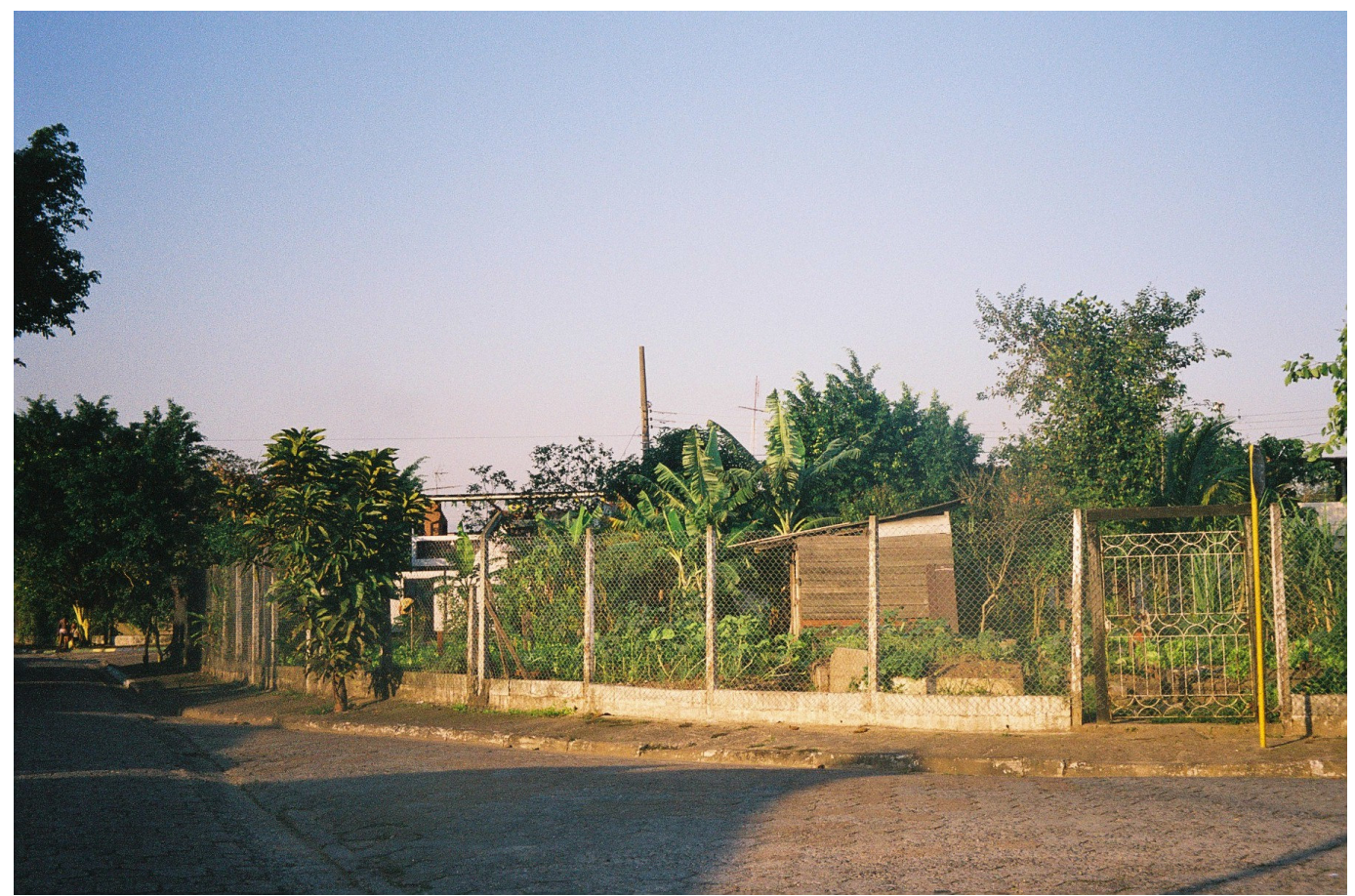

Figura 23: Horta localizada no Parque Fernando Jorge. (Data: 08/07/06) Fonte: Foto Vilma Aparecida da Silva

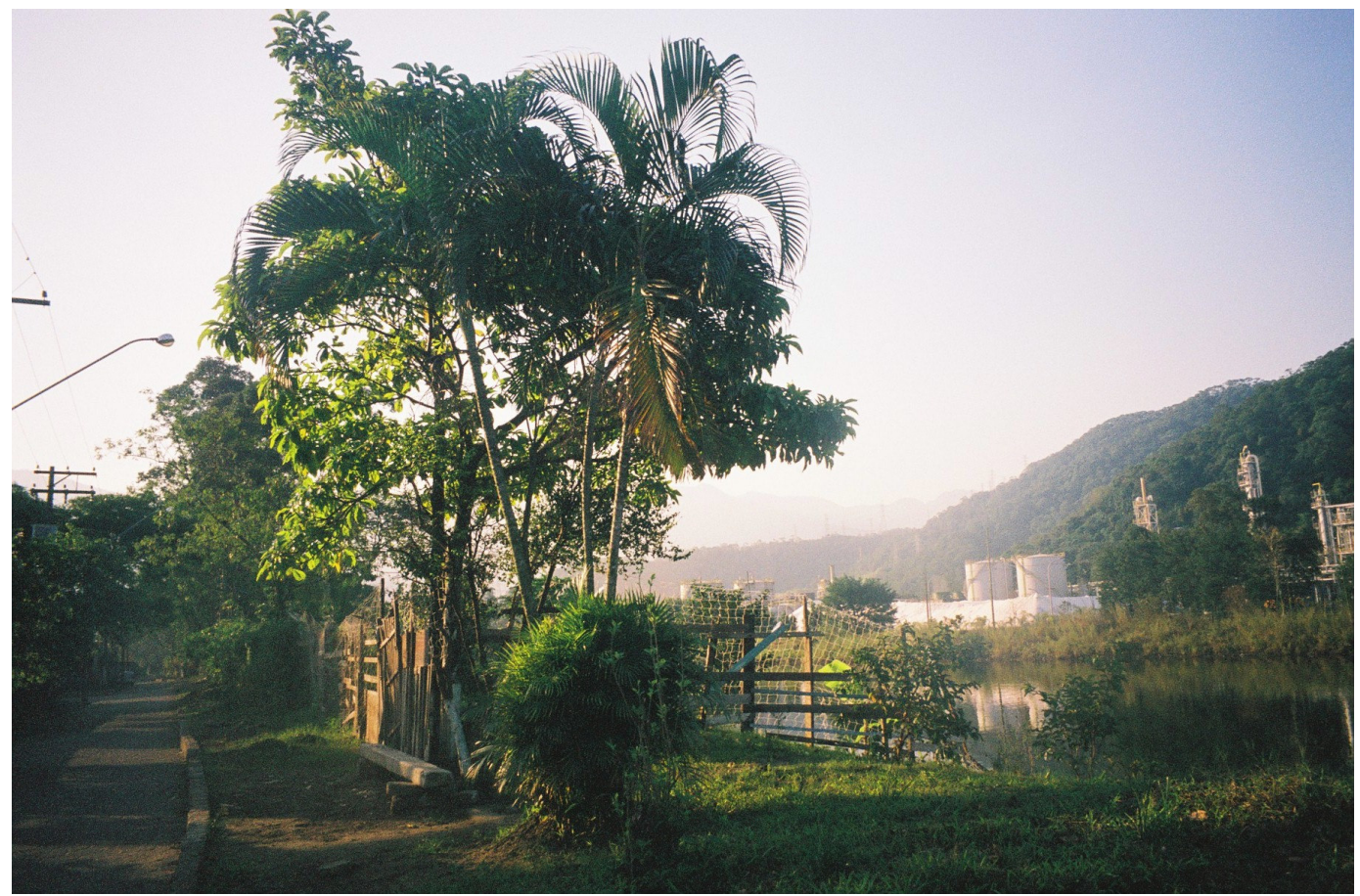

Figura 24: Em primeiro plano podemos observar a margem do rio Cubatão ocupada com hortas (Conj. Marechal Rondon). Ao longo dessa Avenida (à esquerda) as hortas seguem até o bairro seguinte, acompanhando o rio. A direita da foto fica a indústria Carbocloro. (Data: 08/07/06)

Fonte: Foto Vilma Aparecida da Silva 


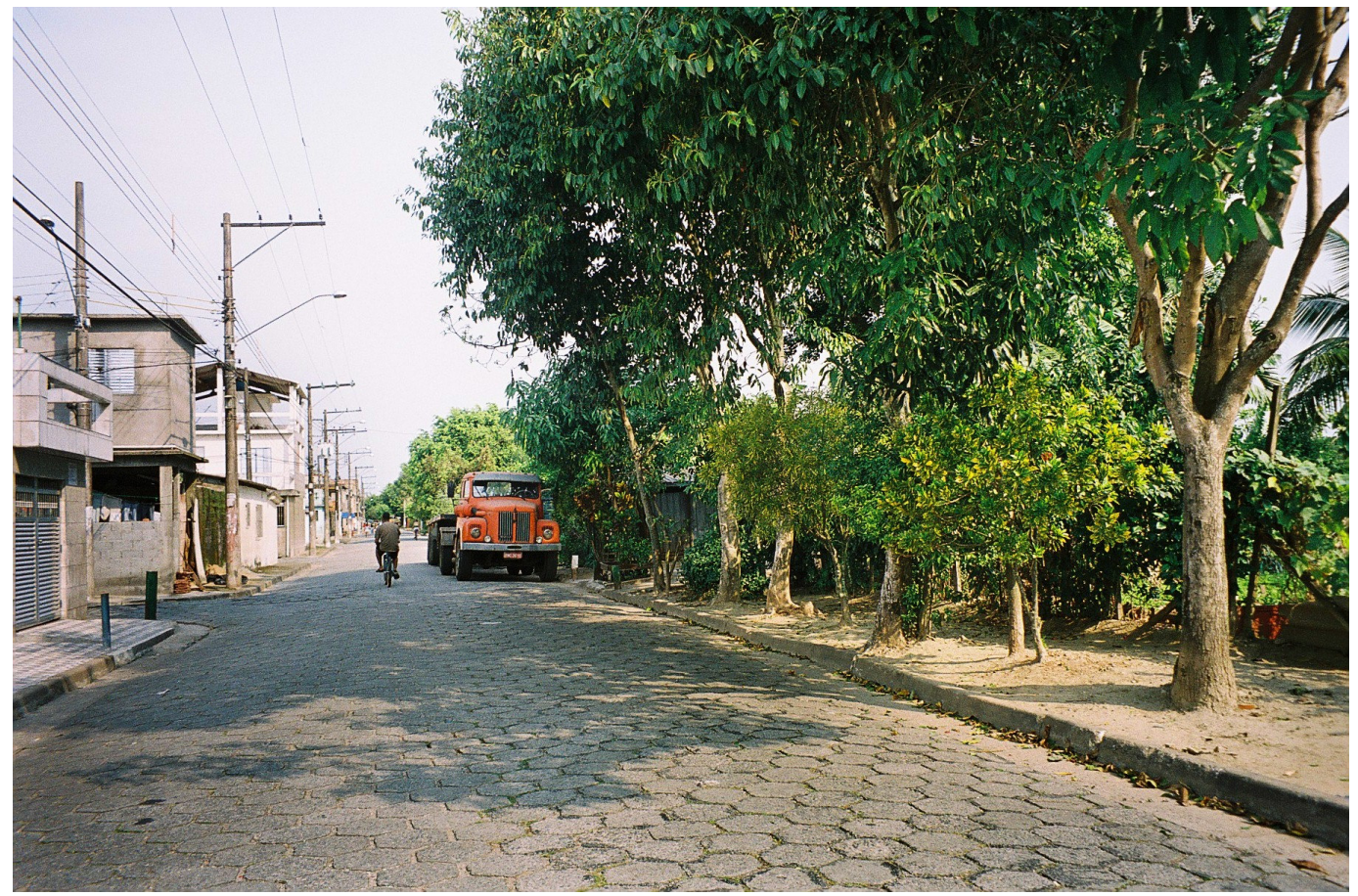

Figura 25: Foto de parte das hortas da Vila São José, as quais podemos observar no canto direito da foto. Logo atrás das hortas fica a Rodovia Anchieta. (Data: 24/08/05)

Fonte: Foto Vilma Aparecida da Silva

Ao longo da Via Anchieta (em sua pista ascendente) se localiza a Vila São José ${ }^{139}$, que mantém paralela à Rodovia, aproximadamente 40 hortas de tamanhos variados. Dona Maria conta que no final da década de oitenta nesse espaço tinha um matagal, mas, no começo da Vila, tinham algumas pessoas que plantavam - inclusive chegaram a receber uma vez adubos, sementes e terras da Prefeitura, nesse período. Foi então que iniciou o cultivo naquela parte da Vila, ela relata. O plantio é para consumo próprio, mas existe uma partilha entre os vizinhos, principalmente no que se refere às plantas medicinais. "Quando alguém pede algo da horta, ninguém se nega a dar", diz Dona Maria, ainda que não seja remédio. A irrigação é feita com baldes ou então "esperam a chuva molhar,". Embora a quantidade de hortas seja grande, houve uma época em que a Associação dos moradores quis acabar com elas, mas, mesmo diante de protestos, as hortas permaneceram.

\footnotetext{
${ }^{139}$ Esse bairro se originou a partir de uma ocupação irregular a partir da década de 1950, embora a fundação do bairro date de 1962. Está localizado próximo ao bairro Vila Nova e às margens da Rodovia Anchieta e da Avenida Doutor Tancredo de Almeida Neves, ocupando uma área de 13,1 hectares. Ficou conhecido como Vila Socó devido à abundância no local de uma ave chamada de socó. As casas da Vila foram construídas no mangue. Com o incêndio ocorrido em 1984, parte da Vila foi reconstruída em uma área próxima, passou então a ser denominada de Vila São José. Hoje tem uma boa infra-estrutura, com luz, água encanada, esgoto, pavimentação, escola e serviço de saúde. Fonte: <http://www.novomilenio.inf.br/cubatao/> Acesso: maio de 2006 e Coordenadoria do Desenvolvimento econômico de Cubatão.
} 
No Jardim São Francisco, às margens da linha férrea "MRS Logística S.A." encontramos uma horta (a cerca de 500 metros da Avenida principal - Nove de Abril) cuidada por S. Manoel, aposentado, morador do bairro. Segundo ele, já mantém a horta há onze anos. O terreno pertence à ferrovia, com placa indicativa de propriedade particular e de acesso proibido. No entanto, S. Manoel obteve uma autorização de uso da área, pois, segundo o entrevistado, "plantar e zelar é permitido". Iniciou com o plantio da banana, depois diversificou a plantação com outras culturas. Hoje planta quiabo, feijão, banana, abóbora, couve, alface, coentro, cebolinha, salsinha, entre outras coisas. O problema da água foi resolvido com um poço cavado no terreno, mas o restante necessário à manutenção da horta é continuamente trazido pelo dono da mesma, todos os dias. De sua produção, S. Manoel gera uma pequena renda que complementa sua aposentadoria, através da venda da banana para os vizinhos e pessoas que o abordam na horta. Os outros alimentos são para consumo próprio, cedendo às vezes uma pequena parte aos vizinhos e pedintes, conforme a quantidade obtida na colheita.

Ter uma horta não é tarefa fácil, é um trabalho árduo que exige tempo, dedicação, conhecimento e espontaneidade. É preciso arar a terra, plantar, regar, roçar, controlar possíveis pragas ${ }^{140}$ etc. Ainda assim aceitar a perda do plantio devido a chuvas e ventos, conforme relatos. A maioria dos entrevistados destacou as origens camponesas como fator primordial que impulsionou a criação e manutenção da horta. Mesmo um arquiteto da Prefeitura destacou essa pré-disposição como característica da população cubatense, que, segundo ele, tende a se apropriar de terras sem uso e dono (aparente) ou parcelas de terras - como margens de ferrovia ou de rios. A interpretação que alguns entrevistados fazem dessas áreas é que elas são terras disponíveis, passíveis de apropriação. O uso das mesmas apareceria como legítimo, não sendo aviltante a apropriação do ponto de vista da ética camponesa. A realização de práticas que remetem a uma ordem moral com base na ética camponesa ${ }^{141}$ se espacializa. É a subversão que se impõe; a resistência, a lógica do uso - as referências às dimensões da existência, os sentidos da vida,

\footnotetext{
${ }^{140}$ Como o escargot africano: Achatina Fulica trazido para o Brasil no final dos anos 1970 e que, solto na natureza, se transformou numa praga exótica, capaz de transmitir a angiostrongilíase (doença que pode levar à morte).Cf. Jornal "O Estado de São Paulo" caderno Agrícola, G 2, 19/01/05.

${ }^{141}$ Seabra (1986, p. $76-77$ ) ressalta o conflito entre os momentos racionais e os da apropriação no cotidiano. Enfim, lutas pelo uso, travadas no cotidiano entre o concebido e o vivido.
} 
como Seabra (1986) se refere. A espontaneidade nesse caso aparece como evidência do modo de uso desse espaço.

Sem dúvida, a subjetividade envolvida é bastante marcante nesse processo de apropriação do espaço. A horta, de certa forma, proporciona o reencontro do migrante com suas origens - expressa desejo, necessidade e vontade ${ }^{142}$. Existe uma preocupação, manifestada por muitos, em recriar antigos hábitos e costumes, atributos morais de épocas anteriores da vida na roça, no interior. Seria uma tentativa de recuperar, mas num processo de resignificação, um universo simbólico da vida rural. E conforme a cidade apresenta algumas brechas, a população expressa suas antigas práticas.

Nas proximidades do bairro São Francisco, encontramos um terreno que foi ocupado há aproximadamente 4 anos por dois moradores da cidade (um dos moradores reside no bairro Vila Nova e o outro reside na Vila dos Pescadores) ${ }^{143}$. Vivendo com dificuldades, resolveram ocupar o terreno e iniciaram a criação de porcos (inicialmente cinco), galinhas, codorna, ganso e pato. Chegaram a ter 200 cabeças de galinhas, mas hoje só têm 40 galinhas e 2 porcos. A diminuição foi devido ao ataque de um cachorro às criações. Nesse local podemos encontrar árvores frutíferas e legumes. Tem cana, caju, acerola, chuchu, tomate, banana, entre outras. Algumas culturas não tiveram sucesso, devido ao tipo de terra: mangue (aterrado).

A alimentação dos bichos é feita com lavagem (resto de alimentos) que eles conseguem com um primo que trabalha num supermercado da cidade. Colocam a lavagem em grandes recipientes e depois as acondicionam em uma carroça manual atrelada a uma bicicleta. A água utilizada vem da casa no terreno e eles pagam um pequeno valor ${ }^{144}$ acertado com o morador. Eles se referem ao local como "sítio" e transparecem grande preocupação com sua situação irregular. Como as condições de criação não são as melhores, os criadores reclamam dessa situação, desejando apoio do poder público para exercerem essa atividade ${ }^{145}$. "Não podem nem erguer uma cerca que a polícia derruba", diz a esposa de um deles. Mesmo correndo o

\footnotetext{
142 Sobre essa discussão ler Maia (1994).

${ }^{143} \mathrm{O}$ local onde esse entrevistado reside com sua família foi ocupado por eles há dois anos. A Vila dos Pescadores é área de mangue.

${ }^{144}$ Cerca de $\mathrm{R} \$ 12,00$ (doze reais) por mês.

${ }^{145}$ A Vigilância Sanitária e a Prefeitura Municipal de Cubatão proíbem a criação de animais na cidade.
} 
risco de serem expulsos desse terreno, e diante das dificuldades enfrentadas, esses trabalhadores permanecem no terreno.

$\mathrm{Na}$ área do Sitio Areais e Capivari ${ }^{146}$ tem plantação de algumas verduras. Especificamente no Sítio Capivari existe uma pequena propriedade com horta e seus residentes vivem da pesca e da ferração de cavalos. A habitação dessa área data do século XIX, perfazendo no total 13 hectares. Ambos estão às margens do rio Cubatão, sendo que os Areais se localizam à esquerda do mesmo e o Sítio Capivari à direta (no final do bairro Jardim São Francisco). Nas terras do Sítio Capivari está instalada uma Estação de Tratamento de Água da Sabesp. Por essas terras passa a malha da MRS (antiga Rede Ferroviária Federal - RFFSA). Esse local abrigava um antigo bananal com algumas famílias de baixa renda, porém, com a construção da Copebrás $^{147}$ em 1958 passou a ser local de moradia de outras famílias com vínculos empregatícios com a referida companhia. Em uma propriedade no Sítio Areais ${ }^{148}$, encontramos uma grande horta, criação de galinhas e patos, além de gado e cavalo.

A Vila São Vicente ${ }^{149}$ faz parte da área industrial da cidade, ocupando uma área de 1,3 hectares. Seu ponto central é a Praça Coronel Joaquim Montenegro (que abria o Largo do Sapo - local onde as mercadorias aguardavam para serem transportadas, durante os séculos XVII e XVIII). Nessa Vila encontra-se o Cemitério da cidade, o Corpo de Bombeiros, a Delegacia de Polícia, um pequeno teatro ${ }^{150}$, algumas casas e uma Organização Não Governamental (Grupo Lazer e Cidadania - GLC). Dentre as poucas casas existentes, uma possui horta. O Corpo de Bombeiros, construído e ocupado em 1976, possui uma horta criada nessa ocasião pelo soldado Macena (já aposentado) e que hoje é mantida por alguns soldados. Esta horta ocupa numa faixa

\footnotetext{
146 Fonte: <http://www.novomilenio.inf.br/cubatao/> Acesso: maio de 2006 e Coordenadoria do Desenvolvimento econômico de Cubatão.

${ }^{147}$ A Copebrás Ltda. é uma empresa fundada em 1955, com capital nacional, fabricando o Negro de Fumo no intuito de suprir a indústria nacional. O Negro de fumo é uma matéria prima utilizada na indústria de pneus, borrachas e plásticos. A companhia atualmente tem seu foco na produção de fosfato. Fonte: <http://www.copebras.com.br/index_port.htm>

${ }^{148} \mathrm{Em} 2002$ existiam 22 casas nessa área num total de 55 pessoas. A prefeitura removeu essa população para o Conjunto Habitacional Mário Covas (localizado na Vila Natal). Porém, como as casas não foram derrubadas, alguns moradores ainda fazem uso delas e de sua área com uma pequena plantação.

${ }^{149}$ No século XVII, funcionava nesse local "uma alfândega que teve uma intensa movimentação comercial por mais de dois séculos" e onde se desenvolveu o povoado que ficou conhecido pelo nome de Cubatão. (FERREIRA \& PASSERANI, 2005, p. 27).

150 Teatro do Kaos - fundado em 11 de janeiro de 1997 e reconhecido como Utilidade Pública Municipal pela Lei $n^{\circ}$. 2.576/99.
} 
estreita de terra entre o prédio e um córrego (este paralelo à mesma linha de trem que corta o Jardim 31 de Março). O destaque da horta é a diversidade de bananas plantadas e outras frutas e plantas (como pé de café). Chegaram a ter criação de galinhas e porcos. Como o Corpo de Bombeiros atende ocorrências envolvendo abelhas, eles mantêm um pequeno apiário, nesses casos contam com o apoio de S. Luis (apicultor nos Pilões, residente na Vila Nova). Tanto a manutenção da horta como a criação de animais é algo muito questionado pela Corporação.

A ONG "Grupo Lazer e Cidadania", situada na mesma Vila, também mantém uma horta. Atualmente sua presidenta está desenvolvendo um projeto de criação de peixes no rio Cubatão, uma vez que a ONG faz fundo com o rio.

Além dessas hortas, encontramos na mesma faixa de terra ocupada pelo Corpo de Bombeiros, uma horta cuidada (há cinco anos) por uma funcionária do cemitério. $\mathrm{A}$ horta de Dona Helena surpreende pela diversidade de cultivos. Ela também tem caixotes com abelhas (uns próximos à horta e outro com o Corpo de Bombeiros). A terra vem do Horto Florestal, já que por ali passava um pequeno riacho que foi desviado. S. Eduardo que trabalha com um carrinho de doces na frente ao velório contou-nos que há onze anos atrás ele e um colega plantaram ali algumas mudas de bananas e iniciou a horta, mas hoje apenas ajuda Dona Helena na manutenção da mesma.

Uma vez constituídos os espaços de hortas, fica o seu usuário com a posse informal da área, cedendo o direito de uso para terceiros, conforme desejar. Isso acontece no caso em que o usuário mude do município, precise se afastar por motivos de doença ou venha a falecer. Então seu direito de uso é cedido a outrem. Encontramos um caso em que uma horta estava meio abandonada, então o responsável pela mesma atualmente chegou a pedir o uso do espaço - que foi concedido pelo antigo usuário. Podemos pensar no espaço da horta como um espaço social diferenciado, podendo ser comparado ao espaço do roçado, submetido às regras das relações familiares. Em certo sentido, ele representa, para muitos, um fragmento do território camponês (com certa liberdade). Poderíamos dizer que na ética camponesa é o trabalho que faz o dono. Desta forma, o direito de uso desse espaço é respeitado.

Embora tivéssemos alguns relatos de furtos de verduras etc em algumas hortas, esse tipo de problema está controlado. Os mantenedores de hortas apenas têm o 
cuidado de cercar a área,como forma também de delimitar o espaço de plantio que Ihe pertence. No caso das hortas do Jardim 31 de março, alguns cachorros que são mantidos dentro da horta servem justamente para evitar possíveis roubos, segundo os entrevistados.

Durante nossa pesquisa também encontramos pessoas que mantêm pequenos canteiros em casa (como é o caso de $\mathrm{S}$. Carlos que montou uma pequena horta na laje de sua casa) e uns até no trabalho (quando é possível). Há muitos casos em que as pessoas moram em um determinado bairro e mantêm sua horta em local distante.

A criação de aves é algo ainda tolerado pelo poder público, o que não acontece em relação a porcos, bois, vacas e cavalos (esses são parcialmente tolerados). Embora seja proibida a criação desses animais fora de sítios ou propriedades afastadas, há criação clandestina dos mesmos. Alguns entrevistados mencionaram a criação desses animais não só para consumo como também para a venda. Muitos sobrevivem da venda desses animais, como S. João - natural de Pernambuco, onde plantava roça, comprava e vendia porcos na feira de sua cidade. Diante da situação de desemprego em Cubatão, ele decidiu criar porcos. Atualmente consegui comprar um pedaço de terra nas proximidades da Vila Esperança (mas já em terras do município de São Vicente) para onde irá transferir sua criação, devido aos problemas enfrentados com a Vigilância Sanitária. Mas permanecerá morando em Cubatão. Muitos criadores acabam aderindo a essa prática de transferir a criação para outro município, mantendo chácaras, sítios ou um pedaço de terra em cidades como São Vicente, Pedro de Toledo, Mongaguá e Peruíbe. 


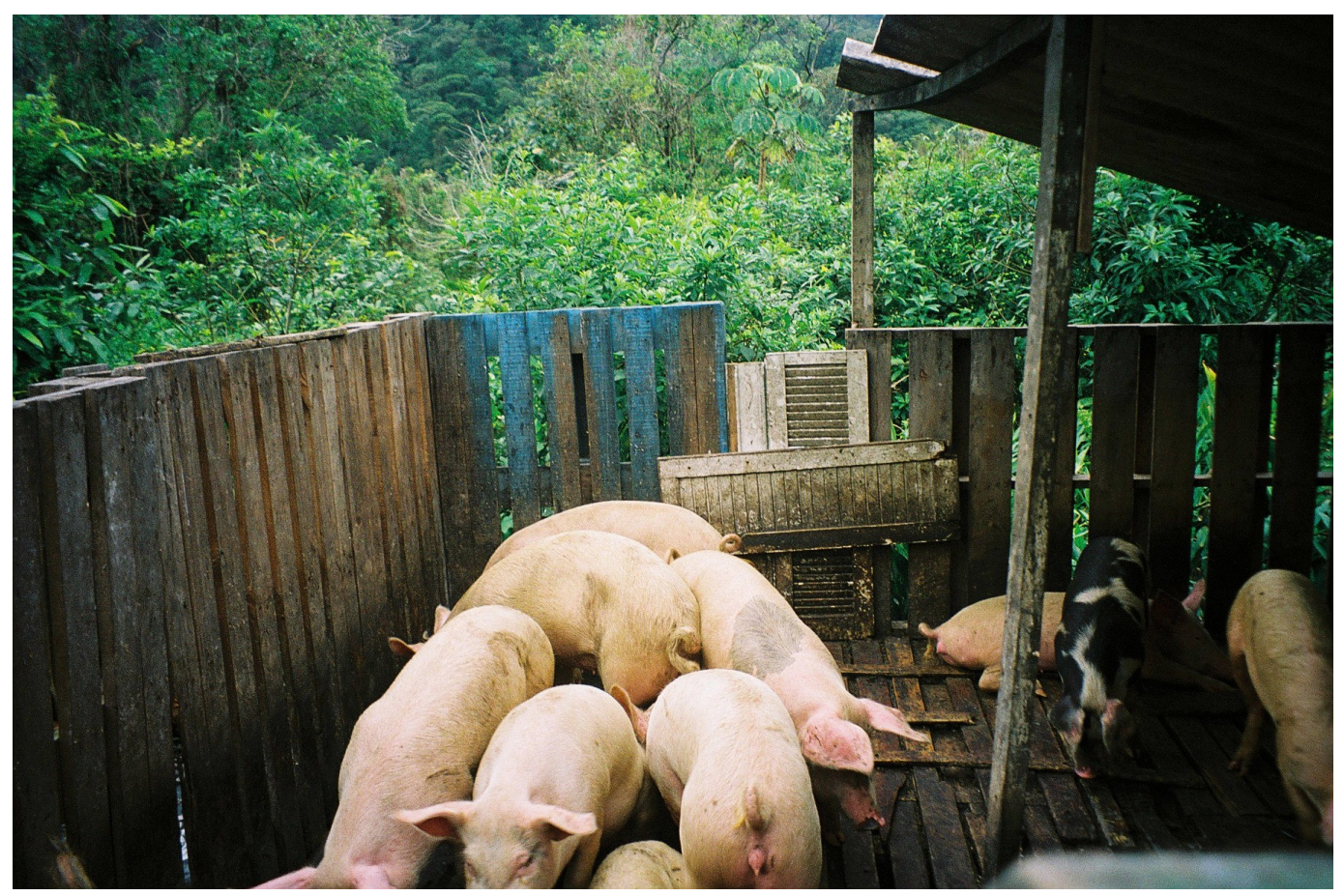

Figura 26: Nesta foto observamos uma criação de porcos clandestina. (Data: 26/08/05) Fonte: Foto Vilma Aparecida da Silva

Então o que o município tinha que fazer? A política correta que tinha que se fazer: montar um esquema, um matadouro decente, comerciável, fiscalizado, sabe? E não fazer com que o matuto tivesse que sair pra outros centros ou correr atrás de outras coisas e principalmente passar fome. (Entrevistada pela autora, maio/2006)

A política do Município muitas vezes é questionada, principalmente pelos criadores de animais de pequeno porte, que gostariam de exercer suas atividades de forma legalizada. Por isso muitos deixam de criar, ou não criam na quantidade que desejam, segundo um entrevistado. "Por que a finalidade é o que? É, justamente, é a cultura dele... Ele queria criar cem, mas ele falou: 'Não, vou criar um!'." (Entrevistado pela autora, junho/2006)

Um entrevistado nos relatou que na década de 1990 chegou a ter 200 patos/patas e 120 porcos no quintal da casa onde morava (um terreno de $35 \mathrm{~m} \times 70 \mathrm{~m}$ ); e os vendia já abatidos na Rua São Paulo, situada no centro da cidade. Como a criação desses animais era considerável na cidade, chegaram a criar em 1992 uma "Associação dos Criadores e Abatedores de Carne Suína, Bovina, Caprina e Ovina de Cubatão”, mas, diante dos conflitos com o poder público e com a Vigilância Sanitária, a associação 
deixou de existir formalmente. E muitos criadores passaram para a clandestinidade. É importante destacar que quando a associação dos criadores foi criada, já existiam pessoas em Cubatão exercendo a criação e o abate de animais há mais de vinte anos.

Além da criação de animais, a pesca também aparece como uma atividade diferenciada na cidade, exercida por alguns poucos pescadores que residem principalmente na Vila dos Pescadores (área de ocupação), próximo ao Jardim Casqueiro.

A situação precária ${ }^{151}$ vivida pela grande maioria dos habitantes da cidade coloca como alternativa o cultivo de alimentos e a criação de animais, ainda que em condições questionáveis.

A disponibilidade dos terrenos e a pré-disposição de alguns moradores (muitos com raiz camponesa) se apresentam como fatores importantes na discussão sobre a agricultura urbana desenvolvida em Cubatão. De qualquer forma, a situação de aposentado confere um tempo disponível para o exercício desse tipo de atividade.

Embora não existam grandes incentivos ao desenvolvimento da agricultura urbana em Cubatão por parte do poder público, as atividades são evidentes e marcantes na paisagem, apresentando um componente expressivo em suas práticas: a campesinidade $^{152}$, ou seja, a expressão de uma ordem moral a partir da ética camponesa, que naturalmente encerra conflitos em sua espacialização na cidade. Conforme Seabra (1986, p. 76):

Esse conflito traduz-se numa luta pelo uso, pela apropriação, que absolutamente não é nem poderia ser entendida como marginal, à parte do todo, fora da sociedade e do social. Nesses termos, se o uso se insurge e ganha visibilidade, restabelece a dialética da

\footnotetext{
${ }^{151}$ Um entrevistado fala da necessidade da criação para esse cidadão mais carente: "Está criando aqueles um, dois, para ele, pelo menos, ter um entretanto dele, né!?”. (Entrevistado pela autora, junho/2006).

152 Klaas Woortmann (1990) conceitua campesinidade como sendo "uma qualidade presente em maior ou menor grau em distintos grupos", tais grupos se movimentariam ao longo do tempo e do espaço numa espécie de contínuo, desde um pólo de máxima até outro de mínima campesinidade. A campesinidade, segundo esse autor, seria então comum a diferentes lugares e tempos.
} 
propriedade em outros termos, em outros planos. É um processo que pressupõe atos práticos.

A ocupação do espaço em Cubatão com atividades agrícolas é feita em espaços dispersos e fragmentados que são apropriados por moradores que residem próximo ou distante desses espaços. O município é cortado por rodovias e ferrovias, essa forma adquirida pela cidade no decorrer de sua história disponibilizou terras. A própria reprodução do espaço através da intervenção do Estado e de empresas no processo de apropriação da terra, de certa forma pode ter contribuído para a existência das atividades agrícolas no meio urbano. No entanto, os fatores preponderantes nesse tipo de apropriação foram: a existência de pessoas com raiz camponesa apresentando determinado grau de campesinidade e a disponibilidade de tempo para o exercício de práticas que remetem ao universo rural e de áreas em condições específicas. Mesmo diante de algumas dificuldades surgidas, a subversão se impõe, dando lugar ao desejo e a espontaneidade desses sujeitos sociais que através das brechas do sistema encontram uma forma de dar sentido a sua existência e de buscar alternativas de sobrevivência. A ruralidade em Cubatão então não só permanece em alguns locais específicos como também é recriada.

\subsection{Modernidade e Vida Cotidiana}

A realidade brasileira encerra grandes contradições e nos coloca diante alguns desafios para sua interpretação. É nesse contexto que a modernidade ${ }^{153}$ precisa ser analisada; considerando a história do desenvolvimento do capitalismo no Brasil como sendo marcada pela presença viva e ativa de estruturas do passado, apontando processos sociais bastante complexos.

\footnotetext{
${ }^{153}$ A modernidade embora tenha surgido "na consciência social no século XVIII... é no século XIX que ela encontra sua explicação sociológica inicial”. (MARTINS, 2000, p. 19). É "a realidade social e cultural produzida pela consciência da transitoriedade do novo e do atual... não é feita pelo encontro homogeneizante da diversidade do homem... é constituída ainda, pelos ritmos desiguais do desenvolvimento econômico e social, pelo acelerado avanço tecnológico, pela acelerada e desproporcional acumulação de capital, pela imensa e crescente miséria globalizada, dos que têm fome e sede de justiça, de trabalho, de sonho, de alegria. A modernidade anuncia o possível, embora não o realize... A modernidade se propõe muito mais como estratégia de compreensão e de administração das irracionalidades e contradições da sociedade capitalista do que como disseminação ilimitada da racionalidade ocidental e capitalista... é o transitório e a consciência do transitório... integrante do moderno". (MARTINS, 2000, p. 19-23). A modernidade não se confunde com objetos e signos do moderno, ela se caracteriza pela desigualdade e pelo desencontro.
} 
A reprodução da cultura camponesa dentro da sociedade capitalista se apresenta como um movimento contraditório, de modo que as condições de sua reprodução são engendradas pela própria reprodução do capital. É preciso ressaltar que as relações capitalistas de produção não destroem e nem corroem necessariamente as relações que trazem consigo a legitimidade de outras épocas (MARTINS, 1997).

Para Martins (2000), nós somos portadores de uma lógica "assimilacionista e integradora", uma vez que tornamo-nos capazes de integrar o novo sem a destruição daquilo que é antigo. Isso nos insere na modernidade de forma bastante peculiar, permitindo diferentes formas de apropriação do moderno e seus signos. Mas, vale salientar, conforme o autor citado, que é a tradição que agrega fragmentos do moderno, sem agregar um modo moderno, e não o moderno que incorpora o tradicional e o popular. A modernidade em que vivemos integra o moderno e o tradicional, com suas respectivas contradições. E, ao deixar evidentes os problemas e as contradições, ela também é a "consciência do moderno".

Todavia, nossa consciência moderna é incompleta, como nos propõe Martins, pois, nossa alienação aparece como uma entrega parcial à racionalidade, ao contrário dos países desenvolvidos, onde há uma entrega completa à racionalidade do capital. Esta nossa característica sugere uma análise das contradições do capital que dê conta também das especificidades do nosso modo de ser. Nosso hibridismo cultural $^{154}$ se revela como sendo o que Martins chama de multiplicidade cultural híbrida com tendência à ambigüidade constante, expressa na vida cotidiana (gestos, condutas e mentalidades - presentes no nosso modo de ser, de vestir, entre outros). Essa vida cotidiana se transforma em obstáculos à modernização.

Para Woortann (1990, p. 13), a história pode ser percebida "como uma contínua produção e resolução de ambigüidades". No caso da realidade brasileira, muitas vezes observamos a convivência de concepções aparentemente antitéticas: convivem concepções morais ${ }^{155}$ com concepções utilitaristas mercantis, num campo de forças caracterizado pela ambigüidade, segundo Woortann. Por isso, o autor diz

\footnotetext{
${ }^{154}$ Para Martins (2000, p. 43-50), o hibridismo seria uma "(...) mescla do que não é igual nem contemporâneo".

${ }^{155} \mathrm{Um}$ exemplo dado pelo autor é a terra como valor de uso.
} 
que encontramos uma campesinidade em graus distintos de articulação ambígua com a modernidade, e não camponeses puros.

Uma modernidade inconclusa abre brechas a práticas sociais reveladoras, portanto, a interpretação da realidade passa também pelo entendimento do mundo rural, de seus valores, tradições, de uma moral camponesa que ainda está muito presente na realidade brasileira. A capacidade de conciliar aquilo que é antagônico, através de uma lógica assimilacionista e integradora se apresenta, segundo Martins (2000), como uma estratégia social, uma forma de resistirmos à inovação e à transformação. Seria uma tentativa de preservação cultural. Assim, nos caracterizaríamos como sujeitos que tendem a uma ambigüidade constante, vivendo a lógica do duplo (do ser e do parecer ser) como verdadeira orientação cultural.

"A dissimulação, como contrapartida da repressão e do controle social, ineficientes e complacentes, indica que a sociedade brasileira não impugna nem viabiliza completamente os comportamentos tradicionais, irracionais e discrepantes. Apenas indica que o cenário principal da visibilidade social tem de ser ocupado pela teatralização do moderno e do racional, mas sobretudo do dominante." (MARTINS, 2000, p. 51).

Essa discussão destaca a supervalorização das formas e exterioridades, como supõe o barroco, por isso "nossa cultura continua sendo barroca".

Desta forma, a sociedade brasileira apresenta uma modernidade frágil, constituída por temporalidades diversas ${ }^{156}$, marcadas pelos ritmos desiguais de desenvolvimento econômico e social. Conforme a lei do desenvolvimento desigual, as forças produtivas, as relações sociais e as superestruturas (culturais, políticas) não avançam no mesmo ritmo histórico, isto é, não avançam igualmente, simultaneamente no mesmo ritmo histórico. Há, assim, um desencontro entre o econômico e o social. Esse desenvolvimento é desigual e combinado, pois agrega

${ }^{156}$ Essas temporalidades diversas (históricas) se realizam no espaço e o definem, segundo Damiani (2005). 
formações e estruturas de outras épocas. O conceito de totalidade considera também o diverso ${ }^{157}$ (a unidade do diverso) (MARTINS, 1986).

Henri Lefebvre reconhece uma dupla complexidade, horizontal e vertical. A complexidade horizontal refere-se a diferenças do espaço natural, podendo ser reconhecida na descrição do visível.

A modernidade encerra contradições sociais históricas que representam não só confrontos de interesses entre categorias sociais diferentes, mas também desencontros de tempos e de possibilidades. Nesse contexto existem necessidades não atendidas plenamente, alternativas não consumadas e virtualidades não realizadas (MARTINS, 1986).

Essa complexa realidade social na qual nos encontramos se revela principalmente na vida cotidiana.

A vida cotidiana se instaura quando o ser humano começa a ser fragmentado, passando de pessoa a indivíduo, um processo que se iniciou com o desenvolvimento do sistema capitalista. Seabra (2004) conceitua a vida cotidiana como uma articulação que totaliza espaço e tempo na modernidade; que reúne e distingue, em diferentes níveis, o singular e o universal, o particular e o geral, o abstrato e o corpóreo; articula o viver (que corresponde à dimensão das práticas) e o vivido $^{158}$ (que integra a subjetividade, perpassado por retórica e por estetismos) e desta forma, integra todas as representações do mundo. A vida cotidiana "como conceito refere-se aos conteúdos da vida na modernidade, os quais seguem sendo transformados pelas tecnologias do cotidiano e por elas modulados, caracterizando uma maneira de viver ou modo de vida regido pela lógica da mercadoria". (SEABRA, 2004, p. 190).

\footnotetext{
157 O diverso não é necessariamente o contemporâneo, ou apenas o diferente.

158 Para José de Souza Martins, o vivido é a vida de todo dia, contraditória, desencontrada. É no vivido que as pessoas tomam consciência das contradições. O vivido diz respeito a uma dimensão da práxis (repetitiva e inovadora), do ritmo desigual e não da uniformidade, uma forma de experimentar os ritmos da desigualdade de tempos, de possibilidades. Aquilo que apenas se anunciou também é o vivido. É a vida cotidiana (MARTINS, 2002).
} 
No cotidiano ${ }^{159}$, não há somente a rotina, mas a insurgência e a consciência crítica também podem se manifestar. $\mathrm{Na}$ instauração da modernidade, a vida cotidiana encerra o possível ${ }^{160}$ através das contradições e ambigüidades vivenciadas. Ou seja, embora a vida cotidiana capture a contradição entre o valor de uso e o valor de troca, ela é também o lugar do uso. É no cotidiano que se instaura o embate entre o valor de uso e o valor de troca, já que ele inclui a sociabilidade, a subjetividade, o vivido, os hábitos e os comportamentos, onde a ordem próxima (o local) é atravessada pela ordem distante (o global).

No entanto, na sociedade em que vivemos, "o processo de reprodução indica a tendência da predominância da troca em relação ao uso" (CARLOS, 1986, p. 176). A produção do espaço, em escala mundial, se dá, portanto, através de processos que buscam homogeneizá-lo, através da ação política aplicada pelo Estado ${ }^{161}$. Com base na obra de Lefebvre, Carlos explica que "o espaço estatista se insere entre o espaço pulverizado e o construído diferencialmente segundo o uso, que o Estado tenta subordinar e abolir". (CARLOS, 1986, p. 132). Mas essa tentativa de homogeneização é interrompida pela fragmentação que também é gestada durante o processo de homogeneização. Colocam-se então possibilidades de ruptura, que conferem à reprodução do espaço um caráter contraditório. E, para a compreensão da problemática urbana que se coloca, é preciso considerar diferentes aspectos sociais, e o que aparentemente é insignificante, como nos propõe Martins (2000, p. 13):

É nos limites, nos extremos, na periferia da realidade social que a indagação sociológica se torna fecunda, quando fica evidente que a explicação do todo concreto é incompleta e pobre se não passa pela mediação do insignificante. É nesses momentos e situações do protagonismo oculto e mutilado dos simples, das pessoas comuns, dos que foram postos à margem da História, do homem sem qualidade, que a sociedade propõe ao sociólogo suas indagações mais complexas, seus problemas mais ricos, sua diversidade

\footnotetext{
${ }^{159}$ Resultado da complementaridade entre industrialização e urbanização (SEABRA, 2004). A mesma autora define cotidianidade como o ritmo estabelecido na dialética do viver e do vivido.

${ }^{160}$ Sobre isso ler Henri Lefebvre.

161 O espaço é transformado e aparece como um instrumento de dominação. A técnica e as potencialidades econômicas contribuem para a homogeneização, segundo Carlos (1986).
} 
teoricamente mais desafiadora. São os simples que nos libertam dos simplismos, que nos pedem a explicação científica mais consistente, a melhor e mais profunda compreensão da totalidade concreta que reveste de sentido o visível e o invisível. O relevante está também no ínfimo. É na vida cotidiana que a História se desvenda ou se oculta.

Destacando a riqueza que encerra a análise do cotidiano, Martins destaca o Homem comum, das classes subalternas, como portador de uma visão mais ampla e rica da sociedade, justamente por viver os detalhes da realidade, seus vários ritmos e desencontros, se humanizando nesse desencontro. Segundo Marques (2002, p. 109):

(...) o trabalhador brasileiro experimenta uma diversidade de condições de vida e vai tecendo entre o campo e a cidade uma teia de relações que assegura a sua sobrevivência. Neste movimento, verifica-se tanto a recriação de práticas e tradições rurais em espaços liminares nas periferias das cidades, quanto a adoção de valores e padrões de consumo urbanos no campo.

$\mathrm{Na}$ visão da autora, a experiência de exclusão social vivenciada por esses sujeitos sociais contribui para elevar as categorias e valores tradicionais, de origem rural, a uma posição de destaque na visão de mundo dos mesmos. Tais valores e categorias podem ser observados na prática social dos nossos entrevistados.

O processo de exclusão ${ }^{162}$ vivenciado por muitos pode impulsionar muitas experiências rurais na cidade, como, por exemplo, as hortas. Sobre essa questão, Damiani (2000) ressalta a utilização da tradição como forma de demonstrar os limites colocados pela modernidade excludente na qual estão inseridos.

Além da coexistência das temporalidades diversas, a modernidade em que vivemos coloca o problema da exclusão e da fragmentação. A articulação desses fatores abre possibilidades de novas relações, estruturadas a partir do resgate de valores da ética camponesa. Esse resgate não é feito através de uma pura transposição de

\footnotetext{
162 Para Martins (1998), a dinâmica dessa sociedade se baseia em processos de exclusão para incluir. Portanto, para o autor, o que existe são formas perversas de inclusão, que consistem na degradação das pessoas e na desvalorização do trabalho, transformando-a em consumidores marginais.
} 
valores, mas de uma apropriação e resignificação dos mesmos em outro contexto. Utiliza-se, portanto, na constituição de nossa modernidade, o recurso do conservadorismo e do tradicionalismo (MARTINS, 2000). E é através dessa perspectiva que analisamos as formas de espacialização do migrante com raiz camponesa no contexto urbano em Cubatão.

Foi a partir da observação das atividades agrícolas que conseguimos apreender uma dinâmica maior que revela conteúdos significativos sobre o rural e o urbano, a categoria apropriação, a reprodução do espaço, suas contradições e a relação com a ordem moral de base camponesa.

Para Lefebvre, diante do descompasso do vivido, o ser humano, não só reproduz relações, mas, ao mesmo tempo, modifica suas condições. Pois, durante o processo de reprodução há, de certa forma, uma inovação (produção). E nesse movimento ele humaniza-se. (MARTINS, 1986).

\subsubsection{Atividades agrícolas, a criação de animais e a campesinidade}

Para Woortmann (1990), terra, trabalho e família constituem valores fundantes das sociedades camponesas, além das noções de reciprocidade, honra e hierarquia que se interpenetram na constituição da ordem moral camponesa - permitindo o entendimento da campesinidade em sua dimensão mais geral. A seguir, procuramos discutir esses valores, além de expor também uma breve reflexão sobre a festa e o lazer, que exprimem momentos reveladores dessa moral.

Entendemos por campesinidade, segundo Woortmann (1990), como sendo uma "qualidade presente em maior ou menor grau ${ }^{163} \mathrm{em}$ distintos grupos específicos". Tais pessoas expressariam, dessa forma, valores subjetivos com base na ética camponesa.

Para discutirmos a presença da campesinidade em Cubatão, vale destacar, primeiramente, que a maioria da população cubatense é composta de migrantes ${ }^{164}$,

\footnotetext{
${ }^{163}$ Este grau pode variar de acordo com a trajetória de vida do sujeito, ou do grupo, e também com a sua forma de integração à sociedade capitalista.

${ }^{164}$ Devido à instalação do pólo petroquímico a partir da década de 1950.
} 
que são, em grande parte, de origem rural. O aumento populacional foi vertiginoso com a industrialização. Em 1940, a população era de 6.570 pessoas, em 1970 esse número aumentou consideravelmente para 50.906, e conforme os dados do último censo $^{165}$ (2000) a população do município é de 108.309 habitantes. "A cidade se torna nordestina, quanto à população que passa a abrigar e, ao mesmo tempo se internacionaliza, quanto à riqueza gerada em seu espaço" (DAMIANI, 1984, p.13). A cidade se expandiu com o processo de industrialização, apresentando espaços fragmentados, favelas e ocupações irregulares, muitas delas na Serra do Mar e em área de mangue.

As atividades agrícolas são, em sua grande maioria, desenvolvidas por esses migrantes que se estabeleceram na cidade. Até a década de 1950, havia grandes propriedades rurais - principalmente onde a cultura da banana era praticada. Mesmo aquelas pessoas que não possuíam grandes propriedades, mantinham pequenos cultivos - como a plantação de bananas, frutas, verduras, legumes e alguns porcos, já que também viviam em condições precárias.

A cultura da banana, drasticamente reduzida em função da instalação das indústrias, já não domina mais a paisagem, mas resiste em alguns espaços ao longo do Vale dos Pilões e outras localidades pontuais. Porém, de maneira geral, a malha urbana apresenta atividades agrícolas em seu interior. Dentre as pessoas que ainda exercem essas atividades, estão muitos migrantes. Eles se dedicam à criação de animais de pequeno porte, como porcos, cabritos e aves, vacas, cavalos e à manutenção de hortas e pequena lavoura. Alguns sobrevivem dessas atividades, porém, a grande maioria é formada por assalariados e aposentados, que exercem essas atividades como manutenção de antigos hábitos rurais. Todos têm em comum uma vida humilde e sacrificada.

Quando indagados sobre a razão de exercerem essas atividades, os entrevistados afirmam ser por gosto, prazer, paixão, satisfação, necessidade, vontade, e principalmente por terem uma raiz camponesa. Eles dizem que foram criados na roça, que estão acostumados com a terra, e que isso é uma questão de sangue. Muitos demonstram a preocupação não só em manter essas raízes, mas em

165 Todos os dados estatísticos apresentados neste item têm como fonte o Instituto Brasileiro de Geografia e Estatística (IBGE). 
perpetuar os valores morais da cultura camponesa em sua posteridade. Quanto à motivação, observemos alguns relatos:

Eu acho que devido, não sei, à questão de sangue, sei lá, não sei te dizer, genética talvez... Nunca deixei de ser pé na terra, não consigo deixar. (entrevistado pela autora, maio/2006)

É, acho que já vem do sangue mesmo, né, aí então eu sempre gostei de mexer. (entrevistado pela autora, janeiro/2004)

Então, a nossa trajetória, para que a gente tenha uma raiz de lá para cá, nós temos que tentar manter aquela raiz, tentar manter aquela árvore... Então, eu acho que essa cultura nossa, os imigrantes, os nordestinos, ela tem sempre que ter uma raiz, uma base. Qual é a base? É você não esquecer de onde você veio. E falar para os seus filhos. Lógico que todos eles não vão ser igual, mas se você for lapidando, for lapidando, for lapidando, eles vão pegando aquela raiz da família e eles vão fazendo a coisa acontecer, porque amanhã eles vão ser pai, depois vão ser também avô e vai na seqüência. Então, nós temos que deixar sempre isso plantado, para uma cultura não perder, né? Para a cultura não perder, não perder a essência da cultura de quando a gente era pequeno, que os pais da gente era mais pequeno do que nós e os avô, você vê que é uma trajetória longa, mas essa trajetória longa, ela tem que ser cada vez mais aperfeiçoada no passado. (entrevistado pela autora, junho/2006)

Eu nunca perdi a raiz... (entrevistado pela autora, julho/2006)

Fui criado na roça e sempre gostei de criar bicho...( entrevistado pela autora, julho2006)

A gente se acostuma com uma coisa... A gente gosta. Toda vida eu gostei de criação. E o cabra que gosta de criação em todo lugar que ele chega ele cria! Chega alguém e diz que não, mas a gente se tivesse dinheiro compraria só criação. Eu gosto de criação demais, eu nasci pra isso! A gente tem aquela paixão. Quando eu vejo um bicho meu doente eu vou lá e dou vacina, separo - tipo um filho. Gosto de zelar, tenho amor, paixão. Agora matar (os animais), como eu vivo disso, é da vida. (entrevistado pela autora, agosto/2005) 
Os relatos expressam paixão, desejo, gosto em estar na terra, em plantar e conviver com animais. Félix Guattari (1993, apud MAIA, 1994, p.144) alega que o "desejo corresponde a todas as formas de vontade de viver, de vontade de criar, de vontade de amar, de vontade de inventar uma outra sociedade...". Acreditamos que a interpretação das falas de nossos entrevistados se insere dentro dessa colocação de Guattari, pois a vida passa pela necessidade, pelo desejo.

"Meus bois não são para corte, ao contrário, só crio leiteiro. É só para uso, eu não comercializo. Eu tenho os bichos por puro bel-prazer. Puramente bel-prazer. Eu não tenho necessidade de viver dos bichos." (entrevistado pela autora, maio/2006).

Além dos animais, Seu Pedro também mantém uma horta e faz doma de animais. Ele reside, há vinte anos, em um terreno que, em sua maior parte, foi aterrado por ele, pois era um aluvião ${ }^{166}$. Seus familiares chegaram a criar porcos na área, antes dele ir residir no local. Como é um local determinado como zona industrial, Seu Pedro é constantemente pressionado a desocupar suas terras, embora tenha a posse da mesma, dada pelo juiz. Mas o que garante sua subsistência é o emprego público. A doma, a criação de animais e a plantação são atividades que ele realiza por prazer.

O prazer em lidar com a terra, ou criar algum animal é associado à experiência de vida no campo e passa, muitas vezes, pela razão da existência desses migrantes, dando sentido às suas vidas. Nas falas de nossos entrevistados percebemos uma necessidade, vontade em estabelecer relações comunais entre seus vizinhos e conhecidos. A partilha dos alimentos é realizada por todos que entrevistamos, mesmo colhendo pouco, eles, ainda assim, distribuem a colheita entre vizinhos. $E$ também nunca negam coisa alguma a qualquer um que venha solicitar, principalmente as ervas medicinais, que eles fazem questão de cultivar, pois "não plantam só para si, mas também para os outros". O plantio dessas ervas é importante, pois atende a uma necessidade, representando uma alternativa à precariedade das estruturas de saúde do município, diminui a dependência de remédios alopáticos ("de farmácia”, como dizem), que envolvem gastos, e também porque guarda a dimensão cultural: são conhecimentos que são preservados e

\footnotetext{
${ }^{166}$ Segundo o entrevistado, até o capim (braquearia) que existe lá foi ele que plantou.
} 
resgatados. Para cada mal, um remédio, é impressionante a variedade de plantas medicinais cultivadas nas hortas. Entre os entrevistados, há reconhecimento e valorização desse tipo de saber.

O cuidado e a atenção dispensada às coisas da terra, aos animais não pode ser confundido com o zelo puro e simples, devendo ser compreendido a partir da perspectiva dos valores trazidos de uma experiência vivenciada em outro espaço. Como podemos observar na descrição de um campo de arroz, segundo Seu Silvério:

É bonito, né. Ver o arroz todinho amarelinho, né ... Quando os cacho está tudo virado, né, cê chega assim tá tudo amarelinho. [...] passava assim na beira da estrada e fica oiando aquele arroz todo com as foias tudo amarela e com os cachinho amarelo e ficava mostrando pra turma, óia gente, óia o arroz aí, e os menino que não conhece, né, aí o mulecada aquilo que é arroz, é. (Entrevistado pela autora, janeiro/2004)

Conforme Marvin Harris ${ }^{167}$, na obra de Wanderley (1999, p.9):

(...) a relação ideal do homem da cidade com a terra é a que supõe meeiros entre ele e o solo. O ideal do homem do campo é de dispor de terra e água suficientes para alimentar sua família. $\mathrm{O}$ urbano sonha em ficar rico com o solo; o rural sonha com a plantação.

A beleza da vida é buscada nas coisas do campo - que aparecem valorizadas conforme os relatos. $O$ encanto de semear e colher, acompanhar o crescimento, a valorização do alimento fresco, disponível, saudável, fruto do trabalho pode ser apropriado por quem o produziu, sem cisão. A sensação, segundo relatos, é de orgulho e plenitude dentro desse processo. $O$ trabalho rural ${ }^{168}$, em todas as suas dimensões, não aparece como algo que não lhes pertence; tem materialidade, se aproxima do Labour e se contrapõe ao trabalho abstrato, esvaziado de significação. E, conforme Maia (1994), esse trabalho rural encerra atividades desempenhadas

\footnotetext{
${ }^{167}$ HARRIS, Marvin. Town and country in Brazil; a socio-anthropological study of a small Brazilian town. New York, Northon \& Company, 1956. 304 p.

${ }_{168}$ Mescla o sofrimento do trabalho árduo e ao mesmo tempo o prazer, a realização plena que proporciona. O trabalho representa um valor ético.
} 
com identificação e com o domínio do saber, não estranhas ao homem, envolvendo também o prazer, o lúdico.

O que se busca é um modo de ser simples, uma sociabilidade do homem simples, um viver pleno de significados, com base no uso enquanto valor. E o uso guarda a dimensão da vida, sendo fundado no costume, propondo formas de apropriação diferenciadas. Portanto, ocupar um espaço para a produção de uma horta ou criar animais traz para esses migrantes o sentido do uso, um resgate de valores ou a sua perpetuação (mesmo resignificados) e sua afirmação enquanto sujeito social numa nova realidade. Ao mesmo tempo, podemos falar também no desejo de apropriação da cidade. Esse desejo vai além das necessidades, já que é caracterizado pela pulsão (LEFEBVRE, 1980), expressa a vontade de estar no campo dentro da cidade, de reviver experiências da vida passada, desejar ter o que se tinha.

Muitos falam da vontade em ter um sítio ${ }^{169}$ onde pudessem plantar e ter animais, mas não têm condições - é o desejo refreado, retido, e como o autor citado coloca: o desejo acaba sobrevivendo como mal-estar, como espera - atravessado pela cotidianidade organizada. O migrante vive o conflito de querer viver no campo e na cidade ao mesmo tempo, "querem ser da cidade, mas não querem perder o vínculo com o campo", segundo Ariovaldo Umbelino de Oliveira (informação verbal). Os nossos entrevistados dizem gostar de Cubatão, pois é a cidade que os acolheu, onde conseguiram obter o que têm hoje. É a terra que lhes deu o pão e o acesso a bens, considerando as novas necessidades que o capital cria, disponibiliza e ao mesmo tempo não permite ter.

A experiência de vida no campo destaca uma ordem moral com base na ética camponesa, onde a vida é marcada por um outro ritmo, pelas relações sociais fortemente regidas pela ordem próxima, pelo respeito, pela reciprocidade. São outros valores, que se colocam conforme o relato que segue:

Porque a maioria do pessoal até hoje memo lá a turma só pranta pra comer só um tempo, aí pra completar o ano, aí compra. É difícil porque também você pranta e difícil tirar tudo que gasta, e cê acaba

\footnotetext{
169 No trabalho de Durhan (1978), esse desejo aparece expresso na fala de um entrevistado, que o justifica dizendo que seu primeiro viver foi na roça.
} 
prantando, pagando mais caro do que comprando. Se vai, se caba pagando o dobro e for o caso de comprar direto, mas se tudo mundo for pensar assim, vai todo mundo só comprar, só comprar, fica mais difícil, né, morar na roça e não cuidar da roça não tem... não tem condição. (Entrevistado pela autora, janeiro/2004)

Mesmo diante das dificuldades, a independência e a liberdade são valorizadas. A organização da produção camponesa é feita a partir de uma "economia de excedentes", onde o excedente não é o resto ou a sobra. Produz-se para a subsistência e também para troca, isso envolve um raciocínio. No caso do assalariado do campo ou o operário, seus montantes são mediados pelo capital, sendo a materialização de trabalho abstrato, que é social. A quantidade da produção que vai se constituir no meio de vida desse trabalhador assalariado é calculada pela mediação do capital. (MARTINS, 1997).

Conforme relatos, a ética camponesa é contraposta ao modo de vida urbano. Porém, apesar de tudo que o campo representa, a cidade é o local das possibilidades. Ela abriga estruturas importantes, e embora o acesso a elas possa ser questionado, elas estão, de certa forma, disponíveis. Perguntado sobre o retorno ao campo, um entrevistado respondeu:

Ah não, tenho medo de ir pra lá e ver essa vida aí, precisar de um médico... Apesar de que aqui também se a gente precisar assim com urgência, não tem convênio nem nada, né, sempre tem essas dificuldades, né. Vai pro pronto socorro, fica lá mofando horas, horas, horas... Mas sei lá, não sei se é ilusão da'gente acho que si eu for pra lá a dificuldade é muito mais. (Entrevistado pela autora, janeiro/2004)

As relações sociais vivenciadas no campo sempre são recordadas e comparadas com as novas relações estabelecidas na cidade.

Fica recordano, né, as outra pessoa, o modo como eles tratava a gente, a gente tratava eles, né, o respeito que tinha pela gente. As veiz tinha a hora que eles tinham também as brincadeira deles, né, as veiz ria da'gente também brincando ali, punha apelido, né... Mas aqui também tem, né, sempre bota apelido um no outro, lá também sempre põe apelido, e a gente sente falta, né, das casa, a gente 
chegava nas casa sempre, a gente ia na casa lá o que mais eles enchia a gente era de café, era café... Se você ia em dez casa tinha que tomar café em dez casa. Ah não quer tomar o meu café, né, tomou de fulano, não quer tomar o meu! Aí tinha que tomar o café. A gente saia, quem tinha poblema de azia saia, né, igual dragão (risos) soltando fumaça pra fora, é, então tem aquela saudade, né, das região que a gente passava. (Entrevistado pela autora, janeiro/2004).

As lembranças de uma outra sociabilidade sempre permanecem. Na cidade, novas relações são construídas com base nos valores da ética camponesa, na campesinidade desses sujeitos sociais. A família restrita e extensa é vista como valor, permanente no tempo. Ela desempenha um papel importante na vida do migrante, assim como a terra é a expressão de uma moralidade (e não como objeto de trabalho). A migração é, na maioria das vezes, viabilizada pela família, conforme discutimos em outro capítulo do presente trabalho. Por isso, a migração tem um caráter familial, segundo Durhan (1978). As redes de parentesco e conhecimento são instrumentos importantes no processo migratório, garantem a chegada, a adaptação e a permanência dos migrantes nos locais de destino. Conforme relatos, a sociabilidade antiga sempre é buscada através das novas relações com a família próxima e com os amigos e vizinhos. Para Durhan (1978, p. 26) "as formas de relação interpessoal se mantêm mesmo quando são destruídas as bases territoriais".

A cultura ${ }^{170}$ camponesa, expressa através de práticas sociais, é reconhecida como traço marcante na população cubatense. A vocação da cidade para a ruralidade é associada ao fato do município abrigar uma grande quantidade de migrantes oriundos do campo. Segundo nossos entrevistados, Cubatão é uma cidade que tem uma "cultura nortista" e que o nortista gosta "dessas coisas ${ }^{171}$ e isso deve ser respeitado, pois é a essência do povo que veio trabalhar na indústria”. Cubatão, na perspectiva de muitos entrevistados, é uma cidade industrial, mas com um "povo nordestino". Para os entrevistados, "povo nordestino" significa as pessoas que vieram do Nordeste e que têm uma cultura diferente, modos de ser diferentes, e que

\footnotetext{
170 Para Woortmann (1990, p. 23), a cultura é o "universo de representações de um grupo, categoria ou sociedade e também um conjunto de textos ou discursos... Um sistema onde diferentes núcleos de representações estão em comunicação uns com os outros, como que formando uma rede de significados".

${ }^{171} \mathrm{O}$ entrevistado se refere ao desejo de plantar e de ter um animal. Mas esse pensamento também abrange a ordem dos valores, da ética camponesa.
} 
na maioria das vezes exprimem campesinidade e/ou uma raiz camponesa. Alguns entrevistados expressam a necessidade de uma convivência harmoniosa entre elementos rurais e urbanos no contexto urbano, alegando que o poder público deve assumir essa diversidade da realidade social que se impõe.

Muitos salientam que "Cubatão não respeita a cultura do povo"; que "o trabalhador da terra é muito perseguido pela política do município que não dá condições para que as pessoas vivam da terra, obrigando as pessoas a saírem para outros municípios". As atividades agropecuárias no contexto urbano, ou seja, a proposta de agricultura urbana é tratada por alguns entrevistados não só como uma forma de restabelecer laços da cultura camponesa, mas também é como uma proposta alternativa de atividade econômica ao município. Essa perspectiva denuncia a falta de uma estrutura ampla que atenda às necessidades dessa população, como por exemplo:

- A delimitação de uma Zona Rural e o reconhecimento de alguns subespaços rurais;

- Estruturas físicas que permitam o pleno desenvolvimento das atividades agrícolas, como a instalação de um abatedouro e de uma Casa da Agricultura ${ }^{172}$;

- Incentivos para a agricultura urbana como insumos, cursos, apoio técnico, entre outros;

- Delimitação de uma área onde os cavalos possam permanecer na cidade.

As reivindicações são várias, havendo vários tipos de conflitos com o poder público $^{173}$ em relação a essas práticas rurais - que na verdade são reveladoras da situação de marginalização da população, que busca uma inserção social não só no que se refere ao reconhecimento de direitos, mas também a todas as dimensões que consideram fazer parte de uma vida plena. A cidade colocaria, então, limites no

\footnotetext{
172 Muitos reclamaram que comparam rações em lojas que vendem produtos para aves, mas que precisam ir a outras cidades para adquirir vacinas, remédios, insumos e ferramentas, entre outros. Em uma entrevista, percebemos que o entrevistado apreende as contradições do poder público, que defende o meio ambiente de forma fragmentada e distorcida, estabelecendo usos determinados conforme a racionalidade do capital.

${ }^{173} \mathrm{O}$ conflito também se dá através de ameaças de desapropriação e tomada de terras de alguns sitiantes. A ameaça parte tanto de órgãos públicos quanto de pessoas que se dizem proprietárias das referidas terras.
} 
atendimento às necessidades apresentadas, negando sua identidade camponesa, reconhecendo somente sua identidade industrial, apoiando a expansão e a reprodução do capital. Por outro lado, ela demonstra certa tolerância com tais atividades ${ }^{174}$. Na visão dos entrevistados, o conflito estaria na falta de leis que apóiam o cidadão ou na vigência de outras que causam impedimento dessas atividades. Caberia então à Câmara Municipal executar mudanças nessas leis.

Segundo os entrevistados, o prefeito apóia, mas as leis impedem. Há, portanto, um descompasso entre as relações sociais estabelecidas entre os detentores do poder e os instrumentos utilizados pelos mesmos, ou seja, uma combinação entre a ordem próxima e a ordem distante nesse processo. Na verdade, não existe um apoio da Prefeitura a essas atividades, o prefeito, por sua vez é que expressa certa simpatia, um exemplo disso é a participação permitida de cavaleiros em desfiles cívicos.

$\mathrm{Na}$ cidade, o trabalho assalariado passa a ser um mero "instrumento para a satisfação das necessidades e não como atividade satisfatória em si". (DURHAN, 1978, p. 180). Quando o trabalho tem seu significado esvaziado (trabalho abstrato que forma o trabalho sem conteúdo), a tendência é a busca externa desse significado. A partir dessa reflexão podemos interpretar também um dos sentidos das hortas, e da criação dos animais na cidade.

A idéia de felicidade é expressa, muitas vezes, através da realização de atividades que remetem ao universo rural. Seu João ilustra bem isso quando menciona as brincadeiras, envolvendo os familiares dos donos de cavalos, realizadas nos finais de semana como as provas de tambor e as cavalgadas. Segundo ele, "é coisinhas pequena, mas é coisas pequena que eles se alegram!". Lembramos o que José de Souza Martins (1998) fala sobre a reinvenção da alegria, como um artifício usado por aqueles que vivem a situação de constante exclusão e miséria, e tentam criar o sentido da alegria. A excludência seria utilizada como desafio de criatividade e resistência, conforme Martins. Ainda nesse sentido, podemos dizer que a tendência desse sujeito social é expandir seu aparato simbólico na direção e em busca de um sistema maior, capaz de explicar e dar sentido aos inevitáveis impasses da sua vida. (MAGNANI, 2003). A alegria é buscada nos elementos que remetem à sua raiz, aos

\footnotetext{
${ }^{174}$ Por trás dessa tolerância, aparecem vários interesses, que são usados para estabelecer o controle social e desobrigar o poder público de algumas tarefas de manutenção de áreas públicas e de lazer.
} 
atributos do campo, às atividades rurais. Podemos dizer que a apropriação da cidade é feita com base na campesinidade desses indivíduos, a partir da lógica do uso.

Em Cubatão, a criação de animais para abate, segundo relatos, ocorre desde a década de 1970. Na cidade existe um mercado consumidor para esse tipo de alimento, porém, diante das restrições impostas ${ }^{175}$ à criação e ao consumo, os criadores sobrevivem na clandestinidade. Antes da proibição, a sociedade civil chegou a criar em 1992 uma "Associação de Criadores e Abatedores de Carne Suína, Bovina de Cubatão ${ }^{176 ", ~ n o ~ e n t a n t o ~ n e m ~ t o d o s ~ o s ~ c r i a d o r e s ~ s e ~ a s s o c i a r a m . ~}$ Alguns resolveram ir para cidades vizinhas, como São Vicente e Guarujá, que fazem limite com Cubatão, em locais próximos ao município. Assim, criam os animais, abatendo-os por lá, mas voltam a Cubatão para vender as carnes. Outros permanecem em Cubatão.

Muitos exercem essa atividade porque sobrevivem dela, porém outros criam para consumo próprio e dizem que o fazem por prazer. Para um entrevistado esses impasses ficaram sempre "no limite", foi então que os cavalos começaram a surgir em grande quantidade, embora já existissem em pequeno número. Em alguns relatos identificamos alusões à história de Cubatão, destacando as origens rurais do município. Alguns entrevistados se valem desse passado como justificativa para as atuais práticas agrícolas existentes na cidade, vistas como continuidade que precisa ser aceita pelo poder público. Novamente se coloca a questão da cultura camponesa na cidade.

Enquanto a criação de animais era uma atividade de caráter mais econômico, garantindo também a subsistência, também representava uma dimensão da ordem moral dessas pessoas. Porém, a criação de cavalos aparece totalmente desvinculada do caráter econômico; as pessoas criam por prazer, pois alegam que isso vem de suas raízes, conforme o relato que segue:

Porque o nordestino, ele vem de lá, é um vaqueiro... Ele trabalhava como vaqueiro. Então qual era a vida dele? Era no fim de semana

\footnotetext{
${ }^{175}$ Ação da prefeitura juntamente com a Vigilância Sanitária.

${ }^{176}$ Nem todos os criadores aderiram a essa Associação.
} 
estar montado num cavalo, ir para as festas, ir para a vaquejada, né?! Então a finalidade do cavalo era esta. (Entrevistado pela autora, junho/2006).

Mesmo não tendo condições ${ }^{177}$ de manter um animal, eles ainda assim, o fazem, desafiando também o poder público e a Vigilância Sanitária que proíbem a circulação e criação de animais de grande porte no perímetro urbano. Vale lembrar que a existência de cavalos na cidade é anterior à proibição. Alguns criadores deixam seus animais em sítios, ou até mesmo soltos, no Vale dos Pilões, mas a grande maioria não tem onde deixá-los. É comum ver cavalos espalhados por toda a cidade, pastando.

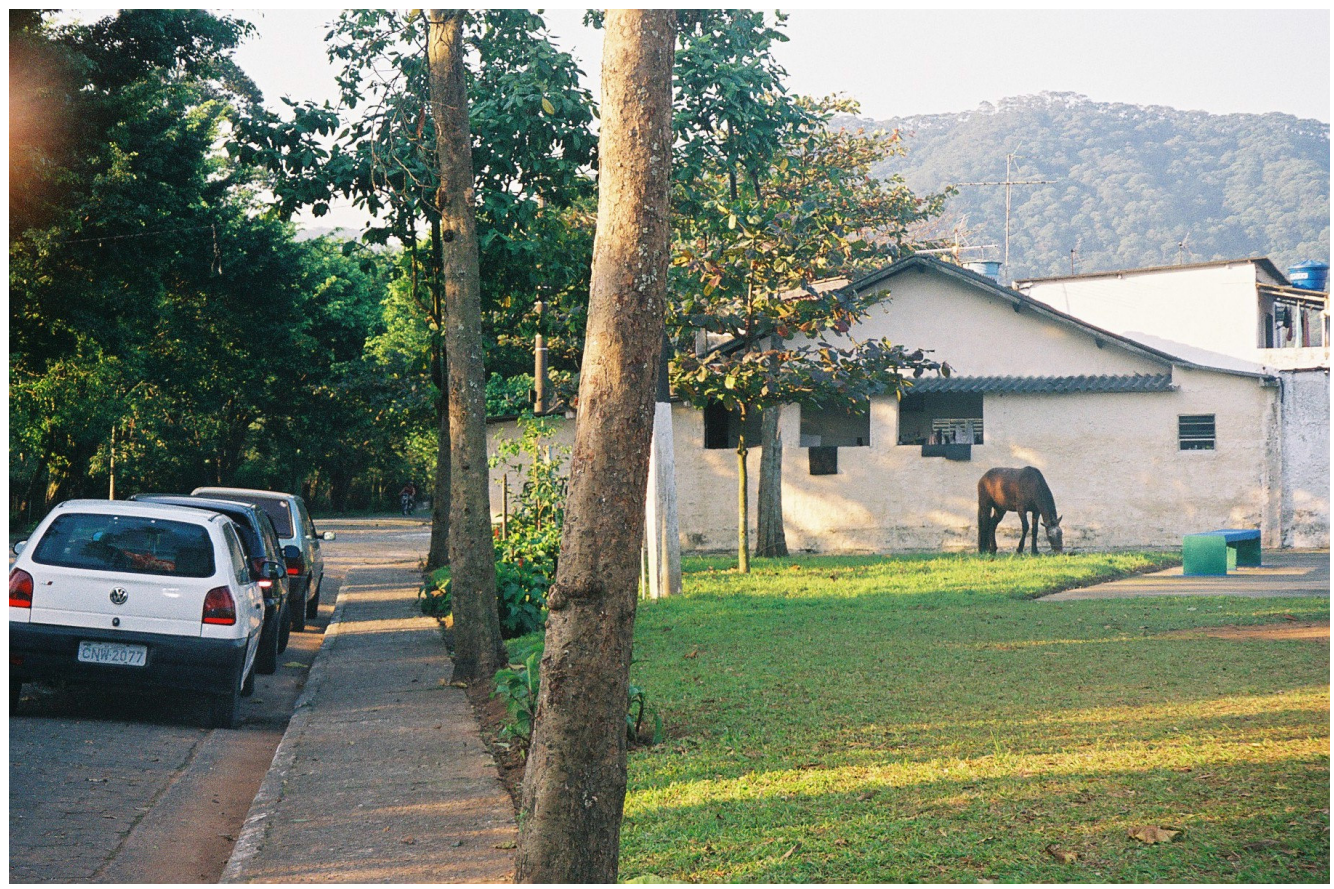

Figura 27: Cavalo pastando em local público no Jardim Costa e Silva. (Data: agosto/2006) Fonte: Foto Vilma Aparecida da Silva

A apropriação do espaço obedece aqui à lógica do uso, conforme os fatos demonstram. Mesmo que os cavalos permanecessem em sítios nos Pilões, ainda assim, seus donos estariam desobedecendo à "lei", já que não existe um espaço onde as atividades agrárias sejam permitidas. Portanto, eles chegam à conclusão de que tanto faz esses animais estarem num sítio ou não, pois a situação de

${ }^{177}$ Até devido ao espaço que não dispõem. 
irregularidade permanecerá. Surgem então alguns conflitos com o poder público que, ora penaliza ora tolera essa atividade, permitindo apresentações de grupos de cavaleiros em desfiles cívicos, conforme vemos na foto que segue:

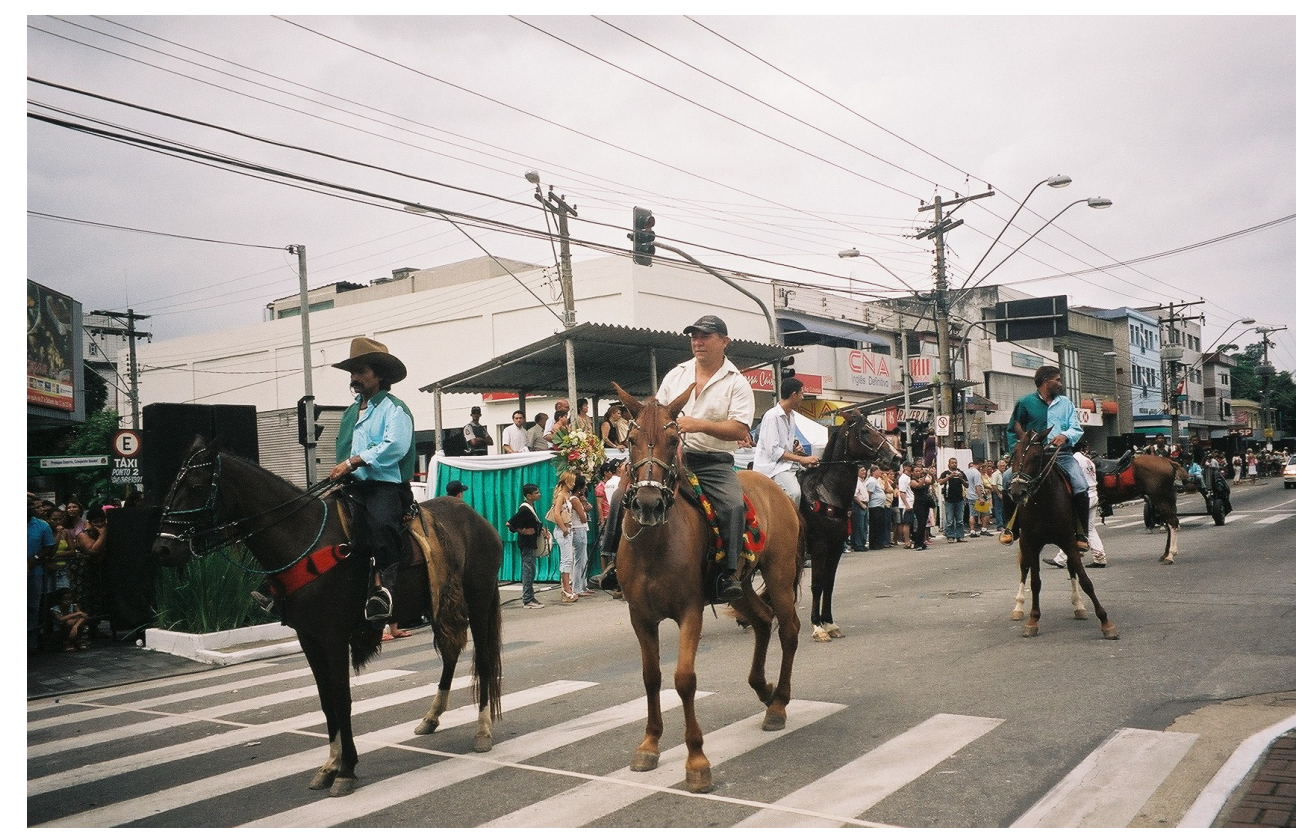

Figura 28: Em primeiro plano, observamos os cavaleiros e seus cavalos na Avenida Nove de Abril em desfile cívico, tendo ao fundo o palanque ocupado pelas autoridades locais. (Data: 09/04/06)

Fonte: Foto Vilma Aparecida da Silva

Em 1995, alguns cavaleiros se reuniram e fundaram a "Associação da União dos Cavaleiros de Cubatão". A partir dessa data, eles começaram a organizar atividades lúdicas na cidade, como festas em bairros, apresentações, cavalgadas e torneios. A Associação também tenta resolver os problemas envolvendo os cavalos, como por exemplo, a apreensão dos animais (vide Anexo B). No entanto, suas atividades não são totalmente reconhecidas por uma parte da população que as considera inadequadas ao contexto urbano.

O lazer poderia ser definido como um conceito criado pela sociedade do trabalho, sendo uma atividade organizada. Porém, as atividades realizadas envolvendo a comunidade, cavalos e cavaleiros em Cubatão, estão mais próximas de um caráter lúdico, uma vez que elas não deixam de ser uma manifestação cultural, trazendo a essência da Festa, a espontaneidade. Essas atividades, das quais participam alguns cavaleiros, se estendem a outras cidades, como Peruíbe, Monguaguá e Pedro de Toledo, entre outras. Nessas cidades, os criadores de animais e cavaleiros dizem se 
reunir freqüentemente para realizarem provas e rodeios. Eles se referem a elas como "brincadeiras". Observamos, portanto, uma expansão dessas relações sociais a outros locais de encontro, onde estão "entre iguais... Num lugar impregnado pelo aspecto simbólico que os une". (MAGNANI, 2000).

O significado do lazer vai além de uma definição restrita da reprodução da força de trabalho. Podemos observar que:

O lazer é, também, uma conquista. Nos espaços periféricos, mais populares, o caráter de conquista dos lugares de lazer é evidente. Dramática e coletivamente eles são conquistados, sendo expressões da identidade irredutível dos espaços empobrecidos, da ação solidária de homens, mulheres e, mesmo das crianças. Mais do que tempos e espaços industrializados, frutos da ampliação do mundo da mercadoria no universo do tempo livre, o lazer ainda é residual às lógicas sociais, que reproduzem a sociedade existente, a das empresas e do Estado. Constitui o espaço e o tempo primordiais da vida urbana mais plena. (DAMIANI, 1997, p. 50).

Os locais das festas podem ser tomados como espaços do desejo, onde o resíduo se manifesta. A apropriação da cidade também passa por aí. As festas estão próximas de um contexto original vivenciado, que é resignificado durante o processo, promovem o encontro, estabelecem laços e expressam, também, o conflito do cotidiano da cidade, sendo atravessadas pela cotidianidade, mas também propõem um exercício da criatividade, o novo. Elas são esperadas, celebradas e comentadas. É o contraponto do trabalho, uma tentativa de restituir a Festa, transformando o cotidiano, reinventando a alegria.

$\mathrm{Na}$ cidade, muitas festas populares (temáticas) também são organizadas pela Prefeitura do Município de Cubatão, e seus temas quase sempre remetem à cultura nordestina. (vide Anexo A)

As manifestações da campesinidade no espaço urbano são pertinentes na análise das relações campo-cidade, na medida em que demonstram a relação intensa entre urbanidade e ruralidade. Além de que “(...) Essas 'sobrevivências' sugerem, no mínimo, cautela em relação com certas correntes teóricas que atribuem à cidade e à 
fábrica um poder de corrosão das culturas tradicionais que não está se confirmando na intensidade suposta." (MARTINS, 1993b, p. 26).

\subsection{Sítio Capivari}

Muitos de nossos entrevistados moram em bairros próximos ao centro da cidade e exercem atividades de criação de animais ou plantio em outras áreas do município. Eles se deslocam a pé, de ônibus ou a cavalo. Ainda que o fato não signifique uma vida voltada inteiramente aos cuidados do campo, representa um fenômeno pertinente. Uma mescla de modos de vida, de vivência cotidiana no meio urbano que merece atenção. Na realidade é a problemática urbana que se impõe.

Os deslocamentos constantes para a área de plantio são uma tarefa difícil, uma vez que o indivíduo precisa se submeter a meios de transporte ou exercer esforço físico, e que também envolve outros fatores, muitas vezes o deslocamento se faz com utensílios de trabalho e insumos, entre outros, o que não inibe a movimentação dessas pessoas. Presenciamos jovens, crianças e adolescentes realizando esses percursos. Como é o caso de Seu Luís (A), que vive de suas colméias em um sítio nos Pilões, mora na Vila Nova (um bairro muito próximo ao centro da cidade) e ainda auxilia o Corpo de Bombeiros ${ }^{178}$ de Cubatão em casos que envolvem abelhas.

Perguntado sobre suas atividades ele responde que tem prazer em realizá-las, e que não é sacrifício algum. Ele não se importa de se deslocar com sua bicicleta, carregando uma caixa de colméia, e gosta de ir aos Pilões e estar em contato com a Natureza ao mesmo tempo em que providencia seu sustento ${ }^{179}$.

\footnotetext{
178 Segundo os cabos e Capitão da Equipe "Prontidão Azul" (que estava de plantão quando realizamos a entrevista), Seu Luís (A) auxilia o Corpo de Bombeiros em $90 \%$ dos casos.

${ }^{179}$ Seu Luís $(A)$ vende mel de abelhas.
} 
Próximo ao Parque Anilinas, localizado na Avenida 9 de Abril, no centro da cidade, continuando pela linha de trem ou fazendo mais uma curva ao final da rua, logo encontramos uma entrada de terra. A 100 metros dali chegamos ao sítio da família de Seu Luiz $(B)^{180}$.

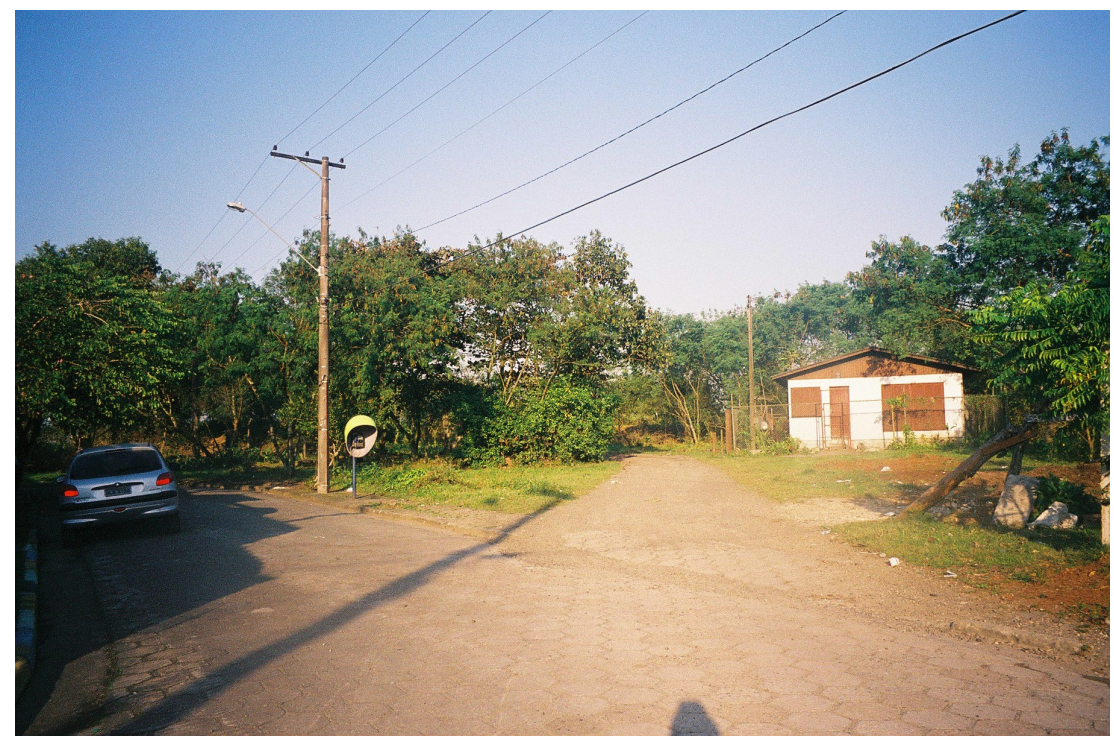

Figura 29: Entrada do Sítio Capivari localizada no Conjunto Residencial Afonso Schmidt. (Data: agosto/2006)

Fonte: Foto Vilma Aparecida da Silva

Para chegarmos ao sítio, passamos por debaixo da linha do trem, que nesse trecho atravessa o Rio Cubatão. Quando chove muito, a passagem enche, restando a opção de cruzar a linha de trem mais à direita. Lá no sítio, às margens do rio, encontramos o local de trabalho de Seu Luiz (B): uma cobertura, onde ele fabrica ferradura e ferra os cavalos da região. Ele tem clientes de longe que apreciam seu trabalho. O entrevistado conta que antes ferrava uma média de oito cavalos por dia, mas hoje a temporada está baixa, e por isso ferra de cinco a seis cavalos por dia.

Seu Luiz (B) conta que, de três anos pra cá, o movimento caiu. Ele atribui a diminuição à proibição de animais na cidade feita pela Prefeitura e pela Vigilância Sanitária. Muitas pessoas, segundo ele, venderam seus animais e deixaram de

\footnotetext{
${ }^{180}$ Seu Luiz (B), ao se casar, mudou-se para o Conjunto Habitacional Mário Covas, próximo às hortas do projeto piloto da Vila Natal.
} 
adquirirem novos. A Associação dos Cavaleiros auxiliou na administração da questão, no entanto surgiram outros impasses, como por exemplo, a adesão às novas regras da Associação, como pontualidade e pagamento de uma taxa de $\mathrm{R} \$ 10,00$ por associado. O número de associados, segundo Eraldo (presidente da Associação dos Cavaleiros de Cubatão) deveria ficar em torno de cinqüenta, porém, é de apenas quinze e explica:

E: "Olha, era para nós estar hoje com uma base de cinqüenta e pouco sócios. Só que, infelizmente, tem o estatuto, né? E tudo você tem que ter uma disciplina. Então, o estatuto diz o seguinte: como tem uma mensalidade tal, o pessoal tem // Então, se você parar de pagar a mensalidade por três meses consecutivos, a gente entende que você se desligou. Então, muitos aconteceu isso. Por que aconteceu isso? Justamente porque a prefeitura, quando estou falando que tem uma lei que proíbe, muitos venderam. Então hoje estamos com uma base de quinze associados.

V: Só?

E: Só. Porque esses ainda têm aonde guardar os animais". (entrevistado pela autora, junho/2006)

As entradas e saídas de sócios pertencentes à Associação dos Cavaleiros são grandes. Se por um lado, a Associação ainda consegue administrar os conflitos oriundos da existência de animais na cidade, por outro suscita questões para seus donos, uma vez que eles precisam interagir com novos códigos sociais. Isso gera incompreensão e discordância em relação aos novos valores. Alguns sócios são convencidos e aceitam, internalizando as regras impostas, outros, quando possível, discordam e pedem esclarecimentos, buscando um consenso. Mas há aqueles que sentem certo desconforto com a nova situação proposta e se desligam, ou que simplesmente se afastam quando se sentem desfavorecidos, e se associam novamente ao sentirem necessidade.

Independente das regras da Associação, a posse de um animal requer gastos, e para uma população que carece de grandes recursos, como é o caso da população cubatense, a situação se complica. Por isso, a solução muitas vezes é encontrada 
na venda do animal, postergando uma nova aquisição a tempos mais favoráveis financeiramente, como observamos na fala de um entrevistado:

Eu, particularmente, estou até pensando em ceder o meu cavalo. Como o meu cavalo, ele não é caro, mas aqui no Cubatão ele se torna caro, eu estou pedindo pelo meu cavalo dois mil reais. É um cavalo que vale até três. Mas, como aqui em Cubatão a maioria do pessoal, como eu estava falando para você, é humilde, são pessoas humildes, 'dessalariadas', não tem condições. Então a maioria é cavalo de quinhentos reais, oitocentos reais. Então como eu estou tendo esse problema, não estou mais usando o cavalo, não estou mais brincando com o cavalo e ele se torna caro para mim, porque eu tenho um gasto mensal com ele. (Entrevistado pela autora, junho/2006)

O próprio Seu Luiz (B) salienta que, na Vila São José, havia quinze cavalos, mas que hoje, só podemos encontrar um cavalo; enquanto no Bairro Pilões, havia 30 cavalos. Segundo o entrevistado, o gasto com ferradura é de aproximadamente $\mathrm{R} \$ 25,00$ (vinte e cinco reais) por mês, e se o cavalo andar muito, precisa ser ferrado a cada cinco dias, o que eleva o gasto mensal com a ferração, sem contar as despesas com alimentação e cuidados veterinários, conforme relata um entrevistado:

A cada quinze dias eu levo ração, levo farelo de trigo, se precisar da veterinária eu levo ele para o veterinário, faço tudo que ele precisa: os exames dele, fezes, sangue, tudo ele tem, carteirinha, tudo isso ele tem. (...) Também é sagrado, meu sábado eu levanto, tomo banho, tomo meu café, pego meu pacote de cenoura, vou levar lá para ele ${ }^{181}$. (Entrevistado pela autora, junho/2006)

No sítio vivem três famílias, todos parentes de Seu Luiz (B): irmão, irmã e pais (Seu Antônio e Dona Graciliana). Ao fundo da cobertura de madeira e telhas de barro, avistamos um campo amplo, onde o gado pasta um pouco e onde também fica o cocho para alimentar os animais (cinco bois e onze vacas).

\footnotetext{
${ }^{181}$ Entrevistado pela autora. O senhor entrevistado paga mensalmente para Seu Luiz (B) cuidar de seu cavalo, no sítio do próprio Seu Luiz (B).
} 


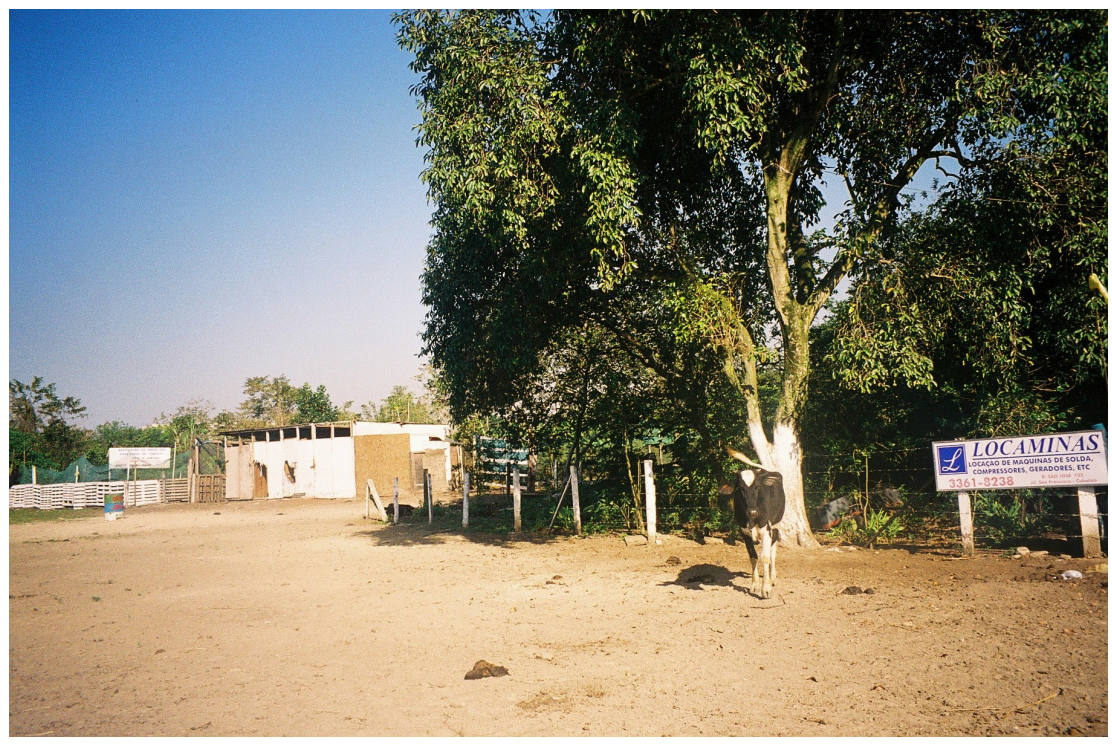

Figura 30: Área reservada para os animais no sítio Capivari.

(Data: agosto/2006)

Fonte: Foto Vilma Aparecida da Silva

Como o terreno não é muito grande, é fácil encontrarmos bois e cavalos pastando próximo à entrada do sítio. Seu Luiz (B) também cria porcos para vender (são trinta porcos atualmente), mas eles ficam em um terreno na Alemoa - no caminho para a cidade de Santos $^{182}$. O resto é uma pequena lavoura. Eles plantam mandioca, milho e batata-doce, além de outras culturas, como verduras.

O capim para alimentar os cavalos $^{183}$ vem da região do Rio Perequê, ou, às vezes, até de Santos, e a complementação alimentar é feita com ração. Para ir até o rio, eles utilizam, muitas vezes, o barco. Segundo o entrevistado, sua renda vem da ferração dos cavalos e da criação dos porcos, que ele vende vivos e podem ser comercializados com um ano de idade, sendo que, aos seis meses, cada um deles já pesa cinqüenta quilos. Seu Luiz (B) os vende na feira, para alguém que deseje fazer uma "festinha", "essas coisas assim", acrescenta.

\footnotetext{
182 Durante o nosso trabalho de campo encontramos algumas pessoas residentes na Alemoa, em Santos. O local também é conhecido como Vila dos Criadores, por ter uma quantidade significativa de pessoas que criam animais. Num domingo ensolarado encontramos duas charretes na Avenida 9 de abril indo em direção ao Parque do Perequê. Segundo as pessoas que estavam nas charretes, elas residem na Vila dos Criadores, mas estão ligadas ao município de Cubatão por laços de amizades e lazer. O Parque do Rio Perequê recebe turistas e moradores da cidade, que vão lá a procura de lazer, e banhar-se nas águas do rio e nas cachoeiras. Muitos fazem piqueniques no parque. O parque também tem se tornado um local de encontro para os criadores de cavalos e outros animais, que aproveitam o fim de semana para passear com a família no local.

${ }^{183}$ São 5 cavalos, sendo 3 pertencentes a Seu Luiz (B) e outros 2 de seu sobrinho Edson.
} 
Os irmãos e o pai de Seu Luiz (B) são pescadores, seus barcos ficam em frente às casas, no sítio. A mãe cria galinhas, umas cem. Segundo o entrevistado, a mãe conhece todas. Seu Luiz (B) conta que a mãe muitas vezes comenta: "Sabe, Luiz, aquela galinha tal anda sumida..." e ele responde: "Mas mãe, como é que a senhora quer que eu lembre disso? Eu sei lá que galinha é essa?". Dona Graciliana vende os ovos e as galinhas, o resto é para o sustento da família.

Os irmãos de Seu Luiz (B) trabalharam na Refinaria Presidente Bernardes, na Cosipa, e como seguranças de Banco, mas agora se dedicam apenas à pesca. A maior produção é de Tainha, robalo, carapeba, camarão sete barbas e caranguejo, que eles vendem nas ruas de Cubatão.

O cavalo de Edson (sobrinho de Seu Luiz (B)), é um cavalo marchador ${ }^{184}$, ele participa de eventos na cidade, como desfiles, festas e apresentação de rodeios. Edson também utiliza sua charrete para fazer propaganda pela cidade, ele instalou um aparelho de som na charrete ${ }^{185}$ e cobra para passar "cd's" com propaganda, recebendo por semana. Ele também trabalha com seu tio Luiz na ferração dos cavalos, segundo ele, seu cavalo fica com as ferraduras em dia. Ele ajuda o tio desde pequeno, e diz gostar muito disso.

O sítio onde Seu Luiz (B) mora pertence a Seu Antônio Mendes, que mora em Santos e só aparece a cada dois ou três anos para fazer uma visita. A família de Seu Luiz (B) mora nessas terras há 25 anos. Seu pai tornou-se caseiro do lugar, após trabalhar na indústria, assim que chegou de Pernambuco - de onde veio atrás de serviço em Cubatão. Segundo Seu Luiz (B), eles não são proprietários, mas têm acesso à terra, e isso ele valoriza.

Seu Luiz (B) nasceu em Cubatão, numa llha no rio Cubatão, próxima à Cosipa. Ele aprendeu a ferrar cavalo sozinho, e depois buscou se aperfeiçoar, adquirindo mais

\footnotetext{
${ }^{184}$ Segundo Edson, o cavalo é um "pangaré com argentino", e para ele nunca pode faltar ração. Ele também tem um pangaré, esse é mais resistente, pode comer só capim que não morre, segundo o entrevistado.

${ }^{185}$ Quando perguntado sobre o surgimento da idéia do som na charrete, Edson respondeu que viu uma charrete em São Vicente, na Baixada Santista, com o som e gostou. Em Praia Grande, também na Baixada Santista, segundo Edson, há muitas charretes deste tipo. No entanto, ele faz questão de afirmar que, em Cubatão, apenas a sua tem esses acessórios. A charrete tem pneu de moto e rolamentos de carro. Ele adquiriu o som nas Casas Bahia.
} 
conhecimentos com um ferrador conhecido. Ele reclama que o movimento caiu de três anos pra cá.

O longo período na situação de caseiro, na qual vive grande parte da família de Seu Luiz (B), revela uma relação de confiança do dono do terreno para com essa família. Ou talvez uma despreocupação, ou desinteresse, do proprietário pela terra.

O uso que eles fazem desse espaço é rural. Tanto no que concerne à atividade da pesca e da agricultura, e mesmo quanto ao trabalho desempenhado com a ferração de cavalos. Estendendo-se ainda a outro espaço, como é o caso da criação de porcos na Alemoa. A relação com a cidade de Cubatão é uma relação rural. Mesmo diante da impossibilidade de serem absorvidos por empregos na indústria, não podemos encobrir a opção clara pelas tarefas acima citadas. Percebemos uma satisfação, uma realização grande no exercício dessas tarefas, na lida com a terra, com os animais e principalmente com o rio, de onde também tiram seu sustento.

No entanto, eles reclamam por falta de apoio por parte do poder público. A criação de porcos poderia se realizar no sítio, mas, infelizmente, por determinação da Vigilância Sanitária, ela foi proibida ${ }^{186}$. Percebemos, durante nossa pesquisa de campo, um conflito latente na cidade quanto a essa situação. As pessoas que tem criações de animais sofrem com a falta de alternativas. Embora muitas delas realizem a atividade como única fonte de renda, muitas também gostam de criar animais para o consumo próprio.

Há um mercado velado de carnes na cidade. Mesmo sem adquirir o produto nas feiras livres, os moradores procuram obtê-lo por outros meios: indo até a casa do criador ou pedindo a alguém que conhece quem cria. O que verificamos foi uma teia envolvendo essas atividades, que não se esgotam apenas no comércio de carnes, mas também que se estendem a outras relações. Há a criação de uma sociabilidade; as pessoas que criam e plantam, comercializam, se articulam e estabelecem laços de amizades. As pessoas que compram também fazem suas

\footnotetext{
${ }^{186}$ Seu Luiz (B) nos relatou um fato interessante em relação a isso. Ele disse que foi requisitado por uma veterinária para vacinar alguns animais, porque a mesma tinha medo. Os criadores de porcos vendiam as carnes na feira da cidade, alegando falta de vacinação, a Vigilância Sanitária proibiu sua comercialização. Então, a prefeitura deu um prazo de 6 a 7 meses para que eles encerrassem as criações de porcos, em seguida a Vigilância deu mais trinta dias, seguidos de outros trinta.
} 
amizades, tanto com os criadores quanto com apreciadores das iguarias. Além do porco, são consumidos bodes, cabritos, boi, galinhas, ovos e patos.

Sabemos que tanto o espaço rural quanto o espaço urbano apresentam formas e conteúdos específicos, porém não há uma homogeneização; encontramos elementos diversos dentro da complexidade desses espaços. Assim como o sítio de Seu Luiz (B), encontramos outros espaços rurais significativos dentro do espaço urbano de Cubatão. 


\section{Considerações Finais}

A industrialização ocorrida em Cubatão gerou a riqueza e a pobreza simultaneamente, conforme Damiani (1984) descreveu. A situação de miséria vivida pela grande maioria de seus habitantes é constituída por momentos da impossibilidade e das dificuldades da reprodução social, mas também por momentos que propõe a invenção, a ousadia, a transgressão.

Nesse trabalho identificamos elementos significativos de campesinidade. As situações que encontramos em Cubatão remetem às práticas e valores de uma ordem moral camponesa. No entanto, verificamos que essas práticas não se espacializam sem conflito, dado que elas se dão em um contexto urbano, que é caracterizado como unidade de contradições, local de reunião dos conflitos, dos enfrentamentos, confrontações e sobretudo com fissuras por onde passa o desejo, que emerge das necessidades.

As práticas rurais que analisamos exprimem a forma de viver e de ser das pessoas que as praticam, imprimindo no espaço características específicas, evidenciando a apropriação através da lógica do uso, com base no costume. O cotidiano então passa a ser composto por elementos diversos, influenciando na reprodução do espaço dessa cidade - tão marcado por uma urbanização crítica, com características de segregação e fragmentação do espaço. O urbano que segrega, que tende à homogeneização, também reúne, restaurando a complexidade. Por isso que, diante da proibição da criação de animais, muitos encontram outras formas de insurgência, como a clandestinidade dessas atividades ou recriam outras, como as atividades envolvendo cavalos - essas não podem ser diretamente contestadas pelo poder público ou pela Vigilância Sanitária. Contudo, não deixam de ser um problema para o poder público, dado o modo como são exercidas: através da lógica do uso, e da expressão da campesinidade de quem as exerce. Existe uma sociabilidade envolvida na criação do cavalo na cidade. As brincadeiras (assim chamadas por nossos entrevistados) buscam a recuperação do lúdico, em contraposição à cidade que é ocupada pelo trabalho produtivo. Nesses momentos do lúdico, escapa-se do cotidiano de forma efêmera, como explica Lefebvre (2001). Da mesma forma, a horta também aparece como local de diversão, de "divertimento", de terapia, onde a 
reciprocidade se coloca como valor. Trata-se de uma real apropriação, relativizando, em muitos casos, o poder da mediação exercida pela propriedade privada. A vivência do rural (com todo seu simbolismo) se coloca então, dentro do urbano. $O$ desejo de ser da cidade e de estar no campo é uma constante para grande parte dos moradores de Cubatão. Sobretudo tendo vivenciado um processo de proletarização de caráter contraditório: inseridos na lógica do capital, que exige a mobilidade da força de trabalho, mas também se apoiando em redes sociais complexas que garantem uma inserção e espacialização no universo urbano de forma diferenciada. De certa maneira, tal processo não anulou completamente as possibilidades de recriação de práticas e valores referentes ao universo camponês, pelo contrário, em certas situações, contribuiu para acirrar antigas concepções, agora resgatadas e resignificadas. Porém, alguns outros fatores também favoreceram tal reapropriação cultural, como por exemplo, a disponibilidade de terras representada por espaços ocupados em margens de vias de circulação (ferrovia, rodovia e ruas), praças públicas, terrenos de empresas, terrenos baldios e públicos, além da permissão e até incentivo de empresas (como é o caso das ferrovias). A espontaneidade dos moradores entrevistados se destaca, acompanhada pelo tempo disponível conferido pela situação de aposentadoria. Embora tivéssemos encontrado muitos que complementam a subsistência com produtos da horta ou com os próprios animais criados nestas ou em outros locais, a interpretação desses espaços ou atividades sempre é feita através da lógica do uso, com base no desejo. O desejo também de apropriação da cidade, de construção de um novo urbano e, no limite, da recriação da alegria, como nos propõe Martins (1998). As brechas que o próprio sistema deixa é onde se manifestam os resíduos, onde podemos encontrar as necessidades radicais, ou seja, as necessidades que não podem ser resolvidas sem promover mudanças na sociedade. Esse embate se dá no plano do vivido, caracterizando o urbano em Cubatão com elementos da campesinidade dos sujeitos que tratamos. A cidade de Cubatão apresenta contradições relativas a sua forma e conteúdo, onde a relação urbanidade-ruralidade aflora com grande intensidade. 


\section{Bibliografia}

BECKER, Olga M. S. Mobilidade espacial da população: conceitos, tipologia, contextos. In: CASTRO, Iná Elias de et al. Explorações Geográficas. Percursos no fim do século. Rio de Janeiro: Bertrand, 1998.

CANCLINI, Nestor G. Culturas Híbridas: estratégias para entrar e sair da modernidade. São Paulo: Edusp, 1997, 387 p.

CANDIDO, Antonio. Os Parceiros do Rio Bonito: estudo sobre o caipira paulista e a transformação dos seus meios de vida. São Paulo: Duas Cidades, 2001.

CARLOS, Ana F. A. A Mundialidade do Espaço. In: MARTINS, José de Sousa. Henri Lefebvre e o Retorno à Dialética. São Paulo: Hucitec, 1986, 151 p.

A (Re)produção do Espaço Urbano. São Paulo: Edusp, 1994, 271 p.

COMPANHIA ENERGÉTICA DE SÃO PAULO. A Empresa: Histórico. Disponível em <http://www.cesp.com.br/site_emae/empresa/historico.asp.> Acesso em 05 set. 2006.

COSTA, Cléria B. Eu e as fronteiras do outro. Revista Travessia, São Paulo, Publicação do CEM , ano VII, n.19, mai./ago. 1994.

COSTA, Maria C. S. Entre o rural e o urbano: construção de tempo e espaço entre trabalhadores rurais temporários. Revista Travessia, São Paulo, Publicação do CEM, ano VI, n.15, jan./abr. 1993.

COSTA, Rogério H. Gaúchos no Nordeste: modernidade, des-territorialização e identidade. 1995. Tese (Doutorado em Geografia) - Faculdade de Filosofia, Letras e Ciências Humanas, Universidade de São Paulo, São Paulo, 1995.

COUTO, Joaquim M. Entre estatais e transnacionais: o pólo industrial de Cubatão. 2003. Tese (Doutorado em Economia) - Instituto de Economia da UNICAMP, Campinas, 2003. 
CUBATÃO. Disponível em: <http://www.novomilenio.inf.br/cubatao/> Acesso em: 02. jun. 2006.

DAMIANI, Amélia L. A crise da cidade: os termos da urbanização. In: DAMIANI, A. L.; CARLOS, A. F.; SEABRA, O. C. de L. (Org.). O espaço no fim de século: a nova raridade. São Paulo: Contexto, 1999 a.

. A metrópole e a indústria: reflexões sobre uma urbanização crítica. Revista Terra Livre: "Geografia, movimentos sociais e teoria", São Paulo, Ano XVII, n.15, p.21-37, 2002.

- As contradições do espaço: da lógica (formal) à (lógica) dialética, a propósito do espaço. In: DAMIANI, A. L.; CARLOS, A. F.; SEABRA, O. C. de L. (Org.). O espaço no fim de século: a nova raridade. São Paulo: Contexto, 1999 b.

Na busca das favelas o encontro do "peão" que permanece: as favelas de Cubatão num quadro de desenvolvimento do centro. 1984. Tese (Doutorado em Geografia) - Departamento de Geografia, Faculdade de Filosofia, Letras e Ciências Humanas, Universidade de São Paulo, São Paulo, 1984.

. Turismo e lazer em espaços urbanos. In: ENCONTRO NACIONAL DE TURISMO COM BASE LOCAL, 1, 1997, 2006, São Paulo. Resumos.

A geografia que desejamos. In: Boletim Paulista de Geografia/Seção São Paulo, São Paulo, AGB, n. 83, 2005.

DUMONT, Louis. Homo hierarchicus: o sistema das castas e suas implicações. São Paulo: EDUSP, 1992, p. 49-67 \& p. 369-375.

DURHAM, Eunice. A caminho da cidade. São Paulo: Perspectiva, 1978.

FERREIRA, César Cunha \& PASSERANI, Marildo (Org). Cubatão: a rainha das serra. São Paulo: Noovha América, 2005. Série conto, canto e encanto com a minha história...

GAUDEMAR, Jean P. Mobilidade do trabalho e acumulação do capital. Lisboa: Estampa, 1977.

GEERTZ, Clifford. A interpretação das culturas. Rio de Janeiro: LTC, 1984. 
GODÓI, Emília P. O trabalho da memória: cotidiano e história no sertão do Piauí. Campinas: Unicamp, 1999, p.11-108.

GOLDENSTEIN, Léa. A Baixada Santista: aspectos geográficos. São Paulo: Editora da USP, 1965, v. 4.

Estudo de um centro industrial satélite: Cubatão. 1970. Tese (Doutorado em Geografia) - Departamento de Geografia, Faculdade de Filosofia, Letras e Ciências Humanas, Universidade de São Paulo, São Paulo, 1970.

HOGAN, Daniel J. População, pobreza e poluição em Cubatão, São Paulo. In: MARTINE, George (Org.). População, meio ambiente e desenvolvimento: verdades e contradições. Campinas: Editora da UNICAMP, 1993.

INSTITUTO BRASILEIRO DE GEOGRAFIA E ESTATÍSTICA (IBGE). Disponível em: $<$ http://www.ibge.gov/cidadesat/default.php>. Acesso em: 29 jun. 2006.

JORNAL Costa Norte, Bertioga, p. 4 A, 01 e 02 de jun. 2006. ano XV, Ed. 759.

JORNAL Folha de Cubatão, Cubatão, p. 07, 26 mai a 01 jun. 2006.

JORNAL O Estado de São Paulo, São Paulo, Caderno G2-Agrícola, 19 jan. 2005.

LEFEBVRE, Henri. "Cotidianeidad y felicidad". In: Hacia el Cibernantropo (uma crítica de la tecnocracia). Barcelona: Gedisa, 1980.

Le retour de la dialectique: 12 mots clef pour le monde moderne. Paris: Messidor/Éditions Sociales, 1986.

A revolução urbana. Belo Horizonte: Editora UFMG, 1999.

. O direito à cidade. São Paulo: Centauro, 2001.

LEITE, José Sérgio. Identidade e cultura operária: aspectos da cultura da classe trabalhadora. Rio de Janeiro: UFRJ, 1982. 
LIMA, Rosirene M. O rural no urbano: uma análise do processo de produção do espaço de Imperatriz- MA. 2003. Dissertação (Mestrado em Geografia) Universidade Federal do Paraná, Curitiba, 2003.

MAGNANI, José G. C. \& TORRES, LILIAN. T (Org.). Na metrópole: textos de Antropologia Urbana. São Paulo: EDUSP, Fapesp, 2000.

. Sagrado: perene e atual. Prefácio. Revista Travessia, São Paulo, Publicação do CEM, ano XIV, n. 46, mai/ago. 2003.

MAIA, Doralice S. O campo na cidade: necessidade e desejo - um estudo sobre subespaços rurais em João Pessoa - PB. 1994. Dissertação (Mestrado em Geografia) - Universidade Federal de Santa Catarina, Florianópolis, 1994.

MARQUES, Marta I. M. De Sem-terra a "Posseiro", a luta pela terra e a construção do território camponês no espaço da reforma agrária: o caso dos assentados nas fazendas Retiro e Velha-GO. 2000. Tese (Doutorado em Geografia Humana) - Departamento de Geografia, Faculdade de Filosofia e Ciências Humanas, Universidade de São Paulo, São Paulo, 2000.

. Lugar do modo de vida tradicional na modernidade. SIMPÓSIO NACIONAL DE GEOGRAFIA AGRÁRIA E SIMPÓSIO INTERNACIONAL DE GEOGRAFIA AGRÁRIA: O campo no século XXI. 2., 1., São Paulo, USP, nov.2003. Texto apresentado.

O conceito de espaço rural em questão, $1^{\text {a }}$. versão. Revista Terra Livre: Geografia, movimentos sociais e teoria. São Paulo, Ano XVIII, n.19, p.95-112, jul./dez. 2002.

A relação campo-cidade: em questão a subordinação do campo pela cidade, $1^{\text {a }}$. versão. CONGRESSO BRASILEIRO DE GEÓGRAFOS (Setenta anos da AGB: as transformações do espaço e a geografia no século XXI), 6, Goiânia, 18 a 23 jul.2004. Texto apresentado.

MARTINS, José de S. (Org.). Henri Lefebvre e o retorno à dialética. São Paulo: Hucitec, 1986, $151 \mathrm{p}$. 
A aparição do demônio na fábrica, no meio da produção. Revista Tempo Social, São Paulo, Ver. Sociol. USP, n.5 (1-2), p.1-29, $1993 a$.

A chegada do estranho. São Paulo: Hucitec, 1993b.

A sociabilidade do homem simples: cotidiano e história na modernidade anômala. São Paulo: Hucitec, 2000, 210 p.

. A sociedade vista do abismo: novos estudos sobre exclusão, pobreza e classes sociais. Petrópolis: Vozes, 2002.

. Cultura e educação na roça, encontros e desencontros. Revista USP, São Paulo, n. 64, p. 28-49, dez./fev. 2004.

Fronteira: a degradação do Outro nos confins do humano. São Paulo: Hucitec, p.146-201, 1997.

. O problema das migrações no limiar do terceiro milênio. In: $\mathbf{O}$ fenômeno migratório no limiar do terceiro milênio: desafios pastorais/apresentação Luiz Bassegio. Petrópolis: Rio de Janeiro, Vozes, 1998.

Os camponeses e a política no Brasil. São Paulo: Vozes, 1995.

MEGALE, Januário Francisco. A bananicultura no litoral paulista, um estudo de geografia econômica. 1975. Dissertação (Mestrado) - Faculdade de Filosofia, Letras e Ciências Humanas, Universidade de São Paulo, São Paulo, 1975.

MELLO, Sylvia L. de. Constância e permanência - as mulheres de um bairro da periferia de São Paulo. Revista Travessia, São Paulo, Publicação do CEM, ano III, n.7, mai./ago.1990.

$\begin{array}{llll}\text { MRS } & \text { LOGÍSTICA } & \text { S.A. } & \text { Disponível }\end{array}$ $<$ http://www.mrs.com.br/interna.php?nomPagina=mapa_do_site.php\&ldSecao=0> Acesso em: 05 set. 2006.

OLIVEIRA, Ariovaldo U. Agricultura brasileira: transformações recentes. In: Geografia do Brasil. São Paulo: Edusp, 1996. Modo capitalista de produção e agricultura. São Paulo: Ática, 1986. 
PENNA, Maura. Caçando um lugar: A identidade regional no trajeto da exclusão. Revista Travessia, São Paulo, Publicação do CEM , ano VII, n.19, 1994.

PERALTA, Inês G. O caminho do mar como fator de localização progresso e decadência de Cubatão: subsídios para a História de São Paulo. 1971. Dissertação (Mestrado em História) - Faculdade de Filosofia, Letras e Ciências Humanas, Universidade de São Paulo. São Paulo, 1971.

O impacto da industrialização sobre o desenvolvimento urbano de Cubatão. 1979. 307 f. Tese (Doutorado em Geografia) - Faculdade de Filosofia, Letras e Ciências Humanas, Universidade de São Paulo, São Paulo, 1979.

PEREIRA, Marly. T. Agricultura urbana e periurbana. Qualidade de Vida. São Paulo: Universidade de São Paulo, n.11, abr. 2000.

PINTO, Celma de Souza. Cubatão, história de uma cidade industrial. Cubatão: Ed. do Autor, 2005, 194 p.

PÓVOA-NETO, Helion. Migrações internas e mobilidade do trabalho no Brasil atual. Novos desafios para a análise. Experimental, São Paulo, n.2, p. 11-24, 1997. Versão modificada de: Migration and labour mobility in contemporary Brazil. New challenges for analysis. The european geographer, Lisboa, v. 9, p.44-52, 1995.

PREFEITURA MUNICIPAL DE CUBATÃO (PMC). Plano Diretor do Município. Cubatão, 1998.

. Disponível em:

$<$ http://www.cubatao.sp.gov.br/noticia.asp?codigo=248\&COD_MENU=84\#> Acesso em: 02 jun. 2006.

QUEIROZ, Maria I. P. de. História de vida e depoimentos pessoais. Sociologia, São Paulo, v. 15, n.1, 1953.

RAMOS, Aluísio W. Espaço-tempo na cidade de São Paulo: historicidade e espacialidade do "Bairro" da Água Branca. Revista do Departamento de Geografia, São Paulo, n.15, p. 65-75, 2002. 
ROESE, Alexandre Dinnys. Agricultura Urbana. Disponível em: $<\mathrm{http}: / / w w w$.agronline.com.br/artigos/artigo.php?id=112\&pg=3\&n=3>. Acesso em: 07 mai. 2006.

SALIM, Celso A. "Migração: o fato e a controvérsia teórica", In: ENCONTRO NACIONAL DE ESTUDOS POPULACIONAIS, 8, 1992, Campinas. Anais. Campinas, ABEP , v. 3, 1992.

SARTI, Cynthia A . São os migrantes tradicionais? Revista Travessia, São Paulo, Publicação do CEM, ano VIII, n. 23, set./dez. 1995.

SEABRA, Odette C. A insurreição do uso. In: MARTINS, José de S. (Org.) Henri Lefebvre e o retorno à dialética. São Paulo: Hucitec, 1986, 151 p.

Urbanização e Fragmentação. Cotidiano e vida de bairro na metamorfose da cidade em metrópole, a partir das transformações do Bairro do Limão. 2003. Tese (Livre-Docência) - Departamento de Geografia, Faculdade de Filosofia, Letras e Ciências Humanas, Universidade de São Paulo, São Paulo, 2003.

. Territórios do uso: Cotidiano e Modo de vida. Cidades, v.1, n. 2, p. 181-206, 2004

SILVA, José A. B. da. A rodovia dos imigrantes e a questão da moradia em Diadema. 2003. Trabalho de Graduação Individual - Departamento de Geografia, Faculdade de Filosofia Letras e Ciências Humanas, Universidade de São Paulo, São Paulo, 2003.

SIMMEL, Georg. A metrópole e a vida mental. In: VELHO, O.G. et al. O fenômeno urbano. Rio de Janeiro: Zahar, 1963.

TULIK, Olga. Parâmetros geográficos: a organização do espaço da Baixada Santista antes do surto cafeeiro em São Paulo. 1987. Tese (Doutorado) Departamento de Geografia, Faculdade de Filosofia Letras e Ciências Humanas, Universidade de São Paulo, São Paulo, 1987.

VALE, Ana Rute do. Definindo o conceito e descobrindo a plurifuncionalidade do espaço periurbano. In: CONGRESSO BRASILEIRO DE GEÓGRAFOS, 5, Goiânia, 2004. Anais. Goiânia, AGB, 2004, 8 p. 
VALETTE, Elodie. A economia rural periurbana ou inovação em periferia: o caso de Montpellier (França). Interações. Revista Internacional de Desenvolvimento local. Campo Grande-MS, v. 5, n. 8, p. 9-19, mar. 2004.

WANDERLEY, Maria de N. B. Olhares sobre o "rural" brasileiro. Recife, out.1999. Disponível em: <http://www.locus.org.br/files/OLHARES.pdf> Acesso em: 28 abr. 2006.

WOORTMANN, Klass. (1990). Com parente não se neguceia: o campesinato como ordem moral. In: Anuário Antropológico, Brasília/ Rio de Janeiro: Edunb/Tempo Brasileiro, 1990, p. 11-73. 


\section{Anexos}




\section{Anexo A - Reportagens sobre Festas em Cubatão}

\section{Shows marcam a volta de Cubatão como a capital do rodeio na Baixada Santista}

Teodoro \& Sampaio vão se apresentar no encerramento do evento

O mundo mágico dos rodeios estará de volta à Cidade no período de 19 a 29 deste mês, com a realização do evento "Cubatão: duas semanas de pura emoção", que tem programado ainda nove grandes shows de artistas já consagrados. Segundo o organizador e locutor oficial Serginho Viola, será montada arquibancada com 15 mil lugares no Kartódromo Municipal, além da praça de alimentação e barracas para venda de souvenires.

A abertura oficial será no dia 19, quinta-feira, às 20 horas, com o show da dupla Serginho Viola \& Barra Mansa. O ingresso para este show será um quilo de alimento não-perecível.

Na sexta-feira, dia 20, a banda West Rock, com o melhor da música country. O público jovem será atendido com o novo show dos irmãos do KLB, que se apresentarão no sábado, dia 21. No domingo, dia 22, a dupla Rio Negro \& Solimões, apresentando seus grandes sucessos.

Na quarta-feira, dia 25, será a vez dos pagodeiros do Bokaloka desfilarem seus sucessos. No dia 26 , quinta-feira, o Arriba Saia; dia 27, o funk romântico do Samba Crew; Netinho de Paula será a atração do sábado, dia 28; e encerrando a programação os reis do vaneirão, Teodoro \& Sampaio.

Serginho Viola destaca que estão programadas montarias antes de cada show e também o já tradicional Bailão Caipilona, que será realizado ao final das programações em uma grande barraca de Iona armada no Kartódromo Municipal. O evento está sendo promovido em parceria entre a Prefeitura Municipal, por intermédio da Secretaria de Cultura e Turismo e da empresa Espora Batida, de Serginho Viola.

\section{Título do arquivo Secretaria de Cultura e Turismo/Imprensa}

Repórter José Terras MTb 13.553 Data 02/05/2005

http://www.cubatao.sp.gov.br/noticia.asp?codigo=1212\&COD_MENU=90

Acesso em 10/05/06 


\section{Cubatão faz a "Festa de São Lázaro" no domingo}

Programação começa às 12 horas e terá shows musicais, procissão e missa campal

A Festa de São Lázaro, retomada há cinco anos pela comunidade cubatense, volta a ter a efetiva participação da Igreja Católica. A programação começa às 12 horas, no Parque Municipal Anilinas (entrada pela Avenida Nove de Abril, no Centro), com a apresentação de diversos shows musicais, barracas de artesanato e de culinária com pratos doces e salgados, além de deliciosas guloseimas. Às 16 horas, começa a homenagem litúrgica com os fiéis saindo em procissão da Igreja Matriz Nossa Senhora da Lapa até a Capela de São Lázaro, no Parque Anilinas. No local, a comunidade católica e demais convidados participam da missão campal celebrada pelo padre Valdecir João dos Santos. Para os devotos do santo, a participação do pároco da Igreja Matriz é de grande significado, pois desde 2001 a liturgia vinha sendo feita por diáconos. Segundo os organizadores, a presença do padre Valdecir representa a reaproximação da igreja e o resgate de uma das tradições da festa.

Lenda - De acordo com relatos históricos, desde o século XIX, existe uma lenda que explica a ligação do personagem bíblico (que era leproso) com a cidade de Cubatão. O relato fala sobre um casal de leprosos que descia a Serra em busca de comida. Por um período, os moradores passaram a ajudar o casal com alimentos. Até que certo dia, só o homem passou a ser visto. Após um tempo, também debilitado, o homem acabou desaparecendo.

Curiosos, os moradores foram em busca do casal. Próximo ao pé da Serra, mais exatamente onde hoje está a Refinaria Presidente Bernardes, foi encontrado homem morto sobre o túmulo da companheira. Logo, providenciaram a construção de uma sepultura para o leproso, próximo ao de sua mulher.

Um antigo morador, Francisco Miguel Couto, comovido com aquela situação, construiu a Capela Santa Cruz dos Lázaros. A partir daí, há relatos de que milagres aconteciam em volta do local. As velas que eram oferecidas permaneciam acesas, mesmo estando sob fortes ventos.

Após a construção da capela sobre o túmulo do casal, uma festa em homenagem a São Lázaro passou a acontecer na cidade nos meses de maio. A festa aconteceu até o início da década de 50, quando a capela foi demolida para dar lugar a Refinaria. Para resgatar a tradição, a Prefeitura construiu uma réplica do santuário no Parque Anilinas. O evento voltou a acontecer em 2001, por iniciativa da presidente do Conselho Municipal de Cultura, Maria Albertina da Silva Mesquita e pelo historiador Ayres de Araújo Coutinho, desde então o administrador da Capela de São Lázaro.

Gerência de Comunicação Social

Repórter- Francisco Carlos dos Santos $\quad$ MTB20.900 25/05/2005

Festa de São Lázaro acontece neste domingo em Cubatão (Zanza 2 )

http://www.cubatao.sp.gov.br/noticia.asp?codigo $=1304 \& C O D \_M E N U=90$

Acesso em 10/05/06 


\section{Festa da Carne Seca recebe 25 mil pessoas}

\section{O evento é uma homenagem aos nordestinos que moram na cidade}

A quinta edição da Festa da Carne Seca, em comemoração ao $20^{\circ}$ aniversário do bairro Jardim Nova República, reuniu no último domingo, 24, cerca de 25 mil pessoas, na Alameda Deputado Esmeraldo Tarquínio Silva. Segundo o superintendente da Companhia Municipal de Trânsito (CMT), Edson Joaquim de Freitas, o evento nunca reuniu tantas pessoas como nesta edição.

Durante o evento, promovido pela Prefeitura de Cubatão, o público pôde consumir pratos típicos do nordeste preparados com carne seca, das 11 horas às 23 horas. Segundo o presidente da Câmara dos Vereadores e organizador da festa, Geraldo Guedes, a festa é um agradecimento ao povo nordestino que veio para Cubatão para participar do desenvolvimento industrial do país.

Foram distribuídos mil quilos de carne seca para 20 barracas, exploradas por entidades assistenciais ou comerciantes da cidade. Cada barraca recebeu cerca de $45 \mathrm{~kg}$ do produto para preparem pratos como carne seca na manteiga, acebolada, com abóbora, feijão tropeiro, mandioca, batata doce e farofa. Maria Aparecida Dias, que trabalhou na barraca da Igreja Vida Nova, conta que o evento é válido, já que a instituição conseguiu arrecadar fundos para ajudar o departamento infantil. "Valeu a pena esperar na fila para conseguir participar do evento", disse Maria Aparecida, referindo-se à disputa que há entre entidades para conseguir espaço na festa.

O Presidente da Conferência São José, José Pereira de Abreu, trabalhou como voluntário na barraca Sociedade São Vicente de Paulo, e explica que o dinheiro arrecadado na festa será destinado para a compra de alimentos para famílias carentes. "A comida na festa é de graça, mas as pessoas estão consumindo bastante bebidas. Estou satisfeito com a arrecadação que estamos fazendo".

Festa pacífica - O presidente da Câmara lembra que em cinco edições da Festa da Carne Seca, nunca houve uma briga no evento. "As pessoas estão aqui apenas para comer e se divertir", ressaltou.

Raízes - O nome da festa se justifica pelo bairro ter sido formado em maioria por nordestinos, que migraram para Cubatão na década de 50 , em busca de oportunidades, e ajudaram a instalar as principais indústrias da cidade. Atualmente, $60 \%$ da população cubatense é composta por migrantes nordestinos.

José Teixeira, que veio do Alagoas há 30 anos, conta que a Festa da Carne Seca é importante para que os nordestinos não esqueçam suas raízes. "Além disso, nunca presenciei uma confusão, a festa é ótima". O cearense José Roberto veio para a cidade há 40 anos e mora há 16 no Jardim Nova República. "Não existe nada melhor para matar a saudade da 'terrinha', mas eu não troco Cubatão por nada". Outro cearense, José de Lima, mora em Cubatão há 26 anos e revela que prestigia o evento há três anos, do início ao fim.

Um pouco antes do público cantar parabéns ao bairro, as autoridades presentes entregaram troféus e dinheiro para as barracas que apresentaram os melhores pratos e decorações. O bolo foi cortado às 19 horas, reunindo à mesa moradores, o prefeito Clermont Silveira Castor, o vice-prefeito Raimundo Valter Pinheiro Lima, o presidente da Câmara, Geraldo Guedes, os vereadores Donizete Tavares, Osvaldo Jordão e José Roberto Azzoline Soares, o "Alemão", além de secretários municipais.

http://www.cubatao.sp.gov.br/noticia.asp?codigo=1172\&COD_MENU=90 Acesso em 10/05/06 


\section{Vila Nova comemora 53 anos com a quarta edicão da Festa da Banana}

Os 53 anos de aniversário da Vila Nova serão comemorados no dia 20 de março com a quarta edição da Festa da Banana. As atividades começam às 10 horas e se estendem por todo o dia até o encerramento com a apresentação do grupo baiano Gerasamba. As 53 velinhas serão sopradas em um bolo de 15 metros.

O evento vai contar com 35 barracas que irão oferecer pratos feitos com a fruta, como tortas, doces e bolos. Cada administrador das barracas, a cargo de entidades, sociedades de melhoramentos, igrejas, creches, escolas e clubes, recebeu da prefeitura cinco caixas de bananas para preparar os pratos. A arrecadação das vendas será investida nos projetos sociais das próprias entidades.

No palco que será montado na Avenida Nações Unidas, esquina com a Rua Rio de Janeiro, as apresentações começam às 10 da manhã com a Banda Marcial Municipal de Cubatão. Em seguida, às $12 \mathrm{~h} 30$, entra no palco a banda de rock Subkhaos e, às 13h15, a MPB da Banda MP13. Às 14 horas começam os shows religiosos com a banda Jesus Música Viva, a dupla Toninho e Jonas e o gospel de Mara Lima e Elias Silva.

Às $17 \mathrm{~h} 30$ a música popular volta ao palco com o pagode do Grupo Maroto, a bateria da Escola de Samba Nações Unidas e os Irmãos Ribeiro. Às $19 \mathrm{~h} 45$ haverá o corte a a distribuição do bolo de aniversário.

Após o parabéns, os shows continuam com os grupos Futuro do Samba, Raiz da Serra, Banda Prevê da Bahia e o Gerasamba.

http://www.cubatao.sp.gov.br/noticia.asp?codigo=1027\&COD_MENU=90

Acesso em 10/05/06

\section{Festa do Peixe é neste domingo, em comemoracão ao aniversário da llha Caraquatá}

A Prefeitura de Cubatão, em parceria com a Sociedade de Melhoramentos União da llha Caraguatá, promove a Festa do Peixe, em comemoração ao $38^{\circ}$ aniversário do bairro. O evento será realizado neste domingo (16), a partir das 11 horas, na Avenida Nadir Tereza Esteves.

Serão distribuídos 800 quilos de peixe para 20 barracas, exploradas por entidades assistenciais ou comerciantes, preparar pratos a base do alimento.

Durante a programação, o público pode prestigiar a apresentação dos grupos "Vem K", "Oba, Oba", "Sem Limite", "Futuro do Samba”, “Jotinha Show”, "Meninos do Agreste” e "Quanta Loucura”.

http://www.cubatao.sp.gov.br/noticia.asp?codigo=1581\&COD_MENU=90

Acesso em 10/05/06 


\section{Vila dos Pescadores recupera tradição da Festa de São Pedro}

\section{Procissão pelo Rio Casqueiro levou pescadores do bairro até a raia olímpica}

Os moradores da Vila dos Pescadores retomaram no último domingo (03) uma de suas mais importantes tradições, a Festa de São Pedro, que contou com uma procissão pelo Rio Casqueiro do bairro até a raia olímpica no Jardim Casqueiro. A procissão contou com a participação de dez embarcações com cerca de 50 moradores do bairro, principalmente pescadores.

Além da procissão, a Festa de São Pedro contou com uma missa na igreja do bairro, que também ficou lotada para a lembrança do santo. A festa foi organizada pela Capatazia José Bonifácio, formada por pescadores da região, e contou com o apoio da Secretaria Municipal de Esportes.

A organização prestou homenagens a Senhorinho Enédio, morador do bairro que iniciou a tradição da festa, e a Manuel Ubirajara Pinheiro Machado. O evento contou com a participação do vice-prefeito de Cubatão Raimundo Valter Pinheiro, da deputada federal Mariângela Duarte e de representantes da Capitânia dos Portos e do Corpo de Bombeiros.

http://www.cubatao.sp.gov.br/noticia.asp?codigo=1435\&COD_MENU=90

Acesso em 10/05/06

\section{Festa do Caranquejo e do Camarão agita a Vila Natal}

\section{Será no dia 4, com Papai Noel e espetáculos musicais}

Em comemoração ao $25^{\circ}$ aniversário da Vila Natal, ocorre no próximo domingo (4/12) a $3^{\text {a }}$ Festa do Camarão e Caranguejo, das 10 às 24 horas, na Av. 25 de Dezembro, na Vila Natal. Com a presença de Papai Noel (que chega às 15 horas) e de diversos grupos musicais (a partir das 16 horas), a festa promete ser muito animada, com a montagem de 20 barracas de alimentação, que além do caranguejo e do camarão, também vão servir churrasco, frango e peixe. E, às 17 horas, haverá o corte do bolo gigante $(6 \times 1 \mathrm{~m})$, preparado pelo Departamento de Abastecimento e Nutrição da Prefeitura.

Segundo o presidente da Sociedade de Melhoramentos da Vila Natal, Jaime Silva Cerqueira, estão previstas barracas de entidades sociais, escolas, comerciantes e pessoas físicas, não só do bairro como também do Mário Covas, Caminho 2, Costa Muniz, Vila Esperança, Morro do Índio, Ilhabela e Sítio Novo.

A parte inicial da festa é para as crianças, com brincadeiras, pirulitos e palhaços. A partir das 16 horas, começam a se apresentar os grupos Art Musical, Os Cobras do Forró, Justino e Marizete, Grupo Ôba Ôba, Daiane \& Tatiane, e Andreza, a Princesinha do Forró.

A promoção é da Prefeitura de Cubatão, por meio da Administração Regional da Vila Natal e Vila Esperança, e neste ano a expectativa é de reunir cerca de 20 mil pessoas.

http://www.cubatao.sp.gov.br/noticia.asp?codigo=1725\&COD_MENU=90

Acesso em 10/05/06 


\section{$1^{\text {a }}$ Festa do Mocotó acontece neste sábado, em Cubatão}

Resgatar um pouco das raizes nordestinas e reavivar as lembranças da terra natal. Este é o objetivo da $1^{\text {a }}$ Festa do Mocotó que acontece neste sábado (19/06), na Praça Frei Damião, na Vila Nova, em Cubatão.

A promoção da Festa é da Associação dos Nordestinos da Região Mertropolitana da Baixada Santista que, para preparar os diversos pratos derivados do mocotó, colocará dez barracas a disposição do público.

A festa tem início às 10 horas, na Praça Frei Damião, situada nas esquinas das Avenidas Nossa Senhora da Lapa e Martins Fontes. No local, além dos pratos feitos com o mocotó o público em geral vai poder apreciar o caldo de feijão e caruru.

http://www.cubatao.sp.gov.br/noticia.asp?codigo=566\&COD_MENU=90 Acesso em 10/05/06

\section{Festa do Frango será no próximo domingo, na Vila São José}

\section{Avenida Tancredo Neves será interditada durante os festejos}

Preparados com carne de frango, pratos diversos, inclusive típicos de regiões do Brasil, fazem parte do cardápio das 20 barracas que estarão dispostas na Avenida Tancredo Neves, nas proximidades da Unidade Básica de Saúde (UBS) da Vila São José, durante a terceira Festa do Frango, que marcará a passagem do 44ํㅡㄹ aniversário desse bairro. A avenida terá o trânsito bloqueado durante as comemorações, que deverão incluir apresentações musicais e ações de cidadania. O evento será realizado no próximo domingo (4/6), das 8 às 22 horas. A promoção é da Prefeitura, por meio da Administração Regional da Vila Nova e da Secretaria de Cultura e Turismo, em parceria com a Sociedade de Melhoramentos da Vila São José.

A informação é do presidente desta Sociedade de Melhoramentos, Ednei Manoel de Souza, um dos organizadores da comemoração. Já de acordo com o secretário de Cultura e Turismo, Carlos de Freitas, a animação musical deverá ficar por conta de cerca de 20 grupos de ritmos diversos, a maioria deles da Cidade.

Espetáculos - A banda de forró paulista Arreio de Prata será a responsável pelo encerramento da programação dos espetáculos da Festa do Frango. A programação, que tem nada menos do que $90 \%$ de artistas cubatenses, começará às $10 \mathrm{~h} 30$, com o músico Mário Leite. Também subirão no palco: Band Renato; Banda Reflux, Auto Reverese, Só de Brincadeira, Dunga, No Eripping, Stéreo Willys, Os Aventureiros do Forró, grupo de Dança da professora Juliana, Justino e Marizete, Banda Bubbles, Arrocho o Bicho, Vem K e Arreio de Prata.

A princípio a festa aconteceria no dia 21 de maio, mas por medida de segurança, atendendo a um pedido da Policia Militar motivado pelo clima de violência naquela ocasião, foi então marcada a nova data, 4 de junho, oportunidade em que deverá contar com a presença de mais de 15 mil pessoas. http://www.cubatao.sp.gov.br/noticia.asp?codigo=2312\&COD_MENU=90 Acesso: 02/06/06 


\section{Anexo B - Apreensão de Cavalos}

\section{Prefeitura pode terceirizar apreensão de cavalos}

\section{Clermont aceitou oferta da União dos Cavaleiros para desenvolver a atividade}

O prefeito Clermont Silveira Castor disse aprovar a terceirização da apreensão de cavalos abandonados em vias públicas da Cidade. A responsabilidade pelo serviço deve ficar a cargo da Associação União dos Cavaleiros de Cubatão, que ofereceu seus préstimos para desenvolver essa atividade, já que a Companhia Municipal de Trânsito (CMT), setor ao qual cabe atualmente a atribuição não dispõe de local apropriado para abrigar os animais.

A oferta tornou-se oportuna devido à freqüência com que cavalos são vistos em suas e avenidas de Cubatão e ocorreu durante visita da diretoria da Associação ao gabinete do prefeito na manhã desta quarta-feira. O principal motivo do encontro com Clermont foi o pedido de cessão uso de um terreno, defronte do Conjunto Residencial Costa Muniz, sentido Curtume/Caminho dos Pilões, na Vila Noel. A área de lazer seria destinada à realização de rodeios, vaquejadas e treinamento de cavalos.

$\mathrm{Na}$ oportunidade estiveram reunidos, os secretários de Meio Ambiente, Eduardo Silveira Bello; de Planejamento, Luiz Fernando Verdinassi; e de Ação Governamental, Carlos de Freitas. Da União dos Cavaleiros, compareceram o presidente, José Severino da Silva (o Miúdo); o vice-presidente, José Maria Medeiros; a primeira tesoureira, Adriana da Costa; o diretor de eventos, José Canuto Pinto; o membro do Conselho Fiscal, Severino José da Silva; o diretor de propaganda e divulgação, Lourival Canuto da Silva;

http://www.cubatao.sp.gov.br/noticia.asp?codigo=303\&COD_MENU=90

Acesso: 10/05/06 


\section{Anexo C - Entrevista com José Severino da Silva (Miúdo) em 06/2006}

V- Então estamos aqui com o José Severino da Silva, né? O Miúdo, e ele vai contar um pouco da história dele, né? Então, Miúdo, eu queria entender, assim, onde você nasceu, onde você cresceu e quando você veio para Cubatão, prá você lembrar, como você veio, que transporte você utilizou. Eu trabalho com migrantes, então eu preciso entender qual foi o seu trajeto até chegar aqui. Se você é daqui mesmo, né? Aí você vai me contando um pouco da sua vida, eu vou perguntando e você vai falando.

M- Eu me chamo José Severino da Silva, nasci em quinze de novembro de 1956, né? No estado de Pernambuco, numa cidade chamada Limoeiro, mas me criei em Salgadinho.

\section{V- Salgadinho?}

M- Salgadinho, que é justamente é o // é uma cidade perto de Limoeiro, mas eu nasci em Limoeiro e me criei em Salgadinho, porque lá a cidade é uma cidade pequena, mas tem uma fonte de água no meio do rio Capivari que corta a cidade.

\section{V- Que coisa mais linda!}

M- A cidade, quando rio enche, né? Que ele deságua, então a cidade, ela fica dividida no meio, fica uma rua do lado, uma rua do outro. Agora cresceu mais, que eu saí de lá em setenta e cinco.

V- Setenta e cinco. Aí setenta e cinco, retornando à setenta e cinco, o que que você pensou que fez você sair de lá?

M- É, justamente, né? Antes de eu vim diretamente, partir do Norte para cá, eu vivia muito no Sul, cortando cana, cambitando cana, enchendo vagão de trem, era máquina não era trem, era máquina. Então eu fui um garoto criado praticamente na Zona Rural, né? Do Estado de Pernambuco. Então, prechera, a usina Tiuna, a usina Aliança, a usina Capene... Todas as usinas do Sul praticamente eu trabalhei nelas carregando cana, cambitando, cortando cana, então de tudo eu já sabia um pouquinho na área rural. Tirando leite em vaca, dando capim para vaca, né? 
Apanhando com serra. E quando eu cheguei em 1975, veio um irmão meu em setenta e quatro para Cubatão, né? Que hoje é falecido, e se instalou na Vila Elizabete. Então aí depois, em setenta e cinco ele mandou // que eu fui criado praticamente com ele, ele era meu irmão mais velho e adonde ele estava eu estaria presente, junto com ele, acompanhando a trajetória dele. Então a trajetória dele era cortar cana, cambitar, empeleitar, limpar conta, limpar cana, né. Que chama as conta mas é limpando uma conta de onze por onze, uma braça, que é a medição do Norte, né? Justamente. Aí ele mandou me buscar, e aí ele foi na (?), comprou a passagem e vinhemo. Cheguei aqui em 1975 e me instalei na Vila Elizabete. Na Elizabete, no quarto dia que eu estava aqui já em Cubatão, arrumei o primeiro emprego e fui trabalhar na SERVER Engenharia como ajudante, né? Ajudante (risos) geral.

V- Qual o nome do lugar?

M- Era na Vila Elizabete.

V- Então, que você foi trabalhar?

M- Fui trabalhar na SERVER Engenharia, na área da Cosipa.

\section{V- SERVER?}

M- SERVER Engenharia, é. Minha primeira ficha na carteira foi na SERVER Engenharia. E eu era pequeno, né? Como eu sou pequeno, por isso que eu chamo Miúdo, ainda sou pequeno, aí o engenheiro encarregado "Mas (?) criança" chamava de criança "esse pequenininho!" Aí então eles falaram que eu era miúdo, eles perguntaram porque eu nasci, meu nome era miúdo, aí eu falei "Ah, porque eu nasci de sete meis, né? Eu era bem chochinho". (risos)

V- (risos) Mas nasceu mesmo ou tava brincando?

M- Não, de sete meis. Por isso que...

V- É mesmo?

M- Porque quando eu nasci, eu tô com cinqüenta anos, então você imagina eu tô cinqüenta anos eu não cresci nada. Ai falava "Por que é que tu chama miúdo?" Ah, porque eu nasci de sete meis, a minha mãe, a minha avó, né? Elas contava para mim, já eu garotinho crescendo, "Olha, você chama Miúdo porque você era bem, era 
bem pequenininho". Aí ficou Miúdo e é um nome na cidade hoje conhecido, é Miúdo, né? $\mathrm{E}$ é conhecido por todas as autoridades, toda a liderança comunitária. // E comecei a trabalhar. Aí comecei de ajudante geral. Aí de ajudante geral, em cinco, seis meses // eu tenho no currículo, né? Aí eu teria que estar acertando para você para eu passar as data correta, que aí eu tenho as data correta, a trajetória. Eu comecei de ajudante, de ajudante eu fui a ajudante de serralheiro, né? Comecei a trabalhar com disco serra de diamante para cortar tijolo refretário para encher o alto forno da Cosipa, mandaram um teste lá para várias pessoas que trabalhava na sede, que era muita gente, e quem cortasse o tijolo // porque naquela época em setenta e cinco, ai na setenta e seis, já chegando em setenta e seis, o disco custava milhões, né? Que é o disco de diamante que é para cortar refretário. Aí chamaram aqueles ajudante geral e fizeram uma fila e deram um teste. $O$ pedreiro tava lá embaixo, marcava o tijolo e aquele que cortasse o tijolo na medida que quando chegasse lá encaixasse certinho, sem defeito, estaria aprovado para ficar naquela máquina e a função dele era só cortar o tijolo. Então às vezes cortava dois tijolo por dia, três tijolo....

\section{V- Nossa!}

M- Né? Mas a responsabilidade daquele tijolo, ela valia por um mês de trabalho, por dois mês de trabalho, porque se o tijolo, além de ser caro, o disco era mais caro ainda, então...

V- Não podia danificar.

M- Não podia danificar nem o disco nem o tijolo, né? Porque o pedreiro, refretarista, ele marcava aquele tijolo lá embaixo, aquele tijolo lá em cima era cortado com o disco de diamante e ele levava aí, no mínimo, vinte a vinte e cinco minutos para você dar aquele corte naquele tijolo e chegar lá e encaixa perfeito, né? Porque a massa do refretário é só um tipo uma cola, depois, com a temperatura,ela desmancha a coisa e o tijolo cola um no outro próprio para não passar temperatura nenhuma.

V- E que tijolo é esse?

M- É o tijolo refretário. É um tijolo que ele tem ate sessenta quilo. Então imagina, você tem tijolo até de dez quilo a sessenta quilo. Também tem de cinco quilo, é o 
tijolo refretário que vai fazendo ali circo, porque todo os alto forno são revestido com tijolo especial, né? Para que justamente ele güente a temperatura do alto forno.

V- Tá, então você começou a fazer esses tijolos pro alto forno.

M- É, cortava os tijolo para o alto forno, né?

V- Para a SERVER Engenharia. A SERVER Engenharia nessa época, ela...

M- Ela trabalhava tomando de conta da construção do forno poço que tem na Cosipa que é...

V- Forno poço?

M- É, forno poço é o nome que tem lá...

V- Ah tá.

M- Porque o forno poço é da onde vem o produto, despeja lá dentro, aí depois sai só a borra, né? Aí ele já vai para o carro torpedo, do carro torpedo ele é despejado na forma, da forma ele vai para a ilaminação, e da ilaminação aí vai sair na chapa, vai sair no chapão. E adonde é feito praticamente a borra do ferro, vem naquele panelão, aquele panelão deixa ele o líquido, sai dali de dentro pegado por um guindasto, vai até o carro torpedo, o carro torpedo // E aí o processo é longo, né?

V- Eu sei.

M- Então é historia. E aí eu me aperfeiçoei nessa profissão. Aí quando terminou o forno poço...

V- Ajudante de serralheiro.

M- É, ajudante de serralheiro. É, aí terminou, justamente aí já me classificaram, né? Como ringue. Eu nunca tinha passado por profissão nenhuma, aí o que era o ringue? O ringue era justamente aquelas máquinas, os guindastes, que pegava aqui um favo de peça e aí levava para vinte metros de altura, trinta metros. Então você estava lá com uma operadora e eu é que ia guiar você lá no manual, que hoje já é mais digital, mas eu ia guiar você colocar a peça lá, que lá estava o ajudante pra desengatar o cabo de aço e a peça fica lá. Seria uma peça de ferro // Qualquer 
equipamento que fosse para uma altura tinha que ter o ringue. Aí eu fui, peguei mais uma profissão. Era ringueiro, né?

\section{V- Era ringueiro?}

M- (risos) Ringueiro.

V- (risos)

M- E aí a minha função era o quê? Era, nós estava enchendo a fabrica de oxigênio com lã de vrido.

\section{V- Com o quê?}

M- Lã de vrido.

V- Lã de vidro?

M- A fábrica de oxigênio, né? Então ela tem uma camada dentro do adonde fica o oxigênio, ela tem uma camada de lã de vidro em volta dela, que é para justamente para ela manter a temperatura, manter tudo armazenado. Então eu ia trabalhar, tinha era vinte e cinco metros de altura, então eu tinha que estar olhando para o guindastero, né? Que era o operador da máquina, então eu dava um sinal para ele: "Para direita; para esquerda; sobe; desce" né? E ele entendia o meu sinal. Essa é a profissão de ringueiro. Então aí esta foi mais uma profissão que eu aprendi. Aí na seqüência, aí eu fui trabalhar na Franco Engenharia. Na Franco Engenharia eu já fui lá, já fui trabalhar como pedreiro. Nessa minha trajetória, eu fui trabalhar como pedreiro. Comecei a trabalhar como pedreiro pela Franco Engenharia, aí a Franco me transmitiu para manobra, né? Fez uma transferência, viu que eu era eu acho inteligente ou não inteligente, eu não sei ainda. Aí me transferiu para manobra. $\mathrm{Na}$ manobra eu passei a cachimbar.

\section{V- Cachimbar?}

M- Cachimbar, é cachimbo, né? Se chama cachimbo. A gente fala assim "Olha, o que é o cachimbo?" O cachimbo é o feitor, né? Então é aquela pessoa que está comandando ali dez, quinze, vinte pessoa e me levaram para um obra na adutora do quilombo, né? Que vem água para Cosipa, para as caixa d’água, para resfriamento e água para beber. Então ela vem da adutora do quilombo. E a obra era no meio da 
mata. Então aí eu ia tomar conta do encanador, soldador, carpinteiro, eletricista, tinha o mestre, o contra-mestre, o encarregado, o engenheiro e eu era o último, eu era o cachimbo. (risos)

V- Sei (risos)

M- Só que lá ninguém atendia, né? O mestre chegava lá falava uma coisa, ninguém // ouvia por ouvir. Mas você é soldadora, uma suposição, então você vai carregar um tubo nas costas? Para encanar água? Um tubo de água lá era só encaixado, mas tinha parte que às vezes, um dia ou outro, ia precisar da soldadora, do maçariqueiro. Então tinha que ter cada um na sua função, mas quando pegava a obra, no começo da obra, então era cavar, o pedreiro tinha que cavar buraco, o armador tinha que ajudar a cavar buraco, o encanador tinha que fazer // Então era uma obra no meio da mata, era quinze quilômetro de obra no meio da mata. E me mandaram para lá, eu como cachimbo, né? Aí depois, você já imaginou? Porque a palavra cachimbo, (?) cachimbo só serve para levar fumo...

V- (risos)

M- ...é o português da obra, vamo falar bem claro. Mas o que é o cachimbo? O cachimbo só serve para levar fumo, que é o cachimbo do Norte. (?) Eles associa isso, né? Mas a gente não ligava que era tudo brincadeira na obra, e aí me deram os cinqüenta homem para mim tomar de conta. E nesses cinqüenta homens tinha de todas as função, de eletricista, a guindasteiro, a tudo. E falavam "Miúdo, o que você fazer está feito". Né? Porque aí eu chegava, eu sabia que o encanador, ele não ia soldar. Nem o soldador ia carregar o tubo, era vice-versa. Mas eu chegava, a gente se reunia bem cedo quando batia o cartão, eu chamava todo mundo para uma reunião e nesta reunião nós fazia o quê? "Ó, pessoal, vamos faze aqui um mutirão, todo mundo exercendo qualquer uma função e vamos fazer a obra andar.". Então, olha, amanhã o cidadão precisava // ele tem um problema para resolver com o médico, aí eu já liberava ele, ele ficava sastifeito, dizia: "Vai, vai resolver seu problema amanhã. Mas hoje nós temos esse problema para a gente fazer." Então, eu dominava ali todas as área, todo mundo fazia serviço que não era dele, né? Porque olha, você chama um arquiteto para carregar o concreto, ele só vai se tiver uma boa amizade, vai falar "Sou um arquiteto". Você chama o soldador "Sou soldador". Então eu tinha aquela habilidade e eles tratava eu como Miudinho, e nós 
trabalhamo um ano e seis meses colocando esta água para adutora do Cosipa, com todas essas pessoas em funções variada, mas sempre atendendo quem? $O$ cachimbo, né? Porque ia ver o encarregado não tinha habilidade. O encarregado dizia para o soldador "Olha, eu preciso que você vá carregar o tubo" "Olha, eu sou soldador". Mas quando eu chegava para o soldador e dizia, "Olha, nós precisamo carregar um tubo" ele dizia "Olha, para você eu vou, mas para o encarregado eu não vou, para o engenheiro eu não vou. A minha função é essa, agora para você, o que você precisa nós vamos."

V- Você tinha crédito, né?

M- Eu tinha crédito com várias função, né? Porque também eles tinha crédito comigo. Quando eles pedia "Ah, eu tenho um problema de saúde para resolver, eu tenho uma conta para ir pagar, eu preciso ir ver um parente que está doente" "Olha, vai, o seu dia está ganho, está apontado" Então eu tinha aquela harmonia com todas as função e aí eu me tornei o feitor da manobra e passei // e aí terminou a obra. Ai falaram "Poxa, como é que nós vamo aproveitar o Miúdo?"

V- (risos)

M- "Como é que nós vamo aproveitar o Miúdo". Aí me deram uma classificação de assistente técnico, né? Então você vê eu não conhecia quase nada, mas eu fui classificado como assistente técnico para que? Para rastrea a Cosipa por cima e por baixo. E eu trabalhava // eu conhecia de tudo um pouquinho, né? E tudo sempre estava tentando aprender, porque eu vim do Norte, não sabia // só tomava água num pedaço de cuia, eu tentava sempre aprender de tudo um pouquinho para ter alguma habilidade para o futuro. E aí eu vim para a Cosipa. Disseram: "Olha, a sua função é tomar conta aqui da rede de água ácido" A água ácido, ela passa por uma galeria que começa no começo da Cosipa e despeja, praticamente no cais, lá no // mas despeja tratada, ela vai passando por vários processo para quando chegar lá, todo o ácido que tinha na água já está fora, não tem nada. Só que, até ela chegar lá, o tratamento, ela passava as veiz dava um vazamento // quando havia vazamento d'água, ele ficava na galeria e dava infiltração que o ácido comia a parede. Vai para lá, vai para cá e vinha todo o tipo de material, técnico de um lado, técnico de outro, "Como é que nós vamos vetar a água"? "Como nós vamos tampar a água?" Porque quando comia a água ácido comia a parede, aí a infiltração do outro lado que estava 
abaixo da maré, né? A maré estaria acima da parede, começava a cair na galeria. $E$ vinha técnico de tudo quanto era lado. E aí eu arrumei uma (?) que fazia panela de barro, boi de barro para brincar, né? Aquela argila.

V- Sei (risos)

M- Aí eu falei "Olha, traga um caminhão de argila", para ver se o barro o ácido não comia.

\section{V-Ah é?}

M- O barro o ácido não comia. E eu descobri isso daí através de várias experiência que nós fazia, porque todo o material o ácido comia e o barro, a argila, né? Aquele massape de você fazer ligado, misturava ele no cimento e chega lá onde tivesse vazamento, colocava, primeiro nós fizemos uma experiência numa galeria. Onde passava o ácido puro e fizemos duas paredezinha. $\mathrm{E}$ o ácido comia, o tijolo cozinhado, mas não comia o barro. E fizemos a parede lá e durou mês e mês e mês e mês e ela continuou do mesmo jeitinho. Aí foi adonde a gente começou a fazer esses trancado. Porque vinha até técnico da Vedacite, né? Daquela // do material vinha, né? (?) por ser inteligente demais, e com o próprio barro a gente começou a tampar. Aí terminou o serviço eu falei "e agora?"

V- Água o quê você falou?

M- Água ácido, né? Água ácido é a água que vai // Primeiro o aço, quando sai a chapa ela cai numa piscina de ácido, né? De água ácido que faz // onde dá o choque, que é para ela se transformar, né? Sair do ferro, passar para o ácido, por isso que chama (?) que é o nome (?) a batida para ela aperfeiçoar e ficar a chapa depois que (?) laminação de aço, etc e etc. Aí o que é que aconteceu? Trabalhei mais um ano. Aí terminou, aí o engenheiro, né? Que terminou o contrato da empresa // Isso eu já estava, né? Setenta e sete, setenta e oito... Aí em setenta e nove me chamaram para trabalhar pela Franco lá na ponta da praia.

\section{V- Franco?}

M- É, Franco Engenharia. Aí eu comecei a trabalhar lá, e a gente trabalhando, foi para lá, veio pra cá, e era um engenheiro da Dersa na época que falou "Olha, eu preciso de um rapaz para trabalha com nós lá" E me levaram para lá e eu fiquei 
trabalhando na manutenção da estrada velha, né? Que fazia paralela à Imigrantes, então tem a Imigrante // hoje tem duas imigrante, mas na época só tinha uma. Então é uma estada que fazia todos os círculos, né?

\section{V-Ah é?}

M- É, tem uma estrada serviço que faz todo os círculos para chegar em cima da Imigrante. Aí eu fui trabalha. Aí me deram uma turma, então lá o mosquito dentro da mata era demais. Mas eu já tinha experiência, na do quilombo, aí na Imigrante era café pequeno. Só que era para reforma a estrada velha. E aí me deram pedreiro, me deram carpinteiro, me deram marteleteiro, né? Cada função eles trouxeram um. Só que as pessoas não se adaptava. Como que não se adaptava? O pedreiro estava lá, às vezes era para tapar um buraco do meio do barranco, né? Que é quando desbarrancava, então fazia um concreto, fazia chapiscar uma massa grossa// Ah, eu sou pedreiro eu vou trabalhar aqui mesmo. Então o que que eu fazia? Eu pegava os ajudantes que não sabia de nada, dava pra ele uma colhe, né? Uma desempenadeira, né? Porque era só para jogar massa e ia classificando ele lá, "Você vai sair daqui pedreiro!" E quando alguém tinha alguma caixinha para fazer, ele já ia fazendo, ele tirava a medida, ia lá, fazia // Então classificava o ajudante para justamente ele ter uma profissão. E ali naquele meio termo ele ia se desempenhando. Quando ele fosse trabalhar numa obra grande, ele já tinha, pelo menos, uma noção de como era chapisca uma parede, como era reboca, né?

\section{V- Tá.}

M- E aí eu me adaptei a isso. Como? Eles ia e vinha até de pé. Não esquentava a cabeça, porque lá na obra, era longe. Tinha dia de você andar quatro cinco quilômetro para chegar.

\section{V-É?}

M- Porque não tinha condução para traze. Trabalhei mais dois anos e pouco na parte da EcoVia

V- Já era EcoVia?

M- Depois nós fomos trabalhar // Já era // Não, era a Dersa. 


\section{V- Dersa.}

M- Que hoje é EcoVia, que ainda continua Dersa

V- E esse pessoal que não se adaptou que o você falou, eles saíam fora?

M- Saíam fora porque, veja bem, você às veiz está numa função, mas aquela função não é a sua profissão real. Você está ali para justamente, na sua profissão, mas não tem o serviço da sua profissão. Então você fala "Se amanhã eu fosse chamado" você ia. Então o que ia acontecendo? Fechava o pedreiro hoje, amanhã o pedreiro arrumava um serviço melhor, que era na profissão dele: "Eu vou embora". Então a gente fazia com que, fazia o paliativo com os ajudante. Porque os ajudantes ele já tinha interesse em aprender uma profissão e dali ele não ia sair um profissional de linha, mas ele já ia sair com uma noção e uma profissão na carteira, né? Porque...

\section{V- Era negócio para eles, né?}

M- Era negócio para eles. Então eles se interessava, né? Dizia, olha... Pegava aqui, olha, "Até dez hora ou até meio dia, a hora que voces terminar esse serviço, essa sala, o dia tá ganho". Então você tinha avanço do serviço porque o mosquito era demais, não deixava você trabalhar. Então tem aquilo, trabalhando por hora você se encosta, então tinha essa habilidade. Essa habilidade eu ganhei através da SERVER e fui passando por (?).

\section{V- Tá.}

M- E aí quando parei essa obra da a Imigrantes, aí me levaram para trabalha em mais uma obra na praia. Então era na praia, né? Comecemo de Praia Grande à Manganguá. E aí eu // Era até numa firma chamada de Irmão Prata e a gente, eu que ficava num alojamento na beira da praia, e na beira da praia // e qual era a função nossa? Era só fazer manutenção para os turista que vinha, né? Porque fimde-semana, né? Sábado, domingo, feriado, então descia muito turista. Então vou ver uma casa tinha um entupimento, outra casa tinha // e eu já tinha conhecimento em todas as áreas, montei uma equipe e trabalhei mais dois anos. Então parei de trabalhar fichado em obra quando saí do Norte em 1980 e em 1980 eu parei de trabalhar fichado e fui trabalhar em outra área.

\section{V- Em quê?}


M- Aí eu comecei a vender pão.

V-Ah é?

M- (risos) Aí eu fui para // né? Morava no Pica-Pau e comprei um fusca e velho falei "Ah, vou vender pão".

V- Decidiu assim?

M- Decidi assim. "Agora vou tentar viver a vida trabalhando para mim", né? Montei um negócio, o negócio que eu montei foi vender pão. Então fui vender pão na Vila Esperança, que é o bairro que eu moro hoje, aí comecei a vender pão. Só tinha seis casas, quando eu passei a vender era seis situante, né? Era o seu Francisco, o finado Valdemar, o finado Orlando, o Tigrão e ainda hoje ainda existe lá o Carlão, a Silvani, tem uma história, né? Desse pessoal que eu acompanho. // E fiquei lá, aí o primeiro bar do barro foi meu, eu já montei um bar que só tinha fogão, né? Dois bujão, me atoquei para justamente fazer. $\mathrm{E}$ uma geladeira. // $\mathrm{O}$ povo chegava ali parava no pão ou o povo do sítio vinha e (?) Só que o bairro foi crescendo, o bairro foi crescendo, o bairro foi crescendo. E quando eu fui o primeiro dia tinha seis casa, no quinto dia na Vila Esperança já tinha vinte e cinco casa.

V- No quinto dia?

M- No quinto dia já tinha vinte e cinco casa. Eu digo "Meu Deus do Céu", como o negócio é // Eu cheguei a vender dois mil e quinhentos pão por dia.

V- Dois mil e quinhentos pães?

M- Dois mil e quinhentos pão por dia. Porque eu era um padeiro, eu vendia pão, eu vendia café, né? Eu vendia de tudo. Quando acabava eu vinha no centro da cidade e levava para o povo. Aí depois foi se abrindo vários comércio. Mas o primeiro bar da Vila Esperança foi o meu, o primeiro padeiro foi eu aí eu dizia "E agora, o que eu vou fazer?"

V- Mas esse sucesso do pão estava com a vida ganha. Dois mil e quinhentos pães...

M- É mas deixava um centavo de lucro, eu vendia quantidade para ter lucros pequenos., entendeu? Porque o povo era carente e eu entregava, vendia nas portas, 
né? Eu saía já todo dia, todo mundo já sabia o horário que eu ia passar, dava umas buzinada com a buzina, o povo já ia comprar o pão, já ia busca.

V- Tá.

M- Então eu não vendia fiado, né? Vendia sempre a dinheiro, ganhava aí mixaria mas...

V- Era certo.

M- Era certo. Era melhor do que eu ganhar dez centavos, dois centavos, três centavos, quatro centavos. Então eu ganhava um centavo mas era // eu sabia que, no final da tarde, eu tinha justamente o que me manter. E comecei a ...

V- E era só na Vila mesmo?

M- Era só na Vila, ficava só na Vila, né? Aí depois começou a abrir um botequinho em cima do outro, falou "Olha, Miúdo vai enricar". Aí eu parti para a criação de porcos.

V-(risos)

M- Que quando o negócio pegava de um lado, aí eu peguei (?), né? Comprei um porca, né?

V- Comprou onde essa porca?

M- Lá do sítio do Carlão.

V- Onde é o sítio do Carlão?

M- É lá na pedreira.

V- Na pedreira?

M- É na pedreira que fica ali depois do Vale Verde, né? Aí eu fui, comprei uma porca, aí depois já apareceu o seu Francisco, falou "Ah eu vou te dar uma porca também de meia", né? Eu comprei uma bacurinhazinha e aí o seu Francisco já me deu uma porca de // ele ainda mora na Vila Esperança e o seu Francisco (?) da Nobrega. Ele me deu uma porca cheia de meia, então ela já estava, né? Esperando 
bacurinho e em três meses já teria uma ninhada. Então se desse doze, seis era dele, seis era meu e eu tinha de cuidar. E eu comecei a criar, né? A que eu comprei, a porquinha pequenininha, a leitoa e a porca já // a porca grande do seu Francisco que me deu de meia. E quando foi com três meses ela deu cria, deu doze bacurinho.

V- É?

M- Olha que eu já tenho seis bacurinho, né? Até hoje eu tenho // eu conto a história mas eu ainda tenho a foto dos porquinhos! (risos)

V- Ah, você tem a foto? Ai olha a gente podia digitalizar depois...

M- É porque a nossa história aqui eu estou te contando, mas a história se você estiver presente mesmo aonde eu moro e aí eu vou te passar tudo documentado, entendeu? // Aí o que aconteceu? Eu digo "Caramba!" e (?) eu cheguei a ter cento e vinte porcos, né? No quintal.

V- Cento e vinte porcos no quintal. Quando que foi isso mais ou menos?

M- Noventa e três, noventa e quatro, noventa e cinco, né? Porque eu já vinha de longa trajetória. E aí o que foi que aconteceu? Eu cheguei em noventa e dois, me passaram a sociedade do bairro para mim tomar conta. Aí já entrei em outro ramo, era dirigir a comunidade. Aí dirigi a comunidade. Então buscar a melhoria para a comunidade, né? Tentar ajudar, conhecer a população, dizer para ela // que eu já conhecia // mas dizer para ela a verdade, né? Dizer sempre // a verdade dói. Sempre dizer para ela "Olha, você está errada dona Maria, você está errado seu José, você está errado seu Francisco" porque eu era o sexto morador do bairro. Então eu conhecia o bairro// Que nem seu Francisco quando eu fui para lá, que nem o finado Orlando que já morreu, o finado Valdemar // Eu conhecia o bairro e como ele começou, né? E você vê que hoje nosso bairro tem cinco mil cento e setenta e duas casas.

V- E quando você foi morar lá? Que ano?

M- Em 1981.

V- Oitenta e um. Você saiu lá do morro do Pica-Pau... 
M- Eu saí do morro do Pica-Pau porque eu já morava lá e no Pica Pau já em oitenta e oitenta e um, já dizia assim: "Olha, o Pica Pau vai sair", que hoje é o conjunto Mario Covas.

V- Isso. Você já ficou sabendo que ia sair e já se adiantou.

M- Eu já acreditava que sairia, né? Poderia demorar vinte anos que nem demorou vinte e anos.

V- É, são coisas que as vezes demoram ou então não, né?

M- Né? Mas aí eu via que o acesso era ruim para de eu criar a minha família e eu estava // aí já tinha o primeiro filho, né? Já tinha o meu primeiro filho e eu saberia que a família ia crescer, que eu tinha uma noção que a família minha ia crescer. Eu digo "eu vou para Vila esperança". E cheguei na Vila esperança e me instalei no primeiro ponto, no primeiro bar...

V- E ali onde você mora, era terra?

M- Era.

V- Não era mangue?

M- Tem a faixa de manguezal e tem a faixa de bananal, né?

V- Isso é legal.

M- Porque tem a faixa de // todos ali é que antes passar a pista, ali era bananal. Mas onde passa a Pedro Taques, antes de passar a Imigrante, antes de passar a ferrovia, era um bananal.

V- Era bananal?

M- Era bananal

V- E quem plantava banana naquela época?

M- Ah, quem plantava banana era o seu Serafim, né? O finado Orlando, o finado Valdemar. Tem um sítio ainda, lá do lado da pista, tem o sítio dos Queiroz. Aqui era assim, então o sítio atravessava... 


\section{V- Ele descia?}

M- Descia até encostar no mangue, porque depois, né? Que tem a família Mesquita, tem ainda tem até um porto lá que é adonde eles transportava a banana pela via alta para trazer depois na linha.

V- Onde é esse porto?

M- É em frente ao Vale Verde. Que tem um rio, aí você desce, era o porto// do bananal já está lá só// era o porto que ficava lá

V- Tá. Então, esse bananal do sítio dos Queiroz ele descia, não tinha ainda a Imigrantes...

M- Todo ele, todo ele. É, não tinha a Imigrantes...

V- Nem tinha a linha de trem.

M- Nem tinha a linha do trem, nem tinha a Pedro Taques, certo?

V- Ah. E aí você se instalou lá.

M- É, quando eu fui para lá, aí já tinha, mas já tinha sido indenizado.

V- O pessoal da banana?

M- Depois da linha // Justamente, porque veja uma coisa, aqui está a Imigrante, aqui está a Pedro Taques e aqui está a linha, né? Então o que que acontece? // Mas isso aqui não tinha nada. Então, a parte depois da linha, ficou os bananal, ficou a parte de sítio, né? Adonde o povo via que era só mato, então era sítio.Vila Natal era, não tinha casa, era só// Quando eu fui para lá, Vila Natal não existia, né? Então toda Vila Esperança, ela tinha a linha férrea, uma estradinha beirando a linha férrea e os sítio, os situante que vivia lá.

V- E por que que será que a Vila Natal depois se desenvolveu e ficou urbanizada e..

M- Porque a Vila Natal foi feita através da Vila Esperança.

V- É mesmo?

M- A Vila Esperança, ela já é duas vezes construída e reconstruída 
V- Nossa, que interessante que você está falando!

M- É, porque a Vila Natal, quando o prefeito era o Passarelli, ela não existia. Aí começou uma invasão, né? Então aí pegou, praniou, aterrou e o que é que aconteceu? Fizeram a urbanização correta, né? Com casa, deram loteamento todinho para todo mundo...

\section{V- Com rua?}

M- Com rua e tudo e trouxeram o povo da Vila Esperança. Então Vila Esperança ficou naquela época quinze ou vinte casas. Eu não quis sair. A (?) da dona Cecília , né? O prefeito também na época "Vamos (?), vamos para lá" eu falei "Não, eu vou fica aqui mesmo." Só que eu ainda estava quase indo para o meio da Vila, eu não estava onde eu estou hoje, né?

\section{V-Ah é?}

M- Eu já tinha a minha casa lá onde era o ponto final, que era um pequeno sítio// Lá onde eu criava meus porcos, onde...

V- Ah, era um pequeno sítio?

M- Era um pequeno sítio com trinta e cinco por setenta.

V- Trinta e cinco por setenta.

M- Por setenta (?). Então lá é adonde eu estava e tinha um pontinho de comércio, que era o barzinho aonde eu comecei que tinha feito um barzinho, né? Que está até lá hoje, que hoje é uma adega, que foi que a Dona Ciça que é moradora, que é antiga, que está lá que me arrumou o terreno, né? Que ela já era uma das primeira, quase primeira moradoras mais junto com o Tigrão e o seu Francisco.

V- Tá.

M- Ela falou "Olha um presentinho para você", ela me deu o terreno, não me vendeu. E daí, mais do outro lado eu já tinha um Jeep, aí eu troquei no Jeep, foi aí que eu comecei a criar os porcos, né? E comecei. Aí, nessa criação, eu criava, matava e vendia. Vendia a carne, que já era uma tradição que no Norte, né? Tem. 
V- Ah é? Lá como é que? Porque assim, meus pais são de Minas, então do Norte mesmo eu não entendo muito.

M- É, mas em Minas é quase a mesma coisa do Norte. Tanto que lá tem a feira livre, você leva lá uma galinha, leva um bacurim, né? Leva um preá-da-Índia para vender nas feira, porque as feira lá sempre não são que nem aqui. As feiras é no meio da rua, é a vontade, né?

V- Tá.

M- Você chega lá com um caminhão de manga, despeja em cima de uma lona...

V- Qualquer um chega e vende o que quiser.

M- Vende, né? Vende para a comunidade situante. Do sítio vem para a rua e da rua eles fazem o negócio deles.

V- Tá.

M- Entendeu? Então as feiras de Minas, que nem no Norte, sempre é assim. Então tem carne de sol, né? E aí que que acontece? Quem é que não gosta de um sarapatel? O Nordestino.

V- Sei.

M- Não gosta de uma buchada? Em Minas quem é que não gosta de um queijo? Quem é que não gosta de uma polenta, né?

V- Claro.

M- Então é a comida forte, é a comida que se você tomar um café bem cedo, com umas comidas dessa, você leva o dia todinho. Então eu comecei vender a carne de porco.

V- Daí vendia lá..

M- Eu vendia na cidade, né?

V- Dos carrinhos de... Como?

M- Vinha, montava uma banca, montava uma banca... 


\section{V- Onde essa banca montava?}

M- Na rua São Paulo. Tem aqui na rua São Paulo, né? Que cortava a (?) na rua São Paulo, lá na (?) seu Manoel, na esquina. E mais na cidade daí tinha várias (?) porque já tinha também os primeiros que já vivia nessa tradição: o seu Francisco, o Severino, a (?) vivia nessa profissão também// o seu Francisco, o finado Orlando, todos esses já viviam com essa profissão. Então foi mais uma profissão que eu aprendi. A matar, né? Eu criava, matava e trazia para comercializar.

V- E eles também já criavam e..

M- E eles faziam isso já.

V- E onde que eles criavam?

M- Eles criava nos sítios lá, porque lá tudo era sítio.

V- Ah é, onde você falou....

M- Como eu falei, lá tudo era sítio.Aí conforme foi crescendo, aí eu cheguei a montar Associação dos Abatedores de Carne Suína, Bovina de Cubatão.

V-Ah é?

M- É, montei uma associação para a gente organizar, né?

V- Muito preocupada porque eu fico querendo // Que isso tem que estar gravado, né? Então assim...

M- Mas aí depois ...

V- Qualquer coisa você me repete! (risos)

M- Não, aí depois você vai marca um dia e você vai até lá // porque muitas coisas você pode levar até em documento.

V- Entendi.

M- Entendeu? Então muitas coisas você vai xerocar, né? Para montar uma história...

V- Olha que bênção, que Deus te abençoe. 
M- Você vai montar uma história pra que justamente // eu falei, mas você viu. Realmente o que eu falei está documentado.

V- Claro.

M- Porque se eu falar para você "Olha, eu fiz várias coisas", você vai falar "Poxa, mas o cara fez tudo isso?", né? Então, dando continuidade, aí comecei a criar a Associação dos Abatedores e a vigilância sanitária começou a pegar no pé. Só que os animal que havia, que eu criava, tanto eu criava que nem vinha da fazenda. Então eu tinha uma médica que acompanhava os meus animal, né? Uma médica veterinária.

\section{FIM DA FITA (Lado A)}

V- Vira ao contrário, né?

M- É.

V- Então, aí você falou que montou a Associação...

M- Montei a Associação, né? Para justamente ter uma qualidade, né? Inspecionada pela vigilância sanitária, para gente ter um mini abatedor na cidade.

V- Mini abatedor?

M- É, um mini abatedor, porque (?) a cidade, que queira ou que não queira era industrial. Mas quem está aqui é pernambucano, é baiano, é mineiro, é gaúcho, então ela é messiclada. Cubatense mesmo, praticamente são quase os filhos só. Tem poucos cubatense mesmo, nascido aqui. Mas quando eu falo nascido aqui o pai, mãe, avô, bisavô // e a história de Cubatão, ela foi no lombo do burro, no lombo dos animais, né? Nós temos aí a história, que era dois situantes que ficava no Largo do Sapo e a área do Largo do Sapo eles transportava as cargas no lombo dos burros, né? Eles vivia disso. E aí através disso, eu montei a Associação dos Abatedores de Carne Suína Bovina de Cubatão. Depois, na seqüência...

\section{V- E quem se associou?}

M- Todos aqueles que vivia com o comércio de criação de animal. Porque Cubatão nós não temo área rural. 


\section{V-Ah?}

M- Em Cubatão nós não temo área rural, né?

V- Não tem, né? Reconhecida, né?

M- Nem reconhecida.

V- Não é reconhecida, mas eu queria entender isso.

M- Porque quando fizeram a lei, né? As autoridade esqueceram que Cubatão teria que ter um espaço rural. Vamos supor, você caçava aqui uma área, deixava uma área rural para você criar uma cabra, criar uma vaca, né? Até se a prefeitura, hoje, quiser fazer uma mini fazenda, ela não pode fazer.

V- Não pode?

M- Não pode, porque não tem área rural. Se ela quisesse // eu vou querer construir uma granja, porque granja só para ter em área rural. E ela tem uma área rural que fica lá em cima da serra.

V- Na serra?

M- É.

V- Mas que lugar na serra?

M- Lá junto do São Bernardo, quase na divisa já.

V- Ali não é mata do...

M- É mata, mas lá em cima está na faixa do mapa da cidade que lá é área rural (risos)

V- Lá é rural?

M- Lá é área rural, porque lá ninguém vai criar nada. Então eu discutia muito isso com as autoridades.

V- Discutia? 
M- Discutia, eu criei a Associação justamente...

V- E qual foi o ano que se criou essa associação?

M- Noventa e três, noventa e quatro. É, noventa e três, noventa e quatro. Aí o que que aconteceu? Muitos começaram a pegar muito no pé porque mesmo com a associação...

V- E quantos associados você chegou a ter?

M- Tinha vinte e cinco associados que era só as pessoas que realmente mexia com os animal, né?

V- Que criava e matava e...

M- Que criava. Tinha vários, mas os vários não aderiram. Porque aí, por não aderir, a Associação não andou. Porque era eu sozinho e as pessoa dizia "Ah, mas Miúdo está fazendo a politicagem, Miúdo.." Não acreditava. Aí quando pensava que não, chegava lá a vigilância sanitária e os fiscal da vigilância sanitária, aí pra prender os animal, mandava tirar, né? E entrava no ministério público, né? Começava então, vinha no cumprimento da lei, aí tinha que desocupar. Aí dizia "Puxa vida, bem que o Miúdo falava.", falei "Olha, eu falava, vocês não acreditava!" Porque quando uma comunidade, ela se une em um objetivo, ela consegue, né? Até dentro da lei mesmo, fazer. A promotora, o promotor dizia "Olha, se conseguirem dentro da lei, se passar pela câmara um projeto, nós..." Mas olha, a câmara tem que fazer um projeto de lei, dizer "Olha, essa área aqui é rural. Então nessa área aqui você pode criar, nessa área aqui você pode ter animal. Nessa área aqui você pode ter criações." E não conseguimo. Mas aquilo ficou sempre dentro de mim. E aí começou outra atividade na cidade. O quê? Cavalo.

V- (risos)

M- Aí me chama "O Miúdo..”, aí começaram...

V- E como é que surgiu o cavalo?

M- Surgiu porque já é a história de Cubatão e muita gente tem cavalo na cidade.

V- Como assim? 


\section{M- E gosta.}

V- Porque assim, o pessoal às vezes que eu converso fala: "Começou a aparecer cavalo". Mas assim, do nada como se for, hoje, começou a criação de elefante, vamos supor. exemplo.

M- Não, né? Porque ele começou...

V- Como é que foi?

M- Porque o nordestino, ele vem de lá, é um vaqueiro. Tem o cara que (?) lá , ele trabalhava como vaqueiro. Então qual era a vida dele? Era no fim de semana estar montado num cavalo, ir para as festa, ir para a vaquejada, né? Então a finalidade do cavalo era esta. Ah, o outro, tem uma carroça, tem uma charrete bonita. Então, a finalidade era essa. E já tinha // não tinha os animal, mas tinha as pessoas que gosta dos animal e eles se sente, né? Faltando alguma coisa dentro dele, porque ele gosta de ter um animal, quem é que não gosta de ter uma galinha no quintal, né? Quem é que não gosta de ter aquilo da raiz dele. A raiz dele é o Norte e pela a raiz dele ele vai precisar de alguma coisa para sistisfazer o ego dele. Às vezes ele está sabendo, olha, "Poxa, eu não posso tem um cavalo de Cubatão, mas eu vou ter que ter um cavalo!". Porque dentro dele está pedindo que ele tem que ter um cavalo. Porque ele foi criado, veio o pai ensinando ele montar, o pai levando ele para a feira no lombo do cavalo. E aquilo está nele e é uma terapia para o corpo, para a mente. Aí começou. Aí começou, aí justamente e quem veio? A vigilância sanitária para tirar os cavalo da rua. Aí chamaram quem? Miúdo!

V- (risos) O salvador da pátria.

M- Você vê que nunca tinha tido desfile em Cubatão com os cavalo. Nós conseguimos colocar quarenta cavalos no desfile oficial.

V- Que ano que foi, mais ou menos, isso?

M- Olha, eu não tenho na mente, eu só tenho lá. Mas no dia em que você for... Mas é entre noventa... noventa e seis, noventa e sete, por aí assim. Quase a dois mil. Aí criei a Associação dos Cavaleiro de Cubatão. “(?) que esse cara é doido”, trabalhei dois anos organizando o povo. Mas no primeiro ano, quando a gente já estava começando, já botamos quarenta cavalo na avenida, desfilando. Isso foi uma 
história, ainda levava a cada bairro um evento. Até hoje o presidente da associação é o Eraldo, é o Eraldo que é o presidente, né? Que conhece, né? Que criou. E aí nós andava na cidade, ia para os bairro fazer festa, quando chegava lá, a mãe levava as criança, porque aí já vira (?). A mãe, ela montou no cavalo, e o filho nunca tinha montado. "Ah, bota aqui em cima do cavalo", entende? E ficava dando volta. Então tem uma // tem as fotografia também // tem uma história, né? Eu digo "Carambola!". Aí continuou, eu passei a associação para ele porque eu sempre faço as coisas, eu não faço visando política. Todos nós somos políticos, mas eu sempre faço vendo o lado cultural da cidade, vendo o lado cultural das pessoas, para que justamente amanhã ou depois...

V- E essas festas? Fala um pouquinho das festas.

M- As festas nós ia nos bairros. Então nós chegava na Água Fria, agendava um campo lá com o presidente da Água Fria e era "Domingo a Associação dos Cavaleiros vai estar aqui com os cavalos e brincadeira". Então tinha cavalo que deitava, cavalo que pulava, cavalo //né? Cada um cavalo fazia uma habilidade, pegava o (?) e vinha na charrete. Então era um dia de lazer, a finalidade prá justamente educar eles na cidade, criar um regulamento dizer "Olha, não pode andar tal hora, não pode andar na avenida Nove de Abril, não pode deixar o cavalo solto, tem que ter um médico cuidando, então um veterinário cuidando do animal" então, tudo isso para se organizar e dar até // gerar emprego! Porque você vê nas outras cidades, um cavalo, uma charrete// você vai numa cidade do interior, você vai pagar para andar de charrete.

V- De fato. Tem razão

M- Certo? Você vai pagar para andar. Você vai chegar lá, o seu filho, seu esposo quer dar uma volta "Ah, vamos dar uma volta aqui na cidade." Em vez de estar de carro, que carro (?) semana. Então, vamos num transporte diferente. Então, foi criada com essa finalidade. Mas aí o que é que aconteceu? Aí depois eu deixei na mão deles, porque eu não gosto de fazer política com nada daquilo que a gente monta socialmente e culturalmente. E a política é uma seqüência da vida. A política nós tamos (?) ela todo dia, né? Aí começaram lá e eu falei "Ah, então está bom." Aí me expulsaram como presidente porque eu não pagava a taxa de sócio. Olha, eu criei, trabalhei, investi. 
V- Ah...

M- "Ah, vamos caçar o presidente". Eu digo: "Cace o presidente!" Aí caçaram o presidente.

V- (risos)

M- "Caça o presidente!" Eu já tinha, assim, atingido aquele objetivo. Lógico que eu daria seqüência, mas eu daria seqüência sempre naquela mesma linha, organizando. Aí fala "Poxa vida" // Aí agora está todo mundo: "Mas rapaz, parou os eventos, parou isso" porque sempre eu pego uma coisa e eu levo até o final, né?

V- Tá.

M- Se alguém achar que eu estou errado, também se questionar e for tomar de conta, né? Mas eu não crio nada para mim, eu crio para a cidade. Aí parei. Deixei de mão e agora, né? Aí eu fui em 2001, aí eu parti para outra área. Quando uma começa área ruim, eu vejo que está fraca, eu digo "Perai, deixa eu quebrar a cabeça em outra atividade". Falei "Vamos ter uma Associação de Rádio Comunitária." Aí agora...

V- (risos) Uma figura.

M- Nós trabalhamos com a Rádio Comunitária, né? Justamente para divulgar os trabalhos da cidade, os trabalhos do bairro, né? Conscientiza a população, pegar as crianças para ler a Lei Orgânica, ler a Constituição, ler o Estatuto da Criança e do Adolescente. Então criei uma rádio comunitária como ela deve ser, comunitária para a comunidade.

\section{V-Tá}

M- Entendeu? Então fica lá os programa, né? E quando eu chego, eu vou lá estar fazendo todo aquela trajetória para que justamente a comunidade // Hoje eles fala "Puxa, tudo o que Miúdo põe a mão dá bons fruto.", né? Porque, às vezes, o pai e a mãe vê lá a criança lendo uma constituição// Quem já imaginou, uma criança com dez anos, onze anos, ela chegar ali estar sabendo os direitos dela. Lógico que ela não vai entender, mas ela tem que saber que um dia // e ela deixa registradozinho o nome dela lá no livro, a idade// que um dia ela leu aquilo ali. E um dia, se ela errar, 
ela fala "Poxa vida, eu errei porque eu quis. Mas aqui eu sabia, o Estatuto da Criança, o Estatuto do Adolescente, do Idoso". Porque nós temos que dizer para uma criança que amanhã ela vai ser idosa.

V- Está certo.

M- Agora nós engajemos numa outra campanha que é a da dengue, né? Hoje eu estava, ontem e hoje, começou de dezessete a vinte e um. Chamei todos os presidentes da Sociedade Melhoramento. Eu não sou mais o presidente da Sociedade Melhoramento.

V- Não é?

M- Não sou. Todo mundo que me chama, mas aí me chama eu vou lá ajudar. Chamei todos os presidentes, só que quem está indo lá sou eu. Aí nós ficamos (?) que é essa campanha aqui que nós estamos fazendo.

V- Ah tá. Da dengue.

M- Da dengue. Então esta é uma pequena história da minha vida de quando eu vim do Norte para cá, né? Aí tem mais, ainda tem os seis filhos, quatro netos...

V- Você casou quando?

M- Em 1980. Eu não casei não, sou solteiro.

V-Ah é?

M- Sou solteiro.

V- (risos)

M- Só tenho seis filhos e quatro netos.

V- Seis filhos e quatro netos. E você conheceu a sua esposa aonde?

M- Eu conheci ela trabalhando na área da Cosipa.

V- Ah. E ela trabalhava também lá?

M- Ela trabalhava lá na Cosipa. 


\section{V- Ah.}

M- E eu conheci assim sabe? Eu sempre fui meio dinâmico, e passou um dia de trabalho eu falei assim "Olha, se essa mulher fosse solteira e quisesse casar comigo, eu levava ela para o barraco." Eu já tinha um barraco no Pica-Pau.

V- (risos)

M- Aí quando eu cheguei // morava eu e meu irmão, né? Quando eu cheguei no outro dia, chegou um rapaz e falou "Olha, aquela mulher que você falou que se fosse solteira e você fosse solteiro // ela está sozinha. E se você quiser ela vai para o seu barraco." Eu falei "Então toma a chave" eu peguei e dei a chave..

V- Nossa! (risos)

M- È uma história, assim, que você não acredita. Aí cheguei em casa está ela, a mãe e uma filha.

V- Vixi

M- Que ela uma filha mais velha que é por // Quando ela fez quinze anos eu falei "Olha, se você quiser que eu registre você como minha filha, aí eu boto meu nome em seu registro de nascimento." Ela falou "Quero!" Aí quando ela completou os quinze anos, né? Hoje ela é casada, ela me chama de pai, né?

V- Olha, que maravilha.

M- Então porque, justamente, a trajetória de uma família. Eu já peguei uma filha, que já tinha, na época seis anos, né? E ela hoje é a filha que me dá orgulho.

V- Que bênção!

M- Não é filha do meu sangue, mas é filha do meu documento.

V- Claro.

M- É mesmo como se fosse minha filha. A coisa que mais me impressionou foi um dia, ela estava diante do pai dela, ela falou "Olha, o senhor é o meu pai de sangue, mas esse aqui é meu pai verdadeiro, que me criou, o meu pai que me deu nome. Este é o meu pai." 


\section{V- Olha!}

M- Ela falou para o pai dela assim. Então aquilo ali, para mim...

V- Foi tudo.

M- Né? É tudo isso. Então eu tenho mais seis filhos, três filha e três filho, né? E os quatro netos que eu já tenho agora.

V- Que bênção.

M- E a gente vive junto. Sou separado da mulher já tem dez anos...

V- Tá.

M- (risos) Nós somos separados tem dez anos e moramos no mesmo terreno!

V- Nossa e conseguem? (risos) Vivem bem, né?

M- Vivemo bem. Porque, veja bem, quando eu me tornei uma liderança, uma pessoa, eu sou muito chamado, entendeu? Estou num canto a pessoa me chama para outro, eu estou num canto a pessoa me chama para outro. Então // e ela achou que tudo que eu estava fazendo, para ela, eu estaria com uma mulher. Ela não sabia // Não é eu que quero, é uma missão que me dão, né? Eu não sei de onde vem, se me chamam eu tenho que ir. E eu estou vendo que eu não posso voltar. Se eu voltar, eu perdi aquilo que eu me tornei. Ainda que eu queira voltar, às vezes eu paro e penso: "Poxa vida, às vezes eu vivo mais para os outros do que para mim.".Mas eu vivo sastifeito, vivo alegre, vivo contente, então// Eu acho que não tem coisa melhor do que você se viver sastifeito com aquilo que você faz. E eu saí do Norte, né? Eu sofria muito, fui criado praticamente sem pai e sem mãe, mas eu aprendi a viver na vida. E agora, hoje, eu estou ensinando aquilo que eu não fui ensinado.

V- Entendi.

M- Entendeu? Então eu ensino, se eu contar e se você sentar, tem que ser um dia, né? Para você ver toda a trajetória. Em quem você chegar aqui na prefeitura e perguntar "Miúdo ?", tem aquele que vai dizer "Olha, Miúdo é sem futuro, Miúdo não presta". Mas porque alguma coisa de boa eu já fiz para ele. Né? Porque a gente não vai agradar cem por cento. Eu sou verdadeiro. Se você estiver errada eu vou dizer 
para você, olhando nos seus olhos, "Você esta errada, Vilma". Se eu estiver errado você tem que dizer "Miúdo você está errado". Não adianta você depois que sair daqui, você dizer em tal lugar. Então esta é a essência do cidadão. É a essência do ser humano, ele tem que olhar um para o outro e dizer "Olha, está errado aqui". Então tem essa dinâmica com os prefeitos que está, com os outros prefeitos que passaram. Então eu sou meio polêmico, mas sou um polêmico com visão para uma cidade melhor, para um país melhor, para um estado melhor, para tudo melhor, porque quando eu for embora eu sei que alguém vai cultiva aquilo que eu deixei plantado.

V- Sim, vai continuar o que você iniciou, né?

M- Iniciei. Aquele que falar "Poxa, olha, às vezes nós não fizemos tudo o que o Miúdo falou, mas ele falou para gente fazer. Tentar, pelo menos, fazer." Porque não custa nada você tentar, não custa nada você sonhar.

V- Sim

M- Agora não custa muita coisa se você quiser fazer a ferro e fogo e pontapé. Vila Esperança, hoje é que eu estou fazendo coisas de bloco. Todo mundo já tinha feito. Agora que eu estou começando depois de vinte anos. Eu planejei Vila Esperança, adonde eu moro vinte anos, eu agora estou planejando para quem? Para os meus netos, porque meus filhos já estão criados. Então cada o filho tem um lugar para ele morar. A área não é minha, não. A terra não é de ninguém. Alguém // alguém faz um documento para ela. Porque se fosse dono todo mundo, então quando morresse, levaria com ele.

V- (?)

M- Não é isso?

V-Sim.

M- Então, veja bem, nós temos uma lei que os homens criaram, que justamente para o que é meu. Lógico que vem de muitos anos, mas todo o ser humano, todo o cidadão, ele tem um espaço garantido por Deus na Terra. Quando Deus chamar, vai ter uma gaveta. Aqueles que vai para a gaveta, vai para a gaveta, e aqueles que não for achado? Para onde vai? Então, tudo isso são coisas que a gente temos que estar 
passando para geração em geração, porque você vê o mundo, hoje, ele está, quanto mais se aperfeiçoando a tecnologia, mas esquece a cidadania do dia a dia de cada ser humano. Porque não adianta dar para uma criança, hoje, um celular. E se ela chega em casa, no outro dia e não tem um pão para comer? Não adianta dar uma televisão colorida, se na casa dela não tem um leite para ela beber. Então eu acho que tem que fazer o quê? Dividir a tecnologia com emprego, o salário digno para cada cidadão, né? Porque todo o cidadão vai ter aí o seu pãozinho, né? E ensinar, ensinar que um pão e um bolo bem feito é o mesmo valor de uma espiga de milho ralada no ralo e feito um mingau para a criança comer. Às vezes é mais forte do que aquele pão que foi feito com fermento. Porque às vezes as pessoas falam: "Poxa, mas vamos voltar ao passado?" Não, mas o passado é o presente. Porque você tem uma história dos seus pais, dos seus avós do seu bisavô. Ou não tem?

V- Tem.

M- Você tem?

V- Tem.

M- Que queira ou que não queira, amanhã ou depois, uma comida que seu bisavô comia, ela vai sastifazer você hoje, depois de muitos e muitos anos, do mesmo jeito que fazia o seu bisavô.

V- Sim.

M- Então é isso é o (?) Você fala: "Mas o passado", Não, o passado está presente. Nós não podemos justamente esquecer o passado, para justamente o presente estar sempre coligado com o passado. Porque você não pode esquecer o seu pai, não pode esquecer a sua mãe, sua avó, sua bisavó e hoje está se perdendo. Hoje você vê o jovem passa por junto do pai, passa no meio.

V- É. Espera só um momentinho.

\section{CORTE NA FITA}

V- Então, continuando...

?- Com licença (?) 


\section{M- Boa tarde}

?- Boa tarde (?)

V- (risos) Então, só para fechar, você falou bastante da sua trajetória, né? De vida profissional, que você começou a criar o porco, que você fez o pão, né? Aí montou a Associação dos Cavaleiros, né? Isso aí a gente vai ter que voltar um pouco, agora nessa semana ou semana que vem, rapidinho, assim, para a gente tentar entender, né? Porque eu gosto de conversar com calma.

M- Vamos para ali, vamos sentar ali que aquele (?)

V- Vamos. Então, mas Miúdo, assim, voltando a essa questão da Associação, você me explicou, você conseguiu me explicar por que que surgiu o cavalo, né? Aqui, porque as pessoas gostam, as pessoas tem raiz, né? Agora, tem um problema com a prefeitura, né?

M- É, o pobrema é justamente// não é com a prefeitura, é com as leis da prefeitura. O prefeito é a favor, é só depende da câmara entrar com um projeto de lei que essa área aqui seja rural. Então, se esta área for rural, pode-se criar. Porque aí tem como você prender // você não pode prender o cavalo, porque não tem a lei.

V- Sei.

M- Entendeu? Então o problema com a prefeitura é justamente esse, porque ela não tem nada dentro da lei que ela possa prender, que ela possa...

V- Mas quem criou essa lei?

M- Porque ela não existe.

V- Não existe?

M- Não existe.

V- E por que que não se cria essa lei?

M- Justamente, porque falta uma pequena vontade deles. Porque quem é que tem que criar a lei? É eles! Eles tem que criar uma lei que realmente permita que as pessoas possa criar. Se não tiver a lei que esteja permitindo você criar, você tá 
criando clandestino. Aí quando é denunciado, você tem que fazer o que? Simplesmente ir lá e dizer "Olha, eu estou criando uma coisa clandestina, porque a cidade não está dando estrutura para que ela tenha, dentro da lei, um espaço para que possa ser criado. Então o problema na prefeitura é esse, é falta de lei para amparar o cidadão.

V- E aquela lei? // Porque me falaram que é uma lei de oitenta e três, que é essa proibição que o cavalo não pode circular. Eu preciso ver essa lei.

M- Eu tenho lá no// Eu acho que eu tenho lá // Quando eu montei a Associação, quando eu montei a Associação eu peguei, né? Que eu fui buscar tudo da lei. Porque a lei que eles estão aí, justamente // eles criaram uma lei para você não trafegar na cidade.

V- Tá.

M- Então quando eles criaram a lei, mas já existia os animal. Quando eles criaram a lei já existia as pessoas que gostam dos animal. Só que eles criaram a lei porque para que o cidadão // é mais fácil de dizer não do que dizer sim. Você chega na minha casa com um problema, eu digo não para o seu problema. Mas seu eu disser "Vamos tentar resolver" eu vou ter um pouco de trabalho para resolver o seu problema.

V- Claro.

M- Mas se eu disse "Olha, não quero nem saber". Talvez eles cria a lei para não assumir aquilo que eles são. A nossa cidade ...

V- Perfeita a sua colocação.

M- Certo? A nossa cidade, ela tem que ter uma lei para ajudar o cidadão. Ah, no centro não pode. Mas se você tem uma lei que lá no ponto final da Vila Esperança tem uma área rural e todos os animal tem que estar lá, aí está dizendo "Olha, você tem o seu espaço para você usar. Só que você não pode usar no centro da cidade." Mas você tem um local para você usar. Então quando você tem não tem um local para você usar, então você pode usar em qualquer lugar, porque você está clandestino. 


\section{V- Entendi.}

M- Entendeu? Porque toda cidade tem um espaço, você em Praia Grande, na beira da praia, usa-se uma vaquejada. Itanhaém tem, Manganguá tem, São Vicente não tem // onde corre os cavalos, como é que é o nome?

\section{V- O Jockey?}

M- O Jockey. Então aqui está um (?). Então vamos supor que esse cartão daqui é um espaço para os cavaleiros, "Olha, cavalo só pode ser criado no sítio, na cidade, nada". Mas como não tem lugar para // você não pode nem criar nem no sítio, nem na cidade, então deixa ele clandestino na cidade. Porque tanto foi ele estar aqui na cidade que nem tem lá no sítio. È a mesma coisa.

V- Está tudo clandestino.

M- Adonde ele estiver ele está clandestino.

V- E você acha que aqui tem local para...

M- Tem!

V- E depois eu quero conversar com você sobre isso, porque para a gente pensar em alguma coisa nesse sentido...

M- É, justamente porque tem ...

V- Para entender também a realidade, sabe?

M- Porque você vê, tem um projeto de lei que deve estar tramitando, que é obrigatório todo o município ter uma terapia animal para crianças especiais.

V- Sim.

M- Né? Então, por que existe o horto? O horto existe porque lá está os animal, o parque ecológico, lá está // Você pode ter medo de uma babuleta, mas pode não ter medo de um elefante, e aí? Então você vai ter que conviver com o elefante e com a babuleta, para você, a sua mente, a sua mente, ela se adaptar a uma babuleta. Porque que bicho sensível é uma babuleta? Mais perigoso é um elefante ou uma babuleta? Claro que é o elefante. Mas às vezes você não tem medo de um elefante, 
mas tem medo de uma babuleta. Tem uma senhora lá, que trabalha comigo na rádio, ela pode ver qualquer bicho...

[Buzina]

?- (?) (risos)

V- Continuando aqui!

?- Tá bom.

V- (risos) Obrigada!

M- ... pode ver qualquer bicho, mas se ela ver uma babuleta, ela desmaia. Você acredita nisso?

V- É mesmo?

M- Uma babuleta. Assim, dentro da rádio, entrou uma babuleta amarelinha lá, essa mulher deu um grito que eu pensei que tinha caído ou ela tinha tomado um choque. Cheguei lá dentro, uma babuleta que chegou, entrou e pousou. Agora você vê, então na nossa vida, nós temos que adaptar a todos os segmento. Porque, você vê, se fosse uma cobra ela não tinha medo, se fosse uma barata ela não tinha medo. Então ela tem que se adaptar a perder o medo de uma babuleta. Porque uma barata não é pior do que uma babuleta?

\section{V- Com certeza.}

M- Você vê, ela não tem medo da barata, mas tem medo da babuleta.

V-Senhor.

M- Então eu estou te falando isso para você chagar// pega uma babuleta e passa por perto dela. Se ela ver a babuleta, ela faz de tudo para se esconder. Então é a nossa cidade, eles se esconderam de uma coisa que a cidade tem raiz. Porque a cidade de Cubatão era rural. Ela era rural e ela continua, sempre, sendo rural. Por que? Porque a maioria que está aqui são nordestino. O camarada não cria um bode aqui, mas ele cria na cidade vizinha. E aí?

V- (risos) É, de fato. 
M- Então você vê que a cidade está excluindo a própria cultura dela. A própria cultura dela, porque aqui // isso aqui era tudo bananal. Isso aqui o gado andava no meio da rua, falava os antigo morador de Cubatão, né?

V- Sim.

M- Porque eu convivi muito com eles, com seu Chicão, que conheceu do primeiro prefeito, de como a cidade era. Então, o que eles fala está tudo em documento. Porque a cidade já era um povo colono, era um povo rural, era pessoas que sobrevivia de quê? Do lombo do animal. Aí você ouve lá: "Ah, Cubatão não pode ter um cavalo. Ah, Cubatão não pode se criar uma vaca para tirar o leite. Ah, Cubatão não pode se criar um bode, não pode se criar uma cabra. Cubatão só tem que ter indústrias." Não, ela tem que ter indústrias, mas tem que ter ali// você pega o espaço, cria uma mini fazenda, ela gera renda e gera terapia para aqueles que, às vezes, estão aí agoniado com a sua mente "Ah, vamos ali na fazenda buscar um litro de leite." Só que ali na fazenda tem que ter um veterinário, tem que ter a comida balanceada, cuidada e tratada. Não ter por ter, tem que ter a coisa organizada dentro da lei. E aí quando você não organiza dentro da lei, tão aí os bairros cota, está aí Vila Esperança.

V- É, tem os bairro cota, Vila Esperança

M- Tem a Vila dos Pescador. Aí acontece uma tragédia, por que aconteceu a tragédia? Porque eles não se preocuparam em pranejar a cidade. Mas não adianta dizer: "Hoje nós vamos pranejar a cidade." Hoje não, a cidade já tem que estar sendo planejada. Há vinte anos. Porque há vinte anos eu entrei aqui dentro desse bloco cultural e disse para o prefeito, na época, que ele estava errado. Mas levou vinte anos para ele entender que ele estava errado. Porque se ele tivesse me escutado há vinte anos, hoje não estaria errado.

V- E não estaria essa dificuldade, né?

M- Essa dificuldade. Então hoje, o maior arquiteto, o maior urbanista, ele não consegue dar uma dinâmica nessa cidade. Porque ela está feito uma casa de marimbondo: ela está lá quietinha, não está quietinha? Se você passar e balançar o galho, ela não vai te morder. Mas se você balançar o galho, vai sair dali de dentro um monte de marimbondo que vai lhe morder. (?) pegou fogo na casa dos pescador. 
V- É, pegou fogo lá na Vila dos Pescadores.

M- Pegou fogo lá. Aquele fogo lá já estava previsto? Claro que estava previsto, porque é tudo de madeira, fiação a bangu, então aqui, tipo, passa-se quatro anos, mais quatro anos "Ah, estamos tentando arrumar." Mas enquanto estamos tentando arrumar, os quatro anos, se você partir para uma dinâmica, tem muito dinheiro sobrando, busca um projeto social, vai constrói uma república com cem casas. De quem é? Do município. Para quem é? Para atender qualquer emergência no município. Aí acontece uma emergência no município, você vai colocar aonde? Ah, no colégio. No colégio tem as crianças estudando. Ah no poli esportivo. No poli esportivo é os atreta. Então a cidade// Quando eu estava no Norte, eu ia para o Sul cortar cana. Chegava lá no Sul tinha cinqüenta casas, uma atrás da outra.

\section{V- No Sul de Pernambuco?}

M- No Sul de Pernambuco. Nas usina! Isto, né? Há quarenta anos passado. Quando a gente chegava lá "Está aqui, olha, sua casa, seu fogão, sua cama, o lugar para amarrar sua rede, para armar sua rede, então você estava ali.

\section{CORTE NA FITA}

V- Então continuando. Você estava falando da Vila dos Pescadores que aquilo tudo já era [falha na fita] por causa de uma falta de planejamento, de vontade política, né? Que não atende a necessidade da população.

M- Não atende. Aí Vilma, o que que acontece? Veja bem, depois que o fato acontece, aí querem tomar providência. Só que é uma providência (?). Eu sempre falo. $\mathrm{Na}$ área da saúde se reúne as cinco esfera, né? Para dar uma boa saúde. Prefeito, câmara, polícia, porque aí envolve tudo na área da saúde, é uma segurança. $\mathrm{Na}$ área da segurança envolve as cinco esfera e a comunidade. Então o que que acontece? Justamente, quando as autoridade, ela se aglutina para buscar uma qualidade de vida melhor, ela traz saúde, traz emprego, traz segurança, traz tudo aquilo que o cidadão precisa. E traz o principal: é a ordem e o progresso. Porque depois que a coisa estiver complicada, não adianta querer resolver. Porque você só vai lidar com uma população que está inflamada e não vai resolver o caso. Nós temos a Água Fria. A Água Fria nós tem população lá que já tem quase trinta anos morando lá. Aí chega lá um cidadão e fala "Vamos tirar aquele povo de lá." 
Colocar aonde? Dar a ele um bloco público para ele pagar // Ele já está há quarenta anos no local. Então vai botar mais vinte e cinco anos, trinta anos para ele ficar pagando um predinho do CDHU. E lá ele está acostumado lá a criar uma galinha. Quando não tem a mistura, ele vai lá, pega um ovo, frita, come.

V-Tá.

M- Ele vai lá, mata uma galinha. Chega uma visita, ele não tem o dinheiro para comprar a mistura, ele mata uma galinha, um frango, ele come. Então ele // ele não está dependendo só do salário. Que quando tem é bom e quando não tem? A nossa cidade é uma cidade das mais ricas, mas se nós analisar, ela a da mais pobre. Porque mais pobre? Porque ela tem muita lei e a lei não favorece o cidadão. $E$ quando a lei não favorece o cidadão, ele fica travado. Aí eu não posso criar um porco porque a vigilância vem sanitária e me prende. Aí eu não posso criar um cavalo às vezes para ir a um passeio, porque vai ser preso. Mas e eu tenho o dinheiro para pagar o carro, a condução? Aí ele vai vir aqui fazer o quê? "Ah, você é vereadora, me arruma aí o dinheiro da passagem". Você arruma o dinheiro da passagem um dia. E quando pensar que não, ele se torna um vício. Aí depois ele vai vir para você pagar a conta de água, ele vai vir para você pagar a conta de luz, ele fala "Puxa, mas minhas criança queria ir na quermesse com um brinquedo. Eu não tenho dinheiro. Puxa dá para você?" Então se torna um paternalismo que depois não tem como desafogá-lo. Então qual é o primeiro passo? Emprego e um salário digno para cada cidadão ou cidadã maior de dezoito anos. Ah, o jovem está dando problema? Está, então vamos pegar quem está aposentado e abrir um espaço de capacitação para o jovem. "Você gosta de ser o quê?" "Ah, eu queria ser soldador." "Então está bom. Está aqui fulano de tal que vai lhe ensinar você a soldar. E você, qual é o seu dom? O que é que você gostaria? Está aqui, olha, soldador, carpinteiro, eletricista, encanador, marteleteiro, serralheiro." Porque todo mundo não vai ser advogado. "O que que você quer?" "Quero essa função" "Então está aqui, vai aprender", Três meses de curso ganhando um salário. Ganhando um salário! Mínimo, para estudar e aprender uma profissão. Terminou, (?) empresa. Aonde é? "Olha, está indo um jovem aí que se qualificou com seu certificado, dá um pequeno teste para ele, vê se ele está aprovado." Bota ele na empresa. Você começa // Sabemos que é difícil, claro que é difícil! Mas se planejar, você vai alimpando a cidade. "Ah, não tem como criar emprego não." Então vamos pegar esse espaço 
aqui e criar um espaço turístico para atrair os turistas. "É o que?" Então aqui você vai gerar duzentos, trezentos emprego, informal ou formal, mas organizado. Vende um cachorro-quente, o outro vende lá uma rapadura, o outro vende lá uma tapioca, o outro vende um caldo de cana. Não pode você vender tudo não, cada um vende uma coisa. Que aí você faz um ciclo de emprego. Gera. No meio-ambiente, então vamos criar as trilha. Jovem, jovens em vez de estarem aí ansioso a trabalhar// Ah não, quando o jovem está ansioso vai lá numa empresa para trabalhar. "Em que você já trabalhou?" "Em nada" "Que que você já fez?" "Nada". Porque você pergunta para ele, ele vai lhe responder o quê? Nada. Porque ele não sabe de nada.

V- Não tem experiência nenhuma.

M- Chega no colégio, você pode parar aí na frente desse colégio aí, sete oito e meia da noite. É tudo jovem adolescente, dezessete, quatorze, quinze, dezessete, dezoito, e pergunta pra ele "Você conhece a sua cidade?" Aí ele vai dizer assim: "Não." "E o que que você acha da sua cidade?" Ele já vai falar "Ah, a minha cidade não presta. A minha cidade não tem isso." Mas ele não vai falar que ele não faz que a cidade dele tenha tudo isso.

V- Não vai atrás, né?

M- Porque se ele fizer com que a cidade dele tenha tudo isso, será a melhor cidade. Porque a cidade quem faz é você que mora nela. É cada um da população. Então você deixa ela a bangu, cada dia mais é que nem está o negocio do país hoje, você vê aí a violência do país. Por que a violência está assim? Porque deixaram o formigueiro crescer, deram muita asa e hoje querem cortar asa. E consegue cortar? Não consegue cortar a asa. Hoje o dono de casa sai preocupado, o empresário sai para a empresa dele, sai preocupado. Porque você está vendo o que está acontecendo e tudo é mídia, televisão, televisão, televisão. Então eles estão vendendo aquilo próprio que o país criou, que não era para estar vendendo. Você liga a televisão está lá a moça sendo julgada. Isso aí ninguém fala. Não, está lá, quando ligar a televisão tem que estar lá um programa educativo. Como se gera um emprego, né?

V- Sim. 
M- Como cidadão amanhã ele tem que respeitar o outro. Quando você liga a televisão hoje, os maiores canais, é o que? Aí o cara fala "Mas o Datena fala a verdade." Não. Ele ganha para fazer aquilo que o povo não está entendendo, que está sendo uma miséria do que ele está falando, porque se aquilo está escondido// O preso, quando sai do fórum, sai a polícia, sai rasgando, todo mundo sabe, mas foi um preso que saiu do fórum. Saiu, tem que entrar e sair sem a população saber qual foi o dia que teve o julgamento, qual o foi o dia que teve tal coisa porque a cidade// mas ela sabe, todo dia às cinco e meia sai o julgado do fórum.

V-É mesmo?

M- Aí a ambulância sai rasgando com dois carros de polícia "Uau uau uau uau uau uau"

V- É assim?

M- Você está dizendo que, que está dizendo, que está ali de dentro? Então você chega lá fora do fórum, está todo mundo guardando a porta do fórum adonde é a justiça. Mas tem que estar cercado, trancado para você não poder passar. Porque criaram, as cabeças pensante, as autoridades do país criaram tudo isso. $E$ hoje, através do que eles criaram tudo isso, Vilma, o que que acontece? Querem dar reviravolta. Não vai, não vai conseguir. Por que não vai conseguir? Porque a população já se aviciou demais. Então vai ter que dar um choque para trazer ela para a ordem. Qual é o choque? Você bota aí todas as lei e as autoridade na rua, aí vai começar o país a se organizar. Porque você, hoje, não se sente // Quando você está num canto, você olha pra lá e para cá, quem é que está vindo, quem é que está indo; quem é que está passando; se você conhece, se você não conhece. E hoje tudo o que a gente vê, a gente há trinta anos não via, há quarenta anos passado não via. Mas era (?) não. Quarenta anos era mesma realidade de hoje. Quando eu cheguei em Cubatão essa árvore estava plantada. E ela está aqui hoje, ela só tem uma idade, mas ela está aqui. Hoje você vem e planta aqui as árvorezinhas pequenas. Quando é depois de amanhã, as árvores não tem mais nenhuma, aquelas proteção (?) já arrancaram tudo. Quem arrancou? E ninguém viu? Ninguém sabe? Claro que sabe. Mas deixaram fazer. É o nosso processo de Vila Esperança, da Água Fria, da Cota. E o povo não tem nem comentado. Sabe o que é você morar 
num bairro de vinte mil pessoas, ter setenta caminhos e não passar um carro? Aí eu na minha casa guardo dez carros.

V- É mesmo?

M- Eu, na minha casa, passa uma estrada que passa um carro desses, vai faz o balão no meu terreno. E todos não tinha esse terreno? Todos tinha. Todos disseram "Não, vamos vender para ver se nós enrica" Enricaram? Não, estão pior do que eu. Por que estão pior do que eu? Porque os filho do bairro tudo se perderam. $E$ os meus eu plantei e pedi a Deus, primeiro a ele: "Cuide da minha família, que eu vou tentar cuida dos meus vizinho."

V- Fez bem.

M- Não é isso? Eu planejei. Quando eu falo essas história, todo mundo fala "Pô Miúdo" Não, porque se você plantar um pé de árvore, cultivá-lo, ele vai dar bom fruto. Agora se você não cultivá-lo, se você não organizá-lo...

V- Está na Bíblia, né?

M- Você deixou // plantou o pé de batata "Ah, vamos deixar aí." Batata é que você coloca no chão, deixa ela enramar que ela faz uns brotinhos. Porque ela já é batata e já é enramada. Mas outras coisas tem que cultivar, tem que zelar, para que faça coisa. Então, nossa, // principalmente nossa cidade, era para ser uma cidade mais melhor. Porque ela não está melhor? Porque por coisas simples, coisas simples que não são difícil de fazer, a lei não deixa fazer.

V- É.

M- Nós tinha uma creche, na Vila Esperança, que atendia cinqüenta criança. Aí a creche foi fechada dentro da lei. Mas lá tem vinte mil pessoas que está irregular, fora da lei. Mas o cidadão chegou no Ministério Público, enfiou uma representação, porque a creche não tinha um filtro.

V- Um filtro?

M- Um filtro.Aí a moça que dirigia a creche foi lá, contratou um advogado, depois veio mais outro,// Eu sei que ela contratou cinco advogados. E eu cheguei para ela e falei "Senhora, a sua creche vai se fechada!" "Não vai" "Vai." "Não, porque eu faço 
um trabalho social..." "A senhora pode fazer o melhor trabalho social, mas a lei diz que ela tem que ser fechada. Porque o cidadão reivindicou, dentro da lei, que sua creche fosse fechada porque não tinha um filtro d'água." E o cidadão do próprio bairro. Se o cidadão tem ido lá e comprado o filtro...

V- Tinha feito melhor, né?

M- Não tinha feito melhor? Mas ele achou melhor, para aparecesse, politicagem. Quem perdeu? As criança. Então você vê lá, nós temos curso de inglês, patrocinado pela Terracom há cinco anos...

V- É? Que beleza.

M- Temos vinte computador, patrocinado pela Petrobrás (?) Governo Federal, agora estamos montando uma biblioteca. Temos uma rádio comunitária, que sabemos que está fora da lei. Eu sei que ela está fora da lei, eu tenho consciência, mas é fora da lei que eu estou tentando dar o que a lei não dá.

\section{V- Claro.}

M- Porque se a lei fosse lá, me visitasse, olhasse meu trabalho, olhasse tudo que eu faço, diz "Está aqui uma permissão para que você faça, como cidadão, um trabalho aqui. Está aqui. Tome, uma carta. Tome uma autorização." Mas ela pede tanta documentação para mim botar ela dentro da lei, que não compensa fazer tudo aquilo que realmente é preciso dentro da lei.

V- Inviabiliza, né?

M- Inviabiliza. Então eu sei que eu estou fora da lei, mas eu estou me baseando em quê? Eu estou me baseando no meu nome, estou baseando na minha comunidade, estou me baseando nas autoridade, que estaria para favorecer a ordem e progresso e estou munido de documento, porque se eu for preso amanhã "Ah, estava com uma rádio pirata." Mas não era pirata, pirata é aquilo que eu sobreviveria dela e não faria nada para a comunidade. Só de fotografia eu tenho aí três álbuns com quatrocentos e oitenta fotografias.

V-É? 
M- Da história do bairro. De cada criança que faz uma coisa, de cada criança que aprende a idéia de uma coisa. Sei lá, temos três livros no bairro.

V- Parabéns.

M- Porque um dia um delgado chegou para mim, eu com toda a minha inocência, e eu tinha guardado um objeto do cidadão. Mas eu guardei, você chega "Miúdo, me guarda esse gravador." Eu vou guardar. Se daqui a dez anos você me pedir esse gravador, eu tenho que dizer o quê? "Olha, Vilma, seu gravador está aqui.". Se ele estiver empacotado, eu não sei o quê que é, não vou abrir, não é meu! E era uma máquina fotográfica roubada e eu assinei um 180, receptação.

\section{V- Misericórdia!}

M- E eu cheguei para o delegado, tem mais de dez anos passados, tem mais de dez anos que eu ainda tenho o código penal em casa. E perguntei para ele "Mas doutor, o que é isso que eu estou assinando?" ele disse: "Você é um ladrão". "Mas doutor, eu sou um ladrão?" "É”. Está bom. Mas e eu pedi as informação e ele não me deu. Eu saí batendo na cidade, na cidade não tinha nenhum código penal, eu fui em Santos, comprei um. Está lá. Eu já tinha mostrado eles para varias autoridades aqui. Está aqui, olha. Eu melei meus dez dedos inocente, porque o cidadão que estava na cadeira, ele tinha um diploma, ele achou que eu tinha que assinar. Todos eles já foram embora. E eu estou aqui. E o código está lá, o código penal está lá. Eu digo "agora eu vou criar minha filha." Então eu passei por umas barreira, mas as barreira que veio foi mandada por Deus para eu ir aprendendo.

\section{V- Entendi.}

M- E hoje eu chego junto do prefeito, falo para ele, se for governador eu chego e falo, se o coronel da polícia vier aqui (?) eu falo para ele. Porque eu tive que aprender aquilo que eu não aprendi, que eu não tive oportunidade// $\mathrm{E}$ eu só sei ler, sabe até o que? Até a quarta série. Nem escrevo bem, nem leio bem. Mas eu faço um trabalho, não é porque eu quero fazer. É porque alguém toca dentro de mim e diz assim "Você vai ter que fazer e vai ter que aprender e vai ter que falar!" Então toda a trajetória do meu bairro, da minha cidade, que adonde eu chegava // Hoje você chegando em qualquer canto da cidade, se você perguntar 'Você conhece Miúdo?"Alguém vai dizer que conhece. 


\section{V- Sim.}

M- Porque // Não é porque eu quero, não é porque eu quero ser melhor do que os outros. Eu não sei, eu só sei que eu tenho uma missão. Quem me determina e quem me dá ela...

V- É Deus, né?

M- Não é isso? Se eu fosse outra pessoa, eu estaria conversando com você esse tempo todinho?

V- Pois é.

M- Se eu quisesse, estaria?

V- Eu acho que // difícil alguém...

M- Difícil alguém ia parar junto de você para, justamente né? Porque eu quero // Não! Se a gente dizer "Olha, meu Deus, vamos até lá, eu vou te mostrar." "Miúdo, tal dia eu vou vim." Um cidadão lá da Cantareira, da Serra da Cantareira, ele está fazendo faculdade de radiofônica. E ele bateu todas rádio comunitária para fazer um trabalho de rádio comunitária na faculdade.

V- Interessante.

M- No estado de São Paulo. Ele chegou lá, aí o presidente da ABRASP falou "Olha, você vai procurar um rapaz um Cubatão e você vai conhecer ele e você vai lá na casa dele. Ele vai te dar tudo o que você quiser para o seu trabalho."

V- Que bênção!

M- Aí ele veio...

V- (?) de graça (risos).

M- (risos) Ele veio, ele levou material. Semana passada ele ligou. Falou "Olha, Miúdo, eu acho que já estou pronto!" Porque ele aprendeu coisas que ele // na faculdade ninguém nunca ensinou a ele. Eu tenho um professor Sílvio, da UniSantos que vem lá da // faz um programa na rádio, vem a faculdade Marquense, né? Na parte da elegia, essas coisas. tudo vem lá conversar comigo. Eles são os 
professores, vem lá "Miúdo, eu vim aprender um pouco contigo porque // toda a trajetória." Até agora, essa semana, a TV eleitoral esteve aqui para fazer uma reportagem. Eu nem tinha visto no jornal, quando foi hoje, todo mundo "Olha, Miúdo, você viu que no jornal..." eu falei "Não". Aí eu fui, peguei, estava o jornal contando a história. Porque eu levei a repórter lá dentro do bairro para ver o que estava acontecendo.

V- Tá.

M- Então a nossa trajetória, para que a gente ter uma raiz de lá para cá, nós temos que tentar manter aquela raiz, tentar manter aquela árvore e quantos anos eu sei que eu vim do Norte. Eu hoje, depois de vinte cinco anos eu voltei no Norte. Depois de vinte cinco anos que eu estava aqui eu voltei.

V- Nossa, tudo isso?

M- Assim. Depois de vinte e cinco anos que eu voltei, eu amostrei para as pessoas quem foi mais eu, adonde eu tinha trabalhado, o que eu tinha feito e adonde eu estava. Eu parei em frente à Usina Tiúma, que hoje está fechada, e tinha um senhor tirando, alimpando a cana. Eu falei "Adonde está aquele senhor, eu limpei aquele mato a tantos anos passados. A cana não é a mesma, mas a plantação foi feita no mesmo local".

V- Claro.

M- Digo "Olha, eu vou ficar aqui no carro e vou dizer para vocês aonde está a medição e como é o sistema que ele vai tirar. Vai lá e conversa com ele. E eu vou ficar aqui, olha." Fiquei parado na beira na frente do carro aqui e eles desceram do carro, foram lá conversar, eu falei "Olha". Eu fui numa usina, que eu trabalhei cortando cana, e amostrei para eles tudinho, então eu fui fazer uma retropecstiva daquela vinda do Norte para cá. E eu voltei com vinte e cinco anos, voltei em todos os local que eu tinha passado como criança, como adolescente, como jovem, fui...

\section{FIM DO LADO A}

M- (...)Começar a beber muita cachaça. Aí eu levei ele para casa, recuperemos ele, aí ele foi embora para o Norte, né? Foi para a Usina Curangi. 


\section{V- Curangi?}

M- Curangi, a usina Curangi. Aí ele me ligou e falou "Olha, eu estou trabalhando aqui na usina e queria que você, quando vir no Norte vim aqui me procurar." Eu saí daqui eu falei "Olha, nós vamos hoje na casa do João Fagundes." Vamos lá. Eu sei adonde é. "Mas quanto tempo é?" Saímos daqui, passemos, fui na casa da minha mãe, passemos uns três dias, agora "Vamos visitar o João.". Aí quando cheguemos lá, aí ele tinha casado, estava com três filhos. Aí, quando cheguemos lá, eu mandei o povo lá, né? Conversar com a mulher dele, né? Falei "A casa é aquela ali, pergunta se não é ele que mora aqui, assim, assim, assim. Vai lá!" Aí eles foram lá "É aqui mesmo." Ele não estava em casa, ele tinha ido para a usina. Aí, nós ficou lá esperando e a mulher ficou assustada, né? Eu falei "Olha, quando ele chegar aqui, a senhora não fala que eu estou aqui. Fala que chegou alguém aqui, veio buscar ele preso" (risos). Aí, quando ele chegou da usina que ele estava trabalhando, ela falou "Olha, veio um povo de São Paulo aqui te buscar, porque disse que lá você deixou uns quatro filhos lá..." Inventaram aquela, né? Aí ele "Ah, mas eu não fiz nada disso, não, não (?) Falou "Olha, e você conhece o rapaz que estava aqui. Você conhece um rapaz lá de Cubatão chamado Miúdo?" Ele falou "Miúdo? Não, mas Miúdo não vai vim aqui" E eu lá trancado dentro do quarto dele, né?

V- (risos)

M- A mulher // fizemos amizade, mostremos que levei umas fotos dele. $\mathrm{E}$ a gente trancado e a mulher fazendo que estava desesperada, falou "Olha, e eles vão voltar aqui". Aí ele falou "Ah, então põe o almoço, que eu vou almoçar e vou dar um jeito, se eles chegar aqui eles vão embora, eu não estou aqui mesmo e vão embora." Aí quando ela pos o almoço, ela sabia que nós já estava lá, nós íamos almoçar. Ela botou o almoço, né? Começou a botar os pratos "Ah, por que está pondo os pratos?" "Não, porque você vai ter uma surpresa, né? Você vai ter uma surpresa na hora do seu almoço." Ele falou "Que surpresa?" "Esquenta a cabeça não." Aí quando ela botou, ela foi lá, ela abriu a porta do quarto, nós saímos de dentro do quarto morrendo de dar risada. Aí ele foi lá, abraçou, para você ver...

V- Que felicidade. 
M- Que felicidade ele estava, né? Fomos lá conhecemos os filhos dele, conhecemos a família dele e aqui ele estava jogado. Aqui ele estava jogado. Ele voltou para a terra dele, voltou, se recuperou e construiu a sua vida. Então, eu acho que essa cultura nossa, os imigrantes, os nordestinos, ela tem sempre que ter uma raiz, uma base.Qual é a base? É você não esquecer de onde você veio. E falar para os seus filho. Lógico que todos eles não vão ser igual, mas se você foi lapidando, for lapidando, for lapidando, eles vão pegando aquela raiz da família e eles vão fazendo a coisa acontecer, porque amanhã eles vão ser pai, depois vão ser também avô e vai na seqüência. Então, nós temos que deixar sempre isso plantado, para uma cultura não perder, né? Para a cultura não perder, não perder a essência da cultura de quando a gente era pequeno, que os pais da gente era mais pequeno do que nós e os avô, você vê que é uma trajetória longa, mas essa trajetória longa, ela tem que ser cada vez mais aperfeiçoada no passado. Porque o passado, às vezes poderia ter dificuldade, mas não tinha essa facilidade e essa violência que tem hoje.

V- É.

M- Então, hoje, nós estamos vivendo num mundo que nós sabemos qual é a hora que o mundo vai acabar. Qual é a hora que alguém vai embora sem saber o que deixou. Porque cada um plantou aquilo para o futuro. Você vê, hoje, é mãe, filha, filho, treze quatorze ano e você passa por essas experiência, né? Passa por essas experiência de ver a evolução do mundo. Primeiro uma moça só casava com vinte e três anos, vinte e quatro anos, estava preparada, tinha um conhecimento da vida. Hoje é treze ano, quatorze ano, doze ano, dez ano! Aí fala "Não, nós estamos evoluindo." Não, não estamos evoluindo. Nós estaríamos evoluindo se a população estivesse, cada dia mais, se respeitando. Aí nós estaria se evoluindo. Mas não adianta, Vilma, eu não the respeitar nem você me respeitar! Que evolução nós estamos tendo?

V- É.

M- Então nós estamos regredindo. E eu sempre falei, numa palestra aqui, que a desordem pôs a ordem. Então inverteu a letra da bandeira do Brasil.

V-Sei.

M- É “Ordem e Progresso", então agora é "Desordem para o Progresso". 
V- (risos)

M- Não é isso? É "Desordem para o Progresso." Então, eu acho que a gente temo que começar a parar, pensar e ver o que nós vamos fazer. Tanto as esfera maior, que nem as esfera menor. Porque, às vezes, as esfera menor não tem o poder, mas ela sabe fazer. Mas aí tem aquele caso "Não, tem que ter o diploma. Não, tem que ter a faculdade.".

V- É o discurso, né? Deles.

M- É o discurso. Então, eu sempre venho desafiando qualquer diploma, qualquer faculdade. Eu sempre venho desafiando. Por que eu venho desafiando? Que é para dizer para eles que o diploma é um pedaço de papel, é um pedaço de papel, porque o diploma real, mesmo, é esse que estamos vivendo agora.

V- É a vida, né?

M- É isso que nós estamos vivendo. É isso que eu estou passando para você e você vai tentar passar para alguém. Aí você fala "Puxa, mas ele conversou tanto, agora eu vou ver se é o real." Aí você vai dizer "Olha, Miúdo, tal dia eu quero me encontrar contigo na tua casa.", porque aí eu vou te manter de tudo aquilo que, realmente, você vai embasar no seu trabalho, vai colocar e dizer "Olha, eu vi, escrevi. Se alguém tiver dúvida..."

V- Papel está aqui.

M- Está aqui...

V- (risos)

M- A primeira resultado.

V- Claro.

M- Certo?

V- Certo. Mais um pouquinho. Essa associação que você fundou, ainda existe?

M- Existe. 


\section{V- E funciona?}

\section{M- Funciona.}

V- E quantos membros tem?

M- Dos cavaleiros ou dos...

V- As duas

M- As duas. A dos cavaleiros tem quarenta e quatro membro, né? Tem quarenta e quatro membro...

V- Tá.

M- Isso não quer dizer que não tenha mais membro fora da cidade que ainda não está trabalhando e está incluído na associação.

V- Sei.

M- Né? Eles não estão dentro da associação, mas eles são pessoas que estão no mesmo ramo que, amanhã, eles pode estar dentro da associação.

V- Quarenta e quatro que está// Assim, não é associado diretamente, mas está ligado.

M- Mas está ligado.

V- De alguma forma.

M- E qualquer coisa ele vem buscar uma informação. Quando o bicho pega para o lado dele, ele vai recorrer a quem? Quando prende um cavalo "Miúdo, mas prenderam o cavalo em tal lugar" eu digo "Olha, chama o presidente que ele vai buscar o cavalo. "Ah Miúdo, estou com problema." Então tem um ponto de apoio. Só que, por eles não serem educados, não serem colocados numa norma para que eles trabalhassem, eles acham "Ah, isso não vai acontecer não". Então eles acredita // Cidadão só acredita quando a casa cai, quando ele faz a casa num lugar que a árvore está podre e vai cair em cima da casa. "Ah, caiu em cima da minha casa" "Caiu, mas eu te avisei que a árvore ia cair." Então, mas leva tempo para a árvore cair. Às vezes a árvore está podre, mas ela diz ali "Puxa, eu vou cair e vou matar 
uma família, né? Eu vou deixar para cair na hora que não tiver ninguém em casa, deixar para cair na hora que não causar não danos." E a árvore "pou" cai em cima da casa! Quando o cara chega em casa...

V- A casa caiu literalmente.

M- Caiu a casa. Vai reclamar de quê? Então eu sempre cuido antes da casa cair. Lógico, não sou perfeito cem por cento, mas eu tento sempre ser os noventa e nove, porque é uma obrigação que me impede.

V- Claro.

M- Né?

V- E a associação dos criadores?

M- A dos criadores tem...

V- Quantas pessoas, mais ou menos?

M- A dos criadores tinha// tem sessenta e cinco que estava dentro...

V- Sessenta e cinco?

M- Sessenta e cinco, né?

V- Tá, pode ir falando.

M- E se você for fazer a conta, tem mais de cento e cinqüenta, que todos eles cria. (risos) Mas não estão dentro da associação.

V- Mais de cento e cinqüenta que cria?

M- Que cria animal.

V- Que cria animal?

M- Que cria animal.

V- Que tipo de animal?

M- Animal é um bacuri, né? 
V- Que que é bacurim?

M- Bacuri é um porco (risos)

V- Bacurim?

M- Bacuri. O bacuri é o porquinho quando é novinho, né?

V- Ah, um leitãozinho?

M- É um leitãozinho. Então, porque o nome correto é suíno, né?

V-Sim.

M- Então uns chama porco, outro bacuri. Porque a história do Norte é bacuri. No Norte...

V- Eu não conhecia bacuri.

M- Bacuri é no Norte. Aí é o bacuri, é o porquinho novinho, é o leitãozinho, que é chamado de bacurinho. Aí você bota ele no // A gente vendia no Norte, saía vendendo nas feira, né? Aquele porquinho, todo mundo já via e comprava só para fazer a criação, comprava o casalzinho. Sempre vendia o casal, né? Hoje a tradição caiu mais. Mas aí eu chama leitão.

V- É o leitãozinho, né?

M- É o leitãozinho. Mas é o leitãozinho porque é para matar o bichinho...

V- É o bacuri.

M- (?) tua irmã gosta //É para matar o leitão// Tudo sob controle?// Que é para // É o leitão.

V- Entendi. O bacuri. Então eles criam o bacuri? (risos)

M- Cria o bacuri, né? Para justamente criar porca, que aí vem o bacurizinho. (?) tem no sítio, já é uma tradição, tem em vários sítios, o dia em que você vier com folga, eu vou te levar no sítio... 
V- Então, o que eu preciso saber é a quantidade de sítio que tem aqui em Cubatão, mais ou menos, assim por cima. Um dia a gente marca e vem.

M- Porque todos aqui estão...

V- Só para eu pôr no trabalho.

M- Porque aqui, dentro de Cubatão, saíram tudo para São Vicente. Por que saíram para São Vicente?

V- Então, precisamos entender.

M- Porque Cubatão// porque Cubatão, né? Por não ter o local dentro da lei // Tem o local de criar, mas dentro da lei não pode criar. Aí todo mundo saiu.

V- Foi para São Vicente.

M- São Vicente. Então São Vicente, né? Lá para a Pedreira da Mantiqueira, lá para longe, longe do centro.

V- Mas eles se mudaram ou eles mantém esse sítio?

M- Eles mantém lá.

V- Como é que é?

M- Eles mantém lá, porque lá eles pode...

V- E eles vão para lá?

M- Eles vão para lá. Fim de semana eles estão lá.

V- E durante a semana, quem cuida?

M- Eles também. Porque o situante sempre ele já veve lá.

V- Tá.

M- Tem um caseiro, ele mantém alguém.

V- E assim, o que você poderia me dizer daqui de Cubatão mesmo? 
M- Dentro do centro da cidade não tem (?), né?

V- Não, assim, por exemplo, Areais...

M- No Areais tinha a Rosa, foi intimada a tirar todos os bichos do sítio (risos)

V- Então, esse tal problema com a Rosa (risos). Por exemplo, Pilões, Cota, Vila Esperança, Vila Natal, Vila Noel que eu falei com...

M- Isso.

V- O seu Wilson, né? Que está lá na Cosipa e também mora aqui.

M- Isso, é.

V- Que mais? Ali nos Queirozes, né?

M- Tudo ali no Queiróz era uma criação...

V- Vila dos Pescadores, tem até a// estende até para Santos a Alemoa, né?

M- É.

V- Tem a Vila dos Pescadores // dos Criadores.

M- Dos Criadores.

V- Então, você pensando, assim, com todo esse pessoal que você tem contato daqui de Cubatão, fora, assim, do Vale Verde para lá. Quantas pessoas você acha, mais ou menos, que tem terra, assim, que cria? Você sabe dizer, por cima?

M- Aqui? Não, aqui no eixo de Cubatão ninguém mais cria.

V- Ninguém?

M- Ninguém.

V- Mas...

M- Por que não pode criar? Tem o Severino que, de vez em quando (?) uns ali escondido, de vez em quando a vigilância entrava ali, e tira foto. Porque todos foram intimados a abandonar o seu município e os seus sítio. 
V- Sei.

M- Então, às vezes, encontrava num fim de semana um escondido. Porque todo eles tinha...

V- Porque a Rosa falou para mim que tinha bastante gente. Ela ainda falou "Olha, procura o Miúdo, fala com ele"

M- É, mas é que fica tudo escondido...

V- Está escondido? O que tem está escondido? Eu respeito, assim, que você não me revele nada...

M- Justamente, porque...

V- Mesmo porque o que fica aqui, é para uso// né?

M- Não, mas veja bem, eu digo está escondido está a vista, porque, de vez em quando aparece uma denúncia. Mas nós temos na Água Fria, né? Nós temos aqui na Vila Esperança. Ainda tem aquela pessoa que gosta de criar o seu, ele não está criando mais em quantidade daquilo que ele queria criar.

V- Muitos saiu, mas tem uns que criam e...

M- É lógico, mas está criando aqueles um, dois, para ele pelo menos ter um entretanto dele, né? Ele ter o entretanto dele.

V- Tá.

M- Por que a finalidade é o que? É, justamente, é a cultura dele.

V- É.

M- E a cultura dele, ele pode não criar // Ele queria criar cem, mas ele falou "Não, vou criar um."

V- Mas esse pessoal vive disso? Ou tem algum trabalho?

M- É um hobbie.

V- É um hobbie? 
M- É, uns vive e outros não, né? Porque, que nem a Rosa tem bastante bicho, mas ela vê, é funcionária pública, trabalha na prefeitura...

V- Sei.

M- Ela gosta. Não, ela construiu uma casa para o cavalo.

V- (risos)

M- Ela construiu uma casa para $0 .$.

V- O He-Man

M- Entendeu? Ela comprou uma casa para o cavalo. Você dê uma pisa nela, mas não encoste a mão no cavalo dela!

V- Claro. Sei.

M- É um hobbie dela! Né? Então, cada um tem o seu hobbie. E aquilo que o cidadão tem como hobbie, desde que ele seja bom, poxa, por que não deixar ele, né? Então vamos criar uma área para que ele tenha aquilo. Você vê o Bill, o seu // Lá no Capivari, né? Você vê a situação que ele vive ali. Ali era para ser uma área servindo, justamente, para quê? O pai do Luís, Luís sabe ferrar os cavalos, o único ferrador aqui em Cubatão é ele, é o Luís.

V- Eu sei. E ele ferra bem, né? Que vem gente de fora procurar ele.

M- De tudo quanto é lugar! Então ele mesmo constrói a ferradura, ele mesmo faz a ferradura.

V- É mesmo? Nossa, eu conversei, conversei com ele, pensei que ele só ferrasse, ele faz?

M- Não, ele faz a ferradura.

V- Nossa, é bom, né?

M- Você está entendendo? Então veja só, você vai lá na Vila dos Criador, tem lá a turma. Dia de domingo eles se junta lá com os cavalo, as criança. Aí eles vão lá, né? 
Fazer aquela brincadeira, correr uma cavaiada, correr uma prova de tambor. É coisinhas pequena, mas é coisas pequena que eles se alegram.

V- Sei. E para o Perequê, o pessoal vai?

M- Vai, mas quando vai para o Perequê aí tem aquele problema ambiental.

V- Ah!

M- Né? Porque tudo é ambiental. Agora não sabe que o cavalo, ele vive de capim.

V- E é esterco.

M- E é o esterco.

V- Que depois vira esterco, né?

M- Entendeu? Então daria para criar ali um parque, né? Uma coisa organizada. Como é que se cria uma coisa organizada? Para ter tudo dentro dos padrão, organização.

V- Tá.

M- Aí eles // Porque se você chama eles para se organizar e determina, a lei determina, eles se organiza. Agora, se a lei não determina que eles se organizem e tenha o acesso, eles vão se organizar para quê? Olha, você está com o seu carro, é um exemplo, é um carro por cavalo. Agora, se o seu carro está emplacado e tem um dono, ele pode roubar. Então o cavalo, cria-se um horário, não de pique, mas para eles passearem. O local adonde quiserem ir.

V- É, eles reclamam que o cavalo faz sujeira, não sei o quê...

M- Ah, mas quem reclama que o cavalo faz sujeira, mas já viveu dentro de uma cocheira!

V- (risos) É, verdade.

M- Quem disser que o cavalo faz sujeira, ele já viveu dentro de uma cocheira, porque qual é o ser humano que não passou por uma cocheira? Que não foi lá ver um animal? Quer dizer que você vai ver porque é bonito? Não, você vai ver porque 
você gosta! Porque aquilo que você não gosta, não vai ver. Você vai? Não gosto, não vou ver.

V- Pode ser bonito, mas se você não gosta...

M- Não gosta, você não vai ver.

V- Certo.

M- E aquilo que você nunca nem teve contato, mas você, algo que tem dentro de você puxou, olha "Bota um rodeio aí". Você não vai (?) "Vou, vou lá ver" Por que você vai ver? Porque alguém do teu antepassado deixou no teu sangue que tu tinha que está ali vendo como é que monta num cavalo, como é que tira leite de uma vaca, como é que faz o queijo. Alguém do teu sangue, que ninguém sabe a idade dos ano, deixou cravado que vem passando de sangue em sangue.

V- É.

M- Às vezes você tem só uma gotinha "Ah, eu não gosto do cheiro da galinha" Mas puxa, será que ninguém da sua família nem nunca comeu uma galinha caipira? (risos) E ela é saborosa, o sabor é diferente.

V- Claro, nossa, imagina, totalmente diferente.

M- Agora, como ela é criada é que precisa ser educado. Como ele vai ser criado, é para, justamente, você ter como é criado. Olha, eu tenho lá sete pato. Eu cheguei a ter quase duzentos pato e pata.

V- É?

M- É. Tu acha que sete pato me dá lucro? Não dá. Mas eu tenho que ter ali, eles corre, tem um lá que corre atrás das mulher. Corre atrás das menina.

V- (risos)

M- Ele corre atrás das menina. Tem mulher que não entra lá, com medo do pato.

V- Com medo? Medo dele? Mas é marreco, não é ganso...

M- Meus meninos // meus neto pega ele pelo pescoço. E gente adulto não entra lá... 


\section{V- Com medo de pato.}

M- "O pato vai me pegar" eu digo "Vai lá" Os meus netinho, o Kevin, a Tainá e a Evelin, "Vai lá meu filho, traz lá o pato para o vô". Eles vão lá, pega o pato pela asa, os três...

V- Nossa! Que é o contato que tem, né? Você vê? Desmistifica o negócio.

M- Você está entendendo?

V- Estou.

M- Aí agora, se você for lá, agora a pouco tempo, você vai ler lá. Tinha uma caixa lá no meio do mato, que eu tenho um terreno grande, eles ficam brincando dentro do capim. Eles vão lá para dentro do capim e ficam brincando, a molecada. Às vezes eu falam “ Mas Miúdo e se uma cobra devorar?” Se a cobra morder é porque a natureza mandou ela morder. Uma coisa é estar dentro de casa, a cobra vai morder. "Mas pode? Tu é doido?" Não, eles estão se criando aí, que nem eu fui criado, eles vão lá dentro do capim, brinca dentro do capim. Eu deixei um lugar para eles ter contato com o verde, ter contato com a terra.

V- Está certo.

M- Aí a pata foi lá. Ih, eu tampei lá e deixei lá, né? Mas menino, você sabe, menino ele é curioso. E ela foi lá "Vem cá" $E$ vinha aquela festa "Vô, vem ver o que foi que aconteceu!" "Que foi que aconteceu, que foi, meu filho?" Cheguemos lá, estava lá a pata tinha tirado os patinho.

V- Ah, que bonitinho!

M- Tudo amarelinho! "Olha, vô, o patinho!" "Ah, vamos tirar daqui! Vamos guardar os patinho!Vamos cuidar dos patinho para não morrer!" Então eles já sabem que tem que cuidar dos patinho para não morrer! Aí pus lá na luz, chega lá eles nem agüenta na caixa para ver. Tem uma luz, está lá se criando; tirou doze, estava se criando os doze!

V- Doze? Olha, que... 
M- Eu separei da pata, porque se eu deixar eles com a pata, eles morrem! Porque ele é sensível. Botei lá (?) da ração.Você acha que a ração que eles já comeram não está mais cara do que os patinho vale?

\section{V- Claro.}

M- Mas é só, pelo menos, para eu ter o prazer de, justamente, eles está vendo, tenho o prazer de eles estar ali olhando. (?) De vez em quando, aí arrumei uma nora, né? Que agora eu tenho uma nora, ela "Mas esses patos só caga..." "Minha filha, pelo menos você está pisando na// na bosta do pato!" Aí agora ela parou, acostumou! Aí ela vai lá, sobra de comida ela bota para os patos, né?

V- É o contato que falta para as pessoas, né?

M- É o contato que falta para as pessoas. Então, esta é a nossa essência. E eu parei de criar porco que os vizinho começava a entregar. Aí começava "Ah, o porco está fedendo." Mas quando eu matava o porco e começava a fazer a tripa do porco assada, sabe? O filé, o toucinho, começava a fumaçar...

V- Um chouriço!

M- Eu cheguei a dar cinqüenta quilos de carne por final de semana. Dar para a comunidade, assim. Cinqüenta quilos, um porco praticamente. Então, chegava final de semana, eu te mostro lá, eu matava quinze, vinte porco.

V-É mesmo?

M- Sexta, sábado e domingo.

V- Quinze, vinte porco? Porcos para o...

M- Por dia! Por dia!

V- Por dia?

M- Por dia! Eu te mostro tudo num caderno lá. Por quê? Porque era tudo coisa boa, o povo vinha de tudo quanto era lugar para comprar. Comprava para levar para a festa. Você vai fazer uma festa, aí nós vamos pegar aí mil reais e vou comprar de carne. Não, você vai lá com trezentos reais você compra um porco aí, compra um 
cabrito. Você mata, faz a buchada, faz o sarapatel faz tudo o que você quiser fazer e distribui para a sua comunidade comer, para a sua festa. Então, são coisas que a gente temos que fazer o quê? Simplesmente só botar o povo no contato.

V- E já tem raiz, né? Tudo...

M- E já tem raiz. Por mais que você queira sair, já pensou se eu tivesse esquecido de como eu vim do Norte?

V- (risos)

M- Se eu tivesse esquecido o que eu passei no Norte? O sofrimento, que hoje eu falo para o filho "Olha filho, tanto faz ter caviar, que nem ter rapadura. É o mesmo gosto, o sabor é o mesmo." Você gosta de caviar? Gosta. Então, deixo você cinco dias sem comer e dê um pão com uma rapadura ou um pouco de farinha, para ver se não vai ser melhor do que o caviar.

V- Claro. Tudo uma questão de...

M- Tudo uma questão de você estar na essência da sua cultura. Eu tenho // dos seis filhos, só um, o caçula que só gosta de peito de frango, só gosta de asa de frango, não gosta de asa, não gosta de pé, né? O negócio dele é o peito do frango. Deixa você sem comprar peito de frango umas duas semana. Aí ele vai começar a comer o pé, o pescoço (risos)

V- Funcionou?

M- Mas, hoje ele não pode ver um pé, não pode ver um um pescoço. Porque ele não...

V- Educou o paladar dele, né? (risos)

M- Porque tem que educar!

V- Claro!

M- Que as pessoa acha que só a vitamina está no peito do frango. Não, a vitamina está no osso!

V- O pé é uma iguaria na China, eles importam, no Japão. 
M- É.

V- Cartilagem é riquíssimo aquilo, nossa!

M- Você pega aquilo ali, bota uma batata, bota um coentro, bota um tomate...

V- Faz um // Minha mãe uma vez fez uma pezada, sabe? Uma panela de pressão cheia de pé no molho. Nossa, não sobrou um!

M- Você come à vontade e você vai se entreter que às vezes você come a comida e fica lá (?)

V- Sim.

M- E então, tudo isso tem os haver, das pessoas entenderem o que é uma cultura, o que é a história de um povo e a raiz nossa, que nós temos sempre que estar cultivando.

\section{FIM DA FITA}

